Beatriz Gallotti Mamigonian Joseane Zimmermann Vidal

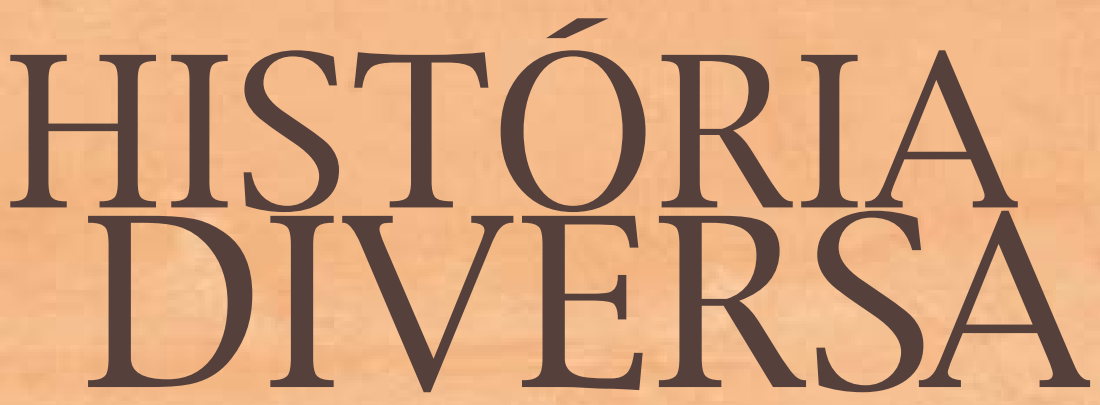

AFRICANOS E

AFRODESCENDENTES

NA ILHA DE SANTA CATARINA 


\section{História diversa: africanos e afrodescendentes na Itha de Santa Catarina}


UNIVERSIDADE FEDERAL DE SANTA CATARINA

Reitor

Ubaldo Cesar Balthazar

Vice-Reitora

Catia Regina Silva de Carvalho Pinto

EDITORA DA UFSC

Diretora Executiva Interina

Flavia Vicenzi

Conselho Editorial

Agripa Faria Alexandre

Antonio de Pádua Carobrez

Carolina Fernandes da Silva

Evelyn Winter da Silva

Fábio Augusto Morales Soares

Fernando Luís Peixoto

Ione Ribeiro Valle

Jeferson de Lima Tomazelli

Josimari Telino de Lacerda

Luis Alberto Gómez

Marília de Nardin Budó

Núbia Carelli Pereira de Avelar

Priscila de Oliveira Moraes

Sandro Braga

Vanessa Aparecida Alves de Lima

\section{Editora da UFSC}

Campus Universitário - Trindade

88040-900 - Florianópolis-SC

Fone: (48) 3721-9408

editora@contato.ufsc.br

www.editora.ufsc.br 


\author{
Beatriz Gallotti Mamigonian \\ Joseane Zimmermann Vidal \\ Organização
}

\title{
História diversa: africanos e afrodescendentes na Ilha de Santa Catarina
}


(C) 2021 (e-book) Editora da UFSC [Nota do Editor = mesmo conteúdo]

(C) 2013 (impresso)

Coordenação editorial:

Cristiano Tarouco

Capa:

Maria Lúcia Iaczinski

Editoração:

Paulo Roberto da Silva

Revisão:

Marília Mezzomo Rodrigues

Mapas:

Míriam Karla Machado

Imagem de capa: detalhe de Vista parcial da cidade de Nossa Senhora do Desterro c.1851, de Victor Meirelles, do acervo do Museu Victor Meirelles/IBRAM/MinC

Catalogação na fonte pela Biblioteca Universitária da Universidade Federal de Santa Catarina

H673 História diversa [recurso eletrônico] : africanos e afrodescendentes na Ilha de Santa Catarina / organização Beatriz Gallotti Mamigonian, Joseane Zimmermann Vidal. - Florianópolis : Editora da UFSC, 2021. 271 p. : il.

E-book (PDF)

Disponível em: https://doi.org/10.5007/978-65-5805-047-6

ISBN 978-65-5805-047-6

1. Negros - História. 2. Afrodescendentes - Florianópolis (SC). I. Mamigonian, Beatriz Gallotti. II. Vidal, Joseane Zimmermann.

CDU: 981.640 .602

Ficha catalográfica elaborada por Fabrício Silva Assumpção - CRB-14/1673

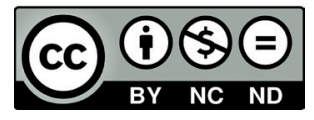

Este livro está sob a licença Creative Commons, que segue o princípio do acesso público à informação. O livro pode ser compartilhado desde que atribuídos os devidos créditos de autoria. Não é permitida nenhuma forma de alteração ou a sua utilização para fins comerciais.

br.creativecommons.org 


\section{Sumário}

|| Introdução || Uma história diversa de Florianópolis .................. 8

Beatriz Gallotti Mamigonian

Joseane Zimmermann Vidal

|| Capítulo 1 || Tráfico de escravos e a presença africana na Itha de Santa Catarina ................................. 16

Beatriz Gallotti Mamigonian

Vitor Hugo Bastos Cardoso

|| Capítulo 2 || Armação baleeira da Lagoinha: uma grande unidade escravista

Fernanda Zimmermann

|| Capítulo 3 || Escravidão nos engenhos de farinha da Lagoa da Conceição ....................................6 67

Ana Carla Bastos

|| Capítulo 4 || A Irmandade do Rosário e seus irmãos africanos, crioulos e pardos .............................. 83

Claudia Mortari Malavota

|| Capítulo 5 || Entre a diversão e as proibições: as festas de escravos e libertos na Ilha de Santa Catarina.... 106 Jaime José dos Santos Silva

|| Capítulo 6 || Quilombos e fugas de escravos na Itha de Santa Catarina

Martha Rebelatto

|| Capítulo 7 || Africanos e descendentes na história do primeiro mercado público de Desterro ....... 147

Fabiane Popinigis 
|| Capítulo 8 || Victorino de Menezes: um comerciante de escravos em Desterro

Rafael da Cunha Scheffer

|| Capítulo 9 || Da escravidão à liberdade na Itha de Santa Catarina

Henrique Espada Lima

|| Capítulo 10 || Cruz e Sousa: de Desterro para o panteão da poesia simbolista

Elizabete Maria Espíndola

|| Capítulo 11 || Patápio Silva: trajetória do flautista interrompida em Florianópolis

Maurício Oliveira

|| Capítulo 12 || Clubes e associações de afrodescendentes

na Florianópolis das décadas de 1930 e 1940 .. 254

Maria das Graças Maria

Autores e organizadoras 


\section{Listas}

\section{Figuras}

Figura 3.1 - Batismos de africanos novos por ano na Freguesia da Lagoa (1808-1842).

Figura 5.1 - Uma festa negra na Ilha de Santa Catarina (1803). W. G. von Tilesius

\section{Mapas}

Mapa 1 - Ilha de Santa Catarina e litoral adjacente no século XIX ...................15

Mapa 2 - Localização das armações baleeiras no litoral catarinense 45

\section{Quadro}

Quadro 4.1 - Cargos da Irmandade de Nossa Senhora do Rosário 88

\section{Tabelas}

Tabela 2.1 - Lista nominal dos escravos da Armação da Lagoinha em 1816..... 49

Tabela 2.2 - Lista de escravos batizados em 1817 como pertencentes ao Contrato da Armação da Lagoinha.

Tabela 2.3 - Filhos de escravos da Armação da Lagoinha batizados na Freguesia do Ribeirão (1818-1839)

Tabela 2.4 - Habitantes da Armação da Lagoinha em 1843. 65

Tabela 2.5 - Distribuição da população do Ribeirão da Ilha conforme posição nos fogos (1843).

Tabela 2.6 - Posse escrava no Ribeirão da Ilha (1843). 66 


\section{|| Introdução ||}

\section{Uma história diversa de Florianópolis}

Beatriz Gallotti Mamigonian Joseane Zimmermann Vidal

De uma cidade, não aproveitamos as suas sete ou setenta e sete maravilhas, mas a resposta que dá às nossas perguntas. Ítalo Calvino, Cidades Invisiveis.

Desterro, 12 de abril de 1831. Os integrantes da comissão encarregada de visitar prisões civis e militares e estabelecimentos públicos de caridade visitaram a cadeia pública da cidade e encontraram as celas de presos civis com as paredes escurecidas, o que lhes deu impressão de pouco asseio. $\mathrm{Na}$ cela dos presos civis havia cinco detidos. Entre eles, Manoel dos Passos Magalhães, registrado como "preto liberto", preso por ofensa e que, por "falta de proteção para promover seu livramento", não tinha esperança de soltura. Outro, Joaquim Correa, preso como escravo fugitivo, se dizia liberto; nascera na Ilha de São Tomé, no meio do Atlântico, e infelizmente não deixou testemunho das andanças e navegações que o trouxeram a Desterro. Talvez fosse marinheiro. Os dois reclamavam de não ter recursos para custear seu pedido de relaxamento da prisão. A cela das mulheres estava desocupada naquela ocasião, mas também tinha as paredes escurecidas pela fumaça, o que, associado à falta de luz, tornava o ambiente tenebroso, na avaliação dos membros da comissão. ${ }^{1}$

1 ARQUIVO HISTÓRICO MUNICIPAL DE FLORIANÓPOLIS (doravante AHMF). Registro Geral da Câmara Municipal de Desterro (1830-1831). Relatório da Comissão para visita das prisões civis, 
A notícia das manifestações populares e conflitos antilusitanos no Rio de Janeiro, que resultaram na abdicação de Dom Pedro I, em 7 de abril, não tinha chegado a Desterro ainda. Quando chegou, no dia 20, a Câmara externou todo o júbilo pela "feliz revolução heroicamente consumada na Capital do Império", chamando os portugueses de "ingratos hóspedes e pseudo-brasileiros". ${ }^{2}$ Houve Te Deum na Igreja Matriz, encomendado pelo presidente da província. A Câmara também organizou comemorações públicas do evento, ordenou que os cidadãos iluminassem a frente das casas por três dias, a contar do dia 20, e autorizou manifestações públicas de júbilo, recomendando, porém, a moderação "que tanto caracteriza a nossa briosa nação". No dia 22, a Câmara promoveu e sediou uma reunião para a qual convidou o presidente da província e todos os cidadãos que quisessem partilhar da alegria pelo evento; para evitar "tumulto de pretos ou outra qualquer desordem", pediu ao presidente uma guarda de 30 homens do 8 Batalhão para a vigilância. Devia temer ajuntamento de escravos e libertos. Aparentemente, não foi deles que partiu o tumulto, mas dos próprios membros do 8o Batalhão, que, com os soldados de outros batalhões estacionados na cidade, na hora marcada para a festa na Câmara, pediram a deposição do presidente da província e comandante de armas. Este, o chefe de esquadra Miguel de Sousa Mello e Alvim, não teve alternativa senão renunciar. A situação continuou instável por mais um tempo; em abril de 1831, a presidência da província devia onze meses de pagamento à tropa. ${ }^{3}$

Os presos devem ter acompanhado aqueles eventos através das grades da cela, ouvindo os gritos da tropa pela deposição do representante de D. Pedro I, ou ainda pelas conversas dos que vinham da rua, já que a cadeia ficava no térreo do próprio prédio da Câmara. Talvez cogitassem que lado tomar nos conflitos que opunham brasileiros a portugueses. Talvez acreditassem que "o amor da liberdade", tão propalado naqueles dias, pudesse inspirar sentimentos de piedade ou justiça em algum cidadão que os ajudasse a sair da prisão. A situação deles era tão miserável, que viviam

militares e eclesiásticas e de todos os estabelecimentos públicos de caridade. Fls. 79v. a 82.

2 AHMF. Registro Geral da Câmara Municipal de Desterro (1830-1831), fls. 73-73v. As manifestações da Câmara em torno da abdicação estão entre as folhas 70 e $74 \mathrm{v}$.

3 A ABRILADA em Santa Catarina. Revista Trimestral do Instituto Histórico e Geográfico de Santa Catarina, v. 7 (2o trimestre de 1918), 159-164; CABRAL, 1972a, p. 11-13. 
das esmolas de passantes para se alimentar, pois não recebiam comida na cadeia. Manoel Guimarães, o preto liberto, estava preso havia quase um ano e meio, e Joaquim Corrêa, de São Tomé, havia alguns meses. Faziam da cela sua moradia, em resumo. Os membros da comissão indicada pela Câmara para verificar as condições de salubridade nas prisões encontraram a cela "varrida e sem imundícies", mas cheia de fumaça que escurecia as paredes. Vinha de um fogo que os presos mantinham sempre aceso. Quando a comissão sugeriu que o fogo fosse extinto, os presos reclamaram. Alegaram que era necessário para cozinhar.

Vários relatos da história de Florianópolis mencionam a presença de escravos ou libertos, entretanto, geralmente aparecem como a mão de obra responsável pela construção dos prédios mais antigos ou em histórias pitorescas, como as do trabalho das lavadeiras nos rios e córregos da cidade ou do transporte de água potável e dejetos das casas. Quando não são mão de obra do passado ou protagonistas de situações pitorescas, os indivíduos de origem africana não figuram na história da cidade no século XIX. Os exemplos seriam muitos. Experimente você lembrar-se de alguns livros que leu sobre Florianópolis ou folhear alguns deles. Protagonistas negros são raros, vai concordar. O motivo disso é que Florianópolis, há bastante tempo, tem sido vista e interpretada como terra de "tradições açorianas", e o estado de Santa Catarina como próspero graças à fixação de europeus. A economia catarinense antes da fundação das colônias de Blumenau e Joinville é tida como insignificante, e assim, o auge da escravidão no litoral catarinense e na Ilha de Santa Catarina não tem recebido muita atenção até agora. Neste livro, trazemos elementos para formar outra imagem da história da cidade, entre os séculos XIX e XX. Uma história diversa. Diversa em todos os sentidos que a palavra possui: diversa porque diferente da história contada até agora; diversa porque múltipla e porque expõe a diversidade; diversa porque está mudada; e ainda, diversa porque é discordante.

A "invisibilidade" da presença de africanos e descendentes na memória histórica não é prerrogativa de Santa Catarina; ocorre nos outros estados da região Sul e em vários países das Américas que receberam contingente significativo de africanos, mas que construíram memórias e identidades nacionais associadas a indígenas e europeus, ou nelas enfatizaram a mestiçagem. A Argentina é um exemplo. Apagou-se 
da memória a forte presença de africanos em Buenos Aires, e em algumas províncias, até o início do século XIX, não havendo lugar para seus descendentes na identidade nacional hoje.

Apontar a presença de africanos e seus descendentes - fossem escravos, libertos ou livres - cumpre o papel de devolver visibilidade a esses grupos no passado e, evidentemente, no presente. Mas esta coletânea resulta de uma preocupação em ir além da denúncia da invisibilidade e da demonstração da presença de africanos e afrodescendentes no passado. Ancorados na História Social e baseados na pesquisa em documentos de arquivo muitas vezes inéditos, os capítulos aqui reunidos inserem Santa Catarina na história do Atlântico Negro, uma história partilhada por habitantes da Europa, das Américas e da África, que enfatiza o protagonismo dos africanos e seus descendentes na formação do Novo Mundo. Nessa história, o comércio transatlântico de escravos é não apenas o mecanismo de fornecimento de mão de obra para as unidades produtivas nas Américas, mas também a migração forçada, que deslocou populações no interior do continente africano, dispersou aproximadamente doze milhões de pessoas através do Atlântico e alimentou a escravidão, deixando um legado de discriminação racial. A história compartilhada do Atlântico negro aborda as transformações culturais, resistências e lutas das populações de origem africana contra a escravização, a exploração, o racismo e outras formas de opressão. Nessa história, os territórios da diáspora africana estão conectados.

Como se dava o tráfico de escravos para Santa Catarina? De onde vieram os africanos que aqui viveram como escravos e libertos? Em quais atividades econômicas foram empregados? Como era o cotidiano de trabalho nessa região de propriedades pequenas? Como se dava a relação com os senhores, e quais as formas de resistência adotadas pelos escravos? Que espaços os africanos e seus descendentes criaram para suas manifestações culturais? Quais as chances de alforria e oportunidades de trabalho na liberdade? Como era a vida das pessoas "livres de cor", e como se manifestava a discriminação, antes e depois da Abolição? Essas são algumas perguntas respondidas ao longo do livro.

Não se trata, como se vê, de acrescentar a "contribuição" de um "grupo étnico" à cultura florianopolitana ou catarinense, como se houvesse uma cultura essencialmente afrocatarinense, homogênea e 
atemporal. Ou como se algumas identidades étnicas forjadas no século $\mathrm{XX}$ dessem conta da pluralidade de práticas culturais dos habitantes do território que veio a constituir Santa Catarina. Ninguém pode abrir mão de pensar historicamente, de se preocupar com os processos, embates cotidianos e jogos de poder que envolveram sujeitos de diversas origens e culturas e resultaram na sociedade e no espaço que conhecemos. Trata-se, portanto, de reconhecer que a história da experiência africana deve ser integrada à história de Florianópolis e de Santa Catarina, não um simples capítulo dela. Trata-se, ainda e acima de tudo, de situar Santa Catarina no Atlântico negro e permitir enxergar "a flor na senzala". Essa expressão, consagrada por Robert Slenes, remete à interpretação de símbolos e significados desconhecidos ou opacos para aqueles que partilhavam a visão de mundo dos senhores de escravos e caracteriza uma releitura das ações de africanos e seus descendentes sob a escravidão, além do reconhecimento de que tinham tanto esperanças quanto recordações. ${ }^{4}$

Os membros da comissão, indicada pela Câmara, que visitaram as celas da cadeia pública de Desterro e reclamaram das paredes enegrecidas pela fumaça ignoravam (ou não procuravam saber) o significado que os presos atribuíam ao fogo, que mantinham sempre aceso. Enxergar "a flor na senzala", ou nesse caso, nas enxovias da cadeia pública, implica se perguntar sobre as trajetórias que trouxeram Manoel Guimarães e Joaquim Corrêa à Ilha de Santa Catarina, suas experiências entre a escravidão e a liberdade, e considerar que, provavelmente reproduziam e ressignificavam, do lado de cá do Atlântico, tradições ancestrais de muitos povos africanos, notadamente da África Centro-Ocidental, que consideravam o fogo um elemento sagrado, a proteger os integrantes da família e seus ancestrais contra todos os males. Mesmo sem termos certeza de que Manoel Guimarães e Joaquim Corrêa provinham de região ou grupos de tradição ovimbundu ou bakongo, é plausível supor que aqui no Brasil tivessem se familiarizado com suas práticas. Além de aquecer, secar o ambiente úmido e afastar insetos, os dois africanos provavelmente investiam significado sagrado àquele fogo aceso na cela, pois os ajudava a enfrentar as adversidades. Talvez os unisse naquele momento de polarização entre brasileiros e portugueses; talvez suscitasse a solidariedade de outros africanos residentes na cidade. São hipóteses

4 SLENES, 1999. 
para as quais ainda não temos provas, mas é importante levantá-las. Só assim, personagens como Manoel Guimarães e Joaquim Corrêa deixam de ser figuras pitorescas, ilustrações de como o passado era "exótico". Também dessa forma, figuras como eles superam a condição de vítimas à qual costumam ser relegadas nos discursos de denúncia da invisibilidade. Nesta coletânea, africanos e seus descendentes, fossem escravos, libertos ou livres, são tratados como protagonistas da história, pessoas que sobreviveram aos horrores da travessia atlântica e da escravidão e enfrentaram a opressão como melhor puderam, fizeram escolhas diferentes e, mesmo sem formar um grupo coeso, deixaram marcas na constituição da sociedade em que viveram.

Convidamos você, leitor, seja catarinense nato ou adotado, visitante ou amante da Ilha de Santa Catarina, a percorrer os capítulos desse livro. Venha com os olhos abertos para revisitar velhos episódios e encontrar novos sujeitos; com os ouvidos prontos para ouvir velhos sons, mas experimentar novas sensações; e com disposição para conhecer e reconhecer a participação dos africanos e seus descendentes na construção de Santa Catarina, sujeitos até então invisíveis na história que é de todos nós.

\section{Referências}

CABRAL, Oswaldo Rodrigues. Nossa Senhora do Desterro: memória. v. 1 e 2. Florianópolis: Ed. do Autor, 1972a. 1972b.

. Nossa Senhora do Desterro: Notícia. v. 1 e 2. Florianópolis: Ed. do Autor,

CARDOSO, Fernando Henrique; IANNI, Octávio. Cor e mobilidade social em Florianópolis. São Paulo: Companhia Editora Nacional, 1960.

CARDOSO, Paulino J. F.; MORTARI, Cláudia. Territórios negros em Florianópolis. In: BRANCHER, Ana (Org.). História de Santa Catarina - Estudos Contemporâneos. Florianópolis: Letras Contemporâneas, 1999.

CORRÊA, Carlos Humberto P. História de Florianópolis - Ilustrada. 3. ed. Florianópolis: Insular, 2005.

GILROY, Paul. O Atlântico negro - modernidade e dupla consciência. Rio de Janeiro: Editora 34/UCAM - Centro de Estudos Afro-Asiáticos, 2002.

LEITE, Ilka Boaventura (Org.). Negros no sul do Brasil: invisibilidade e territorialidade. Florianópolis: Letras Contemporâneas, 1996. 
14 MAMIGONIAN, Beatriz G.; RACINE, Karen. People in the Making of the Black Atlantic. In: The Human Tradition in the Black Atlantic; 1500-2000. Lanham, MD: Rowman and Littlefield, 2010, p. 1-8.

PEDRO, Joana Maria et al. Negro em terra de branco: escravidão e preconceito em Santa Catarina no século XIX. Porto Alegre: Mercado Aberto, 1988.

PIAZZA, Walter F. A escravidão negra numa província periférica. Florianópolis: Garapuvu/Unisul, 1999.

SLENES, Robert W. Na senzala, uma flor: esperanças e recordações na formação da família escrava; Brasil Sudeste, século XIX. Rio de Janeiro: Nova Fronteira, 1999.

VEIGA, Eliane Veras da. Florianópolis: memória urbana. Florianópolis: Editora da UFSC/Fundação Franklin Cascaes, 1993. 
Mapa 1 - Ilha de Santa Catarina e litoral adjacente no século XIX

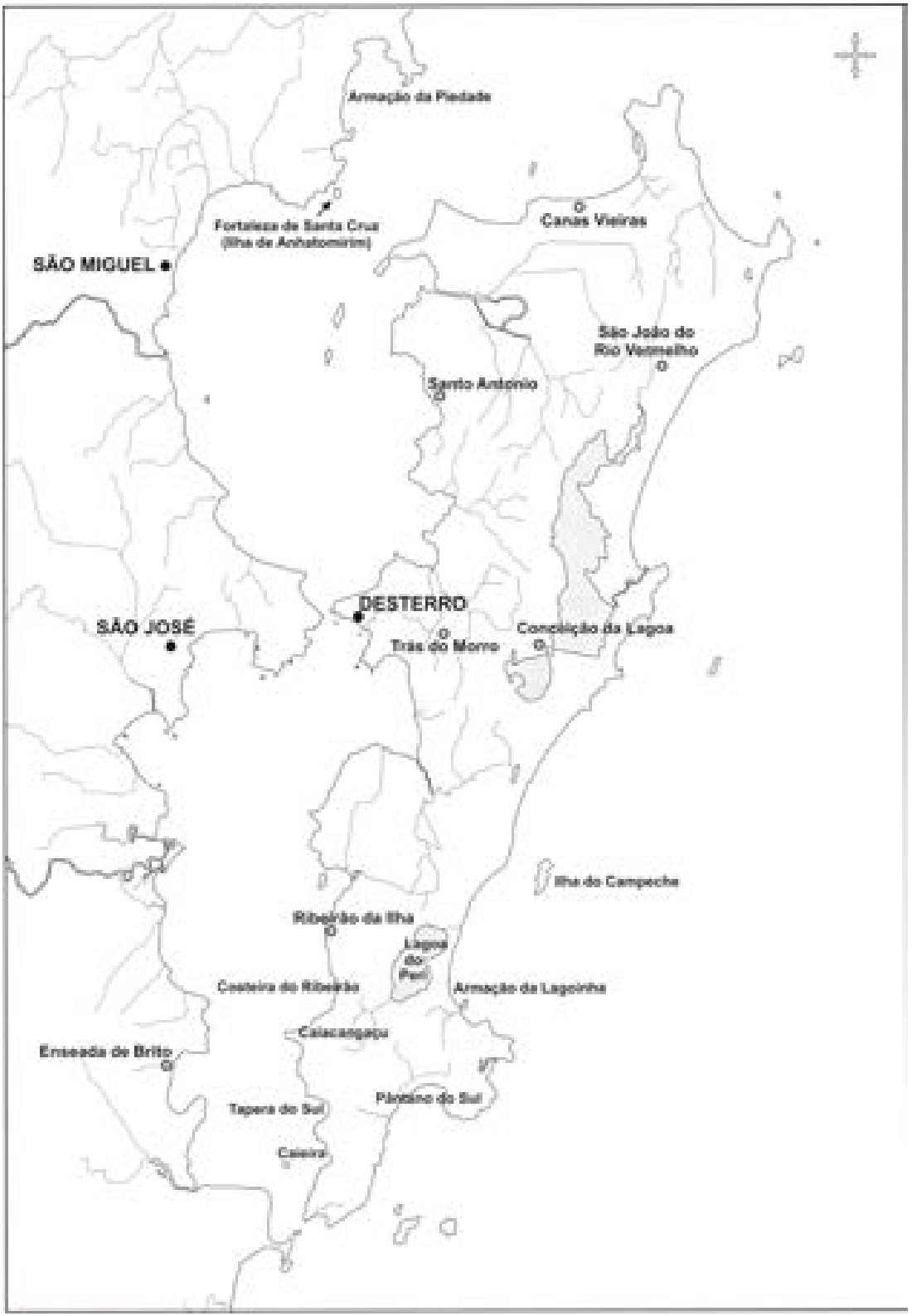




\section{|| Capítulo 1 ||}

\section{Tráfico de escravos e a presença africana na Ilha de Santa Catarina}

Beatriz Gallotti Mamigonian

Vitor Hugo Bastos Cardoso

No dia cinco de fevereiro de 1811, pelos caminhos que davam acesso ao largo da Matriz da Vila de Nossa Senhora do Desterro, três corpos de jovens africanos foram levados para o cemitério da igreja matriz, a fim de serem inumados. O padre coadjutor Joaquim Santana Campos provavelmente já estava acostumado à triste cena. Nos últimos anos, já tinha visto casos como aquele se repetirem quase diariamente. A cada ano, crescia o número de africanos que morriam na cruel condição de escravos recém-chegados à Ilha de Santa Catarina.

Os três escravos que faleceram naquele dia pertenciam ao capitão José Luís do Livramento, uma das figuras mais ilustres da sociedade desterrense. No dia seguinte, outros três corpos, também de cativos de José do Livramento, foram inumados no mesmo cemitério. Em um curto período de dois dias, este senhor já havia mandado sepultar seis escravos africanos, todos eles "boçais", isto é, recém-chegados da África e ainda nem sequer adaptados à vida no Brasil. Ao que tudo indica, esses africanos faziam parte de uma leva de escravos adquiridos no circuito regional do tráfico negreiro. Tinham feito a temível e sofrida travessia atlântica há pouco e aportado no Rio de Janeiro, o maior porto de desembarque de cativos da América.

A partir dos assentos assinados pelo padre Joaquim Campos, no primeiro Livro de Óbitos de Escravos da Paróquia de Desterro, sabemos 
que os escravos foram identificados como pretos "da Costa", um termo que provavelmente foi julgado suficiente para fazer referência à origem africana dos mortos - ou, como a própria expressão sugere, para informar que vieram da costa da África. Em verdade, o termo nada nos diz sobre a real procedência ou o grupo étnico dos africanos em seu continente de origem, indicando a desinformação e a falta de interesse dos vigários em registrar com maior fidelidade a origem dos africanos "novos" que chegavam às paróquias da Ilha.

Como se não bastassem os seis óbitos, os dias quentes e úmidos daquele mês de fevereiro assistiram ainda a mais nove sepultamentos dos pretos "da Costa" de José Luís do Livramento. Em pouco menos de um mês, o proprietário viu a vida de quinze "africanos novos" serem ceifadas. Ali estava parte dos seus investimentos mais recentes, cativos que certamente haveriam de ser usados como mão de obra nas suas propriedades ou comercializados para algum outro proprietário da região. Mas isso não se resumia a um negócio malsucedido; terminava ali a vida de homens e mulheres, crianças e adultos que se viram obrigados a deixar sua terra natal para viver o sofrimento da escravidão no outro lado do Atlântico. ${ }^{1}$

Não é possível saber ao certo o porquê da morte desses escravos. Mas é provável que tenham sido vitimados por alguma das moléstias que há algum tempo assolavam os "imigrantes" negros que chegavam à Ilha de Santa Catarina. Talvez tivessem contraído "bexigas", "malina”, "sarampo", ou alguma outra dita "moléstia interior", doenças que estavam entre as principais causas de morte dos africanos recém-desembarcados na Vila do Desterro entre as décadas de 1810 e $1820 .^{2}$ Não se tratava de uma fatalidade, pois a insalubridade, os desgastes físico e emocional sofridos pelos africanos escravizados durante a viagem através do Atlântico e a realidade do cativeiro deixavam-nos em condições muito frágeis de saúde. As enfermidades que assolaram a vida dos quinze africanos "boçais"

1 Os registros de óbito mencionados nos quatro primeiros parágrafos vêm do Arquivo Histórico Eclesiástico de Santa Catarina (doravante AHESC). Livro do Registro de Óbitos de Escravos da Freguesia de Nossa Senhora do Desterro,1799-1814. Os assentos estão entre as fls. 97v-100.

2 Entre janeiro de 1810 e dezembro de 1829, as "bexigas", "malina" e o "sarampo" foram declaradas como sendo a causa mortis de 109, 43 e 10 óbitos, respectivamente. Cf. AHESC. Primeiro e Segundo Livro de Registro de Óbitos de Escravos da Freguesia de Nossa Senhora do Desterro, 1799-1814/18141834. 
do capitão Livramento se caracterizavam como uma das expressões da escravidão que se espalhava pelo litoral sul do Brasil.

Episódios de violência como esse se tornavam comuns no cotidiano da Vila do Desterro e da Ilha de Santa Catarina e se repetiriam muitas vezes nas duas décadas seguintes. O capitão José Luís do Livramento era apenas mais um dos inúmeros senhores de terras que decidiram usar o trabalho escravo como alternativa para desenvolver e acelerar o cultivo das lavouras de alimentos que se espalhavam pelos quatro principais distritos da Ilha: a Vila do Desterro e as freguesias de Nossa Senhora da Lapa do Ribeirão, Nossa Senhora da Conceição da Lagoa e Nossa Senhora das Necessidades. Já desde o fim do século XVIII, a opção pelo trabalho escravo vinha se consolidando como um fator importante da produção agrícola local. Este capítulo trata justamente da presença de africanos na Ilha de Santa Catarina e busca esboçar uma história das rotas pelas quais eles ali chegaram como também uma cronologia da escravidão e das chances de liberdade que tiveram, entre meados do século XVIII e princípios do século XIX. Esta reconstituição se baseou principalmente em registros eclesiásticos de batismos, casamentos e óbitos, assim como em documentos de ordem administrativa e fiscal, mapas censitários, portuários, passaportes e relatórios de governo.

\section{A primeira fase de ocupação do litoral}

A baía da Ilha de Santa Catarina era conhecida pelos navegantes do Atlântico Sul desde o século XVI, por oferecer um porto protegido e a possibilidade de abastecimento em madeira, água e alimentos. $\mathrm{Na}$ primeira fase da ocupação europeia do litoral catarinense, entre meados do século XVII e meados do XVIII, já havia escravos indígenas e de origem africana entre os colonizadores. Os núcleos de povoamento do litoral foram fundados por vicentistas em meados do século XVII: São Francisco do Sul (1658), Nossa Senhora do Desterro (1662) e Santo Antônio dos Anjos da Laguna (1682).

O memorialista Paulo José Miguel de Brito, que escreveu em 1816, conta que Francisco Dias Velho Monteiro, fundador de Desterro, levou para o povoado dois filhos, duas filhas, dois frades, um casal e seus três filhos e 500 índios "domesticados", para os quais foram distribuídas 
terras a cultivar. Anos depois, Dias Velho foi assassinado por corsários holandeses, e seus familiares se retiraram para Laguna, só ficando na Ilha os índios que haviam ido com ele. ${ }^{3}$ São poucas as referências aos índios carijós que já habitavam a Ilha e, no século XVI, abasteciam de farinha de mandioca os navios de passagem. Naquela época, o grande envolvimento dos paulistas era com o apresamento de índios, o que reduziu drasticamente as populações autóctones do litoral, incluindo também as da Ilha. A luta contra os "gentios" permitia a aquisição de mão de obra servil de forma barata aos senhores de terras das capitanias do Centro-Sul, num momento em que o mercado de escravos africanos ainda não estava totalmente consolidado no Brasil.

Somente depois de 1700 , os vicentistas voltaram a ocupar a Ilha, para ali transferindo famílias, escravos e agregados. Muitos desses vieram por conta das oportunidades de riqueza e poder naquela situação de fronteira aberta, abundante em recursos como terras e índios para administrar. Em 1712, quando o viajante francês Frézier esteve na Ilha de Santa Catarina, já havia ali e na "terra firme", "147 pessoas brancas, alguns índios e negros libertos estabelecidos à beira-mar." Parece claro que os primórdios da ocupação da Ilha em nada diferem dos de outras regiões fronteiriças nas quais os portugueses se instalaram, dependendo do apoio de índios aldeados e poucos escravos africanos, a sondar o potencial do território. Jacintho Mattos, pesquisador do início do século XX, apurou que, dos escravos que existiam na Ilha no início do século XVIII, "havia do gentio, de Guiné, Macau, Mina, Benguela", entre outros. A incidência de cativos africanos, e até mesmo de asiáticos, era certamente muito menor à de indígenas, naturais da região e trabalhadores predominantes do Brasil meridional recém-ocupado no século XVII e início do XVIII. Segundo Mattos, cuja pesquisa se baseou em registros eclesiásticos, "os índios eram da aldeia de $S$. Lourenço, Carijós e até da aldeia da capitania do Espírito Santo. Na documentação havia a indicação que estavam sob a 'administração' deste ou aquele proprietário e até do próprio vigário". ${ }^{5}$ Aos poucos, a força de trabalho indígena foi substituída pela dos homens livres que continuavam a migrar para essas paragens, e também por

3 BRITO, 1829, p. 14.

4 Ibidem, p. 19.

5 MATTOS, 1918, p. 72. Sobre a administração particular dos indígenas, ver MONTEIRO, 1994. 
escravos africanos, que provavelmente chegavam pelo tráfico marítimo que seguia à bacia do Rio da Prata.

\section{0 projeto da Coroa para Santa Catarina e seus desafios}

Uma nova fase da ocupação começou em meados do século XVIII, quando o litoral catarinense foi alvo do projeto estratégico de colonização e exploração implementado pela Coroa portuguesa, passando com isso a integrar o circuito do Atlântico português. A Ilha de Santa Catarina, elevada a Capitania em 1738, sob o comando do brigadeiro José da Silva Paes, recebeu fortificações para proteger sua baía e casais açorianos e madeirenses para ocupar seu território. Esses casais fundaram núcleos de povoamento em vários pontos da Ilha e do litoral adjacente. O projeto inicial da Coroa era desenvolver a região a partir do trabalho livre dos colonos, em várias unidades familiares agrícolas e manufatureiras. A produção consistiria de culturas de interesse do Reino, como trigo, algodão e linho cânhamo. Em uma das correspondências entre o rei e o governador da capitania D. José de Manuel e Melo, datada de novembro de 1754, é possível perceber as expectativas de Portugal para a nova colônia. Uma das recomendações feitas ao oficial de governo pelo conselho do rei era a de que ele deveria ter "especial cuidado na continuação da lavoura e aumento das fábricas" e também de não "permitir a pobreza destes povos entretê-los com trabalho que não lhes seja útil”. ${ }^{6}$

Mas o projeto estratégico de fortificação e ocupação da Ilha, evitando a cobiça espanhola, não se resumiu a isso (tampouco evitou a tomada da Ilha pelos espanhóis, em 1777). O litoral catarinense foi também incorporado à área de exploração da baleia, e o monopólio da caça e da produção de óleo foi arrendado por contrato a particulares, a partir de 1742. Entre 1746 e 1796, foram fundadas cinco armações baleeiras no litoral catarinense, unidades escravistas de grande porte, algumas com famílias escravas e toda a complexidade de administração cotidiana comparável à dos engenhos açucareiros ou, mais tarde, das

6 BIBLIOTECA NACIONAL. Seção de Manuscritos. Col. Carvalho, 15, 4, 17, n. 74. Consulta do Conselho Ultramarino sobre o informe do governador da Ilha de Santa Catarina referente às freguesias pertencentes à sua jurisdição, e à cultura do trigo, linho, algodão, cânhamo e mandioca da mesma Ilha. Lisboa, 22 de novembro de 1754. 
fazendas de café. Em torno das armações baleeiras, mas também em outros pontos do litoral, se desenvolveram os núcleos de povoamento de açorianos, cuja economia floresceu voltada para a produção de abastecimento. ${ }^{7}$ Administradas a partir de Lisboa pelo contratador (ou pela Companhia, a partir de 1765), recebiam do administrador no Rio de Janeiro todos os apetrechos necessários e a mão de obra indispensável para o seu funcionamento (ver Mapa 1). A Armação da Piedade, a maior e mais antiga - fundada em 1746 no continente, ao norte da Ilha de Santa Catarina -, tinha 107 escravos em 1750, todos africanos. ${ }^{8}$

Até as duas últimas décadas do século XVIII, existiam poucos escravos nos núcleos de povoamento de açorianos na Ilha de Santa Catarina e no litoral próximo. A mão de obra cativa apenas complementava o trabalho exercido pelos colonos recém-instalados. A própria Coroa portuguesa, no implemento da colonização açoriana, na década de 1750 , reprovava o uso da mão de obra escrava pelos colonos. Oficialmente, o que incomodava era a "ociosidade" dos seus súditos, já observada em outras partes do Brasil onde a escravidão predominava. Mas é provável que a Coroa também receasse a formação de uma elite proprietária com maior capacidade para contestar o seu domínio.

Nesse sentido, o pedido de José Francisco de Sousa Machado e de sua esposa Catarina Eugênia Bitancurt à Coroa é ilustrativo. O casal, natural da Ilha de São Jorge, desembarcou na Ilha de Santa Catarina nas primeiras levas de colonos açorianos, por volta do ano de 1748. Assim que se estabeleceram em suas sesmarias, fizeram um requerimento à "Vossa Majestade" para que lhes facilitasse a compra de escravos, alegando serem de "nascimento distinto e de nobreza qualificada" e que, em virtude disso, não poderiam "acudir a cultura das terras". Se por acaso o fizessem, se trabalhassem com as próprias mãos em suas lavouras, decairiam "da sua nobreza ao exercitar-se no mecanismo". Faziam menção ao "defeito mecânico", a discriminação que havia na hierarquia social portuguesa contra aqueles que exerciam trabalhos manuais. Requerimento semelhante foi encaminhado pelos colonos Antônio Francisco Muniz

\footnotetext{
Até o final do século XVIII foram estabelecidos no litoral catarinense os seguintes pontos de "pescarias do sul": a Armação da Piedade (1746), a da Lagoinha (1772), a de Itapocoróia (1778), a de Garopaba (1793-1795) e o seu suplemento de Imbituba (1796). Cf. ELLIS, 1969.

$8 \quad$ SILVA, 1992, p. 56.
} 
Barreto e sua esposa Rita Caetana da Silva. Naturais da Ilha de São Miguel, diziam-se "de nobre qualidade" e por isso solicitavam autorização para terem escravos que os servissem. A resposta do soberano aos súditos foi negativa nos dois casos, justificando que "não era justo acostumar esta Nova Colônia ao prejudicial abuso de não trabalharem os brancos, que nas outras vivem em prejudicial ociosidade, por ocasião deste mau costume". ${ }^{9}$

Ainda no século XVIII, precisamente em 14 de outubro de 1751, a Coroa portuguesa lançou um alvará que ajudou a regular o tráfico negreiro no Sul do Brasil, a fim de evitar o contrabando de escravos para os domínios espanhóis. O teor do documento apontava preocupação com o fisco e obrigava os negociantes a apresentar guias de transporte dos escravos que levavam aos oficiais da provedoria, instalados nos portos por onde passassem..$^{10}$ Sabendo que a Ilha de Santa Catarina estava na rota marítima para a bacia do Rio da Prata, e que os comerciantes do Rio de Janeiro se esforçavam para abastecer de escravos as regiões sulinas de colonização espanhola - mesmo sendo esse comércio considerado contrabando -, não é difícil imaginar a possibilidade de os ilhéus adquirirem escravos via comércio costeiro. Bastava que tivessem recursos para pagar seus custos. Residentes da freguesia Nossa Senhora da Conceição da Lagoa, o casal João de Andrade e Josefa Ignácia Caetana, ambos açorianos (ele, natural da Ilha de São Miguel, ela, da Ilha Terceira) adquiriu, na década de 1760, uma africana de nome Isabel, registrada como de nação "benguela". Sabemos disso porque Isabel deu à luz o pequeno Antônio, levado à pia batismal em 17 de janeiro de 1767, batizado como escravo dos senhores de sua mãe. Teve como padrinho Matheus Vaz, homem livre e possivelmente vizinho do casal de açorianos. ${ }^{11}$ A Freguesia da Lagoa estava situada na costa da grande lagoa de água salgada no interior da Ilha

9 ARQUIVO HISTÓRICO ULTRAMARINO. Projeto Resgate Barão do Rio Branco. Documentos Avulsos, Santa Catarina (doravante AHU-SC). Requerimento de José Francisco de Sousa ao rei [D. João V], solicitando escravos para poderem trabalhar na lavoura de suas terras, e ficar como obrigação do pagamento deste empréstimo os frutos da terra em farinha para tropas. Caixa 1, doc. 60; Carta do sargento-mor de Batalha, José da Silva Pais, ao rei [D. José], sobre a carta que fez o governador da Ilha de Santa Catarina, D. José de Melo Manuel, acerca da dúvida do local para estabelecer a capital de Santa Catarina e onde deveria residir o governo. Caixa 2, doc. 112.

10 ALVARÁ de 14 de outubro de 1751, In: SILVA, 1842, p. 111-112 apud BERUTE, 2006, p. 35-37.

11 AHESC. Primeiro Livro de Batismos da Freguesia de Nossa Senhora da Conceição da Lagoa, 1751-1769. Fl 191v. Os livros da Lagoa foram transcritos por Maria Helena Schweitzer no âmbito do projeto Africanos no Sul do Brasil, coordenado pela professora Beatriz Gallotti Mamigonian. 
de Santa Catarina; desde o início da década de 1760, vinha recebendo um número pequeno, embora regular, de africanos novos e escravos africanos ou crioulos (nascidos no Brasil). Parte desses escravos novos não era batizada na Lagoa, mas aparecia nos registros quando batizava seus filhos. Nos trinta anos decorridos entre 1758 e 1787 foram registrados na Freguesia da Lagoa 153 batismos envolvendo escravos. ${ }^{12}$ Entre esses, se contavam os batismos de africanos recém-chegados e crianças nascidas de mães cativas africanas e crioulas. Nos trinta anos seguintes, de 1788 a 1817, o número dos escravos que passaram pela pia batismal naquela freguesia foi muito maior, 478 , ou seja, três vezes mais que nas três décadas anteriores. Em 1796, a freguesia contava 329 "fogos", ou unidades familiares e produtivas, e quase dois mil habitantes, sendo $81 \%$ livres, $18 \%$ escravizados e um pequeno número de pessoas libertas. No mesmo ano, a freguesia de Desterro tinha 3747 habitantes, sendo 26\% escravos, e o distrito do Ribeirão da Ilha, um total de 1020 habitantes, sendo deles quase $30 \%$ escravos. ${ }^{13}$

\section{A economia de abastecimento e o comércio de escravos}

O período de grande afluxo de escravos para a Ilha de Santa Catarina entre as duas últimas décadas do século XVIII e as duas primeiras do XIX coincide com sua inserção no mercado colonial de alimentos, através das ligações comerciais com outros portos do Brasil. As lavouras catarinenses passaram a ofertar inúmeros produtos para ajudar a suprir as demandas das áreas do Centro-Sul e Nordeste. O principal artigo produzido e exportado pelos ilhéus era, sem dúvida, a farinha de mandioca. Sua comercialização integrava a capitania a um dos mais importantes sistemas econômicos da América portuguesa: o mercado de abastecimento de víveres centrado na praça comercial do Rio de Janeiro. A ascensão econômica dos comerciantes dessa praça articulava o tráfico de escravos

12 AHESC. Livros 1, 2 e 3 de Batismos da Freguesia de Nossa Senhora da Conceição da Lagoa (1751-1769; 1770-1780; 1781-1789).

13 AHU-SC. Rezumo Geral de Toda a População Pertencente ao Governo da Ilha de Santa Catharina, Formado pelos mappas que derão os officiaes de cada hum dos Distritos do mesmo Governo. Em $1^{\circ}$ de Janeiro de 1796. Ofício do [governador da Ilha de Santa Catarina] tenente-coronel João Alberto Miranda Ribeiro ao vice-rei do estado e mapas referentes a extensão e limites da Ilha de Santa Catarina e distritos de sua jurisdição. Caixa 6, doc. 387. 
entre Angola e o Rio de Janeiro, que abastecia as regiões do Centro-Sul; o contrabando para o Rio da Prata; e a distribuição de alimentos nas áreas de mineração e de produção de açúcar no Sudeste. ${ }^{14}$

Um mapa portuário da Ilha datado de 1803, tirado a mando das autoridades da provedoria da capitania de Santa Catarina, demonstra o intenso movimento de embarcações envolvidas nesse comércio costeiro com os portos do Sul e que aportavam em Desterro, de passagem ou como destino principal. Foram contabilizadas naquele ano 96 embarcações que subiram ou desceram pela Ilha de Santa Catarina de vários lugares da costa brasileira, sendo que quase $40 \%$ delas vinham do porto do Rio de Janeiro. Muitos desses iates, lanchas e sumacas transportavam artigos ditos "de fazenda", como vinho, sal, algodão, vinagre, azeite, mas também escravos. Naquele ano, foi notificada a passagem de 338 escravos na carga de 36 embarcações dos portos do Rio de Janeiro, Bahia e Pernambuco para as praças comerciais de Rio Grande, Desterro e Laguna. Muitos deles ficaram em Desterro. E foi no mês de dezembro do referido ano que o mestre Joaquim José Prates atracou a sumaca Brilhante em Desterro, trazendo do Rio de Janeiro uma carga de 43 escravos novos, 30 "fardos de fazendas" e 4 "pipas" de vinho. Talvez fosse essa carga a contrapartida comercial para trocar pelos produtos da terra produzidos na Ilha. ${ }^{15}$

Ao que parece, à medida que a Ilha de Santa Catarina foi se integrando a esse circuito comercial de gêneros de abastecimento, a população escrava foi se ampliando. Alguns traços do quadro da demografia escrava nos demonstram isso. Os mapas populacionais levantados pelas autoridades da capitania demonstram que de 1796 até 1814, o número de escravos de toda a Ilha aumentou em quase $40 \% .{ }^{16} \mathrm{O}$ uso da mão de obra escrava nas pequenas e médias propriedades agrícolas locais passou a ser

14 FRAGOSO, 1998, p. 117-151.

15 AHU-SC. Embarcações que entrarão no Porto desta Ilha no ano de 1803, com as necessárias declarações de seu destino e carga. Caixa 8, doc. 462.

16 Este dado foi obtido a partir da consulta dos censos populacionais de 1796 e 1814, respectivamente; ver: AHU-SC. Rezumo Geral de Toda a População Pertencente ao Governo da Ilha de Santa Catharina, Formado pelos mappas que derão os officiaes de cada hum dos Distritos do mesmo Governo. Em $1^{\circ}$ de Janeiro de 1796. Ofício do [governador da Ilha de Santa Catarina] tenente-coronel João Alberto Miranda Ribeiro ao vice-rei do estado e mapas referentes a extensão e limites da Ilha de Santa Catarina e distritos de sua jurisdição, cx. 6, doc. 387; BIBLIOTECA NACIONAL. Seção de Manuscritos. Resumo geral de toda a população pertencente ao Governo da Capitania da Ilha de Santa Catarina, extrahido dos Mapas que derão os Comandantes dos Destritos do ano de 1814. I-31, 29, 18, n. 6. 
cada vez mais corrente. A essa altura, os planos da Coroa portuguesa para a colonização da Ilha de Santa Catarina e do litoral próximo, através do trabalho livre de colonos e feitorias coloniais, já haviam sido frustrados.

\section{As rotas, o volume e os envolvidos no tráfico de escravos para Santa Catarina}

Em 1808, a transferência da Corte Imperial para o Rio de Janeiro e a nova conjuntura da economia colonial trouxeram dinamismo econômico para as áreas de produção de alimentos do litoral catarinense, como fizeram também com outras regiões do Sul e Sudeste. Essa fase de distinta prosperidade vivida no litoral catarinense, graças às exportações de alimentos, era em grande parte sustentada pela compra de africanos novos para as pequenas e médias propriedades agrícolas. Se antes os registros de batismo de africanos novos eram pouco numerosos, a partir de 1810, a importação de africanos novos se tornou mais volumosa. Um levantamento dos registros de batismo de escravos em Desterro, na Lagoa e no Ribeirão da Ilha na primeira metade do século XIX aponta uma importação de africanos bastante regular entre 1810 e 1829, com picos em alguns anos. ${ }^{17}$ Nas três freguesias, o registro de africanos novos diminuiu drasticamente após a lei de proibição do tráfico de escravos, promulgada no ano de 1831, mesmo que tenha havido alguns africanos batizados até a década de $1840 .^{18}$

Não encontramos evidências de tráfico atlântico tendo como principal destino a Ilha de Santa Catarina nesse período, o que significa dizer que os africanos que aqui aportaram não vieram diretamente da África. Mas o porto de Desterro e suas imediações serviram de parada e de abastecimento para alguns navios de partida para a costa africana, como no caso do bergantim Providente, cujo mestre era Jerônimo Domingues. Provavelmente vindo do Rio de Janeiro, em maio de 1812,

17 Os dados sobre o Ribeirão da Ilha provêm das transcrições feitas por Fernanda Zimmermann, no âmbito do projeto Africanos no Sul do Brasil. Os dados sobre Desterro provêm de MALAVOTA, 2007, p. 91. A autora gentilmente nos cedeu as transcrições de batismos de Desterro.

18 AHESC. Livro 1 de Batismos de Escravos da Freguesia de Nossa Senhora da Conceição da Lagoa (18011864) e Livros 1, 2 e 3 de Batizados da Freguesia de Nossa Senhora da Lapa do Ribeirão da Ilha (18071825; 1825-1841; 1846-1854). 
o Providente partiu do porto do Desterro em direção à costa oriental africana, saída que foi registrada pelas autoridades alfandegárias da Ilha. As correntes marítimas favoreciam a escolha dessa rota para embarcações que buscavam o Índico. Tendo adquirido escravos nas proximidades de Quelimane (Moçambique), depois de 65 dias em alto mar, em fevereiro de 1813, o bergantim do capitão Jerônimo Domingues retornou à costa brasileira. Chegando ao porto do Rio de Janeiro, com cerca de 260 escravos (dos 277 que embarcara originalmente). Esta não fora a primeira viagem de Jerônimo à África a bordo do Providente. Sabemos que dois anos antes, ele já tinha feito duas viagens a Moçambique, onde adquirira mais de 450 escravos africanos..$^{19}$ É bem provável que o litoral de Santa Catarina integrasse a rota do tráfico de escravos que ligava as praças comerciais do Rio de Janeiro às da África Oriental, nas décadas de 1810 e 1820, momento em que aquela rota comercial ganhava impulso. A ligação de comerciantes especializados no tráfico de escravos de tal região africana com o litoral catarinense também nos sugere isso. Entre 1822 e 1826, um dos mais importantes traficantes da rota Rio de Janeiro-Moçambique, Zeferino José Pinto de Magalhães, despachou em várias viagens mais de 40 escravos do porto do Rio de Janeiro para Laguna. ${ }^{20}$

Da mesma forma, boa parte dos africanos residentes na Ilha de Santa Catarina e no litoral adjacente fez a travessia atlântica em barcos de negociantes da praça do Rio de Janeiro e foi reembarcada para Santa Catarina com outras mercadorias, para ali levadas a fim de serem trocadas por gêneros de abastecimento, principalmente a farinha de mandioca. Um levantamento dos registros de despachos de mercadorias e passaportes de pessoas viajantes emitidos no Rio de Janeiro aponta

19 Relação dos passaportes reais que se expedirão pela Secretaria do Governo da Ilha de Santa Catharina, e dos papeis com que sahirão as Embarcações etc. (1812). In: REVISTA DO IHGSC, 1914, p. 95-101; ELTIS et alii, disponível em www.slavevoyages.org

20 ARQUIVO NACIONAL DO RIO DE JANEIRO (doravante ANRJ). Coleção da Intendência de Polícia da Corte. Códice 390: Receita dos direitos de despacho de escravos para os portos do Sul, 18151826. Data dos despachos: 22/03/1822; 25/05/1823; 26/05/1823; 11/05/1824; 12/05/1824; 16/02/1824; 12/04/1826 e 16/08/1826; Coleção da Intendência de Polícia da Corte. Códice 421. Passaportes (registros de pessoas que partem ou despacham escravos, 1809-1831). Data dos registros: 11/03/1823 e 12/05/1824; . Coleção da Intendência de Polícia da Corte. Códice 424: Lançamento de atestados e remessa de escravos para várias localidades, 1826-1833. Data dos registros: 17/08/1826. Material transcrito por equipe coordenada por João Fragoso e Roberto Guedes Ferreira e que nos foi gentilmente cedido. 
os nomes daqueles envolvidos, o volume e a cronologia do transporte de escravos saindo daquele porto para Santa Catarina. Foi esse o caso de Joaquim Dias Moreira, um dos principais negociantes de escravos da praça carioca identificados na pesquisa do historiador Manolo Florentino, que despachou 30 escravos novos em duas viagens para a Ilha de Santa Catarina em junho de $1811 .{ }^{21}$ Outros documentos confirmam as conexões de comerciantes de Desterro com traficantes da praça do Rio de Janeiro, nas primeiras décadas do XIX, para o abastecimento de escravos novos. Dos registros de óbito de escravos em Desterro constam onze escravos africanos pertencentes a Manoel José das Neves, que faleceram entre 1808 e 1811, em depósito na casa do comerciante Francisco de Paula Tavares, comerciante de Desterro. Neves era traficante da praça do Rio de Janeiro, também identificado por Florentino. Tavares aparece como comerciante na lista de José Luís do Livramento e Antônio José da Costa. Entre os óbitos constam ainda três africanos boçais falecidos entre agosto e setembro de 1811 e que pertenciam a "José de Carvalho Ribeiro e Companhia". Ribeiro está igualmente na lista daqueles identificados como comerciantes da rota Rio de Janeiro - Costa da África por Florentino. ${ }^{22}$ $\mathrm{O}$ fato de africanos terem falecido antes mesmo de serem vendidos para proprietários locais expõe os mecanismos do comércio de escravos na fase de distribuição pelo interior, a partir da praça comercial do Rio.

O senhor de escravos apresentado no início do capítulo, o capitão José Luís do Livramento, era outro desses homens de negócio do Desterro que mantinha contatos mercantis com os traficantes do Rio de Janeiro. Alguns indícios apontam que ele e outros membros de sua família foram os maiores importadores de escravos africanos da capitania, depois província de Santa Catarina, entre as décadas de 1810 e 1820 . Um sinal indireto disso pode estar ligado ao fato de ele ter enterrado 33 escravos africanos registrados como de sua propriedade entre 1803 e 1824, sendo

21 ANRJ. Coleção da Intendência de Polícia da Corte. Códice 421: Data dos registros: 01/06/1811 e 06/06/1811.

22 AHESC. Livros de Registro de Óbitos de Escravos da Freguesia de Nossa Senhora do Desterro (1799-1814); AHU-SC. Relação das Loges de Fazenda de Varejo, que á prezentemente na Vila Capital de Nossa Senhora do Desterro da Ilha de Santa Catharina: E do quanto importarão as [Carregações] de Fazendas que entrarão para ellas nos 3 anos seguintes. Ofício do [governador da Ilha de Santa Catarina] tenente-coronel João Alberto Miranda Ribeiro ao vice-rei do estado e mapas referentes a extensão e limites da Ilha de Santa Catarina e distritos de sua jurisdição. Caixa 6, doc. 387; FLORENTINO, 1997, p. 254-56. 
que a maioria era de escravos novos, isto é, recém-desembarcados. ${ }^{23}$ Também reforçam a ideia os 12 africanos que ele batizou num período de cinco anos, escravos com idade entre 10 e 30 anos, ou seja, em pleno vigor físico, para serem aproveitados como força de trabalho. ${ }^{24}$ José Luís do Livramento já era, em finais do século XVIII, um comerciante importante da praça desterrense. Sabemos que ele e seu cunhado Antônio José da Costa foram os donos das "lojas de fazenda" (casa comerciais) que mais importaram mercadorias no triênio de 1794-1796, totalizando algo em torno de 26:000\$000 (26 contos) de réis, quantia bastante considerável para o período. ${ }^{25}$ Além disso, ambos aparecem entre os mais importantes comerciantes e exportadores de farinha de mandioca da Ilha de Santa Catarina. Os seus armazéns de atacado escoavam grande parte da produção agrícola das freguesias da Ilha e litoral próximo, e eles também concentravam boa parte da frota marítima da região com capacidade para comerciar mar afora nos portos da costa brasileira. Das sete embarcações que havia na Ilha, três estavam em nome de Antônio José da Costa, dois bergantins e uma "lanxa de coberta". Sabemos que em 1783, José Luís do Livramento foi sócio da corveta Bom Piloto, juntamente com seu sogro Tomás Francisco da Costa, seu cunhado Antônio José da Costa e João Marcos Vieira. ${ }^{26}$ Com o passar do tempo, José Luís do Livramento e Antônio José da Costa habilitaram seus filhos na arte da mercancia. Não foi à toa que encontramos João Luís do Livramento, em 1823, despachando seis escravos novos do Rio de Janeiro para a Ilha. Um ano depois, Miguel Joaquim do Livramento, outro filho de José, aportou em

23 AHESC. Livros 1 e 2 de Óbitos de Escravos da Freguesia de Nossa Senhora do Desterro (1799-1814 e 1814-1834).

24 AHESC. Livros 2 e 3 de Batismo de Escravos da Freguesia Nossa Senhora do Desterro (1798-1818 e 1818-1840); Os registros dos africanos em nome de José Luís do Livramento se encontram entre 27/12/1813 e 01/06/1819.

25 AHU-SC. Relação das Loges de Fazenda de Varejo, que á prezentemente na Vila Capital de Nossa Senhora do Desterro da Ilha de Santa Catharina: E do quanto importarão as [Carregações] de Fazendas que entrarão para ellas nos 3 anos seguintes. Ofício do [governador da Ilha de Santa Catarina] tenente-coronel João Alberto Miranda Ribeiro ao vice-rei do estado e mapas referentes a extensão e limites da Ilha de Santa Catarina e distritos de sua jurisdição. Caixa 6, doc. 387.

26 AHU-SC. Relação do número e qualidade das Embarcações que ha na Ilha de Santa Catarina, e nas Vilas do Rio de São Francisco, e da Laguna. Em 17 de Novembro de 1797. Ofício do [governador da Ilha de Santa Catarina] tenente-coronel João Alberto Miranda Ribeiro ao vice-rei do estado e mapas referentes a extensão e limites da Ilha de Santa Catarina e distritos de sua jurisdição. Caixa 6, doc. 387. Sobre a lancha Bom Piloto, ver PEREIRA, 1997, p. 222-223. 
Desterro com mais 52 escravos novos, o maior desembarque de africanos feito por um comerciante desterrense de que se tem notícia. Três anos depois, foi a vez do outro filho, Francisco Luís do Livramento, atracar com mais 32 africanos. Pelo lado da família Costa, os despachos de escravos também eram constantes. ${ }^{27}$

Os negociantes de escravos de "grosso trato" do Rio de Janeiro, que traziam escravos diretamente da costa da África, e os negociantes das principais praças comerciais do litoral catarinense (Desterro, Laguna e Rio de São Francisco) foram os principais responsáveis pelo desembarque de milhares de africanos no litoral de Santa Catarina. A partir dos despachos oficiais emitidos pela Intendência de Polícia do Corte do Rio de Janeiro, sabemos que entre 1811-1830 foram remetidos para Santa Catarina e efetivamente registrados cerca de 1700 escravos. ${ }^{28}$ É possível que o volume tenha sido bem maior, visto que o comércio clandestino era habitual e que esse registro exclui o possível comércio de escravos através de rotas terrestres, pelos diversos caminhos que interligavam as capitanias/províncias do Rio de Janeiro e São Paulo à de Santa Catarina.

Tomando como base o batismo dos africanos novos que passaram pelas paróquias do Desterro, Lagoa e Ribeirão nas décadas de 1810 e 1820, período em que se registrou o maior fluxo de entrada de africanos na Ilha, é possível saber de que áreas do continente africano eles provinham. Aproximadamente 69,4\% eram da África Centro-Ocidental (Congo, Angola, Benguela); 21,7\% eram da África Oriental (Moçambique); e 8,9\% da África Ocidental (Costa da Mina). Esse perfil de africanos que passaram a integrar a população escrava da Ilha é muito semelhante ao da cidade do Rio de Janeiro, conforme pesquisa de Mary Karasch. ${ }^{29}$ As "nações" africanas com as quais eram identificados os escravos - fosse por traficantes, na ocasião das transações comerciais, fosse por autoridades, no momento da emissão de passaportes, ou ainda, como no nosso caso, pelos padres, na ocasião dos batismos -, apresentam termos imprecisos, que, na maioria das vezes, fazem referência aos portos africanos de onde saíram

ANRJ. Códice 390. Despacho de Miguel Livramento: 11/12/1824; ANRJ. Códice 421. Despacho de João Livramento: 21/04/1823; ANRJ. Códice 424. Despacho de Francisco Livramento: 22/10/1827.

28 ANRJ. Coleção da Intendência de Polícia da Corte. Códices 390, 411, 421, 424 e 425.

29 KARASCH, 2000, p. 35-66. 
as embarcações para o Brasil. "Cabinda", "Congo", "Mina", entre tantos outros nomes de nação pouco dizem sobre a real procedência ou etnia dos africanos traficados de seu continente de origem. Entretanto, esses grupos gerais de identificação poderiam adquirir um significado especial frente novas possibilidades identitárias e organizacionais adotadas pelos africanos na condição de escravos no outro lado do Atlântico. Outro agravante para uma identificação mais precisa dos africanos traficados para a Ilha tem a ver com a falta de informação e confusão feita pelos padres quando dos registros nos ritos católicos. O caso citado no começo do texto - no qual o padre Joaquim Santana Campos registra, sem saber ou por pura comodidade, os africanos do capitão José Luís do Livramento como apenas "pretos da Costa" - é exemplar. Mas não foi apenas isso. O padre Joaquim fazia muita confusão quando notificava os africanos nos livros da igreja. Foi o que aconteceu quando registrou a origem de um casal de escravos africanos de duas maneiras diferentes: Rosa e Manuel, escravos de Anastácio Silveira de Sousa, estiveram frente à pia batismal para batizar a pequena Josefa em 1795. O padre Joaquim registrou-a como "Camundá", e ele, como "Rebolo". Quatro anos mais tarde, quando o casal batizou outra filha, Jacintha, foram ambos identificados pelo padre como "Angola". ${ }^{30}$

\section{Escravidão e liberdade de africanos na Ilha de Santa Catarina}

Podemos imaginar que nesse alvorecer do Oitocentos, no momento em que os bons ventos da economia sopravam a favor da agricultura catarinense, novas lavouras e engenhos de produtos da terra como farinha, cachaça e açúcar iam aos poucos se espalhando pelo território da Ilha. Às famílias dos açórico-brasileiros transmigrados (pais, filhos e agregados) caberiam as iniciativas de organizar suas porções de terras e sítios, ano após ano, para as colheitas intercaladas de milho, feijão, café, amendoim, cana de açúcar e, principalmente, mandioca. Parte do que se colhia certamente era destinado ao consumo da casa, e o excedente poderia facilmente ser trocado nos espaços de comércio ambulante ou nas vendas fixas do Desterro, como as "tavernas de molhados" que seguiam da Rua do

\footnotetext{
30 AHESC. Livros 1 e 2 de Batismo de Escravos da Freguesia Nossa Senhora do Desterro (1771-1798 e 1798-1818). Data dos assentos: 23/03/1795 e 03/02/1799.
} 
Menino Deus para a da Cadeia. Uma quantidade maior desses produtos poderia ser direcionada ainda para o mercado vicinal de alimentos, que era estruturado pelos negociantes mais importantes daquela Praça, como os já referidos José Luís do Livramento e Antônio José da Costa, a fim de completar as remessas de víveres que subiam para os portos do Rio de Janeiro ou as que desciam para o do Rio Grande. Nessa situação, algumas famílias de lavradores livres podiam - na medida em que suas necessidades se ampliavam - recorrer à compra de alguns escravos africanos ou crioulos para ajudar na lida diária das suas roças. Tinham, em geral, um ou dois cativos. Sua aquisição se dava, provavelmente, por intermédio dos mesmos comerciantes locais para quem vendiam seus excedentes, visto que estes tinham amplo acesso ao tráfico negreiro do Rio de Janeiro. Nessas propriedades, a escravidão adotava as formas domésticas, nas quais as relações sociais e culturais entre senhor e escravo se davam nos diversos espaços de sociabilidade da casa, do trabalho e da rua, mas nem por isso eram menos violentas.

Havia também famílias que, dispondo de mais recursos (sociais, políticos e econômicos), poderiam facilmente estruturar as suas roças de alimentos em propriedades de extensão territorial mais considerável. Talvez organizassem a produção e o trabalho de forma contínua dentro da propriedade, para acelerar o plantio e a colheita. Provavelmente dispusessem de algum maquinário para o beneficiamento das culturas ali produzidas, como bolandeiras, prensas, fornos e alambiques. A escravidão que predominava num universo agrário como esse apresentava uma feição muito diferente daquela tida como estritamente "doméstica" e "minifundiária" - ou "sem importância", como definiram os historiadores catarinenses Walter Piazza e Oswaldo Cabral. ${ }^{31} \mathrm{O}$ número de escravos dessas propriedades certamente chegava a quinze ou vinte. $O$ trabalho poderia ser dividido em funções especializadas, acrescentando novas categorias socioprofissionais como escravo da roça, da casa, feitor, mestre de forno, do engenho etc. Assim, o conjunto de escravos de cada proprietário ia apresentando um quadro social muito mais dinâmico.

As senzalas deveriam ser coabitadas por indivíduos solteiros e sozinhos, mas também por famílias escravas que aos poucos se formavam,

31 PIAZZA, 1999, 1975; CABRAL, 1939, p. 163-183. 
levando em consideração suas aproximações étnicas, sociais ou culturais. Ao mesmo tempo, haveria igualmente maior cuidado e controle por parte dos senhores sobre os seus cativos, possivelmente destinando alguém para fazer tal vigilância, um homem livre ou mesmo um escravo. Em alguns casos, dependendo da habilidade do senhor, é possível que ele próprio soubesse conduzir uma política segura de controle e domínio, alternando as estratégias de reconhecimento de sua autoridade pela pedagogia da força ou pela distribuição de concessões paternais. Os escravos continuariam tentando superar as dificuldades que lhes eram impostas, vivendo, cada um ao seu modo, a vida possível do cativeiro e engendrando a cada dia os seus esquemas de resistência e luta, fosse pela liberdade ou por melhores condições de trabalho, moradia, alimentação e saúde.

Manuel Fernandes de Lessa e Maria Madalena da Silva foram desses proprietários que investiram em escravos e terras nessa fase de expansão econômica da Ilha de Santa Catarina. Eles pertenciam a um grupo que dispunha de mais recursos para financiar seus projetos agrícolas e senhoriais. Ambos eram membros da irmandade do Senhor dos Passos, um dos principais espaços de distinção social que havia na Ilha e que reunia boa parte da elite local. ${ }^{32}$ Manuel Fernandes Lessa era figura respeitada na confraria, integrando várias vezes a mesa diretora, assumindo cargos importantes como o de secretário. Detinha também uma patente militar, a de capitão das Tropas de Ordenanças. As suas credenciais deixam claro que não se tratava de um simples lavrador que tentava melhorar sua modesta roça de alimentos. As primeiras evidências de que Manuel Fernandes e Maria Madalena eram também senhores de escravos datam do início da década de 1790. Foi com base nos registros de batismo de escravos da freguesia do Desterro, lugar onde provavelmente moravam, que reconstruímos a escravaria do casal ao longo das duas décadas seguintes. ${ }^{33}$ Até 1799 , encontramos cinco escravos como de propriedade de Manuel Fernandes - grupo de escravos de tamanho razoável para a região. Na verdade, sua escravaria era uma família de cativos, um casal

32 PEREIRA, 1997, p. 184-185.

33 Reconstruímos os casos aqui analisados usando como referência os escravos que apareciam no ato do batismo de crianças escravas como de propriedade de Manuel Fernandes Lessa e Maria Madalena da Silva, fossem eles filhos, mães ou pais e padrinhos. AHESC. Livros 1 e 2 de Batismo de Escravos da Freguesia Nossa Senhora do Desterro (1771-1798 e 1798-1818). 
e três filhos, que aparentemente foram os seus primeiros escravos. As coisas pareciam ir bem com as lavouras, e não demorou muito para que Manuel assumisse o posto de um dos maiores donos de escravos da Ilha, em princípios do século XIX. Seus investimentos já não se restringiam a Desterro, pois nesse período, solicitou ao governador D. Luís Maurício da Silveira uma concessão de sesmarias na freguesia de São Miguel, no continente, próximas às margens do rio Biguaçu, para seu "melhor estabelecimento e poder empregar escravos". Em 1807, o governador fez "por bem de conceder por Sesmaria em nome de Sua Alteza Real [...] ao mencionado Capitão das Ordenanças Manuel Fernandes Lessa as contempladas cem braças de terras de frente com noventa e sete de fundo por um travessão, e quarenta e seis pelo outro na forma acima expedida". ${ }^{34}$ No período, Manuel já tinha registrado em seu nome mais de 30 escravos, a maior escravaria do Desterro.

Entre as décadas de 1790 e 1800, metade das propriedades dos senhores de escravos tinha entre um e dois escravos, eram grupos pequenos. As propriedades de porte médio, com três a dez escravos, perfaziam quase $46 \%$ das escravarias, e as que tinham acima de dez escravos - o que, na Ilha, podemos considerar como uma grande propriedade escravista - eram apenas $4 \% .{ }^{35}$ Sendo assim, Manuel Fernandes e sua esposa Maria Madalena faziam parte de um seleto grupo de senhores de escravos que compunham a pequena elite agrária local. A opção pela mão de obra escrava naquele momento de dinamismo econômico certamente ia aos pouco redefinindo a estrutura social da Ilha de Santa Catarina, organizando a sociedade entre quem tinha mais ou menos escravos. Além do enriquecimento material adquirido pela produção dos seus escravos, Manuel Fernandes adquiriu também status como grande senhor.

34 ARQUIVO PÚBLICO DO ESTADO DE SANTA CATARINA. Livro 2 de Sesmarias, 1809-1814, p. 70-72.

35 A estrutura de posse escrava foi feita com base nos assentos de batismo. Foram computados 1729 escravos, divididos entre 474 proprietários. AHESC. Livros 1 e 2 de Batismo de Escravos da Freguesia Nossa Senhora do Desterro (1771-1798 e 1798-1818). 
Mas não eram apenas Manuel e Maria Madalena que buscavam uma vida melhor; seus escravos também tinham projetos e se esforçavam para realizá-los. Para entender a dinâmica das relações sociais entre escravos e senhores e as possibilidades de mobilidade social e liberdade que estavam abertas aos africanos que chegavam nesse período à Ilha, decidimos aqui contar o caso de Antonio e Joaquina, casal de africanos identificados como da "Guiné", que foram os primeiros escravos de Manuel Fernandes Lessa e Maria Madalena da Silva. ${ }^{36}$

Antonio e Joaquina foram adquiridos por seus senhores no início da década de 1790, quando o mercado de escravos do Desterro se estruturava, e é bem provável que ainda não fossem casados. A união de Antônio e Joaquina se confirmou em 1794, quando do nascimento da pequena Benedita. Para batizar a menina, escolheram como padrinho o preto liberto Francisco Chagas. Três anos depois, nascia Genoveva, e dessa vez, o padrinho escolhido para a menina foi um homem livre, Antônio Joaquim Cidade. Passaram-se dois anos, e nasceu Maria, que foi afilhada de outro homem livre, Antônio José da Silveira. Em 1803 e 1805, o mesmo Antônio José da Silveira batizaria mais dois filhos do casal, os dois com o mesmo prenome, Francisco - a escolha do mesmo nome para duas crianças talvez esteja relacionada à morte da primeira, visto que na época, os índices da mortalidade escrava infantil eram muito altos. À medida que a família de Antonio e Joaquina crescia, Manuel Fernandes Lessa incorporava novos escravos à sua propriedade. Assim, em 1810, o casal já vivia com 10 escravos adultos, a maioria africana, e as várias crianças que nasciam ano a ano das novas famílias escravas que se formavam. ${ }^{37}$

36 Este caso foi reconstituído com base nos registros de batismo das crianças escravas declaradas como filhas do casal Antonio e Joaquina e que apareciam também como propriedade de Manuel Fernandes Lessa e/ou Maria Madalena da Silva. AHESC. Livros 1 e 2 de Batismo de Escravos da Freguesia Nossa Senhora do Desterro (1771-1798 e 1798-1818). Para esses dois livros, consideramos os assentos de batismo das seguintes crianças: Benedita (14/05/1794); Genoveva (10/01/1797); Maria (21/02/1799); Francisco (16/09/1803) e Francisco (09/03/1805). Foram acrescentados também os batismos de duas filhas do casal de mesmo nome, Francisca. Esses assentos se encontram em AHESC. Livro 8 de Batismo de Livres da Freguesia Nossa Senhora do Desterro (1802-1820). As datas do batismo das duas Franciscas são 08/03/1807 e uma data não identificada de 1811.

37 Os escravos que aparentemente compunham o plantel naquele momento eram: Rita, africana de nação "Angola"; Joaquina, "crioula"; Alexandrina, "parda" e "crioula"; Lucrécia e José, casal de africanos "pretos da Costa"; Rita e João, casal de africanos "pretos da Costa"; Catharina, africana "preta da Costa"; e Marina e Faustino, casal de africanos "pretos da Costa". 
Essa nova situação redefinia aos poucos o quadro social e hierárquico do grupo de escravos de Lessa. É provável que os escravos que chegaram depois estivessem subordinados a Antonio e Joaquina, os escravos mais antigos. Ao casal talvez coubessem as orientações acerca do funcionamento da propriedade, das regras da casa e da organização do trabalho na lavoura. Ao que parece, a nova situação projetava os dois africanos guinés a um lugar privilegiado na hierarquia da senzala, e que poderia facilmente ser legitimado e valorizado por seus senhores. ${ }^{38}$

Uma análise dos batismos dos filhos dos cativos posteriormente trazidos àquela propriedade confirma a situação de prestígio do casal no seio da escravaria. Antonio e Joaquina foram convidados para apadrinhar ali sete crianças, o que demonstra o grau de importância que tinham sobre seus companheiros de cativeiro. Interessante foi notar que o casal de africanos não retribuiu nenhum desses convites de apadrinhamento, não cedendo seus filhos para que os seus compadres escravos também os batizassem. Pelo contrário, continuaram a convidar pessoas livres e libertas, de fora da senzala, formando um parentesco ritual com homens e mulheres de status social superior. Acreditamos que essa estratégia social de compadrio lhes tenha rendido certas vantagens ao longo do tempo.

Em 28 de agosto de 1805, Manuel Fernandes Lessa decidiu conceder a liberdade a Benedita, Genoveva e Maria, as três filhas de Antonio e Joaquina. Não nos foi possível conhecer os termos dessas alforrias, se foram pagas ou doadas pelo senhor, tampouco se mais pessoas, como os padrinhos das crianças, participaram da negociação da liberdade de suas afilhadas. Não seria estranho supor que os compadres livres ajudassem o casal a libertar as filhas do cativeiro. Talvez tenha sido por gratidão que a jovem Benedita acrescentou ao seu nome o sobrenome Chagas, o mesmo do seu padrinho, o liberto Francisco Chagas. Também a pequena Maria acrescentou o sobrenome Cidade, de Antônio Joaquim Cidade. ${ }^{39}$ Após o nascimento dos dois Franciscos, os próximos filhos de Antônio e Joaquina não seriam mais escravos. Dois anos mais tarde, outra filha do casal de africanos ganharia a liberdade, na pia batismal. Em 1807, quando do batismo de Francisca, a quinta filha de Antonio e Joaquina, o padre Joaquim Santana dos Campos

38 Essa análise é inspirada em FRAGOSO, 2009.

39 As três alforrias constam no Livro de Inventário de Notas do 2o Ofício do Desterro, 1805-1842, p. 98v-99v. 
atestou a liberdade da criança, afirmando que era forra por "consentimento dos senhores, segundo me disse o padrinho", Antônio José da Silveira. A mesma cena se repetiu quatro anos depois: em 1811, outra filha do casal de guinés, também chamada Francisca, recebeu a alforria frente ao padre na pia batismal. Mais uma vez, o padrinho foi Antônio José da Silveira, e a madrinha, dona Maria Bernarda da Silva. ${ }^{40}$

Podemos imaginar que a situação de destaque dos africanos Antonio e Joaquina, comparada à dos outros escravos possivelmente com menos recursos que os seus, ajudou no processo de barganha pela liberdade de seus filhos. O fato de o casal manter uma relação mais duradoura e estável com seus senhores - e quem sabe, de maior reciprocidade -, aliado ao respeito que adquiriram dos companheiros de cativeiro e ao capital social dos parentescos rituais que firmaram com pessoas livres e libertas, os colocavam em vantagem na negociação das alforrias. Talvez tenha sido por essa razão que o casal insistiu tanto em estratégias sociais através do compadrio com "gente de melhor qualidade" que a sua. Antônio José da Silveira, que compareceu cinco vezes à pia batismal para confirmar o compromisso espiritual de padrinho dos filhos de Antonio e Joaquina, era senhor de escravos e muito próximo de Manuel Fernandes; membro da Irmandade dos Passos, chegou a presidir várias mesas da diretoria ao lado do senhor do casal de africanos..$^{41} \mathrm{~A}$ proximidade dele com Manuel poderia dar margem para virtuais interferências a favor dos seus compadres guinés. O próprio liberto africano Francisco da Chagas também era alguém que detinha status na comunidade desterrense, sobretudo no meio dos escravos. Por volta desse período, ele apadrinhou 23 filhos de escravos na freguesia. ${ }^{42}$ Somente depois de conseguir libertar seus filhos, e depois da morte de Manuel Fernandes Lessa, Antonio e Joaquina se tornaram livres. Em 20 de setembro de 1811, a viúva dona Maria Madalena da Silva entregou a alforria do casal, juntamente com a da parda Alexandrina. ${ }^{43}$

40 Os assentos de batismo das duas Franciscas encontram-se registrados em AHESC. Livro 8 de Batismo de Livres da Freguesia Nossa Senhora do Desterro (1802-1820). Ver também a nota 35.

41 PEREIRA, 1997, p. 327, 329, 338 e 349-350.

42 MALAVOTA, 2007, p. 164. A autora encontrou um tal Francisco das Chagas batizando filhos de escravos na freguesia do Desterro em fins do século XVIII e início do XIX. Ver também o capítulo 4 dessa coletânea.

43 Essas alforrias encontram-se num único registro do Livro de Inventário de Notas do $2^{\circ}$ Ofício de Desterro, 1805-1842, Acervo do Cartório do 1o Tabelionato de Notas de Florianópolis - Cartório Kotzias. 
Muitos dos escravos da Ilha de Santa Catarina não tiveram a mesma sorte ou as oportunidades de Antonio e Joaquina e seguiram até o fim de suas vidas como cativos. No período em que o casal de guinés conseguiu a sua liberdade e a dos seus filhos, a população forra do Desterro girava em torno de $3 \%$ da população total. Com base nas alforrias registradas nos livros de notas do cartório desta freguesia, sabemos que entre 1805 e 1813, mais de 140 escravos conquistaram a liberdade. ${ }^{44}$ Desses, certamente a maioria era de escravos nascidos no Brasil, e que por estarem aculturados, tinham maiores chances de se libertar. O mapa de população de Santa Catarina de 1796 demonstra que dos 110 libertos residentes na freguesia de Desterro, 75 foram identificados como "pardos" e 35 como "pretos". Estamos aqui considerando que, para os recenseadores, a categoria "pardo" poderia ser de crioulos, ex-escravos nascidos no Brasil. Desses, a maioria era de mulheres. Dez anos depois, em outro mapa de população, a maioria dos libertos na Freguesia também era de "pardos". ${ }^{45}$

Parece que a liberdade de africanos não era tão comum se comparada à dos escravos crioulos que viviam nas redondezas da Ilha. Sem uma estratégia bem elaborada, as chances reais de Antonio e Joaquina se libertarem juntamente com sua família eram muito pequenas. No entanto, terem sido incorporados à escravaria dos seus senhores ainda em finais do século XVIII, vivido a fase de expansão do tráfico de escravos na Ilha, se destacado entre outros africanos, assim como seguido as estratégias elaboradas a partir do compadrio fizeram a diferença neste caso. O certo é que, mesmo que alguns africanos conseguissem sua liberdade, todas as evidências apontam que naquele momento, na Ilha de Santa Catarina, a "dinâmica da escravidão" envolvia um crescimento muito maior da escravização que da concessão de alforrias para os africanos. A própria viúva Maria Madalena da Silva, depois de libertar alguns dos seus escravos, continuava a escravizar outros. No ano de 1814, por exemplo, ela adquiriu

44 CARTÓRIO DO 1 TABELIONATO DE NOTAS DE FLORIANÓPOLIS. Livro de Inventário de Notas do 2o Ofício de Desterro, 1805-1842.

45 AHU-SC. Rezumo geral de toda a população pertencente ao Governo da Ilha de Santa Catharina extrahida dos Mapas, que derão os Officiaes encarregados annualmente desta diligencia nos Distritos deste Departamento no anno de 1806. Ofício do [governador da Ilha de Santa Catarina] Luís Maurício da Silveira, ao [secretário de estado da Marinha e Ultramar] visconde de Anadia, João Rodrigues de Sá e Melo, enviando mapas dos resumos da produção de 1806, do consumo e exportação dos gêneros, relações das madeiras de construção, mapa da população da Ilha e mapas do regimento de Infantaria de Linha de Santa Catarina e do Corpo de Milícia desta Ilha. Caixa, 9, doc. 523. 
mais três africanos, Damião, Matheus e Manuel. ${ }^{46}$ Os dados até agora trabalhados não sugerem que as chances de liberdade tivessem alguma influência sobre a frequência ou as formas de resistência dos escravos. Parece claro, no entanto, que nessa região de pequenas propriedades e pequenas escravarias, alguns africanos "pioneiros" tiveram mobilidade social e chance de integração na hierarquia social ascendente. ${ }^{47}$

Caso os quinze africanos boçais de José Luís do Livramento (que abriram este capítulo) tivessem sobrevivido, é possível que tivessem sido vendidos para Manuel Fernandes, visto que os dois senhores se conheciam da Irmandade do Senhor Jesus dos Passos. Teriam vivenciado situações de trabalho, constituído famílias e laços sociais, enfrentado a exploração e a violência e, ainda, construído estratégias para obtenção da alforria, como muitos dos que acompanhamos nesse texto. Entretanto, não tiveram a mesma chance os "pretos da Costa" de Livramento.

\section{Fontes}

\section{ARQUIVO HISTÓRICO ECLESIÁSTICO DE SANTA CATARINA}

Livro 1 de Batismos de Escravos da Freguesia de Nossa Senhora da Conceição da Lagoa, 1751-1769.

Livro 2 de Batismo de Escravos da Freguesia de Nossa Senhora da Conceição da Lagoa, 1770-1780.

Livro 3 de Batismo de Escravos da Freguesia de Nossa Senhora da Conceição da Lagoa, 1781-1789.

Livro 1 de Batismo de Escravos da Freguesia de Nossa Senhora da Conceição da Lagoa, 1801-1864.

Livro 1 de Batismo de Escravos da Freguesia Nossa Senhora do Desterro, 1771-1798.

Livro 2 de Batismo de Escravos da Freguesia Nossa Senhora do Desterro, 1798-1818. Livro 8 de Batismo de Livres da Freguesia Nossa Senhora do Desterro, 1802-1820. Livro 1 de Batizados da Freguesia de Nossa Senhora da Lapa do Ribeirão da Ilha, 1807-1825.

\footnotetext{
46 AHESC. Livro 2 de Batismo de Escravos da Freguesia Nossa Senhora do Desterro (1798-1818). As datas dos assentos desses escravos são: 06/01/1814; 06/01/1814 e 13/06/1814.

47 Estes são temas de intenso debate na historiografia da escravidão brasileira. Ver MARQUESE, 2006, p. 107-123; SLENES, inédito.
} 
Livro 2 de Batizados da Freguesia de Nossa Senhora da Lapa do Ribeirão da Ilha, 1825-1841.

Livros 3 de Batizados da Freguesia de Nossa Senhora da Lapa do Ribeirão da Ilha, 1846-1854.

Primeiro Livro de Registro de Óbitos de Escravos da Freguesia de Nossa Senhora do Desterro, 1799-1814.

Segundo Livro de Registro de Óbitos de Escravos da Freguesia de Nossa Senhora do Desterro, 1814-1834.

\section{ARQUIVO HISTÓRICO ULTRAMARINO}

Projeto Resgate Barão do Rio Branco. Documentos Avulsos, Santa Catarina.

ARQUIVO NACIONAL DO RIO DE JANEIRO.

Coleção da Intendência de Polícia da Corte.

Códice 390. Receita dos direitos de despacho de escravos para os portos do Sul, 18151826.

Códice 411. Termos de fiança, ajuste, obrigação, lanço etc., 1822-1834.

Códice 421. Passaportes (registros de pessoas que partem ou despacham escravos), 1809-1818.

Códice 424. Lançamento de atestados e remessa de escravos para várias localidades, 1826-1833.

Códice 425. Passaportes (registros de pessoas que partem ou despacham escravos), 1822-1833.

ARQUIVO PÚBLICO DO ESTADO DE SANTA CATARINA.

Livro 2 de Sesmarias, 1809-1814.

BIBLIOTECA NACIONAL

Seção de Manuscritos. Coleção Carvalho e Documentos sobre Santa Catarina.

CARTÓRIO DO 1 ำTABELIONATO DE NOTAS DE FLORIANÓPOLIS (KOTZIAS)

Livro de Inventário de Notas do 2o Ofício de Desterro, 1805-1842. 
BERUTE, Gabriel Santos. Dos escravos que partem para os portos do Sul: características do tráfico negreiro do Rio Grande de São Pedro do Sul, c. 1790 - c. 1825. Dissertação (Mestrado em História) - Universidade Federal do Rio Grande do Sul, 2006.

BRITO, Paulo José Miguel de. Memória política sobre a Capitania de Santa Catarina. Lisboa: Typ. da Academia Real das Ciências, 1829.

CABRAL, Oswaldo. Os grupos negros em Santa Catarina. In: . Laguna e outros ensaios. Florianópolis: [s.n.], 1939.

ELLIS, Myriam. A baleia no Brasil colonial. São Paulo: Melhoramentos, 1969.

ELTIS, D. et al. Transatlantic Slave Trade Database. Disponível em: <www. slavevoyages.org>.

FLORENTINO, Manolo. Em Costas Negras: uma história do tráfico de escravos entre a África e o Rio de Janeiro. São Paulo: Companhia das Letras, 1997.

FRAGOSO, João. Homens de grossa aventura: acumulação e hierarquia na praça mercantil do Rio de Janeiro (1790-1830). Rio de Janeiro: Civilização Brasileira, 1998.

. O capitão João Pereira Lemos e a parda Maria Sampaio: notas sobre hierarquias rurais costumeiras no Rio de Janeiro, século XVIII. In: OLIVEIRA, Mônica R.; ALMEIDA, Carla M. (Org.). Exercícios de Micro História. Rio de Janeiro: Fundação Getúlio Vargas, 2009, p. 157-207.

KARASCH, Mary. A vida dos escravos no Rio de Janeiro (1808-1850). São Paulo: Companhia das Letras, 2000.

MALAVOTA, Cláudia Mortari. Os africanos de uma vila portuária do Sul do Brasil: criando vínculos parentais e reinventando identidades. Desterro, 1788-1850. Tese (Doutorado em História) - Pontifícia Universidade Católica do Rio Grande do Sul, 2007.

MATTOS, Jacintho. Material Histórico. Revista do IHGSC, Florianópolis: [s.n.]. v. 7 (1 trimestre), 1918.

MARQUESE, Rafael B. A dinâmica da escravidão: resistência, tráfico negreiro e alforrias, séculos XVIII e XIX. Novos Estudos CEBRAP 74 (2006).

MONTEIRO, John. Negros da Terra: índios e bandeirantes nas origens de São Paulo. São Paulo: Companhia das Letras, 1994.

PEREIRA, Nereu do Vale (Org.). Memorial da Irmandade do Senhor Jesus dos Passos. v. 1. Florianópolis: Ministério da Cultura, 1997. 
PIAZZA, Walter. O escravo numa economia minifundiária. Florianópolis/São Paulo: Editora da UDESC/Editora Resenha Universitária, 1975.

. A escravidão negra numa província periférica. Florianópolis: Garapuvu/ Unisul, 1999.

REVISTA DO IHGSC. Florianópolis: Typ. Da Escola Artifices. v. 3, 1914.

SILVA, Antônio Delgado da. Suplemento à coleção de Legislação Portuguesa do desembargador Antônio Delgado da Silva pelo mesmo (1750-1762). Lisboa: na Typ. de Luiz Correa da Cunha, 1842.

SILVA, Célia Maria e. Ganchos, SC: ascensão e decadência da pequena produção mercantil pesqueira. Florianópolis: Ed. da UFSC, 1992.

SLENES, Robert W. The Great Arch Descending: Reflections on Manumission Rates and Black Social Mobility in Southeastern Brazil, 1791-1888 (artigo inédito). 


\section{|| Capítulo 2 ||}

\section{Armação baleeira da Lagoinha: uma grande unidade escravista}

Fernanda Zimmermann

Em junho de 1816, um grupo de avaliadores chegou à Armação de Sant'Anna da Lagoinha, por ordem da Real Fazenda, com o objetivo de fazer um inventário completo dos bens de raiz, móveis, utensílios e escravos. Tinham acabado de concluir o inventário da Armação da Piedade, em São Miguel, e agora era a vez da segunda armação baleeira catarinense mais importante, situada no sul da Ilha de Santa Catarina.

Era um momento delicado para a administração das armações baleeiras no Brasil. O monopólio sobre a caça de baleias e produção do óleo havia cessado em 1801, e desde então, as unidades produtivas seus barcos, instalações, ferramentas e escravos - tinham revertido para a Coroa portuguesa. Sem uma administração eficiente, não rendiam; talvez até dessem gastos à Real Fazenda. O objetivo da Coroa portuguesa àquela altura era arrendar as armações catarinenses para algum grupo de investidores privados. Mas para isso, era necessário fazer um levantamento completo das propriedades, do seu estado e valor. Entre os bens das armações estavam homens e mulheres vindos de diferentes regiões da África e seus filhos já nascidos no Brasil, todos escravos "do contrato da pesca de baleias", cujas funções estavam ligadas à produção do óleo de baleia e outros produtos derivados, assim como à manutenção das armações e à subsistência de seus residentes.

Este capítulo se concentra no funcionamento da Armação da Lagoinha, nas experiências de trabalho e na organização de famílias entre os escravos que a ela pertenciam. A principal fonte utilizada para a 
pesquisa foi o Inventário dos bens da Armação da Lagoinha, de novembro de 1816. Além dele, foram utilizados documentos dos anos de 1816 a 1818 que comunicam todo o funcionamento da administração das armações de Santa Catarina, como pagamentos de trabalhadores livres, temporários, compras de materiais e prestação de contas ao administrador geral, que se encontrava no Rio de Janeiro. Também foram utilizados uma matrícula da população da Freguesia do Ribeirão da Ilha do ano de 1843, que fornece uma "fotografia" da freguesia naquele ano, incluindo a armação e seus arredores, e registros de batismo de escravos da Freguesia do Ribeirão da Ilha de 1807 a 1854, nos quais se encontram os batismos de escravos pertencentes ao Real Contrato, adquiridos por compra ou recém-nascidos.

\section{Histórico da caça à baleia no Brasil}

Segundo Myriam Ellis, autora do livro que se mantém a principal referência sobre o tema, a primeira armação baleeira fundada em território de ocupação portuguesa nas Américas foi instalada no Recôncavo Baiano em 1602, durante a união das Coroas ibéricas. O rei Felipe III concedeu um alvará ao capitão Pêro de Urecha e a Julião Miguel, autorizando-os a caçar baleias na costa do Brasil, dentro de um prazo de dez anos e com o direito de exercer o monopólio sobre a atividade até 1612. A caça da baleia já era praticada antes do século XVI por bascos, no mar da Biscaia, com técnicas aprendidas de noruegueses durante a Idade Média. Com a expansão da pesca durante o século XV, houve a diminuição do número de baleias no Golfo da Gasconha, e os mesmos biscainhos vieram anos depois iniciar portugueses, principalmente moradores das terras americanas, em tal tarefa. Com o término da concessão feita pelo rei Felipe III, em 1614 a Coroa espanhola decretou a baleia como um peixe real, estabelecendo que sua caça passaria ao seu monopólio. As armações já existentes ou que viessem a ser instaladas, apesar de pertencerem à Coroa seriam arrendadas para particulares, que seriam por elas responsáveis, mas não proprietários. Este modelo vigorou até o fim do século XVIII. O contrato era arrendado periodicamente a quem pagasse o valor mais alto. Os arrendatários tinham o monopólio da caça na região e da venda do óleo e de seus derivados; em contrapartida, eram responsáveis por investir na estrutura, na compra de escravos e na manutenção das armações. Com 
44 o término do arrendamento, toda a estrutura deveria ser inventariada e entregue novamente à administração real. ${ }^{1}$

As primeiras armações baleeiras no litoral Meridional foram fundadas ainda no século XVII, no litoral de São Paulo. A fundação das armações catarinenses esteve associada ao processo de ocupação do litoral no século XVIII, que envolveu a fortificação da Ilha de Santa Catarina e a vinda de casais açorianos para o povoamento do território. A Armação da Piedade foi a primeira delas no litoral catarinense. Foi instalada em 1746 no continente adjacente à Ilha, próximo à recém-construída fortaleza de Santa Cruz de Anhatomirim. O investimento veio de um comerciante sediado no Rio de Janeiro, Tomé Gomes Moreira, que viria a ser seu contratador. ${ }^{2}$ A Armação da Piedade se localizava quase a leste-oeste com a ponta setentrional da Ilha de Santa Catarina, ou seja, à entrada da baía norte, no que viria a ser o distrito da freguesia de São Miguel da Terra Firme. Esta se tornaria a maior e mais importante armação baleeira do litoral catarinense.

As outras foram instaladas décadas depois. A Armação da Lagoinha se localizava na costa leste da Ilha de Santa Catarina, na futura freguesia do Ribeirão da Ilha. Foi estabelecida em 1772, durante o contrato de Inácio Pedro Quintela, cuja administração conferiu grande impulso à caça da baleia no Brasil. Depois dessa, foram fundadas outras três armações no litoral catarinense. A primeira, Armação de Itapocorói, foi fundada em 1778, após a retirada das tropas invasoras castelhanas, e se estendia da ponta do Morro do Cambri à do Morro da Vigia, no continente, a cerca de quatorze léguas ao norte da Ilha de Santa Catarina (hoje, município de Penha). A segunda, Armação de Garopaba, foi estabelecida entre 1793 e 1795, ao sul do Rio Embaú e da Enseada de Brito, e tinha São Joaquim por titular de sua capela. A última foi a Armação de Imbituba, localizada no termo da Vila de Laguna. Criada no ano de 1796, servia como complemento da Armação de Garopaba. ${ }^{3}$

\footnotetext{
ELLIS, 1969, p. 25.

2 Ibidem, p. 57.

3 Ibidem, p. 57-59.
} 
Mapa 2: Localização das armações baleeiras no litoral catarinense

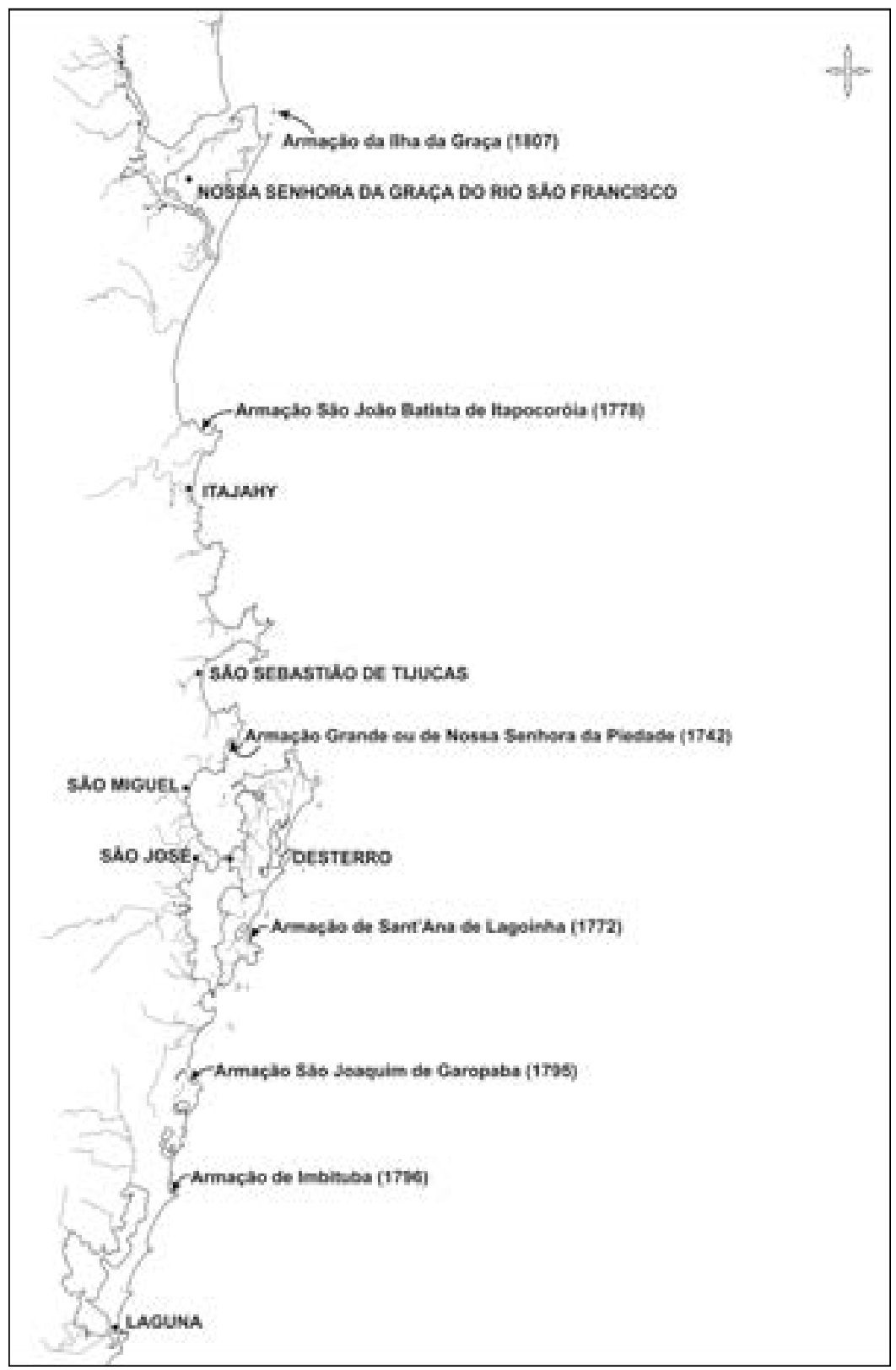


Essas armações constituíram durante muito tempo a base para uma importante atividade econômica na colônia, abastecendo o mercado interno com toicinho, espermacete e material para a produção de velas, mas principalmente o mercado externo, com óleo de baleia para iluminação. Só na segunda metade do século XIX, com a descoberta do querosene, o óleo de baleia deixou de ser indispensável. Produto de primeira necessidade, sua produção em grandes unidades produtivas, com base em trabalho escravo, era comparável à de outros produtos de exportação.

\section{O inventário da Armação da Lagoinha: o espaço, as ferramentas,} as pessoas

Até 1772, o espaço no sul da Ilha de Santa Catarina havia servido apenas como depósito de azeite de baleia produzido na Armação da Piedade. A partir de então, recebeu instalações para tornar-se também uma armação baleeira. ${ }^{4}$ Para o trabalho na Armação da Lagoinha, contavase com alguns trabalhadores livres, e a Administração da Pesca da Baleia adquiriu escravos na praça do Rio de Janeiro. ${ }^{5}$

Segundo o inventário feito em 1816, a unidade produtiva se organizava em torno de uma capela com 32 palmos de frente, 73 de fundo e 35 palmos de pé-direito, com a frente e o fundo de pedra e cal. Tinha uma imagem de Sant'Ana, sua padroeira. Ao redor da capela, e próximas ao mar para facilitar o trabalho, estavam a casa da vivenda, a casa do hospital e botica, a casa do engenho de frigir baleias e a casa dos tanques. Essa última era duplicada: havia uma localizada perto da estrutura maior e outra menor, que recebia azeite, na Ilha do Campeche. ${ }^{6}$ Para a caça da baleia, havia as "ferragens de pesca", como eram denominadas no inventário. Faziam parte do conjunto de utensílios da armação 50 facas de chacota usadas e seis facas de açúcar. Quinze facas eram usadas pelos escravos para fazer o corte transversal de cima da baleia, juntamente

Ibidem, p. 59.

5 Ibidem, p. 89.

6 Arquivo Nacional, Rio de Janeiro (ANRJ). Junta do Comércio. Real Administração da Pesca das Baleias. Caixa 360, Inventário da Armação da Lagoinha (1816). Toda descrição que segue provém desse documento, doravante referenciado como ANRJ, Inventário da Armação da Lagoinha. 
com 44 outras facas menores usadas para picar o toucinho em pequenos pedaços, antes de levá-los para derreter no engenho de azeite. Além destes materiais, havia 63 ganchos, 136 arpões e 33 lanças utilizados na captura e morte das baleias, assim como em sua condução até o trapiche. Este tinha 75 braças de comprimento e 10 palmos de largura. Quando a baleia estava próxima ao trapiche, fateixas (que eram como ganchos ou mesmo arpões) eram utilizadas para retirá-la da água. Em 1816, a Lagoinha possuía para esse serviço uma fateixa de rabo, seis fateixas pequenas e outras cinco que já estavam velhas. O engenho de azeite, ou casa do engenho de azeite, era a principal estrutura da armação. Ficava adjacente à casa do açougue, onde o toucinho era picado, e aos tanques nos quais o óleo, resultado do derretimento da gordura, era armazenado. Além dos tanques localizados na própria Armação da Lagoinha, havia, como citado, uma casa de tanques para receber azeite na Ilha do Campeche. Tinham 3,5 metros de profundidade cada um. ${ }^{7}$

O inventário também arrolava ferramentas utilizadas pelo tanoeiro, que consistiam em uma bigorna, dois martelos, talhadeiras, entre outros; havia as ferramentas do calafate, as do carpinteiro de Ribeira e de obra branca, as do pedreiro e ainda algumas que eram de diferentes usos. Entre a propriedade da armação, estavam peças de cobre, como os três fornos de fazer farinha e as medidas de vender azeite, alguns objetos de madeira e as dez grandes pipas para armazenamento, em meio uso, além de 36 pipas comuns e dezoito pequenas. ${ }^{8}$ Para o trabalho no mar, a Armação da Lagoinha tinha duas lanchas de arpoar já bastante usadas, três canoas velhas - que, no momento do inventário, serviam apenas para chegar até a baleia no momento do corte - e uma canoa pequena para rebocar toucinho. ${ }^{9}$ Havia casas onde ficavam os baleeiros e as lanchas, o cais paredão e o trapiche. Essas formavam a primeira linha das construções da armação, na qual o paredão servia ao porto e à casa do engenho, formando simultaneamente o cais em que atracavam as lanchas baleeiras.

A Armação da Lagoinha também contava com estrutura para produzir e processar os alimentos necessários à subsistência dos que ali trabalhavam. O sítio possuía uma casa de 120 palmos de frente e a mesma

7 ELLIS, 1969, p. 111-113.

8 ANRJ, Inventário da Armação da Lagoinha.

9 Ibidem. 
medida de fundo, tendo uma meia água contígua, com 40 palmos de frente e 13 de longo. A casa possuía uma sala e um quarto com paredes de pedra e cal, e frontais de tijolos com três fornalhas para fazer farinha. Também fazia parte do conjunto uma casa de 60 palmos de frente e 40 de fundo, levantada sobre esteiros, onde estava o engenho de ralar mandioca, com duas rodas, duas prensas, uma de um furo e outra de dois, e um caixão de coar farinha. A existência dessa estrutura mostra que boa parte da farinha que servia de sustento aos escravos que ali trabalhavam um dia foi produzida na própria armação. Por fim, outro armazém e uma casa, que, segundo o inventariante, serviu como engenho de cana, mas que já se encontrava desativado em 1816. Isso sugere que o cultivo de cana talvez estivesse entre as funções dos habitantes da armação, mas certamente estava o beneficiamento para produção de açúcar e, talvez, aguardente.

Naquele momento, foram inventariadas apenas duas plantações: 430 laranjeiras e 80 pés de café. Seus frutos serviam para o sustento dos que ali trabalhavam, principalmente os escravos, e talvez também fossem vendidos como excedente ou trocados por outros produtos de necessidade. É notável, no entanto, que não houvesse ali plantação de cana ou de mandioca. ${ }^{10}$

Havia duas senzalas na Armação da Lagoinha: uma próxima à estrutura de beneficiamento do azeite e uma na Ilha do Campeche. A primeira era uma sequência de casas com 400 palmos de frente e 27 de fundo, levantada sobre pilares, como a capela, e dividida em 13 casas para feitores e escravos, de pau a pique, pedra e cal. Tudo isso era calculado pela obra do pedreiro em $403 \$ 000$ (quatrocentos e três mil-réis) e pela obra do carpinteiro em $326 \$ 000$ réis, num total de $729 \$ 000$ réis. A segunda senzala, de estrutura menor, consistia em uma casa com 34 palmos de frente e 30 de fundo, sobre pilares, com paredes de pau a pique. Era dividida em apenas dois quartos e calculada pela obra de pedreiro em $40 \$ 000$ e de carpinteiro em $35 \$ 000$, num total de $75 \$ 000$. As senzalas da Armação da Lagoinha, juntamente com a senzala da Armação da Piedade, eram as maiores das armações do Brasil Meridional.

10 Ibidem. 
O inventário de 1816 listava 46 escravos, todos homens (ver Tabela 2.1). Foram separados em dois grupos: o dos que tinham valor e o dos que, em razão de doenças crônicas, mutilações ou idade avançada - 18 indivíduos -, foram classificados como "sem valor". Foram ordenados por ordem alfabética, identificados por nome e nação, além da ocupação na Armação, estado de saúde e aptidão para o trabalho. O fato de muitos estarem inaptos para o trabalho confirma o abandono da armação no período em que o monopólio foi abolido. É notável que 37 dos 46 escravos listados fossem africanos, e ainda mais, que quase um terço fosse da África ocidental, região conhecida como Costa da Mina, com a qual os comerciantes baianos mantinham intenso tráfico. Isso talvez indique que a administração das armações meridionais tenha adquirido escravos na Bahia, ou ainda, que tivesse ligação com a administração das armações baianas e tenha transferido escravos com experiência para o estabelecimento das armações catarinenses. ${ }^{11}$

Tabela 2.1 - Lista nominal dos escravos da Armação da Lagoinha em 1816

\begin{tabular}{l|l|l|c|c|c}
\hline \multicolumn{1}{c|}{ Nome } & \multicolumn{1}{c|}{ Origem } & \multicolumn{1}{c|}{ Ofício } & $\begin{array}{c}\text { Condição de } \\
\text { Saúde }\end{array}$ & Idade & Valor \\
\hline Antônio & Congo & Falquejador & - & 35 & $115 \$ 200$ \\
\hline André & Moçambique & \multicolumn{1}{c}{-} & Doente & 56 & $51 \$ 200$ \\
\hline Antônio Jacinto & Mina & Cortador de açougue & Maníaco & 64 & $51 \$ 600$ \\
\hline Bernardo & Mina & Chacoteiro & - & 70 & $12 \$ 800$ \\
\hline Caetano & Benguela & - & - & 68 & $12 \$ 800$ \\
\hline Caetano & Agumi & - & - & 78 & $12 \$ 800$ \\
\hline Domingos & Crioulo & Mestre de azeite & Doente & 60 & $12 \$ 000$ \\
\hline Domingos & Moçambique & Remeiro & - & 61 & $50 \$ 000$ \\
\hline Francisco & Benguela & Falquejador & $\begin{array}{c}\text { Um braço } \\
\text { quebrado }\end{array}$ & 46 & $32 \$ 000$ \\
\hline Felippe & Mina & Gancheiro & - & 80 & $8 \$ 000$ \\
\hline Joaquim & Magume & $\begin{array}{l}\text { Cortador de cima da } \\
\text { baleia }\end{array}$ & Doente & 66 & $19 \$ 000$ \\
\hline Ignácio & Mina & & - & 71 & $12 \$ 800$ \\
\hline João & Rebolo & Chacoteiro & - & 66 & $38 \$ 400$ \\
\hline Joaquim & Cabinda & Remeiro & - & 68 & $16 \$ 000$ \\
\hline Jorge & Mina & Chacoteiro & - & 70 & $16 \$ 000$ \\
\hline
\end{tabular}

11 Ver CASTELLUCCI JUNIOR, 2009. 


\begin{tabular}{|c|c|c|c|c|c|}
\hline João & Cabinda & $\begin{array}{l}\text { Remeiro e aprendiz de } \\
\text { carpinteiro }\end{array}$ & - & 46 & $96 \$ 000$ \\
\hline Joaquim & Molumbo & Pedreiro & Doente & 62 & $40 \$ 000$ \\
\hline Jeronimo & Mina & Chacoteiro & - & 68 & $12 \$ 800$ \\
\hline José & Mina & Remeiro & - & 72 & $10 \$ 000$ \\
\hline João & Mina & - & - & 63 & $64 \$ 000$ \\
\hline João & Agumi & - & - & 66 & $12 \$ 800$ \\
\hline$\underline{\text { Luiz }}$ & Crioulo & - & - & 56 & $51 \$ 200$ \\
\hline Manoel & Congo & - & - & 73 & $10 \$ 000$ \\
\hline Paulo & - & Mestre de azeite & - & 68 & $12 \$ 800$ \\
\hline Pedro & Mogumbe & Remeiro & - & 66 & $64 \$ 000$ \\
\hline Thomaz & Camundá & Remeiro & - & 68 & $60 \$ 000$ \\
\hline José & - & Mestre de azeite & - & 64 & $16 \$ 000$ \\
\hline Xavier & Benguela & Remeiro & - & 46 & $76 \$ 800$ \\
\hline Antônio José & - & Mestre de azeite & - & 59 & - \\
\hline André & - & - & \begin{tabular}{|l|} 
Torto e \\
decrépito
\end{tabular} & 71 & - \\
\hline Cristovão & Molumbo & - & Doente & 66 & - \\
\hline Francisco & Rebolo & - & Decrépito & 78 & - \\
\hline Francisco & - & - & Doente & 68 & - \\
\hline Gonçalo & Mina & - & Decrépito & 78 & - \\
\hline José & Quisamia & - & - & 80 & - \\
\hline José Chico & - & - & - & 80 & - \\
\hline Joaquim & - & Canoa & Doente & 68 & - \\
\hline Matheus & - & Contramestre & Doente & 79 & - \\
\hline Miguel & Benguela & - & Doente & 60 & - \\
\hline Matheus & Rebolo & - & $\begin{array}{l}\text { Com um pé } \\
\text { cortado }\end{array}$ & 65 & - \\
\hline Manuel & Agumi & - & $\begin{array}{l}\text { Paralítico } \\
\text { e sem um } \\
\text { braço }\end{array}$ & 68 & - \\
\hline Sebastião & Mina & - & Asmático & 70 & - \\
\hline Salvador & - & - & Doente & 70 & - \\
\hline Salvador & Mina & Gancheiro & Cego & 66 & - \\
\hline Vitorino & Benguela & - & \begin{tabular}{|l|}
$\begin{array}{l}\text { Moléstia } \\
\text { crônica }\end{array}$ \\
\end{tabular} & 66 & - \\
\hline Xavier & Benguela & - & Asmático & 46 & - \\
\hline
\end{tabular}

Fonte: ANRJ, Inventário da Armação da Lagoinha. 
É interessante perceber que todos os escravos arrolados no inventário eram do sexo masculino. Por um lado, o trabalho na armação era predominantemente masculino - pesado, como no caso dos remeiros ou dos falquejadores, ou especializado, como no caso dos mestres de açúcar. Por outro lado, essa "fotografia" do inventário é bastante parcial. Como veremos adiante, havia um intercâmbio de mulheres, homens e crianças entre as armações do contrato. Algum fator conjuntural ou sazonal fez com que as mulheres e crianças pertencentes ao contrato da administração da pesca da baleia fossem arroladas no inventário de outra armação da região meridional. Ainda assim, a idade avançada dos escravos que permaneceram na armação demonstra o baixo crescimento vegetativo desta população e mesmo a ausência de novos escravos nos 15 anos anteriores. Â exceção de um, todos os escravos da armação arrolados tinham mais de 40 anos; mais de dois terços tinham mais de 60 anos de idade. Marcante ainda é percorrer a lista observando o registro das condições de saúde: havia os doentes, mas que ainda estavam aptos para o trabalho, e os incapacitados por doenças respiratórias (dois "asmáticos") ou condições certamente decorrentes de trabalho pesado ("com um pé cortado", "torto e decrépito", "paralítico e sem um braço"). José Chico e José Quissamia foram, aparentemente, aposentados por idade: ambos com 80 anos e sem registro de função nem de doença. Impressiona, de qualquer forma, o número de escravos com idade avançada ainda na ativa.

Um desses homens era José, que já contava 72 anos de idade e que, escravizado na costa ocidental africana, foi vendido para trabalhar em terras brasileiras. Apesar de idoso no momento do inventário, é certo que por muito tempo José exerceu importante função naquela propriedade, remando as embarcações pela região da Ilha de Santa Catarina em busca das baleias que seriam sacrificadas e aproveitadas no desenvolvimento dos mais diferentes produtos. Por muitos anos, José foi remeiro. Desempenhou outras funções no cotidiano da Armação, mas essa era a sua especialidade.

Cada etapa do trabalho de caça da baleia, até a extração de seu óleo, era exercida por um grupo de escravos, que juntamente com alguns trabalhadores livres, contratados para funções especificas, desempenhavam suas funções para que o trabalho na Armação fosse executado com sucesso. 
Apesar do estado de decadência das armações, o cotidiano se mantinha. O dia começava cedo no sul da Ilha de Santa Catarina. Entre os meses de maio e setembro, logo que o sol nascia, os escravos saíam de suas senzalas, no frio do inverno que predomina na região. Uns seguiam em direção ao mar, enquanto outros ficavam em terra para exercer suas funções na armação. Era nesses meses de inverno que as baleias fêmeas procuravam as águas tranquilas do litoral meridional da colônia para amamentar seus filhotes, o que as tornava mais vulneráveis à captura.

O trabalho não era fácil, e os trabalhadores viviam em constante situação de risco. Algumas vezes, remeiros e arpoadores passavam longos períodos no mar à espera de algum animal. As embarcações utilizadas não eram grandes e não raras vezes afundavam, seguindo o mergulho da baleia antes que desse tempo de se romper a corda do arpão. ${ }^{12}$ Por esse motivo, antes de seguirem para o mar, os barcos, seus tripulantes e os apetrechos eram abençoados pelo padre da armação; aí então, "deslizavam pela rampa de pedra do cais da armação e flutuavam na água mansa da enseada". ${ }^{13}$

Uma vez avistado o animal, os remadores - em geral, dez a doze homens, quase todos escravos - se posicionavam e começavam a remar. À frente, o baleeiro, ou arpoador, carregava um arpão pesado de ferro. De pé, se firmava e equilibrava, conduzindo o barco no itinerário da caça. A baleia se movimentava, mas era seguida incansavelmente. Se o animal estivesse acompanhado de seu filhote, o abate seria mais fácil, pois se atingindo o pequeno animal, era bem provável que a baleiamãe fosse ao seu encontro e se transformasse em presa fácil. Sendo assim, primeiramente o arpoador acertava o lombo do filhote e o trazia para rente à embarcação. Com a aproximação da mãe, esta era então capturada. Caso não houvesse filhotes, o animal era perseguido até a aproximação do arpoador, que arremessava a lança em sua direção - a função de arpoador era exercida sempre por trabalhadores livres. Arpoado o animal, baixavam-se as velas, se recolhiam e suspendiam os remos. A corda que prendia o arpão era atada à ponta extrema da proa

\footnotetext{
12 SPIX; MARTIUS, 1981, p. 139.

13 ELLIS, 1969, p. 113.
} 
da embarcação, que seguia o animal ensanguentado. Morta, a baleia era rebocada por um cabo atado à sua cauda e puxada pela baleeira até o local mais raso da praia. ${ }^{14}$

Uma canoa partia ao encontro do baleeiro a fim de conduzir o animal morto até a praia ou até um dos trapiches. Anunciada a chegada do animal, a força dos trabalhadores de terra era acionada, para que a baleia fosse retirada da água, sempre com a ajuda das marés, por conta do peso do animal. ${ }^{15}$ Um corte diagonal feito por "cortadores de cima da baleia" abria o animal da cabeça à cauda. Iniciava-se assim o esquartejamento ou desmancho do cetáceo. Chacoteiros e retalhadores faziam grandes cortes quadrados para a retirada, em primeiro lugar, do toucinho para a feitura do óleo. ${ }^{16}$ Os retalhos de toucinho eram removidos pelos trabalhadores até o engenho de frigir baleias, onde eram separados da pele, picados e lançados em caldeiras para fundir. Após a retirada da camada de gordura, a carne era retirada pelos escravos. Separada dos ossos, era dividida entre os baleeiros, que podiam usá-la como alimento ou vender para os homens livres pobres da região. Em períodos de falta de carne seca, esta era também utilizada para alimentar a escravaria da armação. Apesar de pouco saborosa, não era desdenhada por aqueles que não possuíam outro tipo de alimento. ${ }^{17}$ As barbatanas retiradas do maxilar superior do animal também eram aproveitadas. Após serem limpas, eram colocadas em tanques apropriados. Depois de secas ao sol, eram enfardadas, armazenadas e seguiam para o Rio de Janeiro, de onde partiam ao seu destino final, a Europa. Lá, era terminado o processo de preparo, para mais tarde serem revendidas para a confecção de peças de indumentárias femininas e masculinas. ${ }^{18}$

Quando era frustrada a tentativa de retirada do animal da água, os trabalhadores o retalhavam dentro da água, em uma luta incansável. Ou, na época de safras abundantes, eram abandonados ali mesmo, sem ser aproveitados. ${ }^{19}$ Supervisionando o serviço de desmancho e corte da baleia, estava um homem livre, o feitor da praia, que era subordinado a

\footnotetext{
SPIX; MARTIUS, 1981, p. 139.

15 ELLIS, 1969, p. 119.

16 Ibidem, p. 120.

17 Ibidem, p. 121.

18 Ibidem.

19 Ibidem, p. 121-124.
} 
outro homem livre, o feitor-mor. Este último também era responsável pela administração do beneficiamento do óleo da baleia. As funções de cortar e conduzir o toucinho eram exercidas essencialmente por escravos. Coordenando a produção do óleo, estava o mestre de azeite. Função mais especializada que as demais, na Armação da Lagoinha, era exercida por Domingos, um cativo crioulo, e Paulo, José e Antônio José, cuja origem não foi registrada, talvez por possuírem tratamento diferenciado com relação aos cativos africanos. Preparado o azeite, este era conduzido para tanques nos quais seria armazenado e posteriormente distribuído.

Como é possível perceber pela descrição das atividades de caça e beneficiamento do óleo, os escravos desenvolviam as mais diversas funções na armação, desde remar em alto mar a processar o azeite na estrutura montada em terra firme. As principais funções identificadas no inventário em análise eram as de remeiro, falquejador, cortador de açougue, chacoteiro, mestre de azeite, gancheiro, cortador de cima da baleia, aprendiz de carpinteiro e pedreiro.

\section{A divisão das tarefas e arranjos de trabalho livre e escravo}

A mão de obra na Armação da Lagoinha, assim como nas fazendas de cana de açúcar do Nordeste, misturou trabalhadores remunerados e escravos, fossem alugados ou comprados no mercado de escravos. Muito embora os trabalhadores escravizados realizassem a maioria dos trabalhos na armação, para algumas tarefas especializadas contratavam-se trabalhadores livres ou mesmo libertos. Os registros da administração da armação entre 1816 e 1817 permitem observar vários aspectos do seu funcionamento cotidiano, entre eles, o dos arranjos de trabalho com trabalhadores livres e a aquisição de alimentos destinados aos trabalhadores.

Havia duas formas de contrato. Para tarefas que se estendiam durante todo o ano, empregavam-se trabalhadores que recebiam salários mensais fixos. Assalariados eram os feitores e arpoadores, trabalhos considerados indispensáveis na armação. Além desses, havia os jornaleiros, contratados para trabalhos temporários, conforme a necessidade da armação, e que recebiam de acordo com o serviço prestado. Havia também a figura do caixeiro, designado pelo administrador e responsável pela venda do 
óleo. O salário era atribuído conforme a função exercida. ${ }^{20} \mathrm{O}$ trabalho remunerado ultrapassava as atividades de jornaleiros e assalariados, estendendo-se a três outras categorias: administrativa, médica e religiosa. O administrador era responsável pela supervisão do trabalho na pesca, na fábrica, nas oficinas e o do resto do pessoal, além de cuidar da contabilidade e da prestação de contas para a Administração Geral da Pesca da Baleia, que tinha sede no Rio de Janeiro. Antônio Luís Pereira, administrador da Armação da Lagoinha em 1816, recebia $350 \$ 000$ réis por ano de ordenado, ou seja, quase $30 \$ 000$ mensais, e para a alimentação, $\$ 320$ réis diários. ${ }^{21}$

O cirurgião e o padre ficavam responsáveis pelos cuidados com o corpo e o espírito dos trabalhadores. Na remuneração, ambos equivaliamse, o que pode levar a crer que, para a administração, seus serviços eram de igual importância. Por exemplo, por um ano de serviços prestados, o cirurgião Felizardo Carvalho da Cunha e Silva, da Lagoinha, e o frei Pedro Antônio de Agote, que trabalhava na capela da Armação da Garopaba, recebiam um soldo de $158 \$ 400 .{ }^{22} \mathrm{Na}$ Armação da Lagoinha, os serviços religiosos ficavam a cargo do padre da igreja do Ribeirão da Ilha, já bem estruturada nesta data (1817).

Os trabalhadores livres podiam ser contratados por longo período, como no caso dos feitores, que além do pagamento pelos serviços prestados, recebiam uma importância referente ao alimento que consumiriam..$^{23}$ Por exemplo, de 01 de junho de 1816 a 15 de março de 1817, Francisco Antônio Sanches, primeiro feitor da Armação da Lagoinha, recebeu $74 \$ 413$ réis. Foi substituído por José Diniz Pereira, que ali trabalhou até 31 de maio de 1817 , e por isso recebeu $19 \$ 582$ réis. Entre 1816 e 1817, a armação contou sempre com três feitores, um padre e um médico. Simão Barbosa, que trabalhou como segundo feitor entre 01 de junho de 1816 e 31 de maio de 1817, recebeu pelos seus serviços $84 \$ 000$. Já o terceiro feitor, Gabriel de Souza Quadros, que prestou serviços à administração da armação entre 01 de junho de 1816 e 31 de maio de 1817 , recebeu $49 \$ 000$ por seus serviços. É possível

\footnotetext{
20 Ibidem, p. 109-110.

21 Ibidem.

22 Ibidem, p. 110.

23 Ibidem.
} 
perceber através das remunerações que, mesmo entre os feitores, havia uma hierarquia, sendo os seus ordenados um reflexo da posição que ocupavam e da importância que possuíam para o bom andamento do local. ${ }^{24}$ Os demais operários livres da armação eram jornaleiros, que recebiam conforme o trabalho diário: carpinteiros, calafates e pedreiros, serradores e falquejadores, funções que eram exercidas ao lado de trabalhadores escravos. Uma terceira relação de trabalho remunerado na armação se dava por contrato com os que trabalhavam nos baleeiros: arpoadores e timoneiros. Esses recebiam pelo número de baleias capturadas..$^{25}$ Segundo Ellis, tais trabalhadores livres faziam parte das populações litorâneas de pequenos agricultores e pescadores. Porém, com os anos de abandono e sem receber pelo trabalho exercido, se dispersaram, e nos quinze anos de administração da Fazenda Real, velhos soldados foram recrutados para exercer as funções mais especializadas, como a de arpoador, de comando da embarcação ou controle sobre os escravos, como feitor da propriedade. ${ }^{26}$

Os trabalhadores escravizados formavam a mão de obra permanente da armação. Alguns eram alugados de outros proprietários, apenas para o período de safra. A maioria era de propriedade do Real Contrato. No primeiro caso, o proprietário do escravo negociava com o administrador, que deveria pagar determinado valor por cada dia trabalhado; ao fim do período de safra, retornava ao poder de seu senhor. Em 1816, dois casos foram registrados. No primeiro, Dona Iria Maria de Jesus alugou um escravo de sua propriedade para a pesca, por 36 dias, ao preço de 160 réis diários; no segundo, João Tavares Ribeiro alugou, por 12 dias, um dos vários escravos que possuía. ${ }^{27} \mathrm{~A}$ idade e a função exercida por estes escravos, assim como o valor pago por seu aluguel não constam nos documentos pesquisados.

Como vimos, alguns trabalhadores recebiam o valor destinado à alimentação como um complemento do salário. No caso dos escravos, sua alimentação estava no orçamento da armação e era responsabilidade do administrador. Constava, basicamente, de farinha de mandioca e

\footnotetext{
24 Ibidem, p. 103.

25 Ibidem, p. 102-104.

26 Ibidem.

27 Ibidem, p. 102-103.
} 
charque, a mesma ração dos escravos em outras regiões do Brasil. Além disso, recebiam fumo como recompensa e aguardente como remédio. Isso consta na lista de compras feitas pelo administrador em fins de 1816 e início de 1817. Além dos dois itens que eram a base da alimentação dos escravos, houve compra de sal, em grandes quantidades, para salgar peixe. Em 1817, uma correspondência entre Jacinto Jorge dos Anjos, da administração da Piedade, e o administrador geral, que residia no Rio de Janeiro, trata do envio de sal da Armação da Piedade para a da Lagoinha, indicando também a preocupação com a alimentação dos escravos:

Serão remetidos à Lagoinha 40 alqueires de Sal que V. Sra. Manda para naquella armação de fazer a salga do peixe com que se ajude a sustentar a escravaria della, o que estimarei que se consiga. He certo que o excessivo preço em que agora o charque esta faz tremer a quem tem tanta escravatura que sustentar porem nenhum outro alimento he tão capaz de sustentar as forças de um hum escravo que todo dia esta com hum maxado na mão a cortar lenha ou coberto de suar em carregala senão a Carne Seca e por isso he melhor alimento que se pode dae a escravatura; e que me parece bem mais acertado he que quando houverem no Rio Grande as novas charqueadas mande V. Sra. Comprar huma porção de carne para remeter a esta donde se forneção as mais armações porque escuzase de dar aos negociantes o lucro que recebem no que se lhe compra. ${ }^{28}$

Pelo fato de as compras serem listadas apenas nas quantidades entregues à armação, não fornecendo a cota destinada a cada escravo, não é possível precisar a quantidade de farinha, carne seca e fumo que cada um dos cativos recebia. Possivelmente, essa cota variasse. Além disso, não consta nos documentos se os escravos recebiam a comida pronta ou os produtos para cozinhar conforme a vontade de cada um. No entanto, se pensarmos no pequeno número de escravos listados para a armação, dificilmente o administrador aceitasse desviar seus escravos para preparar seus alimentos, principalmente nos períodos de maior intensidade da pesca. É possível que alguma mulher livre desempenhasse tal tarefa. Os doentes possuíam alimentação diferenciada. No lugar da

28 ANRJ, Inventário da Armação da Lagoinha. 
carne seca, recebiam galinha e carne verde durante o tratamento. Nessa ocasião, provavam leite e açúcar branco.

Os alimentos para os escravos eram comprados, mas também produzidos na própria armação. Vimos que a armação tinha um "sítio", que contava com um engenho de farinha e um de cana-de-açúcar, onde provavelmente os escravos trabalhavam em horários pré-estabelecidos pelo administrador. É bem possível que a armação fosse autossuficiente nesses dois produtos durante a vigência do monopólio. No entanto, em 1816, no momento do inventário, tais estruturas estavam desativadas, o que motivava as compras de gêneros. Das culturas do terreno da armação, as laranjas talvez fossem consumidas, mas é quase certo que outras frutas ou legumes não inventariados compusessem a dieta dos trabalhadores. Apesar disso, ainda não foram encontrados indícios de que estes, escravizados ou livres, pudessem cultivar suas próprias roças, como era comum no arranjo de trabalho de algumas unidades escravistas.

\section{Nova fase, seguida de desmantelamento}

Em 1817, houve a assinatura de um novo contrato de arrendamento e assim, uma troca de administração. Em 16 de junho de 1817, a sumaca Fama, vinda do Rio de Janeiro com destino à Armação da Piedade trazia, além de quatro escravos, o novo administrador da Armação da Lagoinha, José Antônio de Carvalho. Ele vinha com sete pessoas de sua família e seis escravos, provavelmente seus, para ali se estabelecer. Ele trazia também um porco, quatro leitões, 54 galinhas, toucinho, presunto, linguiça, vinhos, licores, aguardente, cerveja, vinagre, açúcar de todos os tipos (branco, refinado, pérola), café, chocolate, marmelada, roscas, sequilhos, pães, manteigas, nozes, velas, feijão, farinha, ovos, entre outros itens, para sua alimentação e conforto, além de alguns itens destinados à própria armação. $\mathrm{O}$ valor de todo o carregamento de alimentos, perfumes e utensílios era de $183 \$ 320 .{ }^{29}$

Nesta fase de administração particular, houve novo investimento na aquisição de mão de obra. Inicialmente, africanos novos foram comprados

29 Ibidem, p. 94. 
pelo administrador no Rio de Janeiro. Nos anos seguintes, o crescimento se deu através do nascimento de crianças. Analisando-se os registros de batismos do Ribeirão da Ilha, foi possível perceber o registro dos novos escravos recém-chegados, assim como acompanhar o nascimento de seus filhos nos anos seguintes. No grupo de escravos boçais comprados no Rio de Janeiro, estavam 16 homens e apenas duas mulheres, mantendo-se a preferência por cativos do sexo masculino para a execução dos trabalhos na armação.

A tabela 2.2 representa duas gerações de escravos da Armação. Os africanos novos batizados em 1817, eram predominantemente do Centro-Oeste africano, de nações Congo e Cabinda, com alguns africanos da Costa Oriental (Moçambique), refletindo o mercado de escravos no Rio de Janeiro na segunda década do século XIX. ${ }^{30}$ Seus padrinhos, já veteranos no trabalho da Armação, foram adquiridos na segunda metade do século XVIII e, entre eles, havia muitos da Costa da Mina.

Além dos escravos vindos para a armação através do tráfico, é possível verificar nos registros de batismo da Freguesia do Ribeirão o nascimento de crioulos na armação. Nos registros consultados entre os anos de 1807 a 1854 (com um intervalo entre os anos de 1841 e 1846, dos quais os registros encontram-se queimados, sem condições de leitura), foi possível identificar 16 nascimentos de 1818 a 1839 , todos listados na tabela 2.3. O batismo era uma das formas mais comuns de se registrar a propriedade de um escravo. É notável que 15 dos 16 nascimentos fossem de filhos de casais formados na armação, a maioria deles legitimados na igreja. A exceção é o nascimento de Francisco, em maio de 1839, filho natural e de Vinicena, crioula, escrava do contrato da armação $\cdot{ }^{31} \mathrm{O}$ pequeno era possivelmente neto de uma das africanas pertencentes ao contrato.

FLORENTINO, 1997, p. 139.

31 ARQUIVO HISTÓRICO ECLESIÁSTICO DE SANTA CATARINA (AHESC). Livro 2 de Batismo de Escravos da Freguesia do Ribeirão da Ilha. folha 245v., assento de 10/05/1839. 
Tabela 2.2 - Lista de escravos batizados em 1817 como pertencentes ao Contrato da Armação da Lagoinha

\begin{tabular}{l|l|l|l}
\multicolumn{1}{c|}{ Nome } & \multicolumn{1}{c|}{ Nação } & \multicolumn{1}{c}{ Padrinho } & Origem/Nação \\
\hline Manoel & Congo & Joaquim & \\
\hline Antonio & Congo & Luiz & Crioulo \\
\hline Luiz & Congo & Felisberto & Crioulo \\
\hline Francisco & Congo & João & Costa da Mina \\
\hline Antonio & Congo & Francisco & Magangá \\
\hline João & Congo & Domingos & Moçambique \\
\hline Lorenzo & Congo & Xavier Gonçalves & \\
\hline Felisberto & Cabinda & Felipe & Costa da Mina \\
\hline Domingos & Congo & Joaquim & Mugumbe \\
\hline Manoel & Cabinda & João & Nagume \\
\hline Antonio & Cabinda & Caetano & Nagume \\
\hline Matheus & Cabinda & Bernardo & Costa da Mina \\
\hline Pedro & Cabinda & Jerônimo & Costa da Mina \\
\hline Joaquim & Cabinda & Pablo & \\
\hline Vicenti & Moçambique & Manoel & Nagume \\
\hline Simon & Moçambique & José Chico & \\
\hline Catharina & Congo & Luiz & Crioulo \\
\hline Luiza & Cabinda & Alberto & Crioulo \\
\hline
\end{tabular}

Os batismos foram celebrados na Capela da Lagoinha em 15/11/1817, por licença do vigário do Ribeirão. Todos os padrinhos também eram escravos do contrato, à exceção de Joaquim Mugumbe cujo estatuto não foi identificado no assento.

Fonte: ARQUIVO HISTÓRICO ECLESIÁSTICO DE SANTA CATARINA. Livro de Batismos da Freguesia de Nossa Senhora da Lapa do Ribeirão da Ilha. Livro 1 (1807-1825), fls. 101-101v.

Esses registros de batismo demonstram a presença de famílias e também a formação de laços de parentesco ritual entre os escravos do contrato, uma vez que muitos deles escolhiam seus companheiros como comadres e compadres. Mas havia interação com os escravos e libertos (provavelmente africanos) das propriedades próximas. O casal Maria e José Cabinda, por exemplo, escolheu para madrinha da pequena Maria a preta forra Luiza e para padrinho, Manoel, escravo de Vicente Martins. ${ }^{32}$ Luiza e José, chegados à armação na última compra feita em 1817, ambos

32 AHESC. Livro 1 de Batismo de Escravos da Freguesia do Ribeirão da Ilha. fl. 122, assento de 13/12/1818. 
ditos de nação Cabinda, tiveram três filhos registrados entre 1818 e 1839: José (outubro de 1820); Jacinta (dezembro de 1823); e Thomaz (outubro de 1825). No entanto, não é possível saber se já eram cônjuges na África ou se a união aconteceu durante o período de convivência na armação, o que é mais provável. O fato é que os três filhos foram registrados como legítimos. José teve por padrinhos José Benguela e Esperança Congo, ambos escravos do contrato; Jacinta teve como padrinhos um casal de escravos do Alferes José Pires, João e Mariana; e Thomaz teve por padrinho Otanásio, companheiro de trabalho de seu pai, e por madrinha, Nossa Senhora do Rosário. ${ }^{33}$

Outro casal, Catarina e Francisco, ambos ditos do Congo e que haviam chegado à Armação em 1817, tiveram dois filhos nesse período: Jacinto (1822) e Luiza (1824), ambos registrados como filhos legítimos. Catarina e Francisco escolheram compadres fora do âmbito da armação. Jacinto teve por padrinho Manoel Rebolo, escravo do major Antônio Luiz Pereira, e por madrinha, Maria, escrava de Clemêncio Martinez; já Luiza teve por padrinho Luiz, escravo de João Gonçalves, e por madrinha, Sant'Anna. ${ }^{34} \mathrm{~A}$ união destes casais e a legitimidade das crianças apontam o incentivo aos casamentos por parte do administrador. Nota-se na tabela 2.3 que havia mais mulheres na Armação da Lagoinha do que até então registrado. Talvez tenham chegado do Rio já batizadas ou, o que é mais provável, pertencessem a uma das outras armações, como a da Piedade, onde havia uma dinâmica comunidade escrava. ${ }^{35}$

Mesmo com a tentativa de revitalização das armações, iniciada em 1816, estas não venceram a concorrência dos barcos norte-americanos, que caçavam baleias e beneficiavam o óleo em alto-mar. ${ }^{36}$ Com a rescisão do contrato em 1825, cada armação teve um destino diferente. A da Lagoinha e a da Piedade foram destinadas ao serviço da nação. Em fins de 1831, a armação da Lagoinha foi arrematada por Veríssimo Mendes Viana e sócios. Naquele momento, além da depreciação dos bens, falta

33 AHESC. Livro 1 de Batismo de Escravos da Freguesia do Ribeirão da Ilha. assento de 22/10/1820 (fl. 152v.); assento de 28/12/1823 (fl. 202v.); Livro 2, assento 01/11/1825 (fl. 16).

34 AHESC. Livros 1 de Batismo de Escravos da Freguesia do Ribeirão da Ilha. assento de 12/07/1822 (fl. 183); assento de 18/06/1824 (fl. 209v.).

35 CAMPOS, 2002.

36 COMERLATO, 2004. 
de utensílios e destruição de quase 7000 pés de café, ainda lhe faltavam 175 braças do terreno. ${ }^{37}$ Não conseguimos ainda verificar o que aconteceu com os escravos. É provável que tenham vivido um período de grande insegurança quanto ao futuro e, possivelmente, sido remanejados ou vendidos, sofrendo a separação das famílias.

Em 1843, o território da armação já se encontrava desmembrado. Muitas famílias viviam no Pântano do Sul, onde cultivavam roças e viviam de pesca. No espaço da armação propriamente dito, havia três "fogos": o do crioulo Severino Antônio, de 45 anos, que vivia com a mulher, um filho e Albino, escravo Congo de 16 anos; o da crioula Lexandra Rosa, de 28 anos, aparentemente solteira, com quatro filhos pequenos; e o do alemão Henrique Silveira, que lá vivia com sua mulher, um filho e doze escravos. (ver Tabela 2.4) Não é certo que algum deles fosse remanescente dos escravos do contrato, mas é provável, uma vez que Henrique foi registrado como feitor. ${ }^{38}$ Em 1843, a Freguesia do Ribeirão, mais voltada para a Baía Sul do que para o mar aberto, tinha se consolidado como a mais populosa da ilha de Santa Catarina e grande produtora de farinha de mandioca. Como se vê, a partir dos dados de um recenseamento de 1843 , apresentados nas tabelas 2.5 e 2.6, de sua população de 2331 almas, 633 viviam na escravidão, isto é, mais de um em cada quatro habitantes. Boa parte dos escravos era africana. De cada 10 unidades familiares, quatro tinham escravos, em geral, de um a cinco.

Quando a administração das armações baleeiras entrou em decadência, Santa Catarina vivia uma forte expansão da escravidão, porém, ligada a outra atividade econômica: a produção de alimentos, que não requeria unidades produtivas tão grandes ou complexas quanto uma armação baleeira.

\section{Fontes}

\section{ARQUIVO HISTÓRICO ECLESIÁSTICO DE SANTA CATARINA}

Livro 1 de Batismo de Escravos da Freguesia do Ribeirão da Ilha (1807-1825).

Livro 2 de Batismo de Escravos da Freguesia do Ribeirão da Ilha (1825-1841).

37 ELLIS, 1969, p. 196.

38 CARTÓRIO DO 1 TABELIONATO DE NOTAS DO RIBEIRÃO DA ILHA. Livro de Matrícula dos habitantes do Ribeirão da Ilha, 1843, fls. 113-116. 
Junta do Comércio. Real Administração da Pesca das Baleias. Inventário da Armação da Lagoinha. Caixa 360.

CARTÓRIO DO 1ํ TABELIONATO DE NOTAS DO RIBEIRÃO DA ILHA Livro de Matrícula dos habitantes do Ribeirão da Ilha, 1843.

\section{Referências}

CAMPOS, Fábio Israel Vieira de. A mão de obra utilizada para a caça da baleia no litoral Catarinense; Armação Grande ou de Nossa Senhora da Piedade, 1746-1836. Trabalho de Conclusão de Curso (Graduação em História). CFH, Universidade Federal de Santa Catarina, 2002.

CASTELLUCCI JUNIOR, Wellington. Caçadores de baleia: armações, arpoadores, atravessadores e outros sujeitos envolvidos nos negócios do cetáceo no Brasil. São Paulo: Annablume, 2009.

COMERLATO, Fabiana. O Declínio da Pesca da Baleia nas Armações Catarinenses. Fronteiras. Revista Catarinense de História, Florianópolis, v. 10, 2004. p. 65-73

ELLIS, Myriam. A Baleia no Brasil Colonial. São Paulo: Melhoramentos, 1969.

FLORENTINO, Manolo. Em costas negras: uma história do tráfico de escravos entre a África e o Rio de Janeiro. São Paulo: Companhia das Letras, 1997.

SPIX; MARTIUS. Viagem pelo Brasil. Belo Horizonte: Itatiaia; São Paulo: Edusp, 1981. 


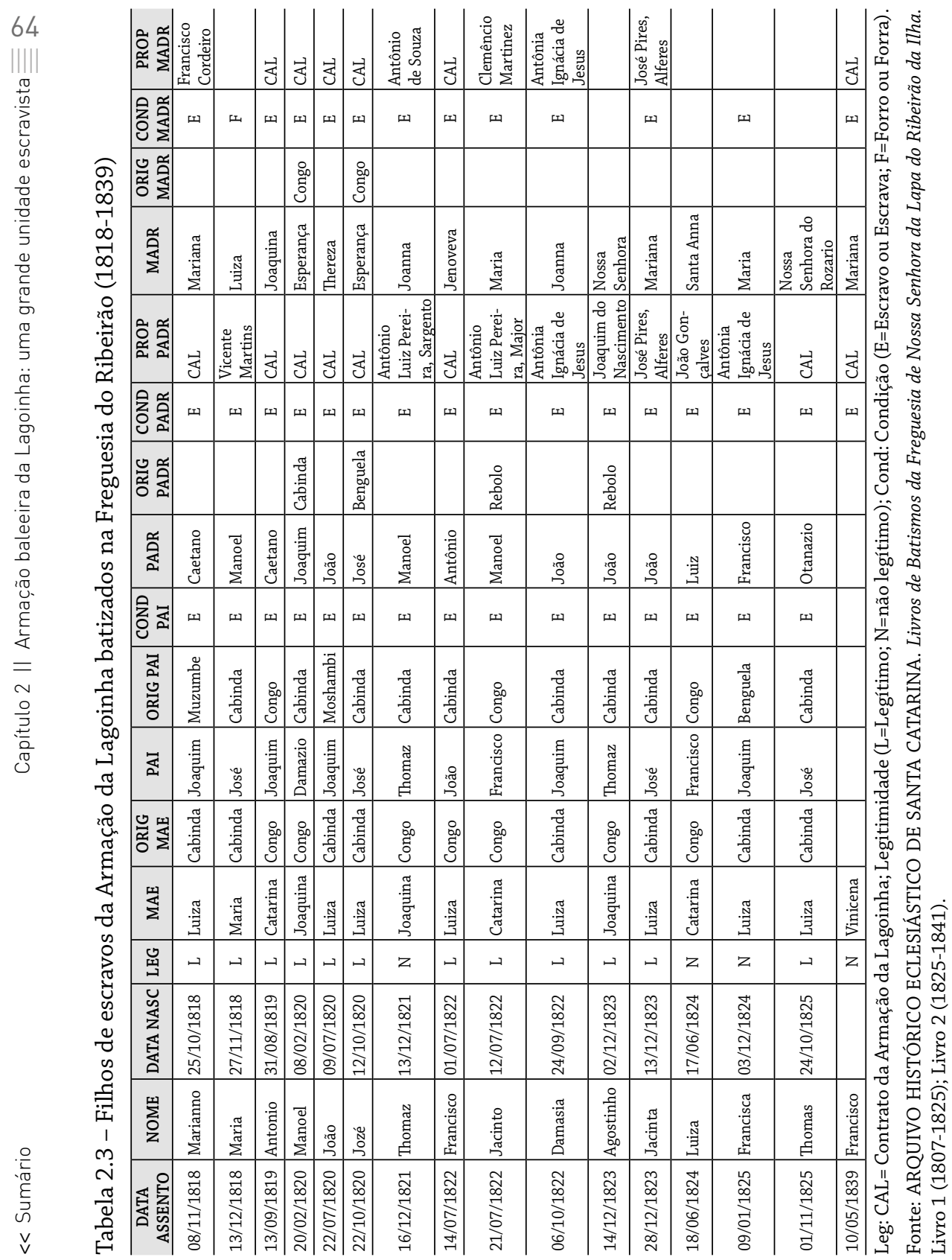


Tabela 2.4 - Habitantes da Armação da Lagoinha em 1843

\begin{tabular}{|c|c|c|c|c|c|c|c|}
\hline Nome & Pos. & Idade & Cond. & $\begin{array}{c}\text { Estado } \\
\text { Civil }\end{array}$ & Ofício & Origem & Obs. \\
\hline Henrique Silveira & $C$ & 33 & Liv & Casado & Feitor & Alemanha & \\
\hline Clarinda Luiza & M & 32 & Liv & Casada & & & \\
\hline João & $\mathrm{F}$ & 11 & Liv & & & & \\
\hline Joaquina & $\mathrm{E}$ & 34 & Esc & Solteira & & Brasil & Crioula \\
\hline Hariel & $E$ & 72 & Esc & & & Ganguela & \\
\hline André & $E$ & 62 & Esc & & & Mina & \\
\hline Antônio & $\mathrm{E}$ & 62 & Esc & & & Congo & \\
\hline Joaquim & $E$ & 52 & Esc & & & Angola & \\
\hline Francisco & $\mathrm{E}$ & 49 & Esc & & & Congo & \\
\hline Marcellino & $\mathrm{E}$ & 22 & Esc & & & Brasil & Crioulo \\
\hline Hariel & E & 19 & Esc & & & Brasil & Crioulo \\
\hline João & $\mathrm{E}$ & 18 & Esc & & & Brasil & Crioulo \\
\hline Joana & E & 54 & Esc & & & Cabinda & \\
\hline Luzia & $\mathrm{E}$ & 50 & Esc & & & Cabinda & \\
\hline Maximiana & $E$ & 35 & Esc & & & Brasil & Crioulo \\
\hline Severino Antônio & C & 45 & Liv & Casado & Carper & $\begin{array}{l}\text { Brasil - Sta } \\
\text { Catarina }\end{array}$ & Crioulo \\
\hline Deoniza Maria & $\mathrm{M}$ & 26 & Liv & Casado & & & \\
\hline Manoel & $\mathrm{F}$ & 12 & Liv & & & & \\
\hline Albino & $E$ & 16 & Esc & Solteiro & & Congo & \\
\hline Lexandra Roza & C & 28 & Liv & Solteira & & $\begin{array}{l}\text { Brasil - Sta } \\
\text { Catarina }\end{array}$ & Crioulo \\
\hline João & $\mathrm{F}$ & 2 & Liv & & & & \\
\hline Deolinda & $\mathrm{F}$ & 9 & Liv & & & & \\
\hline Maria & $\mathrm{F}$ & 3 & Liv & & & & \\
\hline Jacintha & F & 1 & Liv & & & & \\
\hline
\end{tabular}

$\mathrm{P}=$ Posição na unidade produtiva ( $\mathrm{C}=$ Chefe do Fogo; $\mathrm{M}=$ Mulher; F=Filho; $\mathrm{E}=$ Escravo); Cond=Condição (Livre ou Escravo).

Fonte: CARTÓRIO DO 1ำTABELIONATO DE NOTAS DO RIBEIRÃO DA ILHA, Livro de Matrícula dos habitantes do Ribeirão da Ilha, 1843. 
66 Tabela 2.5 - Distribuição da população do Ribeirão da Ilha conforme posição nos fogos (1843)

\begin{tabular}{l|c|r|r|r}
\hline & Homens & Mulheres & Total & \% \\
\hline Chefes de família & 292 & 76 & 368 & 15,8 \\
\hline Esposas & & 264 & 264 & 11,3 \\
\hline Filhos & 465 & 515 & 980 & 42,0 \\
\hline Agregados & 32 & 44 & 76 & 3,3 \\
\hline Filhos de agregados & 2 & 4 & 6 & 0,3 \\
\hline Escravos & 406 & 227 & 633 & 27,2 \\
\hline Incerto & 0 & 4 & 4 & 0,2 \\
\hline Total & 1197 & 1134 & 2331 & 100 \\
\hline
\end{tabular}

Fonte: CARTÓRIO DO 1 TABELIONATO DE NOTAS DO RIBEIRÃO DA ILHA, Livro de Matrícula dos habitantes do Ribeirão da Ilha, 1843.

Tabela 2.6 - Posse escrava no Ribeirão da Ilha (1843)

\begin{tabular}{c|c|c|c}
\hline $\begin{array}{c}\text { Posse } \\
\text { escrava }\end{array}$ & $\begin{array}{c}\text { Número de } \\
\text { famílias } \\
\text { (fogos) }\end{array}$ & $\begin{array}{c}\text { Distribuição da } \\
\text { propriedade escrava na } \\
\text { população }\end{array}$ & $\begin{array}{c}\text { Concentração da } \\
\text { propriedade escrava } \\
\text { entre proprietários }\end{array}$ \\
\hline 0 & 218 & $60 \%$ & \\
\hline $1-5$ & 112 & & $76 \%$ \\
\hline $6-10$ & 23 & $40 \%$ & $16,5 \%$ \\
\cline { 1 - 1 } & 11 & & $7,5 \%$ \\
\hline
\end{tabular}

FFonte: CARTÓRIO DO 1 TABELIONATO DE NOTAS DO RIBEIRÃO DA ILHA, Livro de Matrícula dos habitantes do Ribeirão da Ilha, 1843. 


\section{|| Capítulo 3 ||}

\section{Escravidão nos engenhos de farinha da Lagoa da Conceição}

Ana Carla Bastos

Era 1880. Naquele dia nove do mês de janeiro, a senhora Sipriana Roza de Jesus chamara o escrivão até sua casa, uma propriedade localizada no Canto da Lagoa, para que ele registrasse em seu livro de notas sua vontade de libertar dois escravos que lhe pertenciam: Roza e Manoel. Roza, então com 36 anos de idade, era a mãe de Manoel, ao qual dera à luz no ano de 1863. Portanto, Manoel nascera escravo na Freguesia da Lagoa da Conceição e tinha 17 anos. Em 1880 recebia, junto com sua mãe, a promessa de um dia deixar de ser escravo e ser dono de si mesmo. Seria, conforme ditou Sipriana Roza de Jesus ao escrivão, no dia em que ela morresse. Até que isso acontecesse, ambos deveriam acompanhar e servir Sipriana Roza de Jesus, segundo as palavras que deixou registradas, "enquanto viva for". ${ }^{1}$

Servir ao seu proprietário com a promessa de tornar-se livre após sua morte foi um dos arranjos mais comuns aceitos pelos escravos que viveram na Lagoa da Conceição para obter a liberdade, conforme podemos verificar pelas "cartas de liberdade" ou "cartas de alforria" registradas no cartório da freguesia, entre 1840 e 1888. Tais documentos nos permitem adentrar a vida de proprietários, escravos e futuros libertos que viveram na Lagoa da Conceição e vivenciaram a escravidão no seu dia a dia. Nascidos na própria freguesia ou para ali trazidos, da África ou de outras

1 CARTÓRIO DA LAGOA DA CONCEIÇÃO, FLORIANÓPOLIS. Livro de Notas $n^{\circ}$ 5, folhas 22v-24. Registro de 9/1/1880. 
localidades do país, a história da vida destes escravos e futuros libertos não está dissociada da história de seus proprietários. Pelo contrário, estão entrelaçadas desde a origem da Freguesia da Lagoa, o que nos remete diretamente à segunda metade do século XVIII.

\section{A freguesia de Nossa Senhora da Conceição da Lagoa}

A Freguesia de Nossa Senhora da Conceição da Lagoa situa-se na costa leste da ilha de Santa Catarina - no sul do Brasil - junto a uma lagoa de água salgada, calma e muito piscosa. Fundada por volta de 1750, é uma das mais antigas da ilha. Por esse tempo, a única povoação ali existente era a vila de Nossa Senhora do Desterro, fundada pelo vicentista Francisco Dias Velho Monteiro. Nessa primeira fase de ocupação da ilha - entre meados do século XVII e meados do XVIII - os portugueses instalaram-se, dependendo do apoio de índios aldeados e de poucos escravos africanos, para sondar o potencial do território, como fizeram em outras regiões fronteiriças. ${ }^{2}$

A fundação da Freguesia da Lagoa insere-se na segunda fase de ocupação da Ilha de Santa Catarina, iniciada em meados do século XVIII, quando o litoral catarinense foi objeto de projeto estratégico de colonização e exploração, passando a integrar o circuito atlântico. Após o povoado de Nossa Senhora do Desterro ser alçado à condição de vila em 1726, e Santa Catarina à condição de capitania em 1738, o governo foi chefiado pelo Brigadeiro José da Silva Paes. Sua primeira medida foi colocar em prática um plano de fortificação da Ilha de Santa Catarina, aliado à vinda de açorianos e madeirenses para ocupá-la, com o objetivo de servir de base e apoio logístico para a conquista portuguesa da Bacia do Prata. ${ }^{3}$

As primeiras levas de imigrantes chegaram a partir de 1748 e se estabeleceram na Vila do Desterro e seus arredores. Cumprindo a determinação real de escolher na mesma ilha "os sítios mais propícios para fundar lugares, em cada um dos quais se estabeleçam pouco mais ou menos sessenta casais dos que forem chegando", foi durante

\footnotetext{
MAMIGONIAN, 2006, p. 617.

3 Ibidem, p. 618.
} 
o governo de Manoel Escudeiro Ferreira de Souza que se fundou a Freguesia de Nossa Senhora da Conceição da Lagoa, sob os auspícios da padroeira que também emprestava seu nome a um dos navios que fizera o transporte dos colonos, a embarcação Nossa Senhora da Conceição e Porto Seguro. ${ }^{4}$

Aos interessados em emigrar para o Brasil foram oferecidas vantagens, encontradas no Edital de Recrutamento, tais como a doação, para cada casal, de uma espingarda, duas enxadas, um machado, duas facas, duas tesouras, dois alqueires de sementes, duas vacas, uma égua, uma porção de terra e farinha para o sustento durante um ano. São poucos os relatos sobre a vida destes camponeses imigrantes durante os primeiros cinquenta anos. Indícios revelam que foram tempos difíceis, fosse pelo não cumprimento das concessões de terras, animais e equipamentos prometidos, fosse pela dificuldade de adaptação aos tipos de solo e clima, não tão propícios à cultura do trigo, ao qual estavam acostumados na sua terra natal. ${ }^{5}$ Apesar do incentivo da Coroa portuguesa ao desenvolvimento de atividades estratégicas como a produção de linho cânhamo, algodão, anil, conchonilha e tabaco, o que se firmou ao longo do século XVIII foi mesmo a produção de alimentos, sobressaindo-se o cultivo de gêneros como mandioca, milho, cevada, centeio, feijão, açúcar e café, além de diversas frutas e hortaliças. ${ }^{6}$ Em 1755, a existência de 52 teares de linho e algodão na Freguesia da Lagoa demonstra que a tecelagem manual teve condições de se desenvolver, gerando um suprimento suficiente para atender as necessidades locais de panos e tecidos. ${ }^{7}$

Segundo o Relatório dos engenhos existentes na Capitania de Santa Catarina, elaborado em 1797 pelo então governador João Alberto de Miranda Ribeiro, foram registrados na Freguesia da Lagoa 10 fábricas de açúcar, 28 engenhocas de aguardente, 32 atafonas de moer trigo e 101 engenhos de mandioca. A julgar por estes números, fica claro que, apesar das dificuldades iniciais, a adaptação à nova terra permitiu o desenvolvimento de técnicas de transformação de produtos agrícolas, sobretudo da mandioca e da cana-de-açúcar, em produtos essenciais para

\footnotetext{
PIAZZA, 1983, p. 149.

SILVA, 2007, p. 26.

6 COELHO, 2005, p. 197-200.

7 PIAZZA, 1983, p. 63.
} 
70 a própria subsistência e às necessidades da população local e de outras regiões da colônia. ${ }^{8}$

Indícios apontam que durante a segunda metade do século XVIII, uma demanda crescente por farinha de mandioca permitiu que se estabelecesse um mercado local significativo na ilha, que era ligado ao mercado interno de abastecimento da colônia. Nesse sentido, é importante que possamos verificar de que modo a demanda por gêneros de primeira necessidade, principalmente a farinha de mandioca, ajudou a moldar a paisagem rural da Freguesia de Nossa Senhora da Conceição da Lagoa e o cotidiano dos seus moradores desde a segunda metade do século XVIII até fins do século XIX.

\section{A demanda por farinha de mandioca}

A importância da farinha de mandioca estava no fato de ela constituir o alimento principal do sustento da população brasileira. $\mathrm{O}$ historiador Bert Barickman observa para a Bahia que, por mais variada que fosse a dieta da população, o trivial dos moradores de Salvador resumiase a um pequeno número de gêneros (arroz, milho, feijão, carne, peixe) aliados à farinha de mandioca, que ocupava o papel mais importante na alimentação cotidiana. Enquanto principal fonte de calorias e a mais barata, sua escassez era sentida. ${ }^{9} \mathrm{Na}$ Ilha de Santa Catarina não foi diferente. A promessa da Coroa portuguesa de fornecer aos colonos açorianos e madeirenses a farinha necessária ao seu sustento durante $o$ primeiro ano nos dá uma pista nesta direção.

Considerando-se a importância alimentar da farinha de mandioca, vejamos brevemente a caracterização de quatro segmentos populacionais de consumo na ilha na segunda metade do século XVIII: a guarnição militar e as tropas de passagem; a população urbana; os trabalhadores e funcionários das armações baleeiras; e a população das freguesias rurais. Pouco tempo antes da chegada dos colonos açorianos e madeirenses, ocorreu a vinda de um contingente populacional ligado diretamente à construção e ocupação das fortalezas e baterias que foram sendo erguidas

\footnotetext{
SILVA, 2007, p. 28-36.

9 BARICKMAN, 2003, p. 90-91.
} 
na ilha a partir de 1739. Desde então, as tropas aquarteladas e os oficiais residentes nas fortalezas passaram a constituir um segmento militar de consumo da farinha de mandioca. Esta era armazenada no paiol da farinha, uma estrutura que fazia parte do plano de edificação de todas as fortalezas.

A elevação de Nossa Senhora do Desterro à condição de vila em 1726, e a de Santa Catarina à condição de capitania, subordinada diretamente ao Rio de Janeiro, em 1738, propiciou a formação de um núcleo administrativo que passou a configurar um segmento urbano de consumo da farinha de mandioca.

O desenvolvimento de atividades ligadas à pesca e produção do óleo de baleia, através da fundação de seis armações baleeiras no litoral catarinense, representou também, durante a segunda metade do século XVIII, um forte incremento populacional na região, inclusive no que diz respeito à presença de escravos africanos, visto que as armações eram grandes unidades escravistas. Na própria Ilha foi fundada uma, em 1772, denominada Armação da Lagoinha; localizava-se em território ao sul da Freguesia de Nossa Senhora da Conceição da Lagoa, onde anos depois surgiu a Freguesia do Ribeirão da Ilha. A primeira e principal delas era a Armação da Piedade, instalada no continente, na Freguesia de São Miguel.

Apesar da falta de estudos que avaliem precisamente de que maneira militares das fortalezas, a população urbana e a das armações supriam suas necessidades de farinha de mandioca para consumo próprio, temos notícias de que o abastecimento por meio da compra era a estratégia utilizada pelo governo para os regimentos e também os habitantes de Desterro. Frente ao aumento do preço, o governo da capitania por vezes autorizava a sua venda diretamente do produtor ao consumidor, na praia da Vila, ou que a Câmara comprasse farinha a preço de custo para revendêla aos consumidores, como forma de evitar a influência de atravessadores em tais momentos de carestia. ${ }^{10}$ Quanto às armações baleeiras, sabe-se que o consumo de farinha era suprido também pela compra do produto, embora a existência de engenhos entre as edificações do contrato das baleias demonstre que a produção nas próprias unidades existiu. ${ }^{11}$

10 CABRAL, 1972, p. 13.

11 ZIMMERMANN, 2006, p. 58-62. 
Não podemos descartar o segmento propriamente rural da população, constituído pelos moradores da Freguesia da Lagoa e dos outros núcleos populacionais circundantes: a Freguesia de Nossa Senhora das Necessidades e Santo Antônio, localizada na ilha; São Miguel, São José, Enseada do Brito e Santa Ana, localizadas no continente. É provável que esses núcleos fossem autossuficientes quanto à produção de farinha, mas dada a importância do produto no dia a dia das pessoas, admite-se a possibilidade de que recorressem também à compra ou à troca (por exemplo, se as condições climáticas não favorecessem o processo de plantio da mandioca).

Ao lado da demanda local por farinha de mandioca comercializada, considerada até certo ponto como demanda estável, podemos encontrar também a existência de uma demanda oscilante, representada por uma "população flutuante" relacionada à atividade portuária de Desterro e pelas exportações de farinha para outras capitanias e depois províncias. Desde o século XVI, a ilha servia de local de arribação para os navios que transitavam pelo Atlântico Sul. Fosse para abastecer-se de víveres básicos, fazer consertos ou cuidar dos enfermos, várias foram as embarcações, e muitas delas estrangeiras, que passaram pelo porto de Desterro. Os marinheiros e tripulantes dessas embarcações, enquanto permanecessem na ilha, além de consumirem farinha de mandioca, aproveitavam-na para suprir o estoque de provisões indispensável ao prosseguimento das viagens.

Quanto à flutuação na quantidade de farinha exportada pelo porto da vila de Desterro, destinada a atender ao consumo de trabalhadores e soldados das regiões Sul, Sudeste e Nordeste do país,

[...] em 1786, só numa embarcação, foram exportados 4 mil alqueires, para as tropas e, mal saiu ela, outra chegou para levar mais. [...] Logo no ano seguinte o Governador recomendava a Câmara que devia primeiro garantir a subsistência do povo local e só depois permitir a exportação das sobras. Havia sentido, dizia, a irregularidade na exportação, pois no ano anterior, permitida a exportação para a Bahia, Pernambuco e Ilhas (?) [sic] ficara o povo "em grande necessidade". Em 1792, tendo havido falta de farinha em Pernambuco, foi daqui que para lá seguiu o carregamento, acrescendo que foram numerosas as recomendações para que 
aqui se facilitasse também aos "moniciadores" das tropas do Rio Grande. ${ }^{12}$

Ao longo da segunda metade do século XVIII, é certo que Santa Catarina chegou a exportar farinha de mandioca para suprir a demanda baiana nos períodos em que a produção interna daquela província não foi suficiente para alimentar a população, segundo pesquisa de Barickman. ${ }^{13}$ A exportação era feita pelo comércio de cabotagem. A principal conexão de Desterro era com a praça comercial do porto do Rio de Janeiro. Em fins do século XVIII a maioria das embarcações carregadas com farinha de mandioca que adentrou o porto do Rio de Janeiro provinha de Santa Catarina. E era do Rio de Janeiro que chegavam muitos dos produtos importados encontrados nas 18 lojas de fazenda e 44 tabernas contadas na vila de Desterro em 1796, segundo o Relatório de Miranda Ribeiro. ${ }^{14}$

$\mathrm{Na}$ ilha e nos territórios adjacentes, os 769 engenhos de mandioca ao lado das 232 atafonas de moer trigo e dos quatro engenhos de pilar arroz demonstram que, em fins do século XVIII, a demanda existente por farinha comercializada foi suficiente para estruturar um mercado local, rotas do abastecimento interno da colônia e gerar uma especialização no cultivo da mandioca e na produção da farinha destinada ao abastecimento desses mercados. ${ }^{15}$ Os 101 engenhos para beneficiar mandioca existentes na Lagoa da Conceição em 1797 indicam que a freguesia estava inserida nessa esfera de abastecimento do mercado interno de farinha. ${ }^{16} \mathrm{~A}$ vinculação das propriedades agrícolas ao cultivo da mandioca e sua transformação mostram como a demanda por farinha comercializada foi capaz de moldar a paisagem social e econômica da Freguesia da Lagoa, configurando um modo de vida rural cujo cotidiano girava em torno da mandioca.

Vários autores apontam que o cultivo da mandioca, embora não fosse fácil, não exigia trabalho árduo nem muitos cuidados. Podia ser plantada em qualquer época do ano e se adaptava a vários tipos de solo,

\footnotetext{
12 CABRAL, 1972, p. 13-14.

13 BARICKMAN, 2003, p. 132.

14 CABRAL, 1972, p. 9.

15 SILVA, 2007, p. 41-60.

16 Ibidem.
} 
principalmente o arenoso, comum nas regiões litorâneas brasileiras. ${ }^{17}$ "A ferro e fogo" era como nasciam as roças: uma foice para abrir uma clareira e fogo para limpar o matagal. Em seguida, a terra não recebia adubo ou esterco, "sendo feito apenas uma 'virada' geral, à enxada, das camadas da superfície, as quais ficavam a arejar por dois ou três dias, findos os quais começam a abrir-se as covas para a 'enterra' da rama", conforme descreveu Virgílio Várzea, cronista da ilha na virada do século XX. ${ }^{18}$ As ramas eram pedaços picados de caule com 10 a 15 centímetros de comprimento, retiradas de mudas da colheita anterior. Colocadas no fundo das covas, eram cobertas com terra fofa rechegada com os pés ou enxada. No período de dois anos, em geral, esperado para se fazer a colheita, tudo o que a plantação precisava era de algumas capinas para livrá-la do mato e das ervas daninhas, além, é claro, de condições meteorológicas propícias ao seu crescimento. ${ }^{19}$ Muito mais trabalhosa era a eliminação do ácido venenoso da raiz para que se obtivesse a farinha bruta da mandioca. $\mathrm{O}$ processo envolvia pelo menos seis tarefas: raspar, lavar, ralar, prensar, peneirar e torrar. Essas tarefas eram realizadas com o auxílio de utensílios como a roda para ralar, a prensa para enxugar a massa ralada e o forno para torrar a farinha, além de instrumentos como peneiras, tachos, cochos e balaios (tipitis). Estudados pelo arqueólogo Osvaldo Paulino da Silva, os utensílios e maquinário configuravam o engenho de fabricar farinha de mandioca, que poderia ser operado unicamente com a força humana ou com o auxílio de rodas d'água ou tração animal para movimentar a roda de ralar, a prensa e a hélice para mexer a farinha enquanto ela torrava. ${ }^{20}$

A dinâmica do mercado de abastecimento inter-regional se intensificou após a transferência da Corte portuguesa para o Rio de Janeiro; e a farinha de mandioca despontaria definitivamente como o produto de maior expressão no comércio exportador da província de Santa Catarina, principalmente através do porto de Desterro. A historiadora Laura Machado Hübener destaca a força que a sua exportação alcançou na metade do século, quando comparada com outros gêneros: no período de 1851 a 1860, Desterro exportou 1.335.930 alqueires de farinha, 110.666

\footnotetext{
17 BARICKMAN, 2003, p. 272-278.

18 VÁRZEA, 1985, p. 196.

19 BARICKMAN, 2003, p. 272-278.

20 SILVA, 2007, p. 41-60.
} 
alqueires de milho e 59.216 alqueires de feijão. Apesar do ritmo instável nas exportações do produto, nos anos de 1878 e 1879, Santa Catarina era o segundo fornecedor de farinha de mandioca para o Rio de Janeiro, passando a primeiro em 1880 e 1881, posição que ocupara no início do século. ${ }^{21}$

O estudo de inventários post-mortem de moradores da Lagoa da Conceição mostra que a freguesia permaneceu conectada à dinâmica do mercado interno de abastecimento de farinha ao longo do século XIX, mantendo a especialização no cultivo da mandioca e no preparo da farinha. Coordenada pelo historiador Paulino Jesus Francisco Cardoso, a pesquisa dos 44 inventários e arrolamentos de bens registrados entre 1870 e 1880 evidenciou que 26 dos falecidos eram proprietários totais ou parciais de engenhos de farinha e/ou açúcar; em outros 18 foi possível encontrar equipamentos para guarda ou preparo de farinha, como tachos de cobre, caixas para armazenamento, além das próprias roças de mandioca. ${ }^{22}$

Analisando inventários de 1849 a 1887 na comarca de Paranaguá, o historiador José Augusto Leandro ressaltou que a existência de uma "cultura material da farinha" - atestada pela quase onipresença dos apetrechos necessários à sua fabricação - aponta para uma experiência comum compartilhada por aqueles moradores, na qual a estratégia de sobrevivência dos grupos familiares apresentava-se ligada de maneira inextricável à farinha de mandioca. ${ }^{23}$

Aliados aos dados do relatório de Miranda Ribeiro para fins do século XVIII, os dados dos inventários da década de 1870 também confirmam uma cultura material da farinha na Freguesia da Lagoa, responsável, desde a segunda metade do século XVIII e ao longo do século XIX, por um modo de vida rural, no qual o trabalho voltado à mandioca continuou a ser a sua expressão máxima.

É neste contexto rural de produção e comercialização da farinha de mandioca que podemos articular a vida de escravos como Roza e seu filho Manoel, e sua proprietária Sipriana Roza de Jesus. As fontes documentais relativas à Freguesia da Lagoa da Conceição nos revelam que o uso do trabalho cativo nessa região aconteceu logo após a fundação da freguesia.

\footnotetext{
21 HÜBENER, 1981, p. 80-87.

22 CARDOSO, 2004, p. 36-42.

23 LEANDRO, 2007, p. 261-2688.
} 
A partir da chegada de africanos novos verificada nos registros batismais na segunda metade do século XVIII, é possível identificar a fase de compra de escravos novos pelos proprietários de terras açorianos fixados na Lagoa da Conceição.

Entre os registros, foram identificados os batismos de 251 recémnascidos de mãe escrava: 110 de mãe africana, 78 de mãe crioula e 63 sem indicação de origem. A análise sugerida por Maria Helena Schweitzer ressalta que o número de africanas entre as mães dos recém-nascidos batizados nos dá uma dimensão da sua presença na Lagoa. Observase também o fato de que estas mães africanas não foram batizadas na Freguesia, indicativo de que foram compradas e trazidas para lá depois de passarem algum tempo em outro lugar, onde teriam sido batizadas. Considerando que apenas três batismos de africanos adultos recémchegados puderam ser identificados para o período, tudo indica que os proprietários da Lagoa que compraram escravos e escravas na segunda metade do século XVIII recorreram inicialmente ao mercado de crioulos ou africanos ladinos, e é possível que tenham optado preferencialmente pela aquisição de mulheres, por serem, em termos de valor, mais acessíveis que os cativos homens e poderem reproduzir. ${ }^{24}$ Essa hipótese é levantada por Barickman em estudo sobre os distritos produtores de mandioca situados no Recôncavo Baiano. Ao deparar-se com uma alta proporção de mulheres caracterizando a mão de obra escrava dos produtores de farinha - ao contrário do padrão característico de desequilíbrio entre os sexos ou o predomínio de homens em engenhos de cana-de-açúcar - o autor considera que o motivo pode estar na diferença entre os preços pagos por escravos e escravas (elas custavam de 10 a $20 \%$ menos), considerandose as rendas modestas que os lavradores de mandioca obtinham com a venda da farinha. ${ }^{25}$ Vale ressaltar que o acesso à condição de proprietário de escravos através da propriedade de um escravo do sexo feminino foi uma característica relacionada aos agricultores proprietários de poucos escravos (1-5 cativos), segundo a pesquisa de Iraci Costa e Nelson Nozoe

\footnotetext{
24 SCHWEITZER, 2006, p. 14-16.

25 BARICKMAN, 2003, p. 255.
} 
sobre a estrutura de posse escrava na vila paulista de Lorena, início dos Oitocentos. ${ }^{26}$

Os dados dos batismos na Lagoa sugerem que, ao longo dos primeiros cinquenta anos de ocupação, o cultivo diversificado dos alimentos indispensáveis à sobrevivência da família (com destaque para a produção da farinha de mandioca), além de assegurar a autossuficiência doméstica, também foi capaz de gerar excedentes que podiam ser comercializados. A renda obtida com a venda dos excedentes permitiu que algumas famílias se tornassem proprietárias de escravos; e o crescimento do número de batismos verificado década após década demonstra que foram se tornando mais propícias as condições para que se adquirissem e mantivessem escravos e escravas. Ainda pelos registros de batismos, já nas primeiras décadas do século XIX, é possível observar um incremento da aquisição de africanos novos. Enquanto antes de 1808 os batismos de africanos novos foram pouco numerosos ou pouco explícitos, depois dessa data, eles passam a ocorrer sistematicamente, como podemos observar no gráfico abaixo:

Figura 3.1 - Batismos de africanos novos por ano na Freguesia da Lagoa (18081842)

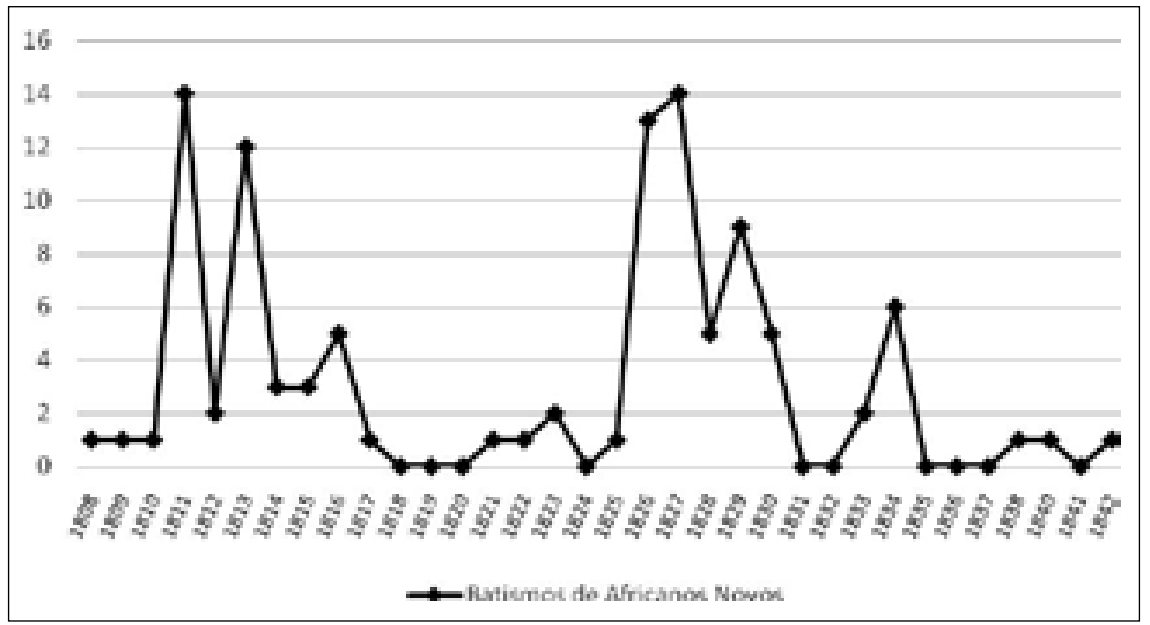

Fonte: SCHWEITZER, 2006.

26 MOTTA, 1999, p. 67-108. 
O fato de africanos novos aparecerem batizados em maior quantidade do que no século anterior, aliado ao aumento do nascimento de escravos na própria freguesia, é indicativo de que os proprietários da Lagoa, para além do investimento em escravos crioulos ou africanos ladinos, tiveram condições de diversificar sua aquisição e investir também na compra de escravos chegados diretamente da África, em sua maioria, homens adultos. Sendo a compra desses escravos feita no porto do Rio de Janeiro, parece que os proprietários da Lagoa puderam também se beneficiar da intensificação do comércio deste porto com a costa africana. ${ }^{27}$

Pesquisando inventários post-mortem da década de 1870, a historiadora Joice Farias formulou análise do padrão socioeconômico a partir da diferenciação dos falecidos segundo três faixas de fortuna: camponeses pobres, remediados e ricos. A propriedade da terra, junto da mão de obra familiar, constituía um bem comum a todos e possibilitava a subsistência de todas as famílias. A propriedade de bens materiais como engenhos, bois, canoas e, principalmente, pessoas escravizadas apresentaram-se como fatores de diferenciação e só ocorriam nas famílias remediadas e ricas, nas quais os filhos já estavam adultos e cujo número de bocas para alimentar não era maior do que o número de braços para trabalhar. Para Farias, nessa sociedade, a aquisição de escravos era um investimento que, para além do status, tinha utilidade nessa economia rural: a posse de dois ou três escravos não libertava um lavrador e sua família do trabalho de casa e da roça; no máximo, reduzia as horas de dedicação a esse trabalho e permitia que a família evitasse os serviços mais pesados. ${ }^{28} \mathrm{O}$ mais provável, e mais importante, é que desse à família maior grau de segurança, ao possibilitar aumentos da produção, tanto para o consumo doméstico como para a venda.

Os dados sobre a população escrava na Freguesia da Lagoa durante o século XIX apontam uma proporção média de $17 \%$ de escravos, tomando-se os anos de 1810, 1840, 1856, 1866 e 1872. Esse percentual acompanhava o perfil de utilização de mão de obra escrava relativamente comum em toda a região sul do país, inclusive nas demais freguesias que compunham a Ilha de Santa Catarina. ${ }^{29}$ A pesquisa nos inventários revelou

\footnotetext{
27 SCHWEITZER, 2006, p. 16.

28 FARIAS, 2003, p. 54.

29 CARDOSO, 2004, p. 41.
} 
que $60 \%$ dos falecidos possuíam entre 1 a 8 escravos, apontando um mundo de senhores donos de pequenos grupos de escravos pulverizados pelas propriedades.

Este é o perfil de posse escrava que podemos encontrar entre os proprietários da Freguesia da Lagoa da Conceição desde a sua fundação, na segunda metade do século XVIII, e ao longo do século XIX. Retomandose os registros de batismos, percebe-se a diminuição, a partir da década de 1840, do número de africanos novos batizados, o que indica que a população escrava da Freguesia da Lagoa estava em fase de crioulização.

\section{Arranjando a liberdade}

De volta a 1880, ano em que Roza e seu filho recebiam de sua proprietária a promessa escrita de se tornarem livres logo após a morte dela. Essa maneira de deixar de ser escravo foi o caminho trilhado pela maioria que obteve cartas de alforria na Freguesia da Lagoa, conhecido como "liberdade condicional", pois o escravo só se tornava livre depois que a condição imposta pelo senhor se cumprisse. Assim também aconteceu com os escravos Joaquim, Antônio, Amália, Eva, Fermino, Francisco, João, Amaro, Adão e Anna. Todos eles pertenciam ao casal Marcellino Cardozo Duarte e Maria Antônia da Silveira e receberam carta de alforria condicional no ano de 1879. A partir de então, viviam com a promessa de tornarem-se livres quando da morte de seus senhores.

Uma tipologia das cartas de alforria amplamente utilizada pelos pesquisadores classifica três categorias de formas de libertação: onerosa, condicional e gratuita. ${ }^{30} \mathrm{~A}$ alforria onerosa era aquela através da qual o escravo, mediante um pagamento em dinheiro, espécie ou até mesmo com outro escravo, comprava sua liberdade diretamente do seu senhor e podia, a partir daquele momento, como comumente se registrava, "gozar da sua inteira liberdade onde bem lhe convier". O senhor sempre recebia alguma forma de indenização ao conferir a liberdade ao escravo. Já a alforria condicional era aquela pela qual o senhor conferia liberdade ao escravo somente após o cumprimento de determinadas condições, bastante variadas, mas geralmente atreladas à prestação de serviços por

30 Ver os trabalhos de PENNA, 2005; CERVI, 2009; LIMA, 2007. 
determinado tempo. A alforria gratuita ou incondicional, por sua vez, era aquela pela qual o escravo obtinha a liberdade sem ônus ou condição mencionada pelo senhor, podendo gozá-la dali em diante "como se do ventre livre nascido fosse", outra expressão comum nesses registros. Contudo, tanto as liberdades passadas através das cartas de alforria classificadas como onerosas, assim como as condicionais e até mesmo as gratuitas não constituem cada uma dentro de seu conjunto maneiras exatamente iguais de libertação, pois podem diferir entre si as maneiras de pagar por uma liberdade, as cláusulas a que pode estar condicionada a manumissão e as razões, quando alegadas, de um senhor ao conferir uma liberdade gratuita. Estamos falando dos diferentes "arranjos de liberdade" - muitas vezes não apenas entre o senhor e o seu escravo.

Mais uma vez, temos o casal de proprietários Marcellino Cardoso Duarte e Maria Antônia da Silveira. Para o escravo pardo Miguel, de 34 anos, o arranjo de liberdade não envolvia prestar serviços apenas até a morte do casal: teria que servir por mais 7 anos ao filho destes, Manoel Cardoso Duarte. ${ }^{31}$ Já para o escravo africano Domingos, que recebeu carta de alforria de sua senhora Joaquina Rosa de Jesus em 1871, a liberdade viria após o cumprimento de mais três anos de serviços. ${ }^{32}$ Entre as cartas de alforria incondicionais, encontramos situações como as de João, Maria e seu filho Marcolino. Deixados como herança quando da morte de seus proprietários, no momento da partilha, foram libertados gratuitamente pelos herdeiros. ${ }^{33}$ Para os escravos Rachel, Luiza e Ignácia, a liberdade também viria gratuitamente, segundo a proprietária Francisca Carolina de Aguiar, em homenagem ao Clube Abolicionista e para expressar sentimentos de filantropia. ${ }^{34}$ Por fim, entre os arranjos de liberdade onerosa, encontramos na Lagoa escravos que contrataram com terceiros a prestação de serviços futuros como forma de pagar empréstimos para comprar suas alforrias diretamente de seus senhores. É o caso do pardo

31 CARTÓRIO DA LAGOA DA CONCEIÇÃO FLORIANÓPOLIS. Livro de Notas $n^{\circ}$ 5, folhas 1-1v. Registro de 27/02/1879.

32 CARTÓRIO DA LAGOA DA CONCEIÇÃO FLORIANÓPOLIS. Livro de Notas $n^{\circ}$ 3, folhas 8-8v. Registro de 13/04/1871.

33 CARTÓRIO DA LAGOA DA CONCEIÇÃO FLORIANÓPOLIS. Livro de Notas $n^{\circ}$ 1, folhas 23-23v. Registro de 21/04/1843; Livro de Notas $n^{\circ}$ 7, folhas 38. Registro de 16/06/1883.

34 CARTÓRIO DA LAGOA DA CONCEIÇÃO FLORIANÓPOLIS. Livro de Notas $n^{\underline{0}}$ 8, folhas 6-7v. Registro de 28/09/1884. 
Firmino, que em 1870, havia emprestado 500 mil réis de João da Costa Furtado para servir 10 anos a 50 mil réis por ano. Teria de trabalhar quatro meses do ano junto do credor, e nos oito meses restantes, poderia sair a trabalhar por conta própria, desde que pagasse 12 mil réis por cada mês. Podendo trabalhar para si, se conseguisse acumular dinheiro em seus serviços ou negócios, Firmino poderia pagar os 50 mil réis anuais e fazer o desconto dos anos que teria ainda de servir. ${ }^{35}$

\section{Fontes}

\section{CARTÓRIO DA LAGOA DA CONCEIÇÃO FLORIANÓPOLIS.}

Livro de Notas n-1 (1840-1856).

Livro de Notas $n^{0} 3$ (1870-1873).

Livro de Notas $n^{0} 5$ (1879-1880).

Livro de Notas $n^{\circ} 7$ (1882-1884).

Livro de Notas no 8 (1883-1886).

\section{Referências}

BARICKMAN, Bert J. Um contraponto baiano: açúcar, fumo, mandioca e escravidão no Recôncavo, 1780-1860. Rio de Janeiro: Civilização Brasileira, 2003.

BASTOS, Ana Carla. Os forros da Lagoa da Conceição: arranjos de liberdade numa freguesia rural da ilha de Santa Catarina (1840-1888). Monografia (graduação em História) - Universidade Federal de Santa Catarina, Florianópolis, 2008.

CABRAL, Oswaldo R. Nossa Senhora do Desterro. Notícia II. Florianópolis: Imprensa da UFSC, 1972.

CARDOSO, Paulino de Jesus Francisco. Negros em Desterro: experiências de populações de origem africana em Florianópolis, 1860/1888. Tese (doutorado em História) - Pontifícia Universidade Católica de São Paulo, São Paulo, 2004. CERVI, Pedro Germano. Alforria e momentos de instabilidade da autoridade senhorial na Ilha de Santa Catarina: 1829-1871. Trabalho de Conclusão de Curso (Graduação em História) - Universidade Federal de Santa Catarina, Florianópolis, 2009.

35 CARTÓRIO DA LAGOA DA CONCEIÇÃO FLORIANÓPOLIS. Livro de Notas $n^{\circ}$ 3, folhas 1e 2v-3. Registros de 04/01/1870 e 18/03/1870. 
COELHO, Manoel Joaquim de Almeida. Obra completa. Florianópolis: IHGSC, 2005.

FARIAS, Joice. "A Lagoa da Conceição também é dos pretos!": experiências dos grupos populares no leste da Ilha de Santa Catarina (1870-1920). Dissertação (mestrado em História) - Universidade Federal Fluminense, Rio de Janeiro, 2003.

HÜBENER, Laura M. O comércio da cidade de Desterro no século XIX. Florianópolis: UFSC, 1981.

LEANDRO, José Augusto. A roda, a prensa, o forno, o tacho: cultura material e farinha de mandioca no litoral do Paraná. Revista Brasileira de História. São Paulo, v. 27, n. 54, 2007. p. 261-278.

LIMA, Henrique Espada. Alforrias na Ilha de Santa Catarina, 1829-1888. In: ENCONTRO ESCRAVIDÃO E LIBERDADE NO BRASIL MERIDIONAL, 3., 2007, Anais... Florianópolis, 2007.

MAMIGONIAN, Beatriz G. Africanos em Santa Catarina: escravidão e identidade étnica (1750-1850). In: FRAGOSO, João Luis Ribeiro et al. (Org.). Nas rotas do Império: eixos mercantis, tráfico e relações sociais no mundo português. Vitória; Lisboa; Brasília: Ed. UFES; Instituto de Investigações Científicas Tropicais; CNPq, 2006, p. 609-644.

MOTTA, José Flávio. Corpos escravos, vontades livres: posse de cativos e família escrava em Bananal (1801-1829). São Paulo: FAPESP/Annablume, 1999.

PIAZZA, Walter F. Santa Catarina: sua história. Florianópolis: UFSC, 1983.

PENNA, Clemente Gentil. Escravidão, liberdade e os arranjos de trabalho na Ilha de Santa Catarina nas últimas décadas de escravidão (1850-1888).

Dissertação (Mestrado em História) - Universidade Federal de Santa Catarina, Florianópolis, 2005.

SCHWEITZER, Maria Helena Rosa. Africanos no sul do Brasil: rotas do tráfico e identidade étnica. Relatório de Pesquisa PIBIC/UFSC, 2006.

SILVA, Osvaldo Paulino. Arqueologia dos engenhos da Ilha de Santa Catarina. RS: Habilis, 2007.

VÁRZEA, Virgílio. Santa Catarina: a ilha. Florianópolis: Lunardelli, 1985.

ZIMMERMANN, Fernanda. O funcionamento da Armação baleeira da Lagoinha: hierarquia do trabalho e controle dos escravos na caça à baleia (Ilha de Santa Catarina, 1772-1825). Trabalho de Conclusão de Curso (Graduação em História) - Universidade Federal de Santa Catarina, Florianópolis, 2006. 


\section{|| Capítulo 4 ||}

\section{A Irmandade do Rosário e seus irmãos africanos, crioulos e pardos}

Claudia Mortari Malavota

Num dia de dezembro em 1844, o preto africano forro Francisco de Quadros, vestido com seu chapéu, calça de casimira azul, colete branco e sobrecasaca de pano percorre as ruas da pequena Vila do Desterro em direção à Igreja de Nossa Senhora do Rosário e São Benedito dos Homens Pretos, para participar de mais uma reunião da Irmandade homônima, da qual era irmão. O cenário que se descortina ao seu redor enquanto caminha é o de uma pequena vila cercada por morros, cortada por alguns riachos e fontes de água, apesar de Desterro ter sido oficialmente alçada a cidade em 1823. Acompanhando seus passos, desde a saída de sua casa na Rua da Palma, percorremos o bairro da Figueira, localizado nas imediações do porto, local de chegada de pessoas e de produtos. Talvez o nosso caminhante tenha observado o balançar das bandeirolas das canoas que vinham de outros portos da Ilha de Santa Catarina - como os do Contrato do Ribeirão, do Rio Tavares, da Lagoa, de Santo Antônio - e dos barcos e navios vindos do Rio de Janeiro, do Rio Grande do Sul, de Pernambuco, Montevidéu e Buenos Aires. Ou ouvido o burburinho das pessoas que comercializavam peixes nas canoas ao longo da praia central, o alarido de vozes de vendedores africanos e crioulos, escravos e libertos, nas barraquinhas que ficavam na praça, também, próximas à praia.

Em seu caminho, é possível que tenha passado em frente a alguma das tabernas existentes na vila, nas quais se vendia uma variedade de gêneros alimentícios, secos e molhados, como aguardente, açúcar, algodão, imbé, carne seca, cebolas, café, erva-mate, farinha de 
mandioca, feijão, fumo, figos passados, manteiga, passas, paios, peixeseco, queijos do Rio Grande e de Minas, sal, toucinho, vinho, vinagre e chá. Ou tivesse encontrado aqui e acolá algum conhecido que exercesse um ofício como os de sapateiro, alfaiate, barbeiro, ferreiro, marceneiro, serralheiro, tanoeiro, funileiro, entalhador ou pintor. Poderia também ter cruzado com Joaquina, sua escrava crioula, vendendo produtos no tabuleiro pelas ruas da vila; ou ainda, com suas afilhadas Ana, de nação Moçambique, e Maria da Costa, juntamente com tantos outros homens e mulheres, africanos, crioulos e pardos, escravos, libertos ou livres, bem como brancos pobres. Aliás, na vila do Desterro, as ruas, o porto e os espaços privados das casas eram os seus locais de trabalho e sobrevivência. Era comum, por exemplo, ver africanas e crioulas, circulando pelas ruas, vendendo seus quitutes em tabuleiros ou quitandas, outras tantas lavando roupas nos inúmeros córregos e fontes ou cozinhando e cuidando de suas crianças e as de seus donos. Homens africanos e crioulos carregavam mercadorias ou as vendiam pelas ruas da vila e cais do porto, trabalhando ao ganho ou de aluguel. Eram eles que embarcavam e desembarcavam os produtos dos navios e barcos para o abastecimento da vila. Alguns viviam envolvidos nas atividades marítimas, como armadores e mestres de embarcações. ${ }^{1}$

Esses homens e mulheres, ao realizar seus trabalhos e circular por todos os lugares, acabavam forjando inúmeras possibilidades de

1 Este artigo é parte da minha dissertação de mestrado Os Homens pretos do Desterro. Um estudo sobre a Irmandade de Nossa Senhora do Rosário (1841-1860). PUCRS, 2000. Anterior a este trabalho, o primeiro autor catarinense a fazer um estudo específico sobre a Irmandade do Rosário do Desterro foi CABRAL (1950). No ano de 2006, a partir do projeto de pesquisa financiado parcialmente pelo CNPq e sob a coordenação do prof. dr. Paulino de Jesus Francisco Cardoso, do NEAB/UDESC, intitulado Irmandades e Confrarias Católicas de Africanos e Afrodescendentes em Desterro no século XIX, outras pesquisas foram realizadas, resultando em trabalhos de conclusão de curso de graduação e de mestrado em História. Entre eles, destaco RASCKE (2009) e STAKONSKI (2009), e ainda, o trabalho de SILVA (2009), resultado de pesquisa desenvolvida junto ao Laboratório de História Social do Trabalho e da Cultura, coordenado pela profa. dra. Beatriz Gallotti Mamigonian.

Ao longo do texto, são utilizadas expressões como crioulo, preto, pardo, específicas do período histórico estudado e presentes nas fontes pesquisadas. Essas expressões eram categorias utilizadas para classificar os africanos e seus descendentes. Assim, crioulo referia-se ao descendente de africano já nascido no Brasil; preto, aos africanos de diversas regiões da África. Esses termos (preto e crioulo), juntamente com o pardo, também se referiam à cor e remetiam à condição social dos sujeitos: preto e crioulo para escravos ou forros (ex-escravo) e pardo, geralmente, para livres. 
sobrevivência e, ao mesmo tempo, estabelecendo relações conflituosas e de solidariedades. É nesse contexto que se inserem as igrejas católicas da Vila: a Igreja Matriz; a Capela do Menino Deus, anexa ao Hospital de Caridade; a Igreja de São Francisco e a de Nossa Senhora do Rosário. Além de constituírem espaços de devoção, possibilitavam, sobretudo, o estabelecimento de laços de amizade e solidariedade entre os confrades, através das chamadas irmandades religiosas. No caso dos africanos, pardos e crioulos, esse espaço era o da Irmandade de Nossa Senhora do Rosário, sediada na igreja de mesmo nome. Era para a Igreja do Rosário que se dirigia o preto forro Francisco, especialmente para tomar posse de seu cargo na mesa administrativa da irmandade. ${ }^{2}$

\section{Mas, afinal, o que é uma irmandade?}

As irmandades eram organizações que surgiram na Europa durante a Idade Média, em torno da devoção a um santo, agregando, em sua grande maioria, membros leigos. Seu objetivo era realizar atividades assistenciais aos pobres e doentes, sendo geralmente apoiados pela Igreja e pelos monarcas. No Brasil, a constituição de irmandades e Ordens Terceiras ocorreu com base na organização das Santas Casas de Misericórdia de Portugal, cujos deveres iam desde dar de comer a quem tem fome, de beber a quem tem sede, vestir os nus, visitar doentes e presos, dar abrigo aos viajantes, resgatar os cativos, até enterrar os mortos. Mesmo com esses deveres como princípios norteadores para organização, as irmandades no Brasil acabaram tendo suas características próprias, constituindo-se como associações corporativas que, através da devoção a um santo em particular, possibilitavam o estabelecimento de laços de solidariedade entre seus membros, os chamados irmãos, ao mesmo tempo em que lhes serviam como canal de ascensão social e representatividade. Dessa forma, era comum encontrar as irmandades dos poderosos, cujos membros faziam parte da "elite branca"; as dos "homens de cor", estas se

2 As informações acerca do africano forro Francisco de Quadros foram obtidas através da pesquisa no inventário deste, pertencente ao acervo do Arquivo Central do Tribunal de Justiça de Santa Catarina. Processo de Autos de Arrecadação dos Bens de Francisco de Quadros, 1854, Desterro, Capital da Província de Santa Catarina. Caixa Ano 1854. A trajetória de vida de Francisco foi discutida em minha tese de doutorado Os africanos de uma vila portuária no Sul do Brasil: criando vínculos parentais e reinventando identidades. PUCRS, 2007. 
dividindo tradicionalmente em crioulos, mulatos e africanos, ou ainda, as que agregavam indivíduos da mesma profissão. ${ }^{3}$

Em Nossa Senhora do Desterro existiram 11 irmandades, que se organizavam também segundo estes preceitos. Havia a da Ordem Terceira de São Francisco, criada a pedido da própria Câmara Municipal e instalada na Igreja Matriz do Desterro em 1745, constituída pelos "homens bons" da Vila, tendo como ministro (título usado pelo provedor) o próprio governador da época, o mestre de campo Pedro de Azambuja Ribeiro. Havia outras irmandades de "homens bons", como a do Senhor dos Passos, localizada junto da Capela do Menino Deus, fundada em 1765; a do Espírito Santo, de 1773; e a do Santíssimo Sacramento que, embora não se tenha a data exata de sua fundação, sabe-se que já existia em 1774. Do século XIX, a do Glorioso Arcanjo de São Miguel e Almas, criada em 1855, tinha como função enterrar os mortos e sufragar-lhes as almas. Nesse mesmo século, foram criadas a Irmandade de Nossa Senhora das Dores e a de São Sebastião, considerado o patrono contra o flagelo da peste. As irmandades de africanos, crioulos e pardos eram, respectivamente, a de Nossa Senhora do Rosário, existente desde 1726, mas fundada oficialmente em 1750, tendo sua capela inaugurada em 1780; a Irmandade de Nossa Senhora do Parto, que teve a sua própria capela em 1861; e a Irmandade de Nossa Senhora da Conceição, fundada em 1856 por um grupo de pardos livres. ${ }^{4}$

Os africanos e seus descendentes adotaram no Brasil outros santos de devoção, como São Benedito, Senhor do Bonfim, Santa Efigênia, São Sebastião e Santo Elesbão. O culto a Nossa Senhora do Rosário surgiu em 1282, quando São Domingos de Gusmão, seu devoto, fundou confrarias sob sua invocação em Portugal, França e Espanha. Depois de algum tempo abandonada, a devoção foi retomada dois séculos depois da morte do devoto, quando ocorria o processo de propagação da fé católica pelos dominicanos em terras da África. O culto chegou ao Brasil no século XVI, com os primeiros africanos escravizados. ${ }^{5}$ As igrejas do Rosário e de São Benedito estão, ainda hoje, espalhadas pelo Brasil, testemunhos dessa devoção de africanos e descendentes.

\footnotetext{
3 MESGRAVIS, 1976, p. 26-27; BOXER, 1969, p. 319-320; REIS, 1991, p. 553-555.

4 CABRAL, 1979, p. 413-448.

5 BASTIDE, 1971, p. 63; GRESELE, 1968, p. 4; VALENTE, 1994; BRAGA, 1987; RAMOS, 2000.
} 
Para que uma irmandade funcionasse, era preciso encontrar uma igreja que a acolhesse ou construir uma própria. Era comum que um mesmo templo acomodasse diferentes irmandades, que veneravam seus santos patronos em altares laterais. No entanto, na mesma igreja não funcionava mais de uma confraria com o mesmo nome, o que representa um aspecto fundamental de identidade. Além de ter um lugar para ficar, era imprescindível que a instituição tivesse seu compromisso, um estatuto que a regesse, aprovado pelas autoridades eclesiásticas e pelo Imperador no qual se estabeleciam as normas para a associação dos irmãos e das irmãs, a organização da mesa administrativa, com seus cargos e os critérios para o exercício de algumas funções, e, finalmente, as formas de assistência oferecidas aos sócios. É preciso considerar que a irmandade possuía como principal característica a solidariedade entre os irmãos, mas não estava isenta de conflitos e de uma estrutura hierárquica de poder.

\section{Como era organizada e quem eram os irmãos da Irmandade de Nossa Senhora do Rosário do Desterro?}

A Irmandade do Rosário teve dois compromissos ao longo do século XIX: o primeiro, de 1807; e o segundo, de 1842. Tudo indica que havia um compromisso anterior ao de 1807, aprovado por sua Majestade El Rei de Portugal, que foi perdido quando a Ilha de Santa Catarina foi invadida pelos espanhóis em 1777, no contexto da disputa de território entre Portugal e Espanha. A Ilha de Santa Catarina e, particularmente, a capital da província, Nossa Senhora do Desterro, foram desocupadas apenas em 1778, com a assinatura do Tratado de Santo Idelfonso e a delimitação dos territórios. ${ }^{6}$ Consta dos dois compromissos do século XIX que tanto homens quanto mulheres de diferentes condições sociais e origens étnicas poderiam fazer parte da irmandade, desde que pagassem a sua entrada e seus anuais. A administração da instituição ficava a cargo de uma mesa administrativa, composta por juízes, escrivão, tesoureiro, procurador e mesários, escolhidos através de eleição (ver quadro abaixo). Nestes cargos, as atas de eleição e os critérios estabelecidos em ambos os compromissos nos dão indícios acerca da presença, em sua grande

$6 \quad$ PIAZZA, 1983, p. 181-192. 
maioria, de sujeitos de origem africana, fossem escravos, livres ou forros. A presença de homens brancos era recorrente.

Quadro 4.1 - Cargos da Irmandade de Nossa Senhora do Rosário

\begin{tabular}{|l|l|}
\hline \multicolumn{1}{|c|}{ Compromisso de 1807 } & \multicolumn{1}{c|}{ Compromisso de 1842 } \\
\hline Rei & \\
\hline Rainha & \\
\hline Juíza de Vara & \\
\hline Juíza de Ramalhete & Juiz de Nossa Senhora do Rosário \\
\hline Juiz de Nossa Senhora do Rosário & Juiz de Nossa Senhora por Devoção \\
\hline Juiz de Nossa Senhora por Devoção & Juiz de São Benedito \\
\hline & Juiz de São Benedito por Devoção \\
\hline & Escrivão \\
\hline Escrivão & Tesoureiro \\
\hline Tesoureiro & Procurador da Irmandade \\
\hline Procurador & Procurador de Caridade \\
\hline & Juíza de Nossa Senhora \\
\hline & Juíza de Nossa Senhora por Devoção \\
\hline Juíza de Nossa Senhora por Devoção & Juíza de São Benedito \\
\hline & Juíza de São Benedito por Devoção \\
\hline & 18 Irmãos de Mesa \\
\hline 12 Irmãos de Mesa & 16 Zeladoras de Nossa Senhora e São \\
& Benedito \\
\hline & 8 Zeladoras de Órfãos \\
\hline & Regente \\
\hline & 6 Irmãos de Capelas \\
\hline & Reverendo Capelão \\
\hline Zelador \\
\hline Andador & Andador \\
\hline
\end{tabular}

O compromisso de 1807, por exemplo, indica que, como a instituição surgiu como resultado da ação e devoção de "Homens Pretos, e desde sua fundação o Juiz dela foi Homem daquela qualidade", é justo que o mesmo critério continue a ser utilizado para a escolha do juiz. Por sua vez, o cargo de tesoureiro deveria ser ocupado por "Homem branco, e sujeito de reconhecida capacidade, [...] mas debaixo da Administração e 
Ordem da Mesa". Várias evidências aqui são importantes. A primeira delas é a referência à presença de pretos no cargo de juiz da irmandade desde a sua fundação, e é preciso entender o sentido atribuído pelos irmãos ao termo preto. Relaciona-se a condição social, cor ou origem do sujeito? É importante considerar que, no século XIX, a noção de cor não designava um grupo racial ou níveis de mestiçagem, mas delimitava os lugares sociais. Dito de outra forma, etnia e condição jurídica eram indissociáveis. Nesta perspectiva, o termo pardo era atribuído aos libertos ou livres nascidos no Brasil. Preto designava escravo e forro de origem africana; e crioulos e mulatos eram termos atribuídos a escravos e forros nascidos no Brasil. Esses referenciais nos permitem perceber o sentido atribuído à cor: guardava relação com a condição social do indivíduo. Todos esses termos remetem à marca africana e, especificamente, o termo preto refere-se, na maioria das vezes, àqueles homens e mulheres trazidos do continente africano. Assim, ao especificar que o irmão deveria ser preto para ocupar o cargo de juiz, o compromisso referia-se a homens na condição de escravos ou forros, mas que fossem africanos, o que configurava a irmandade como instituição de homens que tinham em comum a origem (africana) e a marca da escravidão. A segunda evidência importante está relacionada à atribuição do termo homens, tanto para pretos quanto para os brancos, respectivamente, juiz e tesoureiro. Fossem escravos ou forros, africanos ou não, os irmãos pretos do Rosário se viam e se atribuíam a condição de homens e não coisas ou objetos alienáveis, destituídos de personalidade e vontade. Eram indivíduos que demonstravam ser capazes de reger sua instituição, tanto que, apesar de o tesoureiro ser branco, portanto um homem livre, sua autonomia era relativa, já que deveria exercer suas atribuições respeitando, acima de tudo, as decisões da mesa. Através da administração da irmandade, africanos e crioulos podiam transitar entre os brancos dirigentes, estabelecendo relações regulamentadas pelo compromisso da irmandade.

A instituição, organizada em consonância com os meios de socialização, reconhecidos e aceitos pela sociedade, era o meio de legitimar práticas de solidariedade entre os irmãos. A marca da escravidão foi uma característica marcante na Irmandade do Rosário, de forma que os cargos foram, ao longo do período, ocupados em sua maioria por escravos e forros e, portanto, por africanos e afrodescendentes. É necessário ressaltar que 
a entrada dos escravos na irmandade se fazia com o consentimento dos senhores; e eles fizeram bastante uso deste direito. É o caso, por exemplo, de Caetano, da casa de Manoel Teixeira; de Teresa, da casa de D. Ana; de Maria, da casa do tenente João Francisco de Amorim; de Domingos, do Sr. Manoel Antônio José Galdino; de José, escravo do Capitão Ludovino José Prates; de Joana, de Roque Roiz Prates; de Floriana, de Rita Genoveva e tantos outros. ${ }^{7}$ Especificamente, os cargos de rei e de rainha também evidenciam a presença majoritária de escravos na instituição: a maior parte dos eleitos para rei e rainha eram homens e mulheres escravos. A escolha desta nobreza ocorreu todos os anos, durante os 35 de vigência do compromisso de 1807, juntamente com a eleição dos outros membros da mesa, no dia da Festa de Nossa Senhora, 25 de dezembro. Festejavase a coroação dos reis, que eram acompanhados por um cortejo, com cantos e danças, num evento que se constituía um momento importante especialmente para os africanos, visto que muitos deles valorizavam formas políticas tradicionais centradas em monarcas, reinterpretando aspectos sociais e culturais de suas regiões da África. Os cargos de rei e rainha foram extintos com a aprovação de um novo compromisso, em 1842, que incorporou a Irmandade de São Benedito, com o título Compromisso de 1842 da Irmandade de Nossa Senhora do Rosário e São Benedito dos Homens Pretos. A mudança mais significativa ocorreu com relação ao cargo de juiz de Nossa Senhora. Se, anteriormente, para ser juiz era necessário que o irmão fosse preto e possuísse consideração e capacidade, pelo compromisso de 1842, os requisitos estabelecidos passaram a ser "zelo, possebilidade [sic], caráter e alguma representação civil”. O cargo deixou de ser exclusividade daqueles considerados pretos, ou seja, nascidos na África, e estabeleceu-se que o ocupante deveria possuir bens e ter representação civil. Com relação à posse de bens, não haveria impedimento de um escravo urbano exercer o cargo, já que, como trabalhadores de ganho na cidade, poderiam juntar algum dinheiro. $\mathrm{O}$ critério da "representação civil" é que mudava as coisas: com a exigência de que o juiz fosse cidadão, os escravos ficavam excluídos do cargo, e também

7 ARQUIVO DA IRMANDADE DE NOSSA SENHORA DO ROSÁRIO (AINSR). Livro de Atas, 18161861. Termos de Eleição. 
os africanos libertos. ${ }^{8}$ Entre 1842 e 1860 , ou seja, em 19 anos, apenas nove irmãos exerceram as atribuições de juiz, nenhum deles registrado como escravo. No entanto, é interessante constatar que a maioria continuou a ser africana, evidenciando que, apesar de não mais estabelecida em lei, a escolha de africanos para o cargo de juiz da irmandade continuou a ser corrente. Tal dado afirma a identidade da instituição como lugar dirigido por africanos, mas que representava também os seus descendentes.

E aqui, podemos voltar ao preto forro Francisco de Quadros, que se dirigia à Igreja do Rosário em dezembro de 1844: havia sido eleito e deveria assumir suas funções no cargo mais importante da irmandade, o de juiz. Ele era conhecido na velha Desterro como Francisco Pombeiro e por informações, sabia-se que era natural da África, nação benguela; ao longo da primeira metade do século XIX, criou uma rede de relações afetivas na vila: apadrinhou africanos recém-chegados, batizou filhos de africanos, criou sua própria família com uma mulher crioula, trabalhou na vila vendendo seus produtos e exerceu vários cargos na Irmandade do Rosário. É importante considerar que o termo nação benguela não se refere a uma origem étnica, mas à região da África Central Atlântica e, particularmente, ao porto de Benguela, lugar de embarque de africanos escravizados, sendo possível, portanto, sugerir que essa seja a região de procedência de Francisco. Por sua vez, é possível que o termo pombeiro se refira à profissão de vendedor ou quitandeiro, pois quando do seu falecimento, entre seus bens constavam, além de mesas, bancos e baús, três tabuleiros. ${ }^{9}$ Essas referências acerca de Francisco foram construídas a partir das vivências e do estabelecimento das relações sociais, marcando uma identidade que não é única, mas plural: preto forro, pombeiro, benguela. Em última instância, remetem a uma procedência africana, a uma experiência de escravidão e ao exercício de um trabalho. Demarcam uma condição jurídica, os lugares sociais e as hierarquias próprias da sociedade

8 Segundo Perdigão Malheiro, o escravo não possui personalidade civil, sendo dependente da vontade senhorial. MALHEIRO, 1976, p. 58. Sobre a questão do direito dos africanos, ver LARA, 2000.

9 O termo pombeiro, no contexto, poderia ser utilizado para se referir a um comerciante na África que se embrenhava pelo interior, trazendo informações aos traficantes ou que negociava pessoalmente os africanos escravizados; ou ainda à profissão de vendedor ambulante ou ao indivíduo que andava pelo interior do Brasil para buscar pistas de criminosos, trabalhando como informante da força pública. Sobre a escravidão na África, ver LOVEJOY, 2002; MEILLASSOUX, 1995. Acerca do significado do termo pombeiro, ver LOPES, 2003 e HOUAISS; VILLAR, 2001. 
do período. Como homem preto e africano, ocupou por três mandatos o cargo de juiz da Irmandade do Rosário, em 1844, 1848 e 1850. Além disso, foi irmão de mesa 12 vezes, uma vez procurador da irmandade e duas vezes procurador de caridade. ${ }^{10}$ Isso implica considerar que, de 1829 a 1850, esteve envolvido em todas as questões relativas à instituição, inclusive, numa disputa interna, ${ }^{11}$ ocasionada justamente pelo fato de o artigo que instituía o direito aos africanos de serem juízes da irmandade ter sido substituído no novo compromisso, como citado anteriormente.

Como o juiz de Nossa Senhora possuía primazia na mesa, e todos os integrantes deveriam agir sob sua ordem e autoridade, é possível que a indicação dos nomes para concorrerem à eleição influenciasse a escolha dos demais membros, de forma que recaísse sobre sujeitos que possuíam objetivos comuns. O escrivão, juntamente com o juiz do Rosário, um mesário mais antigo e o irmão procurador deveriam selecionar os nomes dos irmãos para a eleição. As relações pessoais e os objetivos comuns podem explicar por que alguns nomes se repetem. É o caso de Francisco de Quadros, que ocupou o cargo de juiz por três vezes, mas também do preto mina Luiz José Pereira Meirelles, que exerceu a função de juiz de Nossa Senhora e mesário; de Antônio José Gomes, que foi juiz do Rosário e também mesário; do preto mina Antônio da Costa Luz, juiz de Nossa Senhora, de São Benedito e mesário; do preto forro Benedito José Francisco Pereira, eleito juiz de Nossa Senhora, São Benedito e mesário, da mesma forma que o preto Guilherme Francisco de Campos; e de João Pequeno Lobo, eleito para juiz de São Benedito, Nossa Senhora e mesário - apenas para citar alguns que exerceram os cargos de juiz. Outro critério que, de certa forma, facilitava o estreitamento das relações entre os irmãos definia que ambos os juízes, do Rosário e de São Benedito, poderiam ser reeleitos sempre que os integrantes da mesa desejassem, e que depois de três mandatos seguidos, teriam lugar permanente nesta.

Para ocupar o cargo de escrivão, o irmão deveria demonstrar zelo, caráter, aptidões de escrituração e contabilidade. Nas atas de eleição, percebemos que um mesmo irmão exercia o cargo por muito tempo, o mesmo ocorrendo em relação aos cargos de tesoureiro e procurador da irmandade, sendo que estes, além de ter zelo, caráter, probidade, deveriam

\footnotetext{
10 AINSR. Livro de Atas de Eleição da Irmandade de Nossa Senhora do Rosário, 1816-1861.

11 Sobre as especificidades da briga e seus envolvidos, ver: MORTARI, 2000, cap. 3.
} 
possuir alguns bens materiais para responder pelas rendas da irmandade. O procurador era o responsável pelas causas judiciais. Além dos requisitos estabelecidos, era possível que um homem branco exercesse tais funções, pois era necessária a posse de bens materiais que respondessem pelas rendas da irmandade, bem como de alguns conhecimentos, como saber ler, escrever e fazer contabilidade. Escolher homens brancos para os cargos de tesoureiro e escrivão poderia ser uma decisão pragmática dos confrades, na medida em que o primeiro deveria ter recursos suficientes para cobrir as despesas da irmandade, caso fosse necessário, e o segundo precisava ser alfabetizado. Por outro lado, pode-se supor que tais cargos fossem objeto de negociação com os grupos dirigentes da cidade, elementos através dos quais os irmãos angariavam apoios fundamentais para a preservação da irmandade. A mesma questão pode estar ligada à existência do cargo de juiz por devoção, tanto de Nossa Senhora como de São Benedito, que não é especificado no compromisso de 1807 , assim como não o é no de 1842 . O cargo foi, durante os anos de 1842 a 1860, geralmente ocupado por homens ilustres da cidade, principalmente militares. Temos entre eles o coronel Joaquim de Almeida Coelho, juiz municipal; o capitão Manoel Francisco Pereira Netto; o capitão Domingos Luís do Livramento; o tenente Manoel Coelho; o tenente Antônio José Ruiz; o comendador Agostinho Leitão de Almeida; o reverendo cônego e vigário Antônio Joaquim Pereira. ${ }^{12}$ A presença desses homens permite apreender a importância da irmandade dentro do contexto local. Se por um lado isso pressupõe que deveria haver maior controle das ações dos africanos, crioulos e pardos, por outro, além de possibilitar maior arrecadação de fundos, ampliava o reconhecimento público desse território, que passava a ter um aspecto positivo frente à sociedade.

O cargo mais ocupado pelos escravos na irmandade a partir da implementação do compromisso de 1842 foi, sem dúvida, o de irmão de mesa, no total de 18 vezes. Por ele passaram Pedro, escravo de Luiz do Livramento; Antônio, escravo do major José Antônio da Luz; Samuel, de D. Feliciana Amália; Jacinto, do Sr. Emílio Goudim; e João, de D. Paula

12 É constante a presença de militares nos cargos na irmandade. A existência destes sujeitos se explica pelo caráter militar da ocupação da Ilha de Santa Catarina, e a posição estratégica desta como ponto de parada para os navios que se dirigiam ao Prata, na campanha de ocupação dessa região pela Coroa portuguesa. 
Tavares. Os irmãos, para exercer o cargo de mesário, já deveriam ter pelo menos três anos de participação na irmandade. Não eram apenas escravos que ocupavam esses cargos, mas também alguns de seus proprietários, como Amaro José Pereira, Antônio José Ruiz, Floriano José Vilela, Francisco Antônio César, Joaquim Ignácio da Silveira, José Luiz do Livramento, Luiz Nunes Pires.

Eram responsabilidade da mesa administrativa os assuntos referentes à irmandade, como a administração do patrimônio, o recolhimento dos aluguéis das casas, a aceitação de novos membros, o estabelecimento das despesas com festas e procissões, a manutenção da igreja e suas reformas, o recolhimento das anuidades, entre outros. Por isso, seus membros deveriam demonstrar zelo, prudência e capacidade, obedecendo sempre ao juiz no uso de suas atribuições, "tendo sempre em vista a Glória de Deus e o crescimento da Irmandade"13 na hora de votar qualquer assunto.

Outra instância que possivelmente permitia maior participação de irmãos escravos nas decisões da irmandade era a chamada mesa conjunta. Conforme determinava o compromisso, esta deveria compor-se dos irmãos eleitos e mais 12 sub-rogados, totalizando 36 votantes. Os critérios que estabeleciam a escolha dos sub-rogados eram já ter servido em mesa e ser homem prudente e de capacidade. Essa mesa deveria se reunir para decidir questões importantes para a irmandade, como alteração do compromisso; anulação de termo de mesa; venda, troca, doação ou compra de qualquer bem; problemas em relação aos membros ou empregados da irmandade; aceite de legados que implicassem em despesas para a instituição; requisição de favores especiais; inovações que não fossem do costume; ou decisão sobre questões não estabelecidas no compromisso.

As mulheres, embora não pudessem votar nas deliberações da mesa, exerciam alguns cargos, como o de zeladora e juíza de Nossa Senhora e de São Benedito. Sua presença é um dado importante para caracterizar as irmandades pretas e pardas, representando um contraste em relação às dos brancos, nas quais a presença masculina parece ter sido predominante. A atribuição das zeladoras se relacionava com a limpeza da igreja, o cuidado dos órfãos e, principalmente, com a participação em todas as solenidades 13 AINSR. Compromisso da Irmandade de Nossa Senhora do Rosário e São Benedito dos Homens Pretos,
1842. 
para dar Glória a Deus e edificar os fiéis com seus exemplos. As juízas, por sua vez, deveriam demonstrar zelo e piedade cristã, dando bom exemplo e fomentando a adesão à devoção na instituição. Além disso, deveriam promover, através de persuasões, as entradas de novas irmãs e fazer com que as zeladoras de Nossa Senhora e de São Benedito cuidassem da limpeza e decência do templo. O cargo de juíza de São Benedito foi o que contou com uma presença maior de escravas, enquanto apenas uma exerceu o de juíza de Nossa Senhora do Rosário. É provável que os cargos ocupados pelas juízas fossem exercidos por mulheres livres pobres ou forras. Observamos que, embora não constasse no compromisso, havia a escolha da juíza por devoção de Nossa Senhora e de São Benedito, cargo ocupado, ao que parece, por senhoras ilustres, como D. Luíza, esposa do irmão Alexandre Jacques; a Sra. D. Maria Nunes; a ilustríssima Sra. D. Maria de Freitas Noronha; a ilustríssima Sra. Felizarda Amália Brocado, entre outras. As especificações Dona e Senhora eram indicativo de status social; possivelmente, essas senhoras tinham certo reconhecimento na sociedade.

Portanto, a irmandade era composta, em sua grande maioria, por homens e mulheres africanos, crioulos e pardos de diferentes condições sociais: escravos, forros e livres, que estavam distribuídos pelos diversos cargos da instituição. Outros cargos, ocupados por pessoas ilustres, poderiam ser espaços concedidos como estratégia para angariar prestígio à instituição e fortalecê-la. A Irmandade do Rosário, lugar constituído por múltiplos e diferentes sujeitos, ao longo do século XIX, possibilitou uma série de práticas de ajuda e solidariedade entre os irmãos.

\section{Qual a função social da irmandade?}

As irmandades, seus devotos, conflitos, alianças e significados a elas atribuídos foram objeto de estudo de inúmeras pesquisas, cujas abordagens pontuam sua significação como um espaço de solidariedade, construção e reforço das identidades. Especificamente, as irmandades compostas em sua maioria por africanos e crioulos foram utilizadas para o estabelecimento laços de solidariedade e de ajuda mútua. Evidentemente, a Irmandade do Rosário era uma organização institucional, que expressava toda a ambiguidade da ordem escravista: a exploração colonial, a expansão 
da fé e as hierarquias sociais. Sua principal razão de ser era o culto católico e a devoção a Nossa Senhora do Rosário, mas enquanto lugar próprio, inserido no contexto da cidade, a instituição vai permitir que seus irmãos elaborem diferentes estratégias de solidariedade, com destaque para o enterro e o sufrágio da alma do irmão falecido, a educação dos órfãos e a compra da alforria dos escravos.

É importante considerar que os irmãos, apesar da origem africana, inseridos em outro contexto, reelaboraram suas culturas. Dito de outra forma, não é mais possível ir a um passado africano para legitimar as práticas dos irmãos africanos e seus descendentes da irmandade. É preciso considerar que a cultura tem o poder de se inscrever e se renovar em contextos de adversidade. Viver numa sociedade escravocrata, sob um sistema normativo que tendia a restringir e a regular ao máximo a mobilidade desses sujeitos, procurando reduzi-los à impossível condição de coisas, e sob a hegemonia da religião e das práticas religiosas cristãs condicionou essas transformações na bagagem cultural que trouxeram. Este aspecto pode ser evidenciado em relação a uma das principais preocupações da irmandade: preparar um funeral decente para seus irmãos e familiares. Tal preocupação está ligada tanto à tradição cristã quanto à africana.

$\mathrm{Na}$ primeira, o objetivo era a salvação da alma e, portanto, ter uma "boa morte" implicava que a alma não ficasse presa ao inferno ou ao purgatório, mas passasse para a vida eterna, junto aos santos e Deus. A tradição africana, por sua vez, atribuía maior importância ao culto dos mortos, pois implicava a elaboração do ancestral, e por isso, diante da morte, a sociedade se organizava para que o homem continuasse a existir no país dos ancestrais, pois de lá poderia interceder pelos vivos. Como afirma Fábio Leite ${ }^{14}$, nas sociedades africanas, a morte está ligada a questões referentes à própria formação do homem, constituindo-se como um valor civilizatório de extrema importância. Para o africano, o homem possui diferentes fases em sua vida, e a morte é encarada como a última configuração do homem. Vendo-se diante da morte, a sociedade se organiza para que o homem continue a existir no país dos ancestrais. Aí reside a importância fundamental da cerimônia funerária, ocasião que permite à sociedade realizar esta mudança crucial do ser

14 LEITE, 1982. 
humano. Portanto, além dos aspectos culturais herdados da influência católica, percebem-se também traços da cultura africana, já que existia a preocupação em conduzir a alma do morto para o país dos ancestrais após o seu enterro, propondo assim a sua imortalidade, para que ficasse perfeitamente estabelecida enquanto estado diferente do ser, que o liga a um grupo social determinado. É a elaboração do ancestral.

Essa estratégia de solidariedade entre os irmãos da Irmandade do Rosário se constitui como maneira concreta de auxílio mútuo em um contexto histórico que tende a percebê-los sempre como os outros, cuja marca comum é a escravidão. Portanto, a preocupação dos membros da irmandade com o enterro e o sufrágio permite vislumbrar uma pluralidade de usos e apropriações da origem comum e do contexto que vivenciavam. $O$ compromisso de 1807 já estabelecia os critérios de assistência aos irmãos, ou seja, o enterro e o sufrágio do irmão falecido, assim como de sua mulher e filho menor de 12 anos. Caso o irmão caísse em estado de pobreza e tivesse ocupado cargos na irmandade, seria assistido por esta através de esmolas, e de missas, depois de morto. Em vários itens dos artigos, aparece a referência a um costume já praticado: o número de missas que deveriam ser rezadas para o irmão falecido, o acompanhamento de seu corpo ou o empréstimo do esquife da irmandade. Os mesmos critérios de assistência e ajuda aos irmãos no enterro e sufrágio das almas permanece entre as determinações do compromisso de 1842. Uma das preocupações era um lugar decente para o enterro, fator importante para a segurança dos mortos e dos vivos, pois um enterro adequado garantiria a intercessão do morto junto aos deuses pelos vivos. Caso contrário, se o morto não fosse enterrado adequadamente, ele poderia ter uma existência penosa, atrapalhando, então, o mundo dos vivos.

Cabia ao tesoureiro da irmandade cuidar do enterro dos irmãos falecidos, de suas mulheres e de seus filhos, incluindo os pobres que não podiam pagar as anuidades. Assim, a irmandade cuidou para que seus membros tivessem enterros decentes, fossem eles ricos ou pobres, comprometendo-se ainda a acompanhar solenemente os parentes. Sempre que falecesse qualquer irmão, os sinos da igreja seriam tocados, e mesmo que o morto fosse sepultado em outra igreja, os sinos também tocariam. Nos enterros, cabia aos capelistas e ao regente conduzir o corpo do irmão falecido. Porém, se este tivesse servido em algum cargo 
ou fosse reconhecido benfeitor da irmandade, seu corpo seria conduzido por oficiais. O enterro deveria ser seguido com tochas acesas, conforme o costume, conduzidas por capelistas. Era um direito da irmandade acompanhar o enterro dos irmãos falecidos e havia um ritual de preparação do corpo para o funeral. Em Desterro, depois de lavado e vestido, era costume carregar-se o corpo de casa para a igreja e desta, ao cemitério, em caixão aberto ou não, fazendo uma volta pela cidade. Era preciso o reconhecimento público.

A morte no Brasil oitocentista era motivo de festa. Não era o silêncio que acompanhava os ritos fúnebres, mas o barulho, visto como facilitador da comunicação entre o homem e o sobrenatural. Por isso, nos funerais e nas manifestações públicas, as cerimônias eram marcadas por sons de tambores, cantos e danças, atitudes e comportamentos que expressavam o estreitamento dos laços comunitários, para vencer a morte pela elaboração do ancestral. Havia a preocupação com o sepultamento. Assim, de acordo com o compromisso, a pessoa que estivesse em perigo de morte e quisesse entrar na irmandade seria admitida a partir do pagamento de determinada quantia. No entanto, nos jazigos da irmandade só poderiam ser enterrados os irmãos. Caso houvesse pagamento, a exceção seria aberta, mas não poderia ser uma sepultura perpétua. Caso o irmão não viesse para a igreja em enterro solene, a irmandade iria esperá-lo à porta, de luz alçada, para conduzi-lo à urna e depois à sepultura.

$\mathrm{Na}$ Europa, a partir do século XVIII, registrou-se uma mudança com relação aos ritos funerários, que passaram a ser mais simples, possivelmente por causa das idéias iluministas do período. É nesse contexto que se propaga a doutrina dos miasmas existente desde a Antiguidade, segundo a qual as matérias orgânicas em decomposição, sob a influência da temperatura, da umidade e dos ventos formavam vapores prejudiciais à saúde, infectando o ar que se respirava. A partir daí, tem-se a transferência dos cemitérios para fora das cidades. Entretanto, esse ritmo de mudança na Europa variou de região para região, e o povo resistiu à simplificação do funeral. Todavia, a suntuosidade dos funerais não significava mais o julgamento de Deus, mas o da sociedade sobre os seus membros ou a importância econômica e social do morto. Em todo Brasil, até o início do século XIX, os enterros ocorriam no interior das igrejas ou em cemitérios contíguos a estas. Só depois é que surgiram os 
cemitérios desvinculados das igrejas. ${ }^{15}$ Em Desterro, o cemitério público foi criado em 1840, nas imediações da cidade, no caminho do Estreito (onde hoje se localiza a cabeceira da ponte Hercílio Luz) e entregue à administração da Câmara Municipal. No terreno, as irmandades do Santíssimo Sacramento, do Rosário, do Espírito Santo e a Ordem Terceira receberam suas áreas demarcadas. No entanto, levou algum tempo ainda para que os irmãos passassem a ser ali sepultados. Em 1844, o juiz e demais mesários da Irmandade do Rosário entraram com um pedido à Câmara Municipal requerendo o terreno que lhes era atribuído, para cercá-lo e iniciar ali as inumações dos irmãos; no mesmo ano, em outubro, novo pedido foi feito. No cemitério público, foram sepultados nos jazigos da irmandade, no ano de 1855, por exemplo, a preta Catharina, de 30 anos mais ou menos, natural da Costa da África e escrava de Joaquim Fernandes Capella; o pardo João Thomé, de 50 anos, casado e natural da cidade de Desterro; a crioula Ernestina, de 17 meses, filha de Francisco Antônio César, membro da irmandade, casado e com filhos naturais, de Desterro; e a crioula liberta Efigênia, de 60 anos, natural de Desterro, em 5 de maio de $1855 .{ }^{16}$

Não era apenas com a sepultura que a Irmandade se preocupava, mas também em realizar um número determinado de missas para o morto. Daí a preocupação expressa no compromisso, de que, assim que acabasse o sepultamento, os irmãos se retirassem à sacristia para largar as tochas e depois se dirigissem à igreja, onde rezariam a estação de costume, junto com o reverendo capelão. Caberia à irmandade mandar rezar dez missas de esmola extraordinária, e depois, dependendo do cargo ocupado pelo irmão falecido na instituição, mais um número de missas: se o irmão houvesse servido de capela, doze; de mesa, quinze, como também para as zeladoras; para os oficiais, vinte; para a juíza de Nossa Senhora e o juiz de São Benedito, trinta, o mesmo se estendendo aos juízes jubilados. Mas não era apenas no dia do enterro que se rezava pelos irmãos. Ainda nas atribuições do reverendo capelão, percebemos a preocupação em invocar

15 REIS, 1991, p. 73-86.

16 AHMF. Registro de Correspondência, Ofícios da Câmara Municipal. 1843-1845. AH no 94 (128 BC). Ofício à Presidência, 03 de Julho de 1844; Ofício ao Presidente da Província, 10 de Outubro de 1844; Livro de Registro de Óbitos; novembro de 1854 a março de 1858, no 5. Registros № 3906, 3881, 4070, 3991. 
a memória dos mortos, pois cabia a ele celebrar missas pelos irmãos e benfeitores vivos e defuntos, nas segundas, nos sábados, domingos e dias santos de todo o ano.

E aqui, voltamos a Francisco de Quadros. Em 29 de junho de 1852, ele já se encontrava doente, tanto que solicitou aos irmãos da mesa da Irmandade do Rosário a sua exoneração do cargo de juiz, que ora ocupava. ${ }^{17} \mathrm{Um}$ ano depois, seus bens eram arrecadados pelas autoridades competentes da cidade; quem informou seu falecimento e cuidou do enterro foi outro africano, Feliciano dos Passos, também irmão da instituição. Quatro anos depois da sua morte, seus irmãos de confraria ainda mandavam rezar missas em sua memória e pela sua alma. Aliás, não só por ele, mas também por Agostinho Pires, Antônio José Gomes e Francisco das Chagas, todos africanos. ${ }^{18}$

Cabia à irmandade, além de enterrar e sufragar as almas de irmãos falecidos, cuidar da educação dos órfãos, que deveriam frequentar a escola para aprender a ler, escrever e cantar. Às zeladoras cabia o cuidado com o alinho e o asseio dos meninos, que ficavam sob a responsabilidade do irmão procurador de caridade. Este deveria "saber das escolas em que aprendem, falar aos professores e muito rogar-lhes o esmero do seu adiantamento" ${ }^{19}$ Cabia aos órfãos assistir às festas de Nossa Senhora do Rosário e de São Benedito, juntamente com o procurador de caridade.

Em 1859, numa reunião de mesa extraordinária na irmandade, o procurador expôs a impossibilidade de se fazer cumprir algumas das disposições do compromisso na sua íntegra. Entre elas, a que se referia à educação dos meninos. Na busca de alternativas para que se pudesse realizar a educação destes filhos dos irmãos pobres, foi proposta a criação de uma escola na igreja, na qual se ensinasse a ler, escrever e contar. Estas obrigações com os órfãos revelam os laços de solidariedade estabelecidos entre os irmãos. Ao que tudo indica, a irmandade se constituía como uma grande família, e a partir dela, africanos e crioulos tentavam viver, num contexto escravista, da melhor maneira possível.

\footnotetext{
17 AINSR. Ata de Reunião da Irmandade de Nossa Senhora do Rosário, 1852, p. 150-151.

18 AINSR. Livro Caixa da Irmandade de Nossa Senhora do Rosário, 1856.

19 AINSR. Compromisso da Irmandade de Nossa Senhora do Rosário e São Benedito dos Homens Pretos do Desterro, 1842.
} 
Também cabia à irmandade promover a liberdade dos irmãos cativos, sempre que possível. Para isso, havia na igreja uma grande caixa chapeada por dentro e por fora, com três chaves: a "caixa para libertar os irmãos cativos", ${ }^{20}$ na qual os fiéis colocavam suas esmolas, para benefício daqueles. A cada mês, a caixa era aberta, o dinheiro contado e levado para o cofre. O sorteio do nome do irmão a ser beneficiado com o dinheiro arrecadado acontecia no dia da festa de Nossa Senhora, quando um menino com o braço nu tirava o nome de dentro da urna. Não encontramos dados que nos indiquem quantos irmãos cativos foram libertados. O que importa é que a irmandade transformou-se em ponto de referência para a busca dessa liberdade por parte de africanos e crioulos. Mesmo quando a irmandade passou por dificuldades econômicas, os irmãos empreenderam mudanças no compromisso para que a prática continuasse. Em 1859, o procurador propôs a formação de um pecúlio dos irmãos de condição escrava, para ser usado exclusivamente na compra da sua alforria. A irmandade, ao garantir a formação de um pecúlio com o qual os escravos poderiam comprar sua liberdade, estava intervindo na relação entre senhores e escravos. Afinal, em tese, toda propriedade pertencia ao senhor, e a formação do pecúlio fora do seu controle atentava contra o domínio senhorial.

A Irmandade do Rosário, na primeira metade do século XIX, procurou estabelecer ações de ajuda aos seus irmãos, em sua maioria, africanos e crioulos, escravos ou forros: enterrando e rezando pela alma do falecido, educando os filhos órfãos e comprando a alforria dos escravos. Agindo dessa forma - mesmo como instituição elaborada e organizada a partir de um modelo europeu de associação e devoção, baseado na cultura hegemônica da Igreja Católica -, acabou se constituindo em lugar estratégico na busca de autonomia por parte destes sujeitos de origem africana e com a marca da escravidão. Pode-se considerar que, embora a existência de tal instituição dependesse da aprovação das autoridades locais e senhoriais para funcionar e possuísse uma hierarquia - a exemplo da mesa administrativa, que exigia certos critérios para a participação -, na irmandade, os irmãos agiam de acordo com os interesses do grupo.

Francisco de Quadros se constitui um excelente exemplo deste universo do século XIX: forro, comerciante, africano, casado com uma

20 Ibidem. 
102 crioula, dono de escravos, padrinho de africanos e crioulos e membro da irmandade. Através de suas relações envolvendo a instituição e seus vínculos familiares, pode-se supor certa honorabilidade constitutiva da sua identidade. ${ }^{21}$ Um dicionário da época assim define honra: "tem honra o homem que, constantemente, e por um sentimento habitual, procura alcançar a estima, boa opinião, e louvor dos outros homens, e trabalha pelo merecer". ${ }^{22} \mathrm{O}$ sentido aqui empregado aponta para práticas e condutas reconhecidas socialmente. Evidentemente, o sentido de honra para esse africano poderia ser bem diferente daquele entendido pela sociedade da época, mas poderia também ser composto por esse, o que implica compreender a complexidade inerente às formas de sobrevivência das populações de origem africana no contexto. Além disso, segundo Sheila Faria, é preciso considerar que, no contexto histórico referido, um indivíduo bem situado, com prestígio social e honra, não possuía necessariamente fortuna. As referências à honra são outras. "Dentro do que se estabelecia como status social de um indivíduo, inseriam-se normas de conduta e de representação social que, muitas vezes, não refletiam a situação econômica dos envolvidos. Pobreza e prestígio podiam, muitas vezes, andar juntos". ${ }^{23}$

A trajetória de Francisco representa as múltiplas formas de vivência e criação de vínculos afetivos e de sociabilidade. Permite, inclusive, compreender o que a Irmandade do Rosário representou para os irmãos africanos, crioulos ou pardos, tanto escravos quanto libertos ou livres, que dela participavam.

\section{Fontes}

ARQUIVO DA IRMANDADE DE NOSSA SENHORA DO ROSÁRIO

Compromisso da Irmandade de Nossa Senhora do Rosário, 1807.

Livro de Atas, 1816-1861.

Livro Caixa da Irmandade de Nossa Senhora do Rosário, 1830-1847.

\footnotetext{
21 A questão sobre a honra e seus significados e práticas também foi apontado por PAIVA, 2001.

22 SILVA, 1831, p. 123.

23 FARIA, 1995, p. 82.
} 
Compromisso da Irmandade de Nossa Senhora do Rosário e São Benedito dos Homens Pretos, 1842.

ARQUIVO CENTRAL DO TRIBUNAL DE JUSTIÇA DE SANTA CATARINA

Processo de Autos de Arrecadação dos Bens de Francisco de Quadros, 1854, Desterro, Capital da Província de Santa Catarina. Caixa/Ano 1854.

\section{Referências}

BASTIDE, Roger. As religiões africanas no Brasil. Primeiro Volume. São Paulo: Editora da USP/Livraria Pioneira Editora, 1971.

BOXER, C. R. O Império Colonial Português. Lisboa: Edições 70, 1969.

BRAGA, Julio Santana. Sociedade Protetora dos desvalidos: uma irmandade de Cor. Salvador: Ianamá, 1987.

CABRAL, Osvaldo R. Notícia histórica da Irmandade de Nossa Senhora do Rosário. Florianópolis, 1950.

. História de Santa Catarina. 3. ed. Florianópolis: Lunardelli. 1977. . Nossa Senhora do Desterro. Notícia I. Florianópolis: Lunardelli, 1979.

CERTEAU, Michel. A invenção do cotidiano. 1. Artes de fazer. 3. ed. Rio de Janeiro: Vozes, 1994.

CUNHA, Manoela Carneiro da. Negros, estrangeiros: os escravos libertos e sua volta à África. São Paulo: Brasiliense, 1985.

FARIA, Sheila Siqueira de Castro. Fortuna e família em Bananal no século XIX. In: CASTRO, Hebe Maria Mattos de; SCHNOOR, Eduardo (Org.). Resgate: uma janela para o oitocentos. Rio de Janeiro: Topbooks, 1995.

GEERTZ, Clifford. A Interpretação das Culturas. Rio de Janeiro: Editora LTC, 1989.

GINZBURG, Carlo. Mitos, emblemas e sinais. São Paulo: Companhia das Letras, 1989.

GRESELE, Ottilia. A Irmandade dos Negros de Porto Alegre. In: Estudos leopoldinenses. São Leopoldo: Faculdade de Filosofia, Ciências e Letras de São Leopoldo. no 6, 1968.

HOUAISS, Antônio; VILLAR, Mauro de Salles. Dicionário Houaiss da Língua Portuguesa. Rio de Janeiro: Objetiva, 2001.

LARA, Silvia Hunold. Legislação sobre escravos africanos na América Portuguesa. Madrid: Fundación Histórica Tavera, 2000. 
LEITE, Fábio Rubens da Rocha. A questão ancestral: notas sobre ancestrais e instituições ancestrais em sociedades africanas Ioruba, Agni e Senufo. Tese (Doutorado em Sociologia) - Universidade de São Paulo, São Paulo, 1982.

LOPES, Nei. Novo dicionário bantu. 2. ed. Rio de Janeiro: Pallas, 2003.

LOVEJOY, Paul E. A escravidão na África. Uma história de suas transformações. Rio de Janeiro: Civilização Brasileira, 2002.

MAFFESOLI, Michel. A transfiguração do político: A tribalização do mundo. Porto Alegre: Editora Sulina, 1997.

MALAVOTA, Claudia Mortari. Os africanos de uma Vila Portuária no Sul do Brasil: criando vínculos parentais e reinventando identidades. Tese (Doutorado em Sociologia) - Pontifícia Universidade Católica do Rrio Grande do Sul, Porto Alegre, 2007.

MALHEIRO, Perdigão. A escravidão no brasil: ensaio histórico, jurídico, social. Brasília: Vozes/INL, 1976.

MEILLASSOUX, Claude. Antropologia da escravidão: o centro de ferro e o dinheiro. Rio de janeiro: Jorge Zahar, 1995.

MESGRAVIS, Laima. A Santa Casa de Misericórdia de São Paulo (1599-1884): Contribuição ao Estudo da Assistência Social no Brasil. São Paulo: Conselho Estadual de Cultura, 1976.

MORTARI, Claudia. Os Homens pretos do Desterro: um estudo sobre a Irmandade de Nossa Senhora do Rosário (1841-1860). Dissertação (Mestrado em História) - Pontifícia Universidade Católica do Rio Grande do Sul, 2000.

PAIVA, Eduardo França. Escravidão e universo cultural na colônia: Minas Gerais, 1716-1789. Belo Horizonte: Editora da UFMG, 2001.

PEDRO, Joana Maria. Mulheres honestas e mulheres faladas: uma questão de classe. Florianópolis: UFSC, 1994.

PIAZZA, Walter F. Santa Catarina, sua história. Florianópolis: Lunardelli: Editora da UFSC, 1983.

QUINTÃO, Antônia Aparecida. A Irmandade de Pretos e Pardos em Pernambuco e no Rio de Janeiro na época de D. José I: um estudo comparativo. In: SILVA, Maria Beatriz Nizza. Brasil, colonização e escravidão. Rio de Janeiro: Nova Fronteira, 2000.

RAMOS, Donald. A influência e a cultura popular em Minas Gerais: um comentário sobre a interpretação da escravidão. In: SILVA, Maria Beatriz Nizza. Brasil, Colonização e Escravidão. Rio de Janeiro: Nova Fronteira, 2000.

RASCKE, Karla. Resolveo a Mesa que pelo menos houvesse huma missa resada: festas, procissões e celebração da morte na Irmandade de Nossa Senhora do 
Rosário e São Benedito dos Homens Pretos em Desterro/SC, 1860 a 1890. Monografia de Conclusão de Curso em História. UDESC, Florianópolis, 2009. REIS, João José. A morte é uma festa: ritos fúnebres e revolta popular no Brasil no século XIX. São Paulo: Companhia das Letras. 1991.

SILVA, Antonio Moraes. Diccionario da Lingua Portuguesa. Lisboa: Impressão Régia, 1831.

SILVA, Jaime José. Sons que ecoavam no passado: as festas de origem africana em Desterro na primeira metade do século XIX. Monografia (Conclusão de Curso em História). Universidade Federal de Santa Catarina, Florianópolis, 2009.

STAKONSKI, Michelle Maria. Da sacristia ao consistório: tensões da Romanização no caso da Irmandade de Nossa Senhora do Rosário e São Benedito dos Homens Pretos, Desterro/Florianópolis (1880-1910). Monografia (Conclusão de Curso em História) - Universidade do Estado de Santa Catarina, Florianópolis, 2009.

THOMPSON, E. P. Costumes em comum: estudos sobre a cultura popular tradicional. São Paulo: Companhia das Letras, 1988.

VALENTE, Ana Lúcia E. F. O negro e a igreja católica: o espaço concedido, um espaço reivindicado. Campo Grande, MS: CECITEC/UFMS, 1994. 


\section{|| Capítulo 5 ||}

\section{Entre a diversão e as proibições: as festas de escravos e libertos na Itha de Santa Catarina}

Jaime José dos Santos Silva

As irmandades de "homens pretos" - como eram chamadas as irmandades dos escravos e libertos - representaram socialmente os diversos grupos de pessoas cativas e alforriadas, fossem africanas ou nascidas aqui, durante o período da escravidão no Brasil. Esses indivíduos encontravam nas irmandades espaços para reconstruir suas identidades sociais e religiosas. Buscavam dignidade e respeito, sendo suas vidas marcadas por estigmas em torno da cor e da condição social. Irmandades, como associações leigas em torno de santos de devoção, existiam em todo o império português, de Goa e Macau, no oriente, até Cuiabá, no extremo oeste. Mas um traço marcante também disseminado pelo império era a escolha de Nossa Senhora do Rosário, São Benedito e Santa Ifigênia pelos africanos e seus descendentes. ${ }^{1}$

O principal evento promovido pelas irmandades de "homens pretos" era certamente a festa de coroação de rei (e, em geral, também rainha), comumente celebrada na época do Natal. As festas eram feitas em homenagem aos santos de devoção. As posições de rei e rainha representavam prestígio e liderança dentro da instituição, e as pessoas coroadas no dia da festa geralmente eram respeitadas dentro da irmandade. A coroação era acompanhada, com muito barulho, pelas ruas das cidades e se tornava elemento central de devoção, um momento em que escravos e libertos recriavam, através das danças e representações, aspectos de

1 VIANNA, 2007, p. 85-86. 
suas histórias e elaboravam rituais que reafirmavam características de sua comunidade. Para os africanos e seus descendentes, a festa era um momento de afirmar que eram portadores de cultura e histórias próprias; para os senhores e autoridades coloniais, trazia a segurança de que escravos e libertos estavam praticando o cristianismo, ainda que, muitas vezes, com danças e instrumentos característicos de culturas de origem africana. $^{2}$

Festejos desse tipo ocorreram, desde pelo menos o século XVII, em todas as regiões onde a presença africana e o emprego da mão de obra escrava na América portuguesa eram significativos. Em muitos lugares, ocorrem até hoje. Foram principalmente essas irmandades que introduziram no Brasil o que João José Reis e outros autores chamam de "catolicismo barroco". De cunho popular, esse catolicismo se caracterizava por manifestações religiosas grandiosas e rituais de muita pompa, cerimônias caracterizadas por músicas com instrumentos próprios, teatralização e danças, cujas características eram a velocidade dos passos e a independência dos membros superiores e inferiores. ${ }^{3}$

Já os batuques foram manifestações registradas no Brasil desde o século XVI, segundo José Ramos Tinhorão, e também envolviam danças, tambores e trajes de festa. Mais afastados da tradição católica, frequentemente estavam associados a práticas religiosas de origem africana. Como os observadores eram, em geral, estranhos ao universo dos celebrantes, quando não eram parte da repressão, seus relatos são muitas vezes imprecisos e preconceituosos.

Imaginar que em Desterro não houve danças, batuques e festejos dos africanos e crioulos seria ignorar manifestações integradas às suas vidas cotidianas, às suas crenças e que, muitas vezes, davam sentido às suas existências. É preciso tirar do silêncio os tambores de suas celebrações e devolver sons à história da população escrava e liberta na Ilha de Santa Catarina. Apesar de existirem poucos registros sobre o tema, ainda assim é possível perceber que a vida da população de origem africana na Ilha ia além das atividades associadas à exploração de seu trabalho. A presença desses homens e mulheres na sociedade foi acompanhada de momentos marcados pelos batuques e pela celebração de seus santos de devoção,

2 SOUZA, 1999, p. 258-259.

3 Ver: SOUZA, 2002, p. 180-181. 
com atos e representações característicos de culturas de origem africana, nos quais esses elementos africanos se fundiam com os de outras culturas e instituições do Novo Mundo.

Para adentrar o universo das festas dos escravos e libertos de Desterro na primeira metade do século XIX, utilizei neste trabalho relatos de viajantes estrangeiros de duas expedições, que deixaram suas impressões sobre as festas dos escravos e libertos: a primeira aportou em Desterro em 1803, e a segunda, em 1815. Utilizei também a legislação de nível local, que reflete a preocupação das autoridades com as festas e reuniões de escravos e libertos. Os indícios presentes nessas fontes, mesmo fragmentados no tempo, permitiram esboçar interpretações a respeito das manifestações festivas na Ilha de Santa Catarina, principalmente na cidade de Desterro.

A primeira metade do século XIX trouxe mudanças para as festas em diversas regiões do Brasil. Tais mudanças atingiram tanto aquelas ligadas às irmandades, de brancos e de pretos, quanto as que se faziam fora dela, mais informais, como os batuques. Em Desterro, antes da independência do Brasil, as festas pareciam acontecer com o consentimento e até o apoio das autoridades e os senhores de escravos. Na década de 1840, a proibição e a perseguição das festas de coroação de reis e dos batuques já estavam bem estabelecidas. Sempre que se aproximavam as comemorações de final de ano, as autoridades ficavam em alerta.

\section{Tambores e festejos: a diversão nas ruas de Desterro}

A partir do começo do século XIX, mas especialmente depois da abertura dos portos, muitas expedições estrangeiras estiveram no Brasil. Seus integrantes, naturalistas, militares, cartógrafos, artistas, se preocupavam em publicar relatos para o público europeu, ávido por descrições das Américas. Nesses relatos, os aspectos peculiares da natureza e das populações que habitavam o território eram privilegiados; as festas e os cortejos pelas ruas das cidades, representados por uma série de atos, rituais e danças, ganharam destaque. Por meio das narrativas daqueles que passaram por Desterro no início do século XIX, é possível perceber aspectos e significados que esses viajantes extraíram das celebrações que testemunharam nas ruas durante o período marcado pelas festas de 
Natal. Era o momento em que africanos e crioulos, a maior parte deles escravizada, aproveitavam as comemorações das festas católicas para celebrar seus próprios ritos. Naqueles dias, o trabalho diário era deixado de lado, e o sentido da liberdade, mesmo que temporário, se transformava em emoção, dança e música marcadas por representações características. Essas manifestações foram destacadas por uma visão interessada no exotismo dos ritmos, dos instrumentos musicais, dos passos e das vestimentas.

A primeira expedição estrangeira a aportar em Desterro no século $\mathrm{XIX}^{4}$ foi russa e ancorou no porto em 23 de dezembro de 1803, com dois navios: o Nadeshda (Esperança) - comandado pelo capitão Adam Johann von Krusenstern - e o Neva - comandado pelo capitão Urey Lisiansky. Nos navios, estavam também os naturalistas Georg Heinrich von Langsdorff e Wilhelm Gottlieb von Tilesius. O tempo que permaneceram na Ilha de Santa Catarina permitiu que deixassem uma descrição riquíssima sobre a natureza e a população de Desterro, inclusive relatos muito vivos das festas de final de ano dos cativos. O naturalista Tilesius produziu talvez o único registro iconográfico de uma festa de coroação de reis negros em Desterro no século XIX.

Figura 5.1 - Uma festa negra na Ilha de Santa Catarina (1803). W. G. von Tilesius

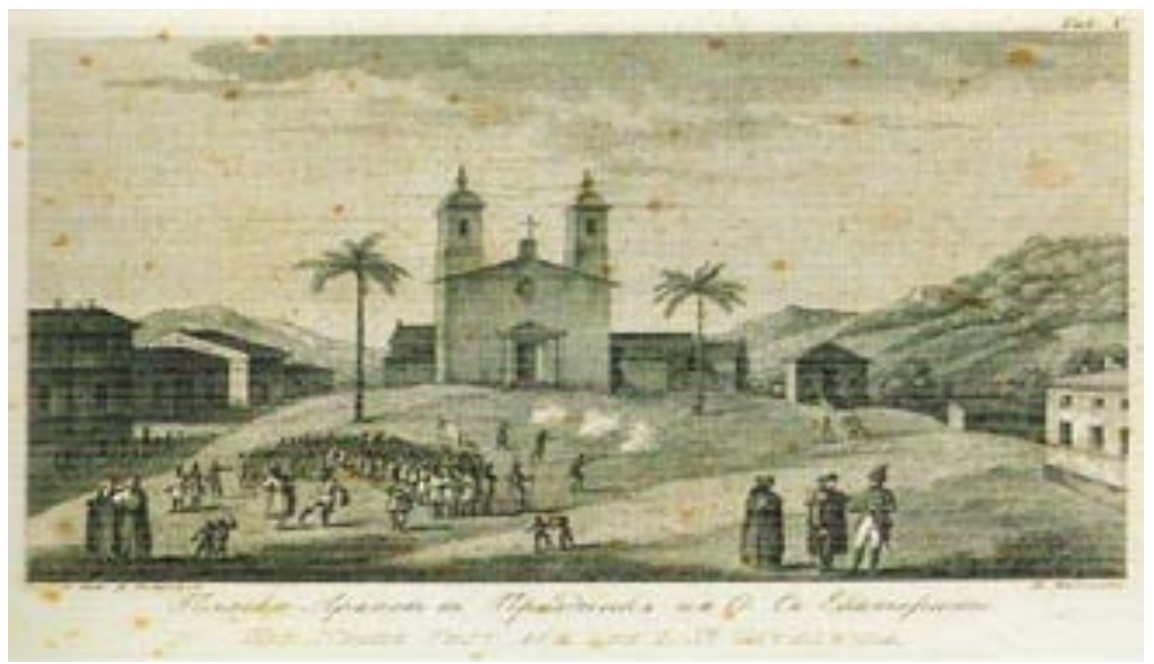

Fonte: CORRÊA, 2005, p. 125.

4 Todos os relatos foram retirados da obra HARO, 1996. 
A imagem representa uma festa realizada no Largo da Matriz de Nossa Senhora do Desterro por africanos e pessoas de ascendência africana. Um cortejo é aberto por um homem e uma mulher de mãos dadas; ao lado, um homem os acompanha com um violão. Logo atrás, mais alguns músicos e, ao lado deles, um homem empunha um bastão, como um cetro. No meio do cortejo há um objeto que sugere um estandarte. Crianças rodeiam a cena, como se estivessem brincando. No canto direito, em primeiro plano, Tilesius escolheu representar pessoas da sociedade local, talvez autoridades, que acompanhavam a festa de forma distanciada. Atrás do cortejo, três homens executam uma salva de tiros. Esse elemento demonstra que os soldados e as autoridades estavam ali para presenciar as celebrações e a salva de tiros; sugere que o momento da festa contava com o apoio da "ordem estabelecida". É uma representação simplificada, talvez mesmo estilizada, da festa, que demonstra grande preocupação com a composição da imagem. A festa ao vivo era certamente mais ruidosa e contava com mais público.

Areprodução do naturalista Tilesius se aproxima muito da constatação sobre os aspectos das festas da Irmandade de Nossa Senhora do Rosário feita por Claudia Mortari para o período posterior, 1830 a 1841. Segundo a historiadora, as festas da irmandade "foram frequentemente alegres, barulhentas, com cantos, danças e procissões". ${ }^{5}$ Em sua pesquisa referente à Irmandade de Nossa Senhora do Rosário, a historiadora constatou a presença de pagamentos de velas, ceras, foguetes, bombas, músicos e também a arrecadação de esmolas para a realização das festas. Um ato solene contava com a presença de autoridade, tais como o reverendo arcipreste vigário da Vara e o reverendo cônego vigário da Matriz. ${ }^{6}$ Esses elementos são muitos parecidos com os que foram reproduzidos por Tilesius, porém, a imagem nos traz um dado a mais: um casal no centro do cortejo. Este, juntamente com a data do registro da expedição russa - período do Natal - e o enredo da iconografia - cortejo, com dança e música - constituem indícios que nos permitem interpretar como o rei e a rainha festejando a coroação durante a festa de devoção a Nossa Senhora do Rosário.

A Irmandade de Nossa Senhora do Rosário da vila de Desterro foi fundada em 1750. Sua primeira capela foi construída em 1780. A Igreja

\footnotetext{
MALAVOTA, 2002, p. 59-60.

6 Ibidem.
} 
que conhecemos data de 1830. O Compromisso de 1807 da Irmandade de Nossa Senhora do Rosário foi uma reelaboração, uma vez que o original havia sido destruído pelos espanhóis, durante a invasão da Ilha de Santa Catarina em 1777. ${ }^{7}$ O compromisso de 1807 continha 16 artigos, entre os quais, o quarto e o décimo terceiro merecem destaque, pois tratam da eleição anual de um rei e uma rainha e também definem o dia da festa da irmandade. O quarto artigo especificava: "Haverá um Irmão que seja eleito pela Mesa para Rei e uma Irmã para Rainha [...]". ${ }^{8} \mathrm{O}$ décimo terceiro estipulava a realização da eleição dos novos irmãos e da festa de Nossa Senhora do Rosário, no dia 25 de dezembro: "Segundo o costume antigo desta Irmandade, no dia vinte e cinco de Dezembro, se fará Mesa para a futura nova Eleição [...] e se fará a festa da Nossa Senhora do Rosário, com Missa cantada, e sermão, com a maior grandeza [...]" . ${ }^{9}$ A menção ao "costume antigo" ajuda a explicar que a representação de Tilesius é mesmo de uma festa de coroação de reis da Irmandade do Rosário.

Outros membros da expedição de 1803 também deixaram suas impressões sobre as festas de Natal em Desterro. A manifestação festiva dos escravos despertou a admiração do capitão Lisiansky, muito mais do que a festa promovida pelos senhores, pois, segundo o viajante, as festas dos senhores se diferenciavam pouco das promovidas pelos católicos da Europa:

[...] o que não acontecia em relação aos negros que, estando divididos em grupos, de acordo com seus aspectos, produziam em mim grande diversão, com suas esquisitas danças típicas, onde eram introduzidas ações e gestos característicos, à maneira de suas condutas em batalhas. Este inocente entretenimento de danças continuava por uma quinzena, sem interrupções. Não sabia de que mais me admirar: se dos seus espíritos infatigáveis ou de seus procedimentos recatados. Este festival reflete, eu penso, uma grande distinção de humanidade dos senhores; e estes em troca de favores também era evidente na sobriedade e decoro dos escravos; qualidade rara a ser encontrada nesta raça, em outras colônias. O último dia de festa foi encerrado com uma espécie de comédia,

7 Ibidem, p. 34-35.

8 COMERLATO; MORTARI, 2000, p. 5. Ver também CABRAL, 1950.

9 Ibidem. 
interpretada diante do governador; um dos intérpretes agradeceu ao governador em nome de seus compatriotas, pelas alegrias que eles tinham gozado sob a sua administração, durante o ano precedente. $^{10}$

Apesar da perspectiva típica dos viajantes da época, atraídos pelo exótico, existem algumas considerações que merecem destaque: a "divisão em grupos" sugere a presença de diferentes nações africanas, demonstrando a diversidade da população africana na Ilha e presente no dia da festa; Lisiansky também ressalta a presença da dança, da teatralização dos gestos, simulando uma batalha e o apoio e a assistência das autoridades locais, que assim como no desenho de Tilesius, estavam presentes.

Os elementos descritos no relato coincidem com um importante aspecto da sequência que, de maneira geral, envolvia os rituais de coroação de reis discutidos por Marina de Mello e Souza. Seria o momento após a coroação, quando o cortejo seguia pelas ruas com suas danças, representando as embaixadas do Congo e reinos distantes, quase sempre envolvendo guerras - batalhas - interpretadas com grande energia. ${ }^{11}$ Tudo indica também que o viajante fundiu na descrição vários dias da festa, sem deixar muitos detalhes, o que dificulta maior interpretação de tudo o que foi representado ao longo dos quinze dias de celebração.

Outro ponto a ser levantado no relato do capitão do Neva é o fato de ele considerar a permissão da festa como sinal da benevolência dos senhores. Por trás da "distinção de humanidade" dos senhores, o ato de conceder ou proibir a festa era, na verdade, uma questão de negociação e interesses. Muitas vezes, autorizar a festa facilitava a manutenção e o controle da ordem, não era uma decisão espontânea ou um ato de caridade dos senhores e da autoridade, mas resultado da pressão escrava que reivindicava o direito à diversão. Para muitos senhores e autoridades, era também uma forma de adaptação da população africana à sociedade escravista.

A julgar pelos registros dos viajantes, os escravos e libertos de Desterro sabiam aproveitar muito bem esse consentimento para a

\footnotetext{
10 HARO, 1996, p. 154-155.

11 SOUZA, 1999, p. 254.
} 
diversão. Em um relato riquíssimo, o naturalista Langsdorff descreveu com interesse e estranhamento uma enérgica dança acompanhada pelos sons dos tambores, durante uma festa no dia 31 de dezembro de 1803:

Geralmente, os escravos negros se movimentam com muito ruído e barulho pelas ruas, mas este ano choveu tanto, que eles foram obrigados a festejar seus bacanais em míseras choupanas ou nas bodegas públicas. Encontrei com facilidade o terreiro de danças no centro da vila, pois o som da música e os gritos dos dançantes ecoavam à distância; digo música, mesmo que não se ouvisse um só dos nossos instrumentos europeus de som ou de corda. Era uma gritaria monótona, uma marcação barulhenta e selvagem do compasso, com as batidas dos chocalhos e palmas indicando à distância o lugar da reunião. [...] O rei ou o mestre do grupo dançante se destacava de todos os outros companheiros do baile pela estatura, as dimensões do corpo e os gestos. Como herói, ele conduzia seu povo, que se reunia em círculo em torno dele. Ao invés do elmo azulado, sua cabeça estava coberta de brilho, papel dourado e penas coloridas, e em vez do plastrão, usava pequenas franjas de lantejoulas ao peito; sóis e estrelas recortadas em papel dourado e prateado adornavam todo o ambiente. Na mão esquerda, este herói segurava um bastão de dois pés de comprimento, que era atritado em outro menor na mão direita. Em lugar de músicos, havia um círculo de negros sentados ao chão em um canto e batiam com as mãos sobre uma pele de boi esticada sobre um toco de árvore - este era o tambor. A maioria dos presentes ao baile estava vestida com uma tanga à cintura ou calças curtas, quase sem roupas, enfeitados com inúmeras penas coloridas, fitas e seda e um diadema de papel dourado. Alguns cobriam o rosto com máscaras, outros estavam horrivelmente lambuzados de vermelho, branco e outras cores. Negros e negras, como foi dito, circundavam seu chefe e, conforme as habilidades, dançavam no centro do círculo, fazendo movimentos dos mais estranhos e peculiares; outros cantavam, ou melhor, emitiam alguns gritos africanos que eram incompreensíveis. Eles gingavam de uma maneira incomparável os quadris, girando-os horizontalmente em forma de círculo, enquanto que a parte superior do corpo permanecia quase que imóvel, equilibrando-se nas pernas que se movimentavam velozmente; assim, também sacudiam os músculos do pescoço, dos ombros, das costas, de uma maneira tão indescritível, que pareciam dominar cada um destes músculos. A maior destreza foi apresentada 
por uma negra seminua, que movimentava concomitantemente os quadris com gestos artísticos e ligeiríssimos dos pés. A deformação dos músculos do rosto, assoprando as bochechas e outros gestos horríveis faziam parte da dança. [...] O objeto principal de tais danças consiste na representação de atos comuns da vida, por exemplo, da pesca, caça, guerra, etc. ${ }^{12}$

Comecemos por destacar do relato que a festa normalmente acontecia nas ruas da cidade, mas por causa de chuva, tinha sido transferida para locais cobertos. Nessa festa, ao contrário da ilustração de Tilesius, parecia não haver instrumentos europeus, pois Langsdorff relatou ouvir música produzida por instrumentos diferentes dos que conhecia. Havia somente instrumentos africanos, chocalhos e tambores.

O viajante descreve a presença de um "rei ou o mestre", assim como suas características e vestimentas. Apesar de mencionar a presença de um rei, a descrição parece estar mais próxima das práticas do batuque. O termo batuque no século XIX se referia a uma dança de caráter geral: os negros, em círculos, executavam cantos, passos e sapateados, acompanhados por um ritmo marcado com palmas e instrumentos de percussão. No meio do círculo, um dançarino ou uma dançarina, às vezes os dois, se destacavam do grupo mostrando grande agilidade e requebro do corpo em movimentos individuais. ${ }^{13}$

Em 1643, no Recife, o viajante Zacharias Wegener fez uma descrição, retomada por José Ramos Tinhorão, que nos traz elementos muito próximos dos que foram descritos sobre Desterro. ${ }^{14} \mathrm{Na}$ descrição do Recife, a cena envolvia músicos sentados num tronco de árvore e tocando tambores; outro homem, ao centro, raspava um longo reco-reco em forma de bastão; ao redor dos músicos, um grupo de negros dançava fazendo roda em torno de uma mulata. $O$ instrumento era o mesmo da descrição de Langsdorff; segundo Tinhorão, no século XIX, era chamado de macumba. A descrição identifica um momento do ritual de terreiro da religião africana, o que nos leva a pensar que talvez também estivesse sendo representada em Desterro.

\footnotetext{
12 HARO, 1996, p. 169-170.

13 RAMOS apud ABREU, 1994, p. 189.

14 TINHORÃO, 1988, p. 29.
} 
Não foram apenas os integrantes da expedição de 1803 que relataram as festas dos escravos e libertos pelas ruas de Desterro. Veremos agora as narrativas de outra expedição russa, comandada por Otto von Kotzebue, que ali aportou em dezembro de 1815. O naturalista Adalbert Von Chamisso ficou na Ilha de Santa Catarina até o final do mês. Sobre as festas de fim de ano, ele apenas comentou que

o Natal como em toda a parte, e aqui também, era a festa das crianças e dos negros. Eles se movimentavam por toda a localidade aos grupos, fantasticamente adornados, indo de casa em casa cantando, brincando, dançando, em troca de insignificantes presentes, entregando-se à mais descontraída alegria. Era a época de Natal, dentro deste mundo de verdes palmeiras e laranjas! ${ }^{15}$

O relato de Chamisso, apesar de pouco descritivo, traz informações que nos permitem perceber o movimento dos negros pelas ruas de Desterro no dia da festa. Esses "insignificantes presentes", apesar de minimizados, sugerem o pedido de esmolas feito pelas pessoas que saíam em cortejos; pode-se imaginar que a festa estava ligada à igreja, pois as esmolas serviam de importante fonte de arrecadação de fundos para a irmandade.

No mesmo período da passagem de Chamisso (1815), esteve na Ilha o desenhista russo Louis Choris, que deixou um relato rico em detalhes, apesar da visão comum de estranhamento:

Os negros africanos não trabalham aos domingos. Durante as festas de fim de ano, gozam de uma liberdade quase ilimitada. Eles se reúnem em grupos de dez a vinte; seus senhores os vestem de seda com ornamentos bizarros que consistem em plumas, fitas e pequenos espelhos. Cada grupo tem um chefe que está armado com uma espada; outros têm címbalos, flautas e tambores, pedaços de bambus talhados em cortes transversais. [...] Estes grupos vão de casa em casa dançando; e quanto mais se aproxima o fim destes três dias, mais eles se extravasam em arrebatamento nos seus prazeres [...]. Os negros amam a dança, iniciando este divertimento pela tarde. Um negro e uma negra dançam sozinhos, muitas vezes ao som de um instrumento chamado "Carimba" pelos portugueses,

15 HARO, 1996, p. 235. 
e "Bansa" pelos negros. [...] O homem que toca este instrumento serve-se de acompanhamento um canto que faz correr lágrimas dos olhos dos negros, de maneira que se vêem os negros dançando e chorando ao mesmo tempo. ${ }^{16}$

Graças ao relato de Choris, temos mais elementos dos festejos de fim de ano dos africanos da Ilha de Santa Catarina. A descrição de grupos de pessoas ricamente ornadas, com instrumentos musicais, cada um com "um chefe armado com uma espada", passando de casa em casa, sugere uma celebração religiosa com coleta de esmolas para os santos de devoção. $\mathrm{O}$ artista russo também indicou que a festa tinha momentos diferentes: ao fim dos três dias, as danças se intensificam. Em 1815, foram coroados pela Irmandade de Nossa Senhora do Rosário, segundo consta da Ata da Mesa Diretora da Irmandade, o rei Antônio e a rainha Felipa. Quem sabe não eram Antônio e Felipa que, segundo Choris, dançavam ao som do "bansa", acompanhados "por um canto que faz[ia] correr lágrimas dos olhos dos negros"?

Os relatos de 1803 e 1815 não especificam claramente se havia o rei e a rainha, nem se foram coroados. Mas a data de realização das festas - período do Natal - e alguns rituais dramáticos indicam uma possível festa de coroações de reis negros, principalmente na representação feita por Tilesius, em 1803. As descrições feitas por Lisiansky, no mesmo ano, e Choris, em 1815, também sugerem a presença dessa prática. Porém, seus relatos abrangem vários dias de festa, o que leva a crer que outras manifestações mais próximas dos rituais africanos também eram realizadas; algo que, na descrição do naturalista Langsdorff, fica evidente. Nesse sentido, devemos considerar que, além das práticas de eleições de reis negros, com cortejo, danças e músicas em homenagem aos santos de devoção - celebração mais próxima dos preceitos cristãos e aceita pelas autoridades coloniais e representantes da Igreja -, havia também batuques que não estavam ligados à irmandade e que encontravam no momento das comemorações de final de ano um espaço para se manifestar.

\section{A proibição das festas em nome da moral e do sossego públi- co: consentimentos e intolerâncias}

16 Ibidem, p. 243. 
Durante as primeiras décadas do século XIX, as festas pareciam acontecer sem que houvesse qualquer oposição, inclusive contando com a participação - como expectadores - das autoridades locais. Uma situação bem diferente daquelas descritas pelos viajantes começou a ser vista conforme a cidade de Desterro foi se desenvolvendo, e novas políticas de controle do espaço público e da mobilidade dos escravos e libertos foram implantadas, visando a quebra de antigas práticas do regime colonial. Essas atitudes seguiam uma tendência nacional no XIX, reflexo da chegada da Coroa Portuguesa ao Rio de Janeiro, em 1808, e principalmente do processo de construção do Estado depois da Independência do Brasil, após 1822. Práticas antes toleradas por certos setores da sociedade colonial brasileira começaram a ser associadas a costumes bárbaros, contrários à civilização que se queria implantar. Em momentos de maior insegurança e tensão social, as manifestações culturais dos escravos e libertos eram vistas como como oportunidades para organização de revoltas, algo que fazia aumentar ainda mais a situação de cerco aos escravos. Principalmente depois das tentativas de rebeliões ocorridas na Bahia - que culminaram no levante dos Malês, em 1835 - os homens de mando, marcados pelo medo de revolta em outras regiões do país, se preocuparam em criar leis que intensificassem o cerceamento às práticas culturais de origem africana.

O que se observou em todas as cidades do Império brasileiro foi um progressivo esforço dos governos locais, para estabelecer leis, decretos, normas de postura municipais e editais de polícia, com o objetivo de proibir não só as celebrações, mas controlar ao máximo todos os espaços públicos utilizados pela população livre, liberta e escrava, principalmente nos centros urbanos.

Em Desterro, a posição das autoridades se alinhava com o ideal de civilização que se tentava impor nas principais cidades do Império, principalmente após 1835. Por meio das leis implantadas nesse período, podemos perceber toda a tensão e a preocupação com o controle da população cativa e liberta, principalmente de africanos, pelas ruas da capital. Através da Lei de 1ำ de outubro de 1828, iniciou-se a implantação de normas que permearam o cotidiano da cidade e que tiveram impacto direto sobre as festas descritas pelos viajantes no início do século XIX. A lei reformulou as funções e atribuições das Câmaras Municipais das 
Províncias, determinando em seu artigo 66, parágrafo 12: “Poderão autorizar espetáculos públicos nas Ruas, Praças e Arraiaes, huma vez que não offendão a moral publica [...]". ${ }^{17}$ Sendo assim, além das festas, qualquer ajuntamento de escravos ou libertos podia ser considerado uma ameaça à "moral pública" por não condizer com os padrões que os governantes do recém-formado país queriam implantar. No dia 24 de abril de 1835, foi aprovado pela Assembleia Legislativa Provincial de Santa Catarina o decreto número 10, deixando clara a preocupação das autoridades frente à movimentação dos escravos e libertos, principalmente os africanos, pelos espaços urbanos da cidade: “Art. 1o - Fica prohibido, depois do anoitecer, todo o ajuntamento nas Praças, Ruas e Estradas de quatro ou mais escravos, ou libertos Africanos, sós ou promiscuamente. Os que assim forem encontrados serão presos e punidos [...]". ${ }^{18}$ Interessante perceber que esse decreto provincial foi aprovado três meses depois do levante dos Malês; dois meses mais tarde, seria aprovada a lei imperial determinando a pena de morte para os escravos que atentassem contra a vida dos seus senhor, seus familiares e feitores.

Além de leis e decretos imperiais e provinciais, as posturas municipais também regulavam o comportamento dos escravos e libertos e serviam como instrumento de controle social por parte das autoridades locais. O Código de Posturas da Câmara Municipal da cidade de Desterro era específico no Artigo 38, de 1845, sobre a proibição dos batuques realizados por escravos crioulos e africanos e também libertos, fazendo menção aos reinados africanos das irmandades. Eram visadas agora as mesmas manifestações descritas pelos viajantes estrangeiros no início do século XIX, então sem quaisquer proibições para as suas realizações. O artigo especificava: "Ficão prohibidos d'aqui em adiante, os ajuntamentos de escravos, ou libertos para formarem batuques; bem como os que tiverem por objectos os supostos reinados africanos, que por festas costumão fazer". ${ }^{19}$ As posturas tinham um objetivo disciplinador, objetivando controlar e reprimir a circulação da população cativa e liberta, bem como

17 ARQUIVO HISTÓRICO MUNICIPAL DE FLORIANÓPOLIS (AHMF). Registros de Leis Imperiais para Câmara Municipal. 1828-1829. no 54. Cx: 10. fl.18.

18 ARQUIVO HISTÓRICO DA ASSEMBLEIA LEGISLATIVA DE SANTA CATARINA (AHAL/SC). Ofícios - 1835-1848. Escravos. Decreto no 10 determinando o que os escravos não podiam fazer em 24/04/1835. Doc. 03, p. 13-14.

19 AHAL/SC. Desterro, Código de Posturas. Lei no 222 de 10 de maio de 1845. 
coibir algumas práticas sociais africanas e crioulas nos espaços públicos, dificultando a associação destes grupos de indivíduos. Veremos adiante que este artigo era evocado pelas autoridades de Desterro quando o final do ano se aproximava.

$\mathrm{Na}$ primeira metade do século XIX, a tentativa de imprimir uma "civilização moderna nos trópicos" ${ }^{20}$ muitas vezes esbarrou em limites e ambiguidades de um período em que os valores herdados do período colonial ainda existiam. Nesse sentido, havia permissões e recuos pessoais que contornavam as proibições oficiais e faziam com que algumas festas fossem autorizadas e continuassem a ser realizadas, porém, com menor frequência e intensidade.

Apesar de não possuirmos fontes iconográficas ou relatos que descrevam as festas pelas ruas da cidade de Desterro após a Independência do Brasil, através de documentos dos integrantes da Câmara Municipal e dos Oficiais de Polícia, é possível perceber a preocupação e a tentativa de proibir esses "folguedos" em Desterro e no interior da Ilha de Santa Catarina. Isto abre caminho para argumentar que essas práticas resistiram durante algum tempo na cidade. Mesmo se tratando de documentos oficiais, é possível perceber que por trás das falas dos homens de mando, a vontade de festejar por parte dos escravos e seus descendentes, sempre que se aproximava o final do ano.

Em dezembro de 1842, num oficio ao juiz de paz Joaquim Luiz da Rosa, da Freguesia da Lagoa, a Câmara Municipal relatava ter recebido um ofício "versando sobre os supostos reinados africanos que nesse distrito pretendem pôr em execução os Pretos Cativos [...]" e pedia para que o juiz cumprisse com o dever que lhe impunham as leis:

Tendo levado ao conhecimento da Câmara Municipal desta Cidade o seu offício de 13 do corrente versando sobre os suppostos reinados africanos que nesse districto pretendem pôr em execução os Pretos Captivos, sendo tal procedimento em contrario as Posturas, e mais Leis. Resolveo a mesma Camara que V.Sa. cumpra pela sua parte com que depoem o Art. 66 - 12 da Lei do $1^{\circ}$ de Outubro de 1828, como determina o Art. 2o do Regulamento Policial no 120. Deus guarde a Vsa. Desterro 15 de Dezembro de $1842\left[\ldots . .{ }^{21}\right.$

20 ABREU, 1999 apud SOUZA, 2002, p. 316-318.

21 AHMF. Registro da Correspondência da Câmara Municipal de Desterro, 1840/1843. NA no 85 (143 
O documento sugere que os escravos africanos na Freguesia da Lagoa da Conceição também coroavam seus reis. Por trás da preocupação da Câmara, podemos perceber que os escravos africanos estavam dispostos a se organizar para a realização de suas festas de final de ano. Tal aviso parece não ter sido atendido pelo juiz de paz da Freguesia da Lagoa, pois ele concedeu o direito à realização do reinado africano. No dia 11 de janeiro de 1843, a Câmara remeteu um ofício ao presidente da província, o marechal Antero José Ferreira de Brito, e comentou a autorização para a realização do reisado de escravos ocorrido em 26 de dezembro de 1842. No documento, foi relatado o desprezo que o juiz da Freguesia da Lagoa teve pelas leis:

Ill. ${ }^{\text {mo }}$ e Excelentíssimo Senhor - Pelo Artigo 104 das Posturas Municipaes estão prohibidos os ajuntamentos de escravos africanos para suppostos reinados, no termo deste Município e tendo o Artigo 132 do Regulamento Policial de 31 de Janeiro de 1842 converttido aos Juízes de Direito, Delegado e Subdelegado a incumbência de prohibir os espectaculos e ajuntamentos públicos, que não estiverem authorizados na forma do Artigo 66 parágrafo 12 da Lei de 1ㅇ de Outubro de 1828; foi com surpresa que a esta Câmara Municipal veio o ofício incluso datado de 5 corrente em que o Juiz de Paz da Freguesia da Lagoa, dá conta de haver se consentido a reunião de escravos, e aos suppostos reinados naquela Freguesia no dia 26 de Dezembro passado, sem que para isso procedesse a authorização de que trata o referido Artigo de Lei do $1^{\circ}$ de Outubro de 1828, a sim existindo a expressa prohibição do mencionado Artigo 104 das Posturas.

Hum tal acontecimento, que revela desprezo das Posturas da parte das authoridades que naquela Freguesia é [sic] incumbida de faze-las effectivos; julga esta Câmara de seu dever levado ao conhecimento de V. Ex. ${ }^{a}$ para que V. Ex. ${ }^{a}$ se sirva mandar dar as providencias que julgar acertadas, a fim de que essa, e as de mais authoridades policiaes deem as disposições sobre a policia dos districtos a execução, que devem, e são obrigados [...]. ${ }^{22}$

B.C). Registro de um ofício ao Juiz de Paz da Freguesia da Lagoa, 15 de dezembro de 1842. p. 164 verso. Mantive a grafia original do documento, modificando apenas algumas abreviações.

22 AHMF. Registro da Correspondência da Câmara Municipal, 1840/1843. NA no 85 (143 B.C). Registro de um ofício ao Excelentíssimo Presidente da Província, 11 de janeiro de 1843. p. 171 verso - 172. 
Não possuímos a continuação do caso, mas o que podemos concluir desse pequeno trecho é que, mesmo com a proibição expressa nas leis, as autoridades divergiam no que diz respeito à permissão da festa, que, ao que tudo indica, ocorreu na Freguesia da Lagoa, no período do Natal, data importante que marcava o momento de celebração para africanos e crioulos, escravos ou não - e com o consentimento do juiz de paz da Freguesia. Nessa intricada postura das autoridades frente ao proibir ou permitir as festas, havia algumas permissões pessoais que contornavam as leis e produziam uma "brecha" para que os fetejos fossem realizados.

Em 1850, a Câmara Municipal de Desterro remeteu uma correspondência ao inspetor da alfândega, para que ele deliberasse sobre o caso de um grande batuque que teria ocorrido nas ruas da cidade na noite de 31 de dezembro de 1849, com a permissão do subdelegado de Desterro, Amaro José Pereira - note-se que a data coincide com o Ano Novo, momento também descrito pelos viajantes no início do século XIX. No dia seguinte, a licença foi cassada pelo fiscal da Câmara.

Ill ${ }^{\text {mo }}$ Srn. A Câmara Municipal desta cidade, em sessão do dia 2 do corrente deliberou que se remetesse a V.S. ${ }^{a}$ a licença junta concedida por Amaro José Pereira Subdelegado de Policia desta cidade, ao abrigo do qual houve na noite do dia 31 do mês próximo passado um grande batuque pelas ruas da cidade, cassada no dia seguinte aos indivíduos no verso da mesma pelo Fiscal da Câmara, para que V.S. ${ }^{a}$ se sirva deliberar como entender. Deus Guarde a V.S. ${ }^{a}$ Desterro em 4 de Janeiro de $1850 .^{23}$

O subdelegado Amaro José Pereira permitiu a festa, mas a licença foi cassada no dia seguinte pelo fiscal da Câmara, que acabou preso pelo subdelegado. Na cadeia da cidade, o fiscal relatou os fatos:

Tendo eu tido noticia que na noite de hontem 31 do passado mez de Dezembro sahira uma reunião de dança de boi ou o que quer que seja; e tratando indagar que licença tinha sido dada para tal brincadeira, pude obter a licença inclusa que por ter sido dada contra o disposto do Art. 37 do Código de Posturas. Acontece que fui chamado pelo

23 AHMF. Registro da Correspondência da Câmara Municipal desta Cidade às Autoridades Civis e Fiscais do Município. 1848. AH N. 108 (129 B.C). p. 103 (verso). Mantive a grafia original do documento, modificando apenas algumas abreviações. 
subdelegado Amaro José Pereira por hum mandado, com o fim de hir a sua presença para indagações Policiais, e chegando a caza do subdelegado, este exigio de mim a licença, e como a não tivesse logo para lhe dar, ordenou a prisão, e agora me acho prezo nesta cadeia. Levo pois este facto ao conhecimento de V.S para o fazer junta a Camara para deliberar a respeito. Deos Guarde a V. S. Cadeia da Cidade do Desterro ao $1^{\circ}$ de Jan. de $1850 .^{24}$

Pelos documentos, não sabemos ao certo de que tipo de festa se tratava, nem se era exclusivamente africana. Primeiro, foi descrita como um "grande batuque pelas ruas da cidade"; e o fiscal da Câmara a definiu como uma "reunião de boi ou qualquer coisa que seja". Mas é importante evidenciar a divergência entre as autoridades, que desta vez, resultou na prisão do fiscal. Estes episódios fazem crer que as posturas não eram muito claras, ou eram suscetíveis de interpretações.

As divergências e ambiguidades na maneira de aplicar a lei não eram exclusivas da cidade de Desterro. Estudos referentes às cidades da Bahia e do Rio de Janeiro da primeira metade do século XIX demonstram que conceder ou reprimir os festejos dependiam das circunstâncias. Para algumas autoridades, era um padrão normativo, uma maneira de aliviar as tensões cotidianas da escravidão; para outros, representavam o seio da revolta social, um espaço para a resistência cultural e política, um perigo para a ordem pública. Todos, porém, tinham como objetivo estabelecer uma estratégia de controle social. ${ }^{25}$ A conivência de algumas autoridades, tanto na Bahia quanto no Rio - e também na cidade de Desterro - ilustram uma possibilidade de negociação entre os escravos e os responsáveis pela aplicação das leis, fazendo emergir, em meio a uma sociedade escravista e tipicamente católica, certa barganha e a tentativa dos escravos de dar continuidade às suas festas, que há tantos anos aconteciam, como vimos, em grande parte do território brasileiro. ${ }^{26}$

O Rio de Janeiro, maior cidade do país e capital do Império, recebeu um grande contingente de africanos até a década de 1850. Não

\footnotetext{
24 AHMF. Série: Requerimentos Diversos, Correspondências e Ofícios. Pasta 11 a 15. Pasta 12. Requerimento à Câmara Municipal de 01 de janeiro de 1850. Mantive a grafia original do documento, modificando apenas algumas abreviações.

25 REIS, 2001, p. 106.

26 ABREU, 1994, p. 116. Ver SILVA, 1989, p. 33.
} 
menos expressivo era o caso da Bahia, que também concentrava um grande número de escravos e, desde o final do século XVIII até meados do XIX, convivia com a tensão de possíveis revoltas escravas. Guardadas as proporções, o que pretendemos demonstrar, mesmo que com escasso número de fontes, é que em Desterro, essas ambiguidades estavam presentes entre as autoridades da cidade, num período marcado por transformações na sociedade brasileira, no qual novas leis tentavam cercear as manifestações dos escravos e seus descendentes. Algumas permissões pessoais contornavam a legislação e nos fazem supor que os escravos viam nessa situação uma chance de negociação, para fazer com que algumas autoridades concedessem a autorização, mesmo que as festas estivessem expressamente proibidas. Por trás dessas divergências e ambiguidades, é possível perceber que toda a diversidade das festas era mantida, que os batuques e os reinados ainda aconteciam e se tornavam motivos de preocupação por parte de algumas autoridades.

Até mesmo as festas no interior das irmandades não eram mais toleradas. Desde 1844, não se praticavam as eleições de reis durante a festa de Nossa Senhora do Rosário, em virtude da mudança do compromisso da instituição. Mesmo assim, os irmãos tentaram negociar uma possível permissão para voltar a festejar a padroeira pelas ruas de Desterro. Porém, a posição das autoridades foi muito diferente daquelas relatadas pelos viajantes estrangeiros. No dia 29 de abril de 1853, foi levada à comissão de Câmaras da Assembleia Provincial uma petição feita pelos mesários da irmandade "[...] alegando o estado de progressiva decadência e pobreza em que v[inha] caindo o templo dedicado a Nossa Senhora por falta de socorros provenientes das esmolas que davam os irmãos africanos [...]". ${ }^{27}$ Os mesários pediram aos representantes da Assembleia Provincial que permitissem "aos africanos irmãos daquela irmandade gozarem do prazer de se divertirem nos domingos e dias santos de guarda, uma vez que não ofenda a moral pública conforme seus usos e representações dos seus reis e outros personagens [...]". Para os representantes da Assembleia, "desde tempo imemorial", era permitido aos africanos e crioulos os divertimentos por ocasião da festa de Natal. E era fato também que o

27 ARQUIVO PÚBLICO DO ESTADO DE SANTA CATARINA (APE/SC). Pareceres da Comissão de Câmaras Municipais, 1848-1867. Parecer de 29/04/1853. As próximas citações provêm desse documento igualmente. 
divertimento passou a ser proibido por ser repulsivo "ao estado de civilização" da população. Nesse sentido, aos olhos das autoridades, cabia ficar no passado tal prática, que para elas representava uma ameaça ao sossego público. Suas argumentações criavam um cenário de temor e desordem, uma visão típica da elite no pós-independência:

\begin{abstract}
A indecência das danças de quasi todas as nações africanas que offendia a moral as desordens que se originarão da embriaguez de muito d'esses indivíduos, o choque resultante do encontro de uma com outra nação que nesse encontro se disputavão a precedencia no passo, a rivalidade rancorosa que se entre ellas desenvolvia por occazião d'esse divertimento, cauzas estas que bastante fazia tremer pela tranqüilidade publica em ocasioens tais muito ameaçada e além disto a repulsa que detaes divertimentos fazia o estado de civilização a que tinhamos chegado, forão por sem duvida os poderosos motivos que aconselharão a Câmara Municipal a prohibilos, como afez pelo Art. 38 do seu Código de Posturas approvado pelo decreto no 222 de 10 de maio de 1845 . Foi pois essa prohibição uma verdadeira medida de salvação publica, porque por meio dela prevenio-se males cuja existencia teria de ser assaz lamentavel. ${ }^{28}$
\end{abstract}

Este parecer, por fim, faz uma ligação com tudo o que foi analisado até aqui. Vimos, através dos relatos dos viajantes, a paisagem que se formava nas ruas de Desterro no final de ano. Nas festas, representadas com muita emoção, estavam presentes danças, instrumentos e vestimentas próprias. A música existira nas ruas e teria continuado através das representações de "reis e outros personagens", porém, a conjuntura era outra. Permissão e proibição estavam presentes em Desterro e, aos poucos, os cercos foram sufocando as diversões de fim de ano dos cativos. Após 1830, os documentos não revelam detalhes das festas, mas pela primeira vez, aparece registrada nas correspondências das autoridades a especificação da festa de reisado africano, que parecia ocorrer dentro e fora da irmandade; outros casos evidenciam a presença de batuques na cidade.

\footnotetext{
28 Ibidem. Mantive a grafia original do documento, modificando apenas algumas abreviações.
} 
A permissão dos homens de mando para que os festejos acontecessem, mesmo estando proibidos nas leis e normas de postura, evidenciam uma possibilidade de mobilização e barganha dos escravos. Entretanto, as regras do jogo estavam mudando; a Irmandade de Nossa Senhora do Rosário deixou de realizar suas festas em 1844, e em 1853, os representantes da Assembleia colocaram um ponto final em qualquer tentativa de festejos por parte da irmandade. A justificativa para a proibição dos batuques e das festas de coroação de reis negros seguia a prática moralizante daquele momento; marca a ruptura com um período no qual ainda se permitia aos africanos e seus descendentes os divertimentos por ocasião do Natal, para uma Desterro que deveria ser guiada pelas leis, em busca da prática do "sossego público". ${ }^{29}$

Cada vez mais, as tentativas de cerceamento a qualquer ajuntamento de escravos e libertos, principalmente de africanos, foram se tornando nítidas; e as festas no período do Natal, com toda pompa, tambores e danças, fadadas a ficarem nos "tempos imemoriais" - como aqueles descritos pelos viajantes no início do século XIX.

\section{Fontes}

1) Manuscritas

\section{ARQUIVO HISTÓRICO MUNICIPAL DE FLORIANÓPOLIS}

Registros de Leis Imperiais para Câmara Municipal. 1828-1829.

Registro da Correspondência da Câmara Municipal, 1840-1843.

Registro da Correspondência da Câmara Municipal desta Cidade às Autoridades Civis e Fiscais do Município. 1848.

Série: Requerimentos Diversos / Correspondências e Ofícios. Pasta 11 a 15. Pasta 12. ARQUIVO HISTÓRICO DA ASSEMBLEIA LEGISLATIVA DE SANTA CATARINA Ofícios - 1835-1848. Escravos.

Desterro, Código de Posturas. Lei no 222 de 10 de maio de 1845.

ARQUIVO PÚBLICO DO ESTADO DE SANTA CATARINA

Pareceres da Comissão de Câmaras Municipais, 1848-1867.

29 SOUZA, 2002, p. 247-278. 
2) Impressas

COMERLATO, Fabiana; MORTARI, Cláudia. Transcrição de diversos Manuscritos referentes à Irmandade de N. S. do Rosário e de N. S. do Parto. Provedor: Sr. Oscar Paulo de Souza. Ilha de Santa Catarina, 2000.

\section{Referências}

ABREU, Martha. Festas religiosas no Rio de Janeiro: perspectivas de controle e tolerância no século XIX. Estudos Históricos, v. 7, 1994, p. 183-203.

ANDRADE, Marcos Ferreira de. Rebelião escrava na Comarca do Rio das Mortes, Minas Gerais: o caso de Carrancas. Afro-Ásia , n. 21-22, 1998-1999, p. 45-82.

CORRÊA, Carlos Humberto P. História de Florianópolis - Ilustrada. 3 ed. Florianópolis: Insular, 2005.

HARO, Martim Afonso Palma de (Org.). Ilha de Santa Catarina: relatos de viajantes estrangeiros nos séculos XVIII e XIX. 4. ed. Florianópolis: Editora da UFSC/Editora Lunardelli, 1996.

MALAVOTA, Claudia Mortari. Os homens pretos de Desterro. Dissertação (Mestrado em Filosofia) Instituto de Filosofia e Ciências Humanas, Curso de Pós-Graduação em História da Pontifícia Universidade Católica do Rio Grande do Sul. Porto Alegre, 2002.

REIS, João José. A morte é uma festa: ritos fúnebres e revolta popular no Brasil do século XIX. São Paulo: Companhia das Letras, 1991. Identidade e diversidade étnicas nas Irmandades negras no tempo da escravidão. Tempo. v. 2, n. 3, 1996, p. 7-33. . Tambores e temores: a festa negra na Bahia na primeira metade do século XIX. In: CUNHA, Maria Clementina Pereira (Org.). Carnavais e outras $f(r)$ estas: ensaios de história social da cultura. Campinas: Editora da Unicamp/ CECULT, 2001.

SILVA, Eduardo. Entre Zumbi e Pai João, o escravo que negocia. In: REIS, João; SILVA, Eduardo. Negociação e conflito: a resistência negra no Brasil escravista. São Paulo: Companhia das Letras, 1989.

SOUZA, Marina de Mello e. História, mito e identidade nas festas de reis negros no Brasil - século XVII e XIX. p. 249-260. In: JANCSÓ, István; KANTOR, Irís (Org.). Festa: Cultura e sociabilidade na América portuguesa. São Paulo: Edusp / Imprensa Oficial. v. I, 1999. 
SOUZA, Marina de Mello e. Reis negros no Brasil escravista: história da festa de coroação de rei congo. Belo Horizonte: Editora UFMG, 2002.

TINHORÃO, José Ramos. Os sons dos negros no Brasil: cantos, danças, folguedos; origens. São Paulo: Art, 1988.

VIANNA, Larissa. O idioma da mestiçagem. Campinas: Editora da UNICAMP, 2007. 


\section{|| Capítulo 6 ||}

\section{Quilombos e fugas de escravos na Itha de Santa Catarina}

Martha Rebelatto

Ninguém gostava de ser escravo de outra pessoa. Ter que trabalhar forçado e não ganhar nada ou muito pouco, estar sujeito a castigos, sofrer ameaças constantes, não poder sair sem permissão nem visitar as pessoas queridas ou amigos. Mas fugir era bastante arriscado, e havia quem trabalhasse só para recapturar escravos fugitivos. O jeito era negociar condições aceitáveis de sobrevivência. Mesmo assim, sempre houve quem fugisse por alguns dias apenas ou mesmo para bem longe. A Ilha de Santa Catarina, com pequenos núcleos urbanos e muitos espaços de floresta ainda desocupados e, ao mesmo tempo, porto de passagem de navios que trafegavam pelo Atlântico sul, oferecia diferentes opções para os escravos que planejavam e também para aqueles que aproveitavam oportunidades para fugir dos seus senhores ou da escravidão.

Nos jornais de época, é fácil encontrar anúncios de cativos fugitivos, que costumavam ter a imagem de um negro com uma trouxinha nas costas e oferecer um prêmio para quem desse alguma informação que ajudasse na captura. O anúncio da fuga no jornal - meio de comunicação mais amplo da época - aumentava as chances de o senhor capturar o fujão, e pressionava o escravo a se esconder para não ser visto e delatado. Se tivesse amigos ou conhecidos que pudessem ajudar, ficava mais fácil para se abrigar. Outra opção era buscar apoio em quilombos que, na Ilha de Santa Catarina e no Brasil, de modo geral, eram pequenos e pouco estruturados, mas serviam como abrigo, se não definitivo, ao menos temporário. 
Durante o século XIX, os quilombos estiveram presentes na ilha de Santa Catarina em diferentes momentos e locais. Os escravos aquilombados podiam ou não aceitar a presença de outros foragidos, não apenas cativos, como fugitivos da justiça; todavia, sabemos muito pouco sobre a forma de organização dos quilombos. A associação que frequentemente fazemos em nossas mentes, aplicando a imagem de Palmares, o quilombo mais conhecido dos brasileiros, a todos os demais não é inteiramente verdadeira. A maioria dos ajuntamentos de escravos fugitivos tinha uma estrutura bem simples, eram locais de passagem, abrigos temporários, enquanto o escravo decidia que rumo tomaria.

A frequência com que os quilombos aparecem na documentação, geralmente de polícia, é mais intensa até as imediações do ano de 1850. Durante a primeira metade do século XIX, o número de escravos vindos de outras províncias era maior, fossem africanos ou crioulos (escravos nascidos no Brasil). Esses cativos haviam sido separados dos seus parentes e amigos pelo tráfico atlântico (externo) ou interprovincial (interno) e, provavelmente, ainda não tinham refeito laços familiares ou de amizades que os prendessem ao cativeiro. Essa ligação frouxa com o novo local de residência e a lembrança de um passado ainda próximo, perto de pessoas queridas, estimulava alguns cativos à fuga. Com o passar do tempo, entretanto, o escravo criava relações íntimas dentro do escravismo, o que poderia influenciar em sua permanência junto a amigos e familiares, desestimulando a fuga. Além disso, o maior conhecimento do cativeiro (senhor, localidade, forma de trabalho, regras etc.), adquirido com o transcorrer do tempo, ampliava a possibilidade de o escravo barganhar, lutar por melhorias nas suas condições de trabalho e de vida. Uma fuga envolvia inúmeros riscos, e os escravos tinham consciência das possíveis consequências de tal ato; dessa forma, antes de optar pela fuga, o escravo ponderava os prós e os contras dessa atitude e, assim, escolhia o caminho que acreditava ser o melhor para si, de acordo com as suas condições de vida e expectativas.

Os primeiros indícios de quilombos na ilha de Santa Catarina datam de 1751, quando, através de um regulamento, foram estipulados valores a serem pagos pela captura de escravos fugitivos. A fuga e, mais 
precisamente, a proteção encontrada pelos escravos em quilombos era um problema sério para toda a sociedade, que se estruturava na posse de escravos. Os senhores ficavam sem seus trabalhadores, as autoridades locais demonstravam fraqueza no cumprimento do seu dever de manter a ordem, e a população próxima aos quilombos temia saques e roubos. Os quilombolas eram responsabilizados por roubos, mortes e perturbações. O imaginário sobre eles contribuía para que a população em geral temesse os ataques e assaltos de negros fugidos, mesmo quando estes não ocorriam ou não se faziam perceber.

Assim, o regulamento de 1751 era uma ferramenta no combate à fuga, uma vez que oferecia uma gratificação para que pessoas comuns ajudassem as autoridades policiais no trabalho de captura. O ofício de capitão do mato também era um instrumento para tentar diminuir as fugas e intimidar os escravos. As medidas tomadas para combater os quilombos, além do objetivo direto de desmobilizá-los, funcionavam de forma preventiva, pois criavam mais obstáculos ao sucesso da fuga. Em outras palavras, o escravo que pretendia fugir ou o quilombola que planejava o roubo de mantimentos, por exemplo, tinha que considerar a possibilidade de seu plano fracassar e ter de retornar às mãos de um senhor que, certamente, estava descontente com a sua fuga. A presença do capitão do mato, e mesmo de indivíduos que ganhavam dinheiro capturando fugitivos, com certeza aumentava as chances de fracasso do plano de fuga; e os cativos tinham consciência deste fato.

Segundo o Registro de Provisões de 1751, era considerado quilombo todo local que possuísse "ranchos, negros, armas, ferramentas, panelas, pilão". ${ }^{1}$ Estas especificações demonstram que um local era definido como quilombo quando tinha certa estrutura, que não precisava ser algo muito elaborado. Ranchos poderiam ser compreendidos apenas como abrigos simples para a proteção das intempéries. Os utensílios, provavelmente furtados pelos cativos antes da fuga, eram necessários para o preparo de alimentos. As armas poderiam ser utilizadas tanto para a defesa do local quanto para a caça de animais, englobando, conforme o documento, armas de fogo, tochas e até bastões de madeira.

\footnotetext{
ARQUIVO HISTÓRICO MUNICIPAL DE FLORIANÓPOLIS. Registro de Provisões, Câmara de Desterro, 1871. Livros Históricos, A.H. no 318 (153 B.C.), páginas 12 e 13.
} 
Os valores a serem pagos pela captura de escravos fugitivos na ilha de Santa Catarina e redondezas, em 1751, eram os seguintes:

Por cada escravo ribeirinho que se apanhar desde o Saco do Itacorubi, Rio Pirajubaé pelo Morro da Vila.......................... 1\$280

Pelo escravo que se apanhar de Caiacanga, Freguesia da Lagoa, São José, Cacupé. $2 \$ 560$

Pelo escravo que se apanhar até a Igreja da Cachoeira Manoel de Piar Caiacangaçu $3 \$ 200$

Pelo escravo que se apanhar desta paragem, $C^{\text {a }}$ forra e de Barra de Dentro. $.5 \$ 000$

Quanto mais distante da povoação de Desterro, maior era o montante pago, chegando a quase quadruplicar nos locais mais inóspitos. A diferença dos valores estimulava o capitão do mato a vasculhar em locais mais distantes, algumas vezes, de difícil acesso, visto que receberia uma recompensa maior pelo esforço. No século XIX, a Ilha de Santa Catarina era formada por diversos núcleos de povoamento, sendo os principais Nossa Senhora do Desterro (na parte mais próxima ao continente, onde se formava um estreito na baía); Nossa Senhora das Necessidades de Santo Antônio (na Baía Norte); Nossa Senhora da Lapa do Ribeirão (na Baía Sul); Nossa Senhora da Conceição da Lagoa (no interior, estendendose para o leste da ilha); e São Francisco de Paula de Canasvieiras (no norte da ilha). A comunicação por terra entre os núcleos era difícil, pois além de montanhosa, a ilha era coberta de vegetação e pontilhada de mangues. Com o passar do século XIX, a paisagem foi sendo transformada pelo avanço do cultivo agrícola. Nesse contexto, a estratégia de recompensas conforme as dificuldades pode ter sido utilizada pelas autoridades, caso o local de captura fosse distante, com pouca movimentação de pessoas ou condições naturais adversas (matas, mangues etc.). Os riscos para o capitão do mato englobavam desde as dificuldades de acesso a determinados locais até o perigo de emboscada ou ataque, que era maior em lugares isolados. Além de regularizar o pagamento, esse documento abre espaço para pensarmos quanto à circulação dos escravos na ilha. A movimentação poderia dificultar a captura, mas para isso, o cativo precisava conhecer o espaço com o qual estava interagindo. Assim, é bem possível que os cativos tivessem o conhecimento espacial da ilha de uma 
forma geral e conseguissem transitar com certa destreza de um lado para outro (logicamente observadas às limitações da época). Voltaremos a esse tópico um pouco mais adiante, quando tratarmos dos anúncios de fuga.

Muitos atos cometidos pelos quilombolas, principalmente os roubos, atormentavam a polícia e os moradores próximos a seus esconderijos, tanto por serem considerados perigosos como pelo possível incentivo a novas fugas. Os saques e furtos cometidos pela população quilombola foram a justificativa para que autoridades e senhores trabalhassem juntos, muitas vezes, para destruir os quilombos. Foi o que ocorreu na Freguesia da Lagoa, em agosto do ano de 1822. Segundo os moradores, os negros reunidos em um quilombo furtavam os mantimentos de que necessitavam para sua sobrevivência. A localização precisa do quilombo não era conhecida, o que dificultava o trabalho da polícia e do capitão do mato. A região da Lagoa possui vários morros encobertos por mato, que proporcionavam uma proteção natural, bem como uma visão privilegiada. A boa visibilidade alertava os quilombolas sobre a aproximação da polícia, do capitão do mato ou de quem quer que fosse, facilitando a mobilização para o combate ou a fuga.

Ainda no ano de 1822, em dezembro, havia novos indícios de quilombos. A correspondência trocada entre autoridades do governo fala sobre a autorização de uma nova busca a vários locais da ilha onde se achavam aquilombados "pretos fugidos". No mesmo ano, o juiz de fora apresentou reclamações a respeito do crescente número de escravos fugitivos que se escondiam em bosques, formando "corporações ilícitas", que, segundo ele, causavam perturbações aos direitos sociais e ao sossego do povo. Os quilombos, ali chamados de "corporações ilícitas", são descritos como perturbadores tanto do direito social (escravidão) como do sossego (pela insegurança que causavam, especialmente, nas suas redondezas).

Assim como o quilombo da Lagoa, outro, denominado Faxinal, aparece frequentemente nos documentos policiais durante a primeira metade da década de 1840. Em 2 de agosto de 1842, as autoridades provinciais trocaram correspondências relatando que, no distrito da Lagoa, na parte próxima ao Rio Tavares e também em um local denominado Faxinal (que infelizmente ainda não conseguimos identificar), os negros aquilombados estavam roubando roças e gado na vizinhança. Os saques 
e roubos eram típicos dos quilombos com estrutura menor, geralmente sem plantações ou criação de animais para alimentar seus integrantes. Era uma situação difícil para os quilombolas, pois com certeza sabiam que os assaltos provocariam uma reação da sociedade; em concomitância, não tinham condições de se manter por muito tempo isolados nas matas. Esse parece ter sido um dos problemas centrais encontrados pelos quilombolas na Ilha de Santa Catarina. A alimentação escassa levava a pequenos e constantes furtos, o que aborrecia a população, que buscava apoio da polícia para acabar com o refúgio dos negros e, consequentemente, diminuir os danos que causavam, bem como eventualmente recuperar a posse de algum escravo que havia abandonado o cativeiro. Tais ocorrências se sucediam naquele momento; o roubo de gado e roças passara a incomodar os moradores, que se viam lesados, e resolveram tomar medidas para desmobilizar os quilombolas e restituir a posse dos cativos a seus senhores. Naquele contexto, não podemos esquecer que a escravidão era considerada aceitável pela grande maioria da população livre, especialmente na primeira metade do século XIX. Assim, a fuga em si já era passível de repreensão; roubos à propriedade eram mais um agravante.

Como geralmente tomamos conhecimento da existência dos quilombos a partir de relatos policiais, permanecem desconhecidos os quilombos que não sofreram ataques, pois não preocuparam ou mesmo nem chegaram ao conhecimento da sociedade. Ao que tudo indica, foram vários os quilombos na Ilha de Santa Catarina e seus arredores. Muitos documentos policiais fazem referência à necessidade de buscas e apreensão a escravos fugitivos reunidos em quilombos. Contudo, a maioria não define o local exato destes. Isso nos faz crer que os ajuntamentos de escravos poderiam possuir certa mobilidade e uma estrutura pouco complexa, o que dificultava a sua localização por parte de moradores e das autoridades locais. Além do mais, como são quase inexistentes os relatos sobre o resultado das buscas para capturar quilombolas, isso nos faz crer que a maioria das empreitadas falhou no seu objetivo. A estrutura rudimentar dos acampamentos e o de tais buscas provavelmente ajudavam na mobilidade, assim, quando os quilombolas se sentiam ameaçados, migravam para outro local, às vezes, próximo, mantendo o local de seu refúgio anônimo. 
Não devemos imaginar que todo escravo descontente fugia, nem mesmo que toda fuga acabava em um quilombo. Os escravos tinham muitas estratégias para tentar melhorar sua condição: alguns optavam pela fuga definitiva, outros buscavam melhorias dentro do próprio cativeiro. Entre as opções as condições de vida e trabalho, estava a fuga temporária, que era usada como instrumento de negociação e protesto. Essas escapadas mostravam ao senhor que o cativo não estava contente com determinada situação, que desejava mudanças para voltar ao trabalho. As pequenas fugas podiam durar dias, semanas ou até meses e, geralmente, o escravo retomava suas atividades após ter seu objetivo alcançado. O retorno ao trabalho costumava vir acompanhado de uma dupla promessa por parte do senhor: 1) Conceder algum incentivo à volta (relacionada ao motivo da fuga); 2) Garantias de que o fujão não seria castigado ao retornar a rotina de trabalho. Os motivos que levavam os escravos a estas escapadas - a fugir não somente do trabalho, mas das vistas do senhor por um tempo - estavam relacionados a situações específicas, uma mudança que desagradou o cativo ou a proibição de algo que este considerava seu direito. Por exemplo, uma venda (tanto quando o cativo desejava permanecer em posse do mesmo senhor, que ameaçava vendê-lo, quanto se o escravo estava descontente e queria motivar seu senhor a vendê-lo); uma punição considerada exagerada; o afastamento de amigos ou pessoas queridas etc. O mais importante é pensarmos a fuga não apenas como algo definitivo, mas como estratégia de negociação.

Os senhores sabiam que o escravo podia voltar espontaneamente ao trabalho após uma fuga, assim, geralmente esperavam alguns dias. Quando isso não ocorria, eram publicados anúncios em jornais locais relatando a fuga e descrevendo o fugitivo em detalhes. Os avisos de fuga dividiam espaço com todo tipo de anúncio: venda de propriedade, divulgação de espetáculos, oferta de algum produto, medicamentos etc. Os relatos de fuga feitos pelos senhores seguiam um padrão, informando sobre as características físicas do escravo, roupas que usava no dia da fuga, se possuía marcas ou deficiências facilmente identificáveis. Comumente, informava-se sobre o proprietário do escravo, mas quando isso não ocorria, era disponibilizado um endereço ao qual as pessoas que tivessem informações deveriam se dirigir, ou no qual o cativo deveria ser entregue, caso capturado. Era muito comum a oferta de recompensas. 
A seguir, exemplos de anúncios de fuga retirados dos jornais $O$ Novo Íris, de 1851, e A Província, de 1871:

Ao abaixo assinado, no dia 9 do corrente mês, fugiu da Freguesia do Ribeirão, um escravo crioulo de nome Camilo, meio fula, magro, estatura regular, alguma barba no queixo já branca e uma cicatriz na face direita contra o nariz; levou camisola da baeta azul, camisa branca, calça de castor escuro em xadrez: tem os tornozelos meio grosso, e foi escravo de Joaquim Antônio de Souza morador na Guarda de Embaú. Como há todas as provas do dito escravo estar naquele lado, o anunciante protesta contra quem o tiver acoitado, e gratificara a quem apresentá-lo nesta freguesia a seu senhor, que também o vende.

Freguesia de Ribeirão, 21 de Junho de 1851.

Francisco Antonio da Silva.

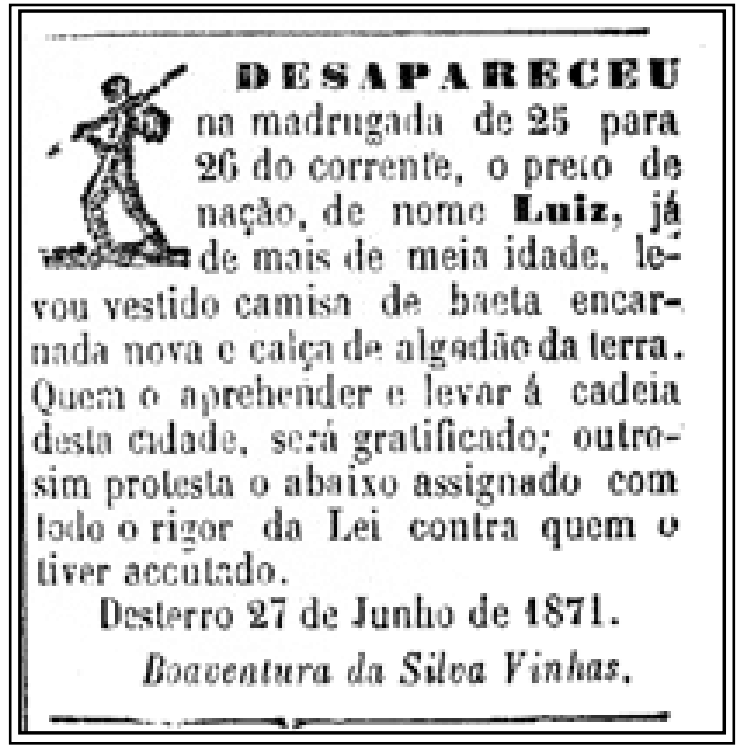

Os dois anúncios representam apenas exemplos da forma como o escravo fugitivo era descrito. O primeiro traz informações do senhor, uma breve descrição física do cativo, o relato das roupas que levou consigo - o 
que poderia facilitar na sua identificação - e a promessa de gratificação. Ademais, o senhor relata conhecer o rumo que o cativo tomou. O retorno do escravo a um local onde trabalhara em um período anterior é muito comum e, como mencionamos, poderia se tratar de uma visita com data marcada para acabar ou uma tentativa de forçar o senhor a vendê-lo, na esperança de ficar próximo a pessoas queridas. A venda realmente está em jogo neste caso, uma vez que o senhor fala claramente, no final do aviso, que pode vender o cativo. O segundo anúncio é muito parecido, descrevendo o escravo e as roupas que levou. Neste, o senhor solicita que o cativo seja entregue na cadeia. Embora a cadeia fosse um local adequado a receber os fugitivos, nem sempre era a melhor opção para os senhores. Como os escravos eram propriedade de alguém, seus atos eram responsabilidade do dono. Assim, os prejuízos que a administração da cadeia tivesse com o cativo (especialmente alimentação), enquanto aguardava que o senhor viesse resgatá-lo, eram cobrados do proprietário. Por isso, estes preferiam oferecer um local alternativo para a entrega do escravo fugido. Normalmente, aparece nos anúncios a seguinte frase: "protesta-se contra quem o tiver acoitado" tinha o objetivo de criticar as pessoas que pudessem dar cobertura às fugas, funcionando como uma espécie de ameaça. O escravo poderia conseguir ajuda de diversas formas, tanto através de relações de amizade quanto de trabalho, oferecendo seus serviços por um tempo.

A maioria dos anúncios, entre 1849 e 1888, relatava a fuga de escravos do sexo masculino e já adultos. Dos 156 fugitivos encontrados, 124 eram homens e 32 eram mulheres. Essa diferença pode ser entendida dentro do cenário vivido pelos escravos na Ilha de Santa Catarina no século XIX. A primeira explicação é que as mulheres representavam um número menor na população escrava; como segundo motivo, o fato de que uma mulher com filhos tinha mais dificuldade em abandonar o cativeiro. Uma fuga com crianças com certeza era mais difícil. Fugir não era tarefa fácil, por conseguinte, muitas mulheres possivelmente preferiam não arriscar a vida de seus filhos em esconderijos precários, com falta de alimentos, vestimentas, enfim, nas condições rígidas da maioria das fugas. Da mesma forma, abandonar as crianças não era a melhor opção para essas mulheres. Ao que tudo indica, elas permaneciam em cativeiro e ali tentavam negociar e reivindicar melhorias para as suas vidas e a de seus filhos. 
O medo e a incerteza sem dúvida desencorajaram os escravos a fugir em diversas situações. Os cativos tinham consciência das adversidades pelas quais passariam até encontrar um abrigo seguro, e não seriam poucas: chuva, frio, falta de alimentos, cansaço físico, entre outras. Conseguir escapar da propriedade de seu senhor era apenas o primeiro passo da fuga. Sem um esconderijo, o escravo seria facilmente recapturado.

O caso do escravo fugitivo Bernardo mostra alguns possíveis refúgios. Em 1842, fugira de seu senhor, mas essa não era a primeira vez que isso acontecia. Manoel da Costa Pereira, proprietário do cativo, relatou, no comunicado que fizera à polícia sobre a fuga, ter conhecimento do possível esconderijo do seu escravo. Segundo Manoel da Costa Pereira, Bernardo tinha aproximadamente 30 anos, trabalhava como carpinteiro e já havia se escondido, durante fugas, na casa de um preto forro na Barra da Lagoa. Revoltado com as constantes escapadas do escravo, seu dono acabou por relatar à polícia outros locais onde eram feitas reuniões de escravos e onde estes encontravam abrigo durante as fugas. O preto que havia abrigado Bernardo era acusado de promover reuniões de escravos, que também ocorriam no Canto de Manoel Vieira e no Rio Tavares. Manoel da Costa Pereira também indicou um local na Palhoça, no continente, onde os fugitivos encontravam abrigo. Tratava-se da casa do major Anacleto José Pereira da Silva, que permitia o ajuntamento de escravos fugitivos, acolhidos ali por um preto chamado Catráhio, "alcunhado de mandingueiro". ${ }^{2}$ O relato de Manoel da Costa Pereira "mapeia" alguns dos lugares nos quais os escravos sabiam que encontrariam apoio e cobertura em caso de fuga. Essas casas eram mais do que pontos de esconderijo, eram locais de encontro. Isso significa que os escravos, alguns pelo menos, conheciam-se, eram amigos e se encontravam com regularidade para conversar, articular fugas, informar-se sobre situações referentes à escravidão, dançar etc.

A vida dos escravos era muito mais complexa do que apenas trabalhar. Os cativos buscavam, o tempo todo, dentro das limitações impostas pelo escravismo, manter relações sociais, fossem elas de amor, amizade, companheirismo etc. A convivência com pessoas queridas, a

2 ARQUIVO DO ESTADO DE SANTA CATARINA. Registro das Correspondências do Presidente da Província para os Juízes. 1835/ 1876. Acervo no 1, Estante 3D, caixa 24. Fl.56/57. 
possibilidade de praticar algumas de suas crenças ou mesmo ter um tempo para o lazer era o que tornava o cativeiro, de certa forma, tolerável. Quando esse convívio social era boicotado de alguma forma pelos senhores, os castigos eram demasiados ou o escravo considerava determinada atitude inaceitável, a fuga aparecia em cena como uma possibilidade, tanto para demonstrar essa insatisfação ao senhor quanto para tentar romper aquele cativeiro. Era necessário que o cativeiro oferecesse condições aceitáveis de sobrevivência, e estas muitas vezes iam muito além do trabalho duro, que podia ser aceito desde que o escravo tivesse garantido o acesso a outras atividades que apreciava. Como vimos, os laços de amizade podiam ajudar o escravo a suportar o cativeiro, mas também eram úteis em caso de fuga, quando o escravo precisava de alguém que o escondesse ou que interviesse em favor dele junto ao seu senhor.

\section{Fugas marítimas}

A geografia, a densidade demográfica, os meios de transporte e comunicação, entre outros fatores, influenciavam o modo de vida da sociedade e, por isso, devem ser observados cuidadosamente para melhor entendermos as opções e escolhas feitas pelos homens e mulheres que viveram no passado. Em um local como a Ilha de Santa Catarina, o mar e a grande circulação de navios pelo porto e ancoradouros que se espalhavam ao seu redor ofereciam aos escravos uma possibilidade inusitada de fuga. O porto movimentado - passagem entre as praças comerciais do Rio de Janeiro, Rio Grande do Sul e Buenos Aires, além de rotas de navios da costa leste americana para o Pacífico - oferecia aos escravos a possibilidade de uma rota de fuga marítima. Embarcar em um navio e ir embora com sua tripulação, com certeza era o sonho, se não de muitos, pelo menos de alguns cativos. Provavelmente, um cativo que conhecesse um pouco do trabalho no mar teria serviço garantido nas embarcações. Quando a fuga era realizada com êxito, tinha a chance de ir para longe de seu senhor e da sociedade que o conhecia, diminuindo muito, quase anulando, as chances de ser reconhecido e recapturado. A possibilidade de mudança era concreta nessa situação, mesmo que o escravo não tivesse certeza sobre o futuro que o esperava nos navios ou em outra localidade quando abandonasse a embarcação. 
A falta de mão de obra nos navios possivelmente era o motivo mais comum para que os capitães de navios nacionais e estrangeiros permitissem o embarque de escravos. Não podemos esquecer que a escravidão já havia sido abolida nas colônias britânicas (em 1834), nas colônias francesas (em 1848) e nos Estados Unidos (após a Guerra Civil, que durou de 1861 a 1865). Os marinheiros estrangeiros transportavam as notícias e os ideais de liberdade através do mar e, em alguns momentos, podem não apenas ter permitido fugitivos a bordo, como também incentivado as fugas. As embarcações estrangeiras mais comuns no litoral catarinense eram os barcos de pesca de baleia norte-americanos. Os barcos baleeiros, como eram chamados, frequentavam o litoral catarinense desde, pelo menos, 1801, quando foi permitida a todos os países a pesca da baleia no litoral brasileiro. A Ilha de Santa Catarina era um dos locais de parada destas embarcações enquanto pescavam em mares do sul.

O caso do escravo Fructuoso indica como eram planejadas estas fugas. Antes de trazermos o personagem à cena, vamos descrever um pouco desta incrível história. Em 1868, o brigue baleeiro Highland Mary of Sag Harbor deu fuga a sete escravos da Ilha de Santa Catarina. Estes conseguiram entrar na embarcação quando estava ancorada perto da Fortaleza de Santa Cruz, situada na baía Norte. A notícia da fuga coletiva tomou as páginas dos jornais, que relatavam diversos protestos de senhores indignados com a falta de vigilância da polícia. A história poderia acabar nesse episódio, mas o relato de um português, João Cardoso Jacques, que havia desertado do mesmo brigue americano, trouxe mais ação ao enredo da fuga. De acordo com o marinheiro João Cardoso, um dos tripulantes do brigue americano era um crioulo chamado Fructuoso, cativo da província de Santa Catarina, de onde havia fugido dois ou três anos antes em uma barca americana. A embarcação que dera fuga a Fructuoso era outra; o crioulo trocara de embarcação, nos Estados Unidos, passando para o baleeiro em questão. $O$ marinheiro português contou também ao chefe de polícia que ouviu dizer que Fructuoso tinha estado em terra, nas Freguesias de Canasvieiras e Santo Antônio, "seduzindo" escravos para completar a tripulação do navio, e que tinha conseguido levar alguns a bordo. Declarou também que quando o brigue era vistoriado, o capitão escondia o crioulo na sua própria câmara. 
O fato de Fructuoso ser utilizado para angariar novos escravos pode explicar o cuidado do capitão em escondê-lo de pessoas que poderiam reconhecê-lo e conduzi-lo a seu antigo senhor ou à prisão. Indica, ainda, que o capitão conhecia a situação de Fructuoso como cativo, e necessitando de tripulação, a "sedução" de escravos para ocupar estas vagas se configurava uma boa solução. Fructuoso tinha uma vantagem por ter sido - ou ser ainda, já que era fugitivo - escravo na província: sabia movimentar-se no meio, provavelmente conhecia mais escravos e tinha alguns contatos; conseguiria incentivar outros cativos a acompanhá-lo ao brigue americano. Não devia ser tarefa das mais difíceis encontrar escravos dispostos a abandonar o cativeiro e aceitar a oferta de embarcar.

Quando Fructuoso fugiu do cativeiro, em 1865, seu proprietário publicou um protesto no jornal O Despertador (27 de junho de 1865, n. 256), criticando a falta de fiscalização nos navios de partida, que dessa maneira, permitia a fuga de escravos. Reproduzimos parte dessas queixas:

No dia 20 deste mês, apontou em Santo Antonio uma lancha de um navio Norte Americano; e retirando-se à noite, desapareceram com ela dois escravos. Um crioulo de nome Fructuoso, escravo de João José da Cunha e Silva, e um pardo Joaquim, escravo de João Theodozio Machado; ambos os escravos habituados ao serviço do mar, sendo que o primeiro, há muito dizia que havia de fugir com os americanos. [...] O tratamento que recebiam esses escravos, que mais pareciam livres, é indício que só o desejo de viajar e correr mundo os levou a abandonar os senhores. Sendo o caso grave, pedimos providencias a quem competir parecendo prudente que desde já se exerça fiscalização mais ativa sobre esses navios.

As fugas marítimas foram relatadas em diversos momentos por autoridades e moradores da Ilha de Santa Catarina. Isso revela que a prática de se aliciar escravos para a fuga não era novidade quando veio à tona o caso do brigue Highland Mary of Sag Harbor. A fiscalização, conquanto recomendada pelas autoridades, era feita somente nos dois ancoradouros em frente ao centro da cidade, sendo que os ancoradouros da Praia de Fora e da Fortaleza de Santa Cruz eram usados de forma mais livre. 
O desfecho do caso envolvendo o Highland Mary of Sag Harbor não é de todo surpreendente: a embarcação conseguiu fugir da Ilha de Santa Catarina ilesa. Provavelmente, o capitão do barco recebeu informações de que estava sendo preparada uma expedição de busca e apreensão e zarpou levando consigo os sete escravos fugitivos e mais o crioulo Fructuoso, também fugitivo e que já fazia parte da tripulação há um bom tempo.

Não foram apenas os baleeiros estrangeiros que aceitaram escravos fugitivos. Há relatos de diversos casos de fuga em barcos menores, envolvidos na navegação de cabotagem (navegação costeira ou entre os portos do mesmo país). Não eram apenas os cativos da ilha e do litoral catarinense que utilizavam a rota marítima de fuga, ao que tudo indica, essa foi prática relativamente comum em boa parte do litoral brasileiro, especialmente a partir da segunda metade do século XIX. Isso pode ser observado pela publicação de anúncios de fuga de escravos de outros estados nos jornais de Desterro, ressaltando sempre que se o escravo desembarcasse em Santa Catarina, era necessário comunicar imediatamente seu dono para providências de busca e apreensão. $O$ jornal O Argos relatou um destes episódios no dia 12 de dezembro de 1856.

20:000 REIS de gratificação. Fugiu no dia 9 do corrente de bordo do brigue "Minerva" um crioulo marinheiro de nome Luiz, que terá de idade 19 a 20 anos, e foi escravo de Felippe José dos Passos; levou vestida roupa de serviço de bordo, de algodão azul, ou de riscado. É de estatura regular, bonita vista, retinto, ainda não mostra sinais de barba. Quem descobrir aonde ele se acha, ou apresentar ao seu senhor, receberá a gratificação supra. Desterro, 11 de Dezembro de 1856.

Os escravos tinham conhecimento de que podiam utilizar barcos para fugir e até ameaçavam seus senhores com tal possibilidade. Em vários anúncios de fuga, principalmente após a década de 1850, os senhores aludiam à intenção de fuga em barcos, geralmente americanos. Com o intuito de abandonar definitivamente o cativeiro ou simplesmente de mudar de vida, muitos escravos se arriscaram em navios de partida para outras localidades, longe de seus senhores, e onde dificilmente seriam reconhecidos. A possibilidade chegou ao conhecimento de muitos escravos que buscaram nesses navios seu passaporte para uma transformação 
142 nas suas vidas e para conquistar a liberdade. Os senhores, contudo, diretamente lesados com tais atos, expressavam sua revolta através de denúncias na polícia e de processos movidos contra os responsáveis pelo aliciamento ou simplesmente transporte de escravos a bordo de seus navios. Com isso, esperavam intimidar os responsáveis pelas embarcações, para que não admitissem fugitivos entre sua tripulação.

\section{Os últimos anos da escravidão, décadas de 1870 e 1880}

As regras que orientavam senhores e escravos sofreram mudanças durante todo o período escravista. O século XIX foi cenário de grandes conquistas em prol da liberdade, algumas, consequência de pressões diretas ou indiretas dos escravos, outras, da atuação de abolicionistas. Muitas pessoas não concordavam mais com os horrores da escravidão. Os jornais traziam notícias da libertação dos escravos em diferentes partes da América, e o Brasil adquiria a imagem de atrasado por não aderir completamente ao trabalho livre.

O fim do tráfico atlântico e a Lei do Ventre Livre, de 1871 limitaram o crescimento da população escrava e a Lei dos Sexagenários, de 1885, libertou apenas os escravos idosos. As leis chamadas de abolicionistas significaram interferência do Estado imperial nas relações escravistas, mas também prolongaram o domínio dos senhores sobre seus escravos. A forma como senhores, escravos e a população em geral percebiam as fugas foi se transformando, juntamente com o escravismo. Na Ilha de Santa Catarina, desde meados da década de 1870, o número de anúncios de fuga começa a diminuir, e a partir de 1885, os registros de fugas somem totalmente dos jornais de Desterro. Duas questões surgem a partir desta constatação: 1) os escravos não achavam mais que a fuga resolveria seus problemas? 2) os jornais que pararam de publicar anúncios de fuga por não concordarem mais com a escravidão? É bem provável que tenha sido um pouco das duas coisas. O movimento abolicionista ganhou força, especialmente nas cidades, na década de 1880. Membros de clubes abolicionistas se esforçavam para arrecadar fundos e comprar alforrias e divulgar a causa. Mas nem todas as pessoas que participavam desses clubes eram veementemente contra a escravidão: participar da causa abolicionista no período final da escravidão no Brasil era considerado 
"moderno". Assim, existiam pessoas mais preocupadas com a promoção da própria imagem do que com o fim da escravidão. Mas o motivo da adesão à causa abolicionista não era o mais importante para os escravos; para os que ainda permaneciam cativos ou para os que, mesmo livres, tinham amigos escravos, importava que, cada vez mais, a escravidão se constituía alvo de críticas, e que o dinheiro arrecadado pelos clubes abolicionistas, mesmo que não fosse muito, poderia representar a compra da liberdade para muitos escravos.

A mudança de comportamento em relação à escravidão pode ser exemplificada com o caso de João Minhoca. Segundo o jornal O Conservador do dia 11 de abril de 1885, o senhor João Minhoca, redator do jornal Regeneração, faltava com a verdade, pois afirmava ser abolicionista, mas havia publicado em seu jornal um anúncio de escravo fugitivo. $O$ jornal O Conservador também fez uma sátira a João Minhoca, aconselhando-o a buscar, pessoalmente, o fugitivo que seu jornal havia anunciado. O dono do escravo que mandou publicar o anúncio também foi alvo de censuras. Esse episódio evidencia um ganho para os escravos, pois quem estava sendo criticado não era o fugitivo, descrito como "pobre José". Depois das duras críticas do periódico $O$ Conservador, não foi encontrado mais nenhum anúncio de fuga nos jornais de Desterro. $O$ fato indica como as fugas de escravos eram vistas neste momento e também um possível motivo para o seu desaparecimento dos jornais: já não era bem-visto anunciar um fugitivo. A propagação da imagem da abolição como algo "civilizado", "nobre", e a sua assimilação por parte da população fez com que a exposição pública da escravidão, como ocorria nos anúncios de fuga, passasse a ser malvista. As mudanças sociais, mesmo que lentas, acabaram mostrando resultado. Muitas pessoas certamente foram a favor da escravidão, até o seu fim, e mesmo após a abolição, consideravam o fim do trabalho escravo um erro. Mas a sociedade havia mudado, especialmente graças à luta constante dos escravos em busca de melhores condições de vida, e tal forma de propriedade já não tinha como se sustentar por muito tempo.

O fato de os jornais pararem de publicar as fugas não significava que os escravos tenham deixado de fugir. Atitudes extremas, as fugas realmente tinham diminuído. Os escravos optavam por escapar do cativeiro quando não acreditavam mais que resolveriam determinada situação de outra forma. Já fizemos referência, anteriormente, às 
dificuldades da fuga, o que também contribuía para a sua diminuição. E o proprietário que pretendia libertar seus escravos começaria pelos que lhe eram mais fiéis e não pelos que lhe causavam transtornos. Um "bom escravo" teria mais chances de ganhar a confiança do senhor para, em troca de sua liberdade, assinar um contrato de trabalho. As fugas não representavam a melhor opção de barganha para os escravos na Ilha de Santa Catarina durante a última década do período escravista brasileiro.

\section{Considerações finais}

A fuga esteve presente durante todo o período escravista catarinense e brasileiro, mas não devemos considerar que teve sempre os mesmos objetivos. Os motivos quelevaram os escravos a escapar do cativeiro variaram com o tempo e de acordo com as suas experiências, esperanças e desejos para o futuro. Para os cativos recém-chegados às províncias brasileiras, fugir pode ter sido um ato de protesto, de rejeição à nova forma de vida que lhes era imposta. Por sua vez, uma fuga de curto período poderia ser uma forma de o escravo avisar ao seu senhor que ele estava disposto a realmente fugir, caso não ocorressem certas mudanças no cativeiro. Os senhores conheciam os riscos de desrespeitar totalmente a vontade do escravo e, por isso, em alguns momentos, recuavam e atendiam a um ou outro anseio dos cativos, com o objetivo de evitar uma revolta, um boicote na produção, uma fuga etc. Os escravos certamente lutariam por "conquistas" no cativeiro, como mobilidade, acesso a roças, pequenas recompensas monetárias, direito de morar com a família etc. Aos senhores, cabia avaliar o momento certo de conceder os "direitos", a fim de manter sua autoridade e evitar as diversas formas de rebeldia e protestos.

Quando o jogo de forças entre senhores e escravos era rompido ocorriam revoltas, fugas, formação de quilombos. Estes existiam em quase todos os locais onde houve escravidão no Brasil, e eram uma alternativa para o cativo que desejava a fuga definitiva ou, pelo menos, mais longa. Em outros casos, os escravos conseguiam refúgio em casas de amigos ou pessoas com as quais estabeleciam um acordo de trabalho, de dependência. Outro caminho de fuga encontrado na Ilha de Santa Catarina, determinado principalmente pelas condições geográficas, foi o mar, por meio das embarcações. 


\section{ARQUIVO DO ESTADO DE SANTA CATARINA}

Ofícios dos Juízes de Fora para o Presidente da Província

Ofício de 19 de agosto de 1822.

Registro das Correspondências do Presidente da Província para os Juizes

Ofício de 28 de janeiro de 1842;

Ofício de 2 de agosto de 1842.

Ofícios do Chefe de Policia para o Presidente da Província

Ofício de 9 de agosto de 1842;

Ofício de 12 de maio de 1868;

Ofício de 22 de junho de 1866.

Registro da Correspondência do Presidente da Província aos Juízes

Ofício de 5 de fevereiro de 1842.

ARQUIVO HISTÓRICO MUNICIPAL DE FLORIANÓPOLIS

Registro de Provisões, Desterro, 1751. Livros Históricos, n. 318 (153 B.C.), p. 12 e 13.

BIBLIOTECA NACIONAL (RIO DE JANEIRO)

Mapa de população, 1820. I-31, 29, 18 n. 9.

BIBLIOTECA PÚBLICA DO ESTADO DE SANTA CATARINA

O Novo Íris

A Província

O Despertador

O Conservador

O Argos

\section{Referências}

AMANTINO, Márcia S. Sobre quilombos do sudeste brasileiro nos séculos XVIII e XIX. In: FLORENTINO, Manolo; MACHADO, Cacilda (Org.). Ensaios sobre a escravidão. Belo Horizonte: Editora da UFMG, 2003. v. 1. p. 241.

CONRAD, Robert. Os últimos anos da escravatura no Brasil: 1850 - 1888. Rio de Janeiro: Civilização Brasileira, 1978.

FARIAS, Joice. A Lagoa da Conceição também é dos pretos! Experiências dos grupos populares no leste da Ilha de Santa Catarina (1870-1880). 2003. Dissertação 
(Mestrado em História) - Universidade Federal Fluminense. Rio de Janeiro, 2003.

FLORENTINO, Manolo. Fugas e Quilombos nas Américas: uma reavaliação. Conferência proferida no X ENCONTRO Estadual de História - Trabalho/ Cultura e Poder/3a Reunião Nacional do GT Estudos de Gênero/II Jornada Nacional de História do Trabalho, Florianópolis, 30 de agosto de 2004.

GOMES, Flavio dos Santos. A hidra e os pântanos: mocambos, quilombos e comunidades de fugitivos no Brasil (século XVII - XIX). São Paulo: UNESP/ Polis, 2005.

LARA, Silvia Hunold. Campos da Violência: escravos e senhores na Capitania do Rio de Janeiro, 1750-1808. Rio de Janeiro: Paz e Terra, 1988.

. Trabalhadores escravos. Trabalhadores, Campinas: Fundo de Assistência à Cultura, n. 1, 1989.

MENDONÇA, Joseli M. Nunes. Entre as mãos e os anéis: a lei dos sexagenários e os caminhos da abolição no Brasil. Campinas: Unicamp, 1999.

PENNA, Clemente Gentil, Vivendo sobre si: estratégias de liberdade de africanos e afrodescendentes na Ilha de Santa Catarina (1870-1888). 2001. Monografia (Graduação em História) - Universidade do Estado de Santa Catarina - UDESC. Florianópolis, 2001.

PIAZZA, Walter F. A escravidão negra numa província periférica. Florianópolis: Garapuvu, 1999.

SILVA, Eduardo. Fugas, revoltas e quilombos: os limites da negociação. In: REIS, João J.; SILVA, Eduardo. Negociação e conflito: a resistência negra no Brasil escravista. São Paulo: Cia das Letras, 1989.

SLENES, Robert. Na senzala uma flor: esperança e recordações na formação da família escrava. Brasil Sudeste, século XIX. Rio de Janeiro: Nova Fronteira, 1999.

ZIMMERMANN, Fernanda; MAMIGONIAN, Beatriz Gallotti. Africanos entre açorianos: tráfico atlântico e trabalho escravo no Ribeirão da Ilha na primeira metade do século XIX. In: RELATÓRIO PIBIC. Florianópolis: Departamento de História/CFH/UFSC, 2003/2004. 


\section{|| Capítulo 7 ||}

\section{Africanos e descendentes na história do primeiro mercado público de Desterro}

Fabiane Popinigis

Em um dia de abril de 1860, Maria Mina foi ao cartório do 2ํOficio do Desterro, no centro da cidade, juntamente com Luis de Santa Anna Carpes, seu proprietário, para fazer o registro de sua alforria. A liberdade não era um presente, embora ela provavelmente o merecesse, mas o resultado de seus esforços. Sua alforria foi onerosa, isto é, paga, mas não condicional: ela estava livre para "usufruir de sua liberdade como se de ventre livre nascesse". ${ }^{1}$ Tinha emprestado o dinheiro do Capitão Clemente Antônio Gonçalves, mas não assinou com ele contrato de locação de serviços, pelo qual se comprometeria a servi-lo. De onde tirava Maria seu sustento, podendo garantir o pagamento de seu próprio valor, $800 \$ 000$ (oitocentos mil réis), ao Capitão Gonçalves?

Ela era uma das muitas quitandeiras, escravas e ex-escravas de Desterro, e pode ser que tenha andado pelas ruas da cidade vendendo produtos de quitanda de porta em porta, como faziam tantas outras naquela época. O que de fato sabemos é que, em algum momento, Maria Mina passou a trabalhar na Praça do Mercado, para o que pagou o devido aluguel de um vão, que dividia com uma tal Thereza.

O mercado em que Maria, Thereza e muitas outras vendiam seus produtos de quitanda para garantir seu sustento, em 1869, era o primeiro Mercado Público de Desterro, inaugurado em janeiro de 1851, após longa

1 Este trabalho resulta de pesquisa financiada pelo CNPq, através de bolsa de pós-doutorado. CARTÓRIO DO 1 TABELIONATO DE NOTAS DE FLORIANÓPOLIS. Livro $\mathrm{n}$ 을 22 do 2 o Ofício do Desterro, 1859. Escritura de liberdade que Luis de Santa Anna Carpes passa à sua escrava Maria Mina. 
negociação entre alguns de seus habitantes, a presidência da província de Santa Catarina e a Câmara Municipal. O Mercado ficava na Praça da Matriz (em referência à Igreja da Matriz), que, após a Proclamação da República, passou a chamar-se Praça XV de Novembro. Não foi fácil chegar à decisão de construí-lo, assim como difícil foi encontrar um consenso a respeito do local. Contaremos aqui um pouco dessa história a partir da presença africana nas redes de distribuição do comércio ambulante e de varejo e sua importância para a organização das relações de trabalho e sociabilidade na Praça do Mercado.

\section{Os planos de "aformoseamento" para Desterro e o Largo da Matriz}

Desde o início da década de 1830, nutria-se a polêmica a respeito da retirada ou da permanência das barraquinhas de venda de gêneros alimentícios no Largo da Matriz. Nos seus arredores ficavam as lojas de importantes comerciantes da cidade, que não estavam interessados em afastar dali os atrativos que garantiam a circulação do público. A polêmica varou a década e mobilizou os "homens bons" - como eram chamados os homens de posses e cargos políticos - de Desterro em torno de solidariedades que se revelariam incipientes divergências políticas. As barraquinhas chegaram a ser desenganadas em 1834, mas a lei não foi cumprida, o que nos dá uma ideia da predominância política do grupo barraquista nos âmbitos de decisão. ${ }^{2}$ As quitandeiras provavelmente estendiam suas tendas e panos naquele mesmo lugar do Largo, desde o final do século XVIII, vendendo legumes, frutas, doces, peixe seco e comida preparada, de modo semelhante ao que ocorria em outras grandes cidades da América portuguesa com presença significativa de africanos. Os produtos repousavam nas esteiras, e as mulheres improvisavam tendas para proteger a si e suas mercadorias do sol.

Este era um comércio importante em Desterro, já que, segundo o historiador Oswaldo Cabral, o movimento das lojas importadoras era muito superior ao das 44 casas de secos e molhados existentes em 1796. De onde podemos inferir que grande parte dos produtos que chegavam ao

$2 \quad$ CABRAL, 1971, p. 83. 
porto era vendida em lugares diversos dos estabelecimentos comerciais existentes. Prova disso é o grande número de pessoas, com predominância de mulheres, pagando impostos de pombeiro e mascate, isto é, licenças para o comércio ambulante.

A luta contra o açambarcamento e os esforços em taxar os principais produtos alimentícios para a população vinha desde este tempo. A alimentação básica dos trabalhadores pobres constituía-se de farinha de mandioca e peixe. Havia também o milho, o arroz, o feijão e uma grande diversidade de legumes e frutas. A farinha de mandioca, principal produto da Ilha, era motivo de disputa entre as autoridades, os comerciantes e os populares. Às vezes, era exportada levando em conta as necessidades das províncias do norte mais do que as dos habitantes locais. Também podia ser requisitada para as tropas no Rio Grande do Sul e, finalmente, quando o Vice-Rei ordenava sua compra por preço estipulado para vendê-la ao povo por preços acessíveis, os comerciantes, insatisfeitos, ameaçavam guardá-la em seus armazéns. Em 1844, por exemplo, a Presidência da Província determinou e a Câmara fez cumprir ordem, segundo a qual as embarcações deveriam aportar na praia e os produtores vender a farinha diretamente aos consumidores. Quanto ao peixe, ao pombeiro não era admitida a venda, e era por isso vendido diretamente das canoas, em esteiras e balaios, pelo próprio pescador ou seus escravos. Já em 1791 determinara-se a construção de duas bancas de peixe, além da venda na praia, em frente à própria Praça aonde chegavam as canoas.

A Câmara fiscalizava isso tudo. Ficava a cargo do almotacé controlar a qualidade dos gêneros e sua apresentação no mercado, evitar monopólio, açambarcamento e preços "imorais". Ao conjunto dessas práticas e mais a questão sanitária e de construção correspondia o direito de almotaçaria na América Portuguesa. Em Desterro, os almotacés observavam o corte da carne e sua venda ao preço estipulado, inclusive em pequenas porções de uma libra, contra a resistência dos carniceiros, que preferiam vender a carne em grandes lotes.

$\mathrm{O}$ direito de almotaçaria, relacionado ao aparecimento e à organização das cidades, presente em todo o Império Português, apoiavase em antigas prerrogativas tradicionais, em torno das quais os protestos das pessoas geralmente se organizavam, reivindicando algo como uma “justiça de mercado". Como explica Magnus Pereira, a falta de alimento 
endêmica não era entendida pela população como um mero problema de escassez de gêneros e, portanto, seus ciclos não podem ser entendidos apenas como contingências econômicas: "A fome era sintoma de um desequilibro moral, uma ruptura do pacto da almotaçaria. O grito contra a fome, quase sempre real, pois se ela era endêmica, dava partida a lutas contra a apropriação de alimentos escassos pelos poderosos, mas também contra o excesso de impostos, usurpação da terra, do poder local ou da própria Coroa"... Em suma, partia-se do princípio que lucrar com a fome alheia era amoral.

No decorrer do século XIX, essas atribuições de regulamentação e fiscalização passaram a ser função da Câmara Municipal e seus fiscais. Mas a ideia do direito dos pobres ao acesso aos alimentos básicos, a obrigação do produtor de vender na praça do mercado em pequenas porções, dando oportunidade a todos de comprarem a "preço justo", e a preocupação com a qualidade do produto (que a carne não estivesse podre ou pesteada, ou que a farinha da qual se houvesse extraído a goma não fosse vendida), continuariam presentes nas posturas, sendo objeto de fiscalização. A Constituição de 1824 reconhecia as Câmaras Municipais como órgãos de autoridade local, e em 1828, regulou-se o seu funcionamento, quando elas passaram a ser subordinadas ao governo das províncias. Era função das Câmaras zelar pelo cumprimento das posturas, e para isso, contava com fiscais. Grande parte da renda da Câmara vinha dos contratos do direito de venda de alguns gêneros essenciais, como, por exemplo, a carne; dos impostos sobre o abate de animais e a venda do produto; e das multas por infração de posturas. Isso, por vezes, significou que algumas propostas eram mais interessantes para os cofres da Câmara do que para o bolso dos pobres, momentos em que o Presidente da Província podia interferir, e o fazia.

O produto mais exposto às ações de açambarcamento e exploração era a carne verde (a carne fresca, em oposição ao charque). Desde a segunda metade do século XVIII, as condições da concessão do açougue da Vila para o fornecimento de carne à população previam o pagamento de imposto à Câmara por cabeça de gado abatido e a fixação do preço de venda para a população pela libra de peso. Assim como no caso da farinha, os poderes públicos procuravam impor medidas para o controle

3 PEREIRA, 2001, p. 365-395. 
do preço e da qualidade da carne que chegava aos habitantes. As posturas e editais em geral procuravam evitar não só a especulação sobre o preço daquele produto, a entrada clandestina de gado na Província e a venda sem autorização burlando o pagamento de impostos, como também a venda da carne podre, estragada, ou pesteada. Muito disso chegou até nós através dos ofícios trocados entre a Câmara Municipal e a presidência da Província, que frequentemente se desentendiam sobre o assunto - esta última chamando a atenção da primeira por priorizar as vantagens monetárias que o contratante oferecia à própria Câmara, em vez dos benefícios oferecidos ao público. Afinal, era dos pagamentos advindos dos contratos e dos impostos que a Câmara tirava grande parte de suas rendas.

Nesse espírito, a partir da década de 1830, a fiscalização da Câmara previa multa de quatro mil réis para quem tentasse vender "gêneros comestíveis e líquidos corruptos", punia os que saíssem a vender os produtos antes das nove horas da manhã e os atravessadores que fizessem compras antes do mesmo horário para depois revender a mercadoria encarecida. Esses eram multados em 2.000 réis. Como mais um passo para controlar o fornecimento de carne, em 1840, a Presidência da Província começaria um plano sobre a construção de um matadouro, que terminou por ser construído perto do forte de Sant'Ana, junto ao cemitério. Não por acaso, no mesmo período, davam-se as primeiras tentativas de levar a cabo um projeto para o Mercado Público, que fazia parte de um plano mais geral de regular a venda de gêneros alimentícios e os impostos que isso rendia. Em 1838, dois engenheiros apresentaram um projeto para a construção de uma Praça do Mercado junto ao mar, entre a Rua do Livramento e a do Ouvidor (atuais Trajano e Deodoro, respectivamente), mas o projeto não foi levado adiante. Até o ano seguinte, ninguém se apresentou após a abertura dos editais para a construção da dita Praça do Mercado.

Em 1845, as barraquinhas foram transferidas da Praça para as proximidades da Ponte do Vinagre e do Forte de Santa Bárbara. O motivo era a visita do Imperador D. Pedro II e da Imperatriz Dona Thereza Christina à cidade, em passagem para a Província vizinha de São Pedro do Rio Grande do Sul. Desembarcaram em outubro de 1845 e ficariam cinco dias, que se estenderam a 27, durante os quais visitaram diversos locais na Província, deixando as autoridades provinciais e municipais 
em polvorosa. Em fevereiro de 1846, após a partida da família real à Corte, voltaram à carga os "barraquistas", querendo que o comércio de gêneros retornasse ao local onde antes estava, ou seja, a Praça da Matriz, contrariando grupo dos "vinagristas" (assim chamados porque queriam que a feira permanecesse nas proximidades da Ponte do Vinagre).

Em maio de 1846, a Assembleia Provincial aprovou lei que ordenava a construção do mercado no local mais conveniente, sem, contudo, determiná-lo, o que acirrou a discussão. Irritado com a pendenga, o presidente da província decretou que todos pudessem vender seus gêneros livremente, em qualquer local, exceto... na Praça do Palácio. Como se pode imaginar, foi obrigado a voltar atrás dias depois, tamanha foi a grita geral. Em 1847, a Câmara pedia ao governo provincial que aprovasse a construção de três barracões na dita praça. O então Presidente da Província de Santa Catarina, Antero Ferreira de Brito, opôs-se terminantemente ao projeto. A Câmara voltou a reclamar do veto, mas o presidente fincou pé, explicando que o considerava de mau gosto e oposto ao que queria fazer: construir a Alfândega, cais e rampas ao longo da praia, para facilitar a chegada dos passageiros e mercadorias e embelezar a linha do mar. Insinuou, finalmente, a ideia da construção de um mercado: "Façamos a rampa, com que já me vou occupar, depois do que não duvidarei que alli então se construa uma praça de mercado, porém que seja segundo o plano que a Presidência apresentar, e que será correspondente à belleza da praça. A Câmara Municipal há de conformar-se com isso". ${ }^{4} \mathrm{O}$ tom era imperativo, e deixava claro que se o Governo da Província tinha de arcar com as despesas da construção, havia também de fazer-lhe o plano, que deveria ser seguido à risca pela municipalidade. Desta feita, o Presidente escreveu longa explicação, advertindo a Assembleia Provincial sobre a inconveniência de se erguerem os três barracões que os vereadores e o presidente da Câmara Municipal haviam solicitado para a venda de pescado, farinha, hortaliças, grãos e para a carne verde. Argumentava que aquilo daria má ideia sobre "nosso bom gosto", relembrando a recente existência de uma banca de peixe na mesma praça. Esta lhe incomodara a vista e continuava a lhe atazanar a memória: "o peixe fresco de mistura

4 Falla que o presidente da província de Santa Catharina, o marechal de campo Antero José Ferreira de Brito, dirigio à Assembleia Legislativa da mesma província no acto da abertura de sua sessão ordinaria em o 1o de março de 1847. Cidade do Desterro, Typ. Provincial, 1847, p. 9-12. 
com a carne, e tudo calcado aos pés dos pretos e pretas quitandeiras". ${ }^{5}$ Assim, Antero de Brito pretendia evitar que se incorresse novamente no erro, estragando a vista daquela praça que era por ele tão bem considerada, e da qual ele tanto se havia ocupado, tratando da reforma da Igreja, da criação de dois pequenos jardins, da plantação de árvores e da construção do edifício público da Tesouraria. Também desejava que, no "edifício a que impropriamente se chamava Palácio" - e que ele estava cuidando de embelezar e aumentar -, pudesse futuramente reunir-se a Assembleia Provincial.

Antero Ferreira de Brito havia feito carreira militar e exercido postos de comando no executivo da Corte. Ocupou o cargo de Presidente da Província de Santa Catarina entre 1840 e 1849 e subordinou a ideia da construção do Mercado ao seu audacioso plano de intervenção no espaço urbano da pequena Desterro. Entre as intervenções sugeridas, a construção de um cais em frente à Praça do Palácio, de murada ao longo de toda a linha do litoral, com rampas, e a execução de um aterro próximo à rua do Menino Deus. Obcecado pelo "aformoseamento" da Capital da Província, talvez bem mais do que com seu saneamento - bem ao espírito da época -, contrapôs-se às intenções da Câmara Municipal de construir barracões na Praça da Matriz, afirmando empenhar-se em propiciar as condições para a construção de um Mercado Público que atendesse às necessidades de compra e venda da população, mas que também embelezasse o local. Desenvolveu-se a partir desta questão acirrada disputa dentro da própria Câmara, visando à liderança política no pleito, em geral, descrita pelos historiadores como o início da história dos partidos na cidade.

Meses depois, em outubro de 1847, Antero Ferreira de Brito continuava irritado com a indecisão dos vereadores da Câmara Municipal; escreveu que, tendo juntado grande quantidade de pedras e aterro no local a ser construída a rampa ao longo da praia da Praça da Matriz, nada mais seria feito até que a Câmara entrasse em consenso. Bem se vê que ele tentou liberar a Praça daquele amontoado de todo o tipo de gente, dos cheiros e consistências do pescado, da carne e dos restos que eram jogados ao mar. Se nisso falhou, seguiu com plano do Mercado: antes que deixasse o cargo, em dezembro de 1848, a Assembleia Provincial aprovou uma lei autorizando, com recursos da Província, o financiamento da edificação

5 Ibidem. 
154 do dito Mercado, que seria posteriormente passado à administração municipal.

\section{Finalmente pronto}

O projeto para a construção do prédio do Mercado ficou a cargo do engenheiro João de Souza Mello e Alvim. Em março do ano seguinte Severo Amorim do Valle, que então ocupava o cargo de Presidente da Província, informava, animado, sobre o avanço da construção e a necessidade de mais verbas para concluí-la. Antonio Ferreira Pinto, seu sucessor, deixou documentado o desgosto pela escolha do local, através de seu tom irônico: "[...] esse edifício no lugar em que se acha collocado, na Praça Principal desta Capital, He um epigrama à civilização, e ao bom gosto". ${ }^{6}$ Quem certamente estava feliz da vida era João Pinto da Luz, político, armador e negociante com loja de ferragens na Rua Augusta que mais tarde passaria a levar o seu nome, localizada ao lado da praça - e desde sempre interessado na construção do Mercado naquele local. A ele coube a administração da obra. Foi assim que, para o desgosto de alguns, o regozijo de outros e a desconfiança de muitos, a obra foi lentamente adiante.

Ao findar o ano de 1850, estava pronto o prédio da Praça de Mercado, no alinhamento da Rua do Príncipe (atual Conselheiro Mafra), na parte de baixo do Largo da Matriz, junto ao mar. Ao final, seu custo subiu a 12:297\$230 réis, três vezes mais que o orçamento inicial. A renda do Mercado ficou hipotecada até 1853, em função do pagamento da dívida. Foi oficialmente inaugurada em janeiro de 1851 , quando o presidente da província, João José Coutinho, passou as chaves ao presidente da Câmara Municipal, Clemente Antônio Gonçalves.

O historiador Oswaldo Cabral define o aspecto externo do Mercado como "[...] um bloco de quatro faces, retangular com uma porta em cada lado, com quatro pares de olhos de boi nas faces mais externas, e dois nas menores. Os cantos eram ornados com um jarrão de alvenaria e a platibanda do lado que fazia frente para a praça era enfeitada com um tímpano bastante simples sobre a porta principal. O telhado era baixo,

6 Relatório em que o Exmo. Sr. Dr. entregou a presidência da província de Santa Catarina ao exmo. Sr. Dr. Severo Amorim do Valle, 3Vice-presidente, em 30 de novembro de 1849, p.16-17. 
achatado, de telhas goivas". ${ }^{7}$ O Mercado era, portanto, um prédio retangular térreo, com portas nos quatro lados, que davam acesso ao espaço no qual os vendedores ocupavam "casinhas" nos nichos cobertos, ou "vãos" - os espaços junto aos pilares. No centro, havia um pátio descoberto. Eram 12 casinhas, com portas, janela e paredes divisórias entre elas, mais quatro bancas de carne e as de peixe. As bancas de carne tinham balcão e mesas de picar, com grades de madeira e piso de tijolos, quatro ganchos fortes para pendurar a carne, seis balanças de 15 quilos e uma de 58,8 quilos. As bancas e o gradeamento eram pintados a óleo. No pátio central, existia também um poço para uso dos negociantes e do público. Nesse pátio central, os lavradores depositavam suas mercadorias - com exceção da carne verde e do peixe, ou lenha e carvão - para vendê-las ao público em pequenas medidas, até nove horas da manhã. Depois desse horário, os pombeiros poderiam arrematá-las. Era permitido aos lavradores que ali ficassem com o que restara para vender até as $14 \mathrm{~h}$, quando o Guarda da Praça, encarregado de manter a ordem, os retirava. Eram designados pombeiros aqueles que compravam mercadorias diretamente dos produtores e depois passavam a mascatear, revendendo-as pelas ruas da cidade ou de porta em porta, àqueles que, por alguma razão, não fossem adquiri-las no Mercado. Para exercer a função, os pombeiros pagavam imposto à administração municipal. A postura que determinava o horário mínimo para o repouso dos gêneros visava permitir a todos o acesso aos produtos sem o acréscimo dos intermediários. Entretanto, o pátio não oferecia espaço suficiente para todos os lavradores, e muitos continuavam, junto com seus víveres, legumes, ovos e hortaliças, à mercê do sol e da chuva. Embora isso tenha sido constatado e reclamado através dos jornais, parece que era algo já esperado, pois um dos artigos do regulamento do Mercado definia que o Guarda permitisse aos que tivessem gêneros perecíveis ocupar um lugar na varanda.

O lugar que seria ocupado por mulheres como Anna Mina, Thomázia Cabral, Maria do Sacramento, Josefa Caçange, Maria Cardozo e Luiza Cabinda, Joanna Prates ("preta forra") e Joana Rosa, na década de 1850, e por Maria Mina (liberta), Thereza, Maria Rosa, Faustina e muitas outras quitandeiras, na década de 1960, era um dos vãos entre as colunas do Mercado, localizados entre o pátio central e a varanda. Cada

7 Cf. CABRAL, 1971, p. 78-79. 
um desses vãos era dividido em dois espaços, e cada um desses "espaços de quitanda" poderia ser ocupado por duas pessoas. Pagava-se $1 \$ 200$ réis mensais pelo aluguel, e os idealizadores certamente contavam com a presença das escravas quitandeiras ali, considerando o baixo preço e a possibilidade de dividir o aluguel. O regulamento era bastante claro nesse sentido: enquanto "as casas só poderão ser alugadas a pessoas livres", os lugares de quitanda "poderão ser alugados a pessoas livres, e a escravos, com licença por escripto de seus senhores", o que demonstra a frequência e o costume destes arranjos de trabalho.

\section{Redes de distribuição e economia interna}

Em 1855, Desterro tinha 5.611 habitantes, dos quais 1.436 (25\%) eram escravos. ${ }^{8}$ No Mercado, os habitantes do pequeno núcleo urbano da primeira metade do século XIX abasteciam-se, punham em dia suas conversas, faziam seus negócios. Havia muito que as canoas atracavam na praia em frente à Praça. Lavradores das demais freguesias da Ilha vinham trazer seus produtos, como provavelmente fizera o "preto liberto Lourenço Carlos Cunha", que possuía 132 metros de terra situados de frente para o mar, na Caieira da Barra do Sul. Provavelmente sem herdeiros, em 1882, lavrou documento doando a propriedade e o que havia nela a uma mulher livre e seus quatro filhos, não sem garantir que ele mesmo tivesse o usufruto do lugar e de sua estrutura enquanto vivesse. Ali havia uma chácara, um moinho de milho e duas canoas, o que certamente dava a Lourenço muitas possibilidades de inserção na economia da Ilha e de garantir sua sobrevivência e a dos seus através da venda dos gêneros produzidos na dita chácara na praça de Mercado de Desterro, por ele mesmo ou por suas beneficiárias.

Afinal, era ali que escravos e escravas faziam a vida, ao lado de homens e mulheres libertos e livres, fossem caixeiros, pombeiros, quitandeiras ou os lavradores que vinham trazer seus produtos. Em diversas regiões e épocas, a praça do mercado era, além da troca e do comércio, o lugar onde se travavam relações sociais de todo tipo, com grande diversidade de atores sociais.

\footnotetext{
8 Mappa aproximado da População da Província de Santa Catharina. Relatório do Presidente da Província, João José Coutinho, apresentado em março de 1855. p. 36.
} 
Mas às tentativas de regular suas redes de sociabilidade e suas possibilidades econômicas, os escravos e libertos resistiam. Assim, como o Regulamento do Mercado proibia "andarem dentro da Praça pretos de ganho e mendigos" e determinava 24 horas de cadeia aos que desobedecessem a advertência do Guarda do Mercado, fora dele, nos seus arredores, as negras continuavam a fazer comida para vender, fritando peixe e cozinhando mocotó. Também continuavam estendendo suas esteiras para a venda de produtos, ainda que as posturas procurassem restringi-la a lugares específicos, como o próprio Mercado, sujeitos a controle e taxação. $\mathrm{O}$ fato de editais e posturas estipulando multas para vários tipos de burla a essas determinações continuarem a ser publicados ao longo da segunda metade do século XIX evidencia a frequência com que ocorriam.

Apesar das recorrentes tentativas de regulamentação e repressão, tão difícil - ou mais - quanto controlar os açambarcadores e exploradores do povo, era dar conta dos negros de ganho, pretos e pretas quitandeiras e de tabuleiro que perambulavam pela cidade vendendo vários tipos de alimento, desde frutas frescas e doces até comida pronta.

A preta liberta Ana da Costa Pereira pagava imposto mensal de $6 \$ 400$ réis sobre mascates, em 1854 . Nesse mesmo ano, as pombeiras Luiza Cabinda, Anna Mina, Zeferida Calabá (corruptela de Calabar), Josefa Caçange e as pretas Esperança Cabinda, escrava de João Lopes Falcão, e Margarida pagavam imposto relacionado ao ato de comerciar, depositando nos cofres da Câmara Municipal, cada uma, a soma mensal de $3 \$ 200$ réis. $^{10}$

À reconhecida liberdade de ir e vir dessas mulheres no ambiente urbano, já muito reafirmada pela historiografia, os poderes públicos procuravam impor limitações. O artigo 41 do Código de Posturas proibia escravos com quitanda de andarem nas ruas ou permanecerem nas praças após o toque de recolher, ficando sujeito o recalcitrante à multa de mil réis ou 24 horas de prisão, se seu senhor não pagasse a multa. A determinação

9 ARQUIVO PÚBLICO DO ESTADO DE SANTA CATARINA (APESC). Ofícios da Câmara Municipal à Presidência da Província, 21/12/1850. Regulamento do Mercado Público, art. 52.

10 Todos esses "sobrenomes" eram referências às diferentes "nações" africanas, denominadas a partir das regiões de origem do tráfico de escravos. O sobrenome da Costa designava, de forma geral, a procedência africana. 
era semelhante àquela feita no artigo 35 do Código de Posturas, segundo o qual "vadios, escravos" não poderiam permanecer nas vendas, tabernas ou casas de quitanda mais do que o tempo necessário para comprar e vender. Proibia-se também ao vendeiro consentir ajuntamentos de escravos, toques, danças e vozerios. O art. 38 do dito código proibia "os ajuntamentos de escravos, ou libertos para formarem batuques; bem como os que tiverem por objectos os supostos reinados africanos, que, por festas, costumão fazer". ${ }^{11}$

Se, por um lado, alguns senhores consideravam salutar permitir festas para distrair e contentar os escravos, pensando com isso minorar o risco de rebelião, os dias festivos podiam também encobrir planos de fuga individuais ou ações coletivas. As autoridades certamente estavam cientes da situação vivida na Corte, em Salvador e em outras cidades do Império, nas quais escravos e libertos, africanos e crioulos, se reuniam em casas particulares, comerciais ou "de quitanda" - onde além de comer, realizar festas e atividades religiosas, podiam esconder escravos fugidos ou planejar insurreições. Em 1850, menos de dois meses depois da ocorrência de um grande "batuque", motivo de disputa entre o subdelegado e o fiscal, a Câmara Municipal de Desterro ordenava, em ofício enviado ao mesmo chefe de polícia, Severo Amorim do Valle, o "exato cumprimento" do toque de noite para o horário de fechamento das casas comerciais, temendo os focos de ajuntamento de africanos e crioulos, trabalhadores escravos e livres.

\section{Esforços de regulamentação e hierarquias do mercado}

Além dos que tiravam seu sustento das vendas do Mercado, mulheres e homens negros, livres, libertos ou escravos ao ganho misturavam-se a trabalhadores livres pobres, fazendo compras para si ou seus proprietários e patrões. Aos escravos e escravas só era permitido frequentar a Praça do Mercado se estivessem a serviço de patrões e patroas. Nesse caso, que fizessem rapidamente as compras: "não poderão demorar-se por mais tempo que o necessário para effectuar-las. O Guarda do Mercado, ou o 11 ARQUIVO HISTÓRICO MUNICIPAL DE FLORIANÓPOLIS (AHMF). Código de Posturas da Câmara
Municipal de Desterro (1845), Art. 38. 
Fiscal logo que observarem que elles alli se conservão sem intenção de comprar os farão sahir". ${ }^{12}$

Os escravos que trabalhavam no Mercado com respectiva licença dos proprietários não podiam nele pernoitar, condição aberta a outros, como aos locatários das casinhas (pessoas livres) e suas famílias. A permissão também se estendia "aos donos, consignatários, caixeiros de carne e peixe todas as vezes que a hora de fechar-se o Mercado ainda tenhão porção de qualquer d'esses gêneros nas bancas para venderem no dia seguinte". Esclarece-se também que nenhum quitandeiro ou quitandeira poderia pernoitar na Praça. Além desses, mais artigos destinam-se a tentar restringir a presença dos negros e negras na Praça do Mercado, inclusive proibindo música, jogos e danças, ou "qualquer outro divertimento". ${ }^{13}$

Sobre o movimento de exclusão do qual eram objeto os escravos e libertos e de sua determinação em permanecer no centro do processo de produção e distribuição de gêneros em Desterro, o caso de Joanna Prates pode ser revelador. Em 1854, apenas três anos após a inauguração do Mercado, Joanna pagara imposto de quitandeira, dividindo um intervalo de coluna na Praça do Mercado com Joana Rosa. Até aí, nada de extraordinário, ela estava acompanhada de muitas outras na mesma condição. Mas no ano seguinte, de agosto de 1855 a julho de 1856, a dita "preta forra" Joanna foi mais longe e alugou uma casinha na Praça do Mercado, em seu próprio nome. Como não sabia escrever, um tal Jacintho Francisco assinou o contrato por ela em agosto, repetindo o ato em janeiro do ano seguinte e alugando por mais seis meses a casinha $\mathrm{n}^{\circ} 3$ pelo mesmo preço de $6 \$ 600$ réis. O contrato semestral era feito através de leilão, por isso, os preços de aluguel a serem pagos pelos contratantes diferiam.

É significativo que Joanna tenha sido a locatária que mais caro pagou, dentre o grupo de nove pessoas que alugaram as casinhas do Mercado, quando renovou o contrato no primeiro semestre de 1856 . Além de ser a única ex-escrava, provavelmente africana, a constar nos contratos, era também era a única mulher. Desta vez, os preços do aluguel mensal variaram entre $5 \$ 000$ e $6 \$ 600$ réis, tendo ela sido a única a pagar o preço máximo para aquele período. Entretanto, a partir de junho de 1856, Joanna não mais aparece na lista de pagamento, e desta feita

12 APESC. Regulamento do Mercado Público, Art. 53.

13 Ibidem, Art. 51. 
todos os locatários pagaram os mesmos 5 mil réis pelo aluguel mensal de suas respectivas casinhas. Não sabemos o motivo pelo qual Joanna não renovou seu contrato, mas podemos especular. Houve uma desconfiança inicial em relação ao Mercado, e poucas casinhas foram alugadas logo após a inauguração. Em suma, como poucos se dispuseram a alugá-las, é provável que isso tenha facilitado o acesso de Joanna a uma das ditas casinhas. Inicialmente, subiram o preço do aluguel; Joana não se fez de rogada e pagou mais do que todos os outros para ter seu negócio no Mercado. Mas assim que a novidade se mostrou viável e agregadora do comércio local, desaparecendo a desconfiança e o estranhamento iniciais, os administradores provavelmente se esforçaram para substituí-la, talvez cedendo a pressões dos outros negociantes que se recusavam a aceitála em posição de igualdade. Após um ano, Joanna - a única mulher a alugar uma casinha em seu nome durante todo o período de existência do Primeiro Mercado Público de Desterro - desistiu ou foi forçada a sair, pois não renovou o contrato. O lugar de escravos e libertos, até o final do século XIX, seria o comércio de rua ou os vãos entre as colunas do Mercado lugares esses que eram foco de reiteradas tentativas de controle por parte dos poderes públicos.

Não havia, porém, mecanismo legal que impedisse Joanna de alugar a dita casinha, pois a proibição do Regulamento do Mercado não se referia aos libertos, mas aos escravos. Da mesma forma, o artigo 128 do Código de Posturas de Desterro, de 1845, proibia às pessoas de condição escrava ocupar a posição de caixeiro em qualquer casa comercial. No Mercado, aos escravos também era interdito vender carne ou pescado, a não ser que estivessem diretamente subordinados aos próprios "carniceiros" ou pescadores, como explica um dos artigos do regulamento: "só poderão ser vendidos pelos próprios carniceiros, pescadores, dizimeiros, seus consignatários ou caixeiros sendo pessoas livres, e os escravos dos próprios pescadores ou carniceiros". ${ }^{14}$

O pescado e, sobretudo, a carne verde, tinham status especial. A carne só podia ser vendida nas bancas destinadas a ela, e não podia entrar retalhada, ou seja, deveria ser cortada - com serrote, não com machado no próprio Mercado. O carniceiro deveria pesá-la à vista do consumidor, sob pena de multa. Assim que terminassem suas vendas, carniceiros e

14 APESC. Regulamento do Mercado Público, Art. 22. 
pescadores eram obrigados a lavar suas bancas. Caso fossem advertidos pelo Guarda por vender carne estragada, incorreriam em multa, e a carne seria lançada fora, o mesmo valendo para o pescado. Havia também um responsável pela aferição de todos os pesos e medidas de secos e molhados do Mercado, contratado pelo prazo de um ano. No ano de 1855, quem ganhou a licitação foi José Manoel da Silva, que pagaria para isso $422 \$ 100$ réis, em quatro parcelas.

Observamos, portanto, que ao crescente controle que se tentava impor à população de escravos e libertos, aliavam-se os esforços de regulamentação para a venda dos gêneros alimentícios. Expressa tanto no Regulamento do Mercado como no Código de Posturas, estava a preocupação com os atravessadores e a qualidade dos alimentos ou a venda de comida estragada - atenção especial à carne verde, que foi objeto de reiterados esforços de controle.

A julgar pelas proposições da Câmara Municipal à Presidência da Província em 1850, mascates, pombeiros e negras de tabuleiro escapavam às deliberações, apesar de toda a restrição a respeito da carne. Afinal, um edital desse ano dizia que se sujeitava ao imposto de pombeiro todo aquele que vendesse carne de vaca ou outras carnes em tabuleiro pelas ruas, praças, estradas, marinhas, a bordo de navios ancorados em portos de mar ou rios, sem que a rês tivesse sido morta no matadouro público. Classificava-se como pombeiro todo aquele que comprasse gêneros alimentícios em lugares públicos, e como mascate, todo aquele que os vendesse pelos mesmos lugares. A necessária licença para a venda dos gêneros deveria ser apresentada ao Fiscal do Distrito, que poria o visto no seu verso.

Percebemos, assim - pela consonância entre os artigos do Código de Posturas e aqueles do Regulamento do Mercado -, que além da repressão às práticas de sociabilidade dos africanos e descendentes dentro e fora da Praça, desejava-se reduzir e controlar o trânsito dos escravos, de modo a restringi-lo o máximo possível ao trabalho necessário (proibindo transitar, cantar, dançar, pernoitar e alugar casinhas no Mercado). Perpetuam-se, portanto, diferentes graus de hierarquia dentro do pequeno comércio ambulante e de gêneros de Desterro, baseado nas relações interétnicas, em questões de gênero e relativas à posição social, entre outras coisas, que se combinam e modificam através do tempo. É de duvidar que se tenha 
162 podido realmente "controlar" o acesso dos negros ao interior do Mercado, e menos ainda aos seus arredores; e a crermos em Oswaldo Cabral, os "indesejáveis" continuavam a frequentá-lo (meretrizes, "pretos vadios", bêbados), frustrando as primeiras tentativas de limpeza social do centro de Desterro. Eivado de seu próprio preconceito em relação às classes populares, o autor escreve que "O Mercado da Praça, pelo ajuntamento, em suas imediações, das pessoas mais brutas da cidade - escravos, carregadores, vendeiros, pombeiros, marinheiros, soldados - sempre foi lugar de badernas, algumas simples acertos de contas resolvidos a tapa, outras mais sérias, solucionadas à faca...". ${ }^{15}$

A curiosa associação entre "vagabundos", "mendigos" e "pretos vadios" em ajuntamentos que, obviamente, eram compostos basicamente de trabalhadores a "escravos, carregadores, vendeiros, pombeiros, marinheiros, soldados" foi uma tendência que persistiu de meados da segunda metade do século XIX a seu auge na Primeira República. Um olhar mais cuidadoso revela que a utilização dos termos "vagabundo" ou "vagabundagem" dificilmente refere-se ao não trabalho desses homens ou mulheres, mas a diversos outros fatores, sobretudo ocupações temporárias ou autônomas e moradias incertas e à dificuldade de controle que essas camadas impunham às autoridades pela sua própria autonomia.

As quitandeiras, por exemplo, apesar do serviço prestado, eram frequentemente citadas como estorvo, ou ao menos, como presença desagradável e destoante da imagem de cartão-postal que homens como Antero de Brito tinham em mente para as capitais do Império. $\mathrm{O}$ dito presidente da província chegou a atribuir o que considerou como baixos índices de criminalidade de Santa Catarina ao número relativamente pequeno de escravos no total da população. Por isso, no relatório de 1848, sugeriu que se acabasse com o imposto (mísero) de $5 \$ 000$ réis sobre cada escravo que saísse de Santa Catarina, e que, ao contrário, fosse oferecido o prêmio de $10 \$ 000$ ao proprietário para cada escravo vendido para fora, "para cá nunca mais voltar". É provável que ali estivesse o germe da visão que até hoje predomina sobre o estado, acerca da ausência de população afrodescendente, que tem sido progressivamente rediscutida e contestada. $O$ período abordado neste artigo corresponde à terceira fase da presença de africanos na Província, como mostrou Beatriz Mamigonian: a partir

15 CABRAL, 1972, p. 195-197. 
de 1831 (data de promulgação da lei antitráfico para o Brasil), a entrada de africanos em Santa Catarina caiu drasticamente, e a manutenção e o crescimento da população escrava passou a se dar pelos nascimentos. Entretanto, ao contrário do que queriam Antero de Brito e seus pares, o tráfico interprovincial apenas teria impacto significativo na diminuição da população escrava a partir de 1870.

Homens como ele rejeitavam a ideia de incorporação dos descendentes de africanos à sociedade de Santa Catarina. Quando elaboravam e executavam projetos, baixavam decretos, assinavam leis, tinham, no mais das vezes, a intenção - como vimos no caso do Código de Posturas e do Regulamento do Mercado - de excluir escravos e libertos, africanos e seus descendentes. Estes, por sua vez, lutavam como podiam para seguir adiante e conquistar melhores condições de vida.

\section{Africanos e seus descendentes}

Nesse contexto, percebemos a importância do "sobrenome" que Maria adotou: Mina nos remete ao tráfico de escravos e à diversidade de etnicidades de origem africana que aportaram no Brasil. A expressão "mina", que teve diversos significados em diferentes tempos e lugares, foi, em seus primórdios, ligada ao tráfico atlântico. Eram assim classificados pelos traficantes os escravos embarcados na Costa da Mina, região ao leste do porto de Elmina (feitoria de São Jorge da Mina, construída pelos portugueses em 1492 para comerciar na Costa do Ouro, atual Gana), muito embora as formas como os povos se autodefinissem nessa área e nas regiões próximas fossem outras. A designação continuou a ser utilizada de forma geral para a região próxima, à esquerda de Elmina, quando o maior porto de comércio dessa região para o Brasil passou a ser Uidá, ou Ajudá, no atual Benin.

Em terras brasileiras, essa atribuição foi reapropriada e ressignificada pelos próprios africanos em diferentes momentos. Para os lugares sobre os quais se tem mais informações, como Rio e Bahia, muitos historiadores tendem a afirmar que, em certo momento, os africanos de origem "mina" (nagôs e jêjes, ou iorubás e ewes, jalofos, mandingas e outros) passaram a assumir uma identificação coletiva em relação ao termo, em oposição a outros grupos, como os que vinham das regiões 
da África Central, como Benguela, Congo e Angola. Estes últimos foram agrupados num grupo linguístico maior conhecido como "bantu", em função das raízes linguísticas comuns entre os diversos povos daquelas regiões da África. Os africanos originários desse grupo eram maioria nas regiões cafeeiras do sudeste (São Paulo, Rio de Janeiro e Minas Gerais). Já os africanos que saíam da região da Costa da Mina, por causa das rotas do tráfico, iam parar, majoritariamente, no porto da Bahia, mas muitos acabaram sendo reenviados ao Rio de Janeiro, em meados do século XIX.

Sabemos que, no Brasil, africanos e seus descendentes desenvolveram estratégias para ganhar autonomia mesmo na condição de escravos. No caso dos escravos "ao ganho", mulheres e homens andavam pelas ruas com relativa autonomia, oferecendo seus serviços a quem por eles pagasse. Eram eles trabalhadores do porto, sapateiros, ferreiros, amas de leite, domésticas, carregadores, carroceiros, lavadeiras, prostitutas e, como era o caso de Maria, quitandeiras. Conforme seus arranjos com os senhores, após pagarem o "jornal" diário ao proprietário ou proprietária, o que restasse lhes pertencia. Foi assim que muitos escravos e escravas juntaram seu pecúlio e compraram a sonhada carta de alforria. Mas essa era apenas uma modalidade entre formas bastante diversificadas e complexas de conseguir a sonhada liberdade. Muitas vezes, ela vinha em gotas, e certamente cada uma delas duramente trabalhada e merecida. Grande parte era estabelecida sob certas condições, muitas delas bastante impressionantes para nossos olhos contemporâneos, mas muitas vezes semelhantes às condições de trabalho dependente de outros sujeitos no mesmo período.

O caso de Maria Mina é exemplar: comprou sua alforria em 1860, provavelmente vendendo gêneros. Embora por essa época o proprietário ainda não fosse obrigado a aceitar a transação, ele o fez. Mesmo mediante pagamento, legalmente, o proprietário poderia recusar-se a alforriá-la. Apenas após a aprovação da lei de 1871, que libertava o ventre da escrava, os escravos passaram a ter o direito legal ao pecúlio e à compra da própria alforria, ou seja, a lei obrigava o(a) proprietário(a) a aceitar o pagamento pela alforria do escravo ou da escrava se lhe fosse oferecido o valor do mercado. Esta certamente fora uma conquista anterior.

O fato é que Luis de Santa Anna Carpes aceitou a alforria de Maria Mina, talvez porque apesar de ainda não estar objetivado na letra da lei, 
era um direito costumeiro dos escravos; ou, quem sabe, porque precisasse do dinheiro. Provavelmente, as duas razões e outras mais. Por isso, Maria pagou um bom preço: 800 mil réis, o que leva a crer que era ainda jovem e apta ao trabalho. É provável também que Maria fosse reconhecida como boa comerciante, como rezava a tradição mina. Os resultados de pesquisas de diversos historiadores sobre escravos urbanos e as atividades comerciais mostram a supremacia numérica dos minas no ofício de quitandas, sobretudo das mulheres. Descritas por alguns viajantes como de porte altivo, eram reconhecidas pelas marcas peculiares que tinham no rosto, pelos panos da costa com que se vestiam e os turbantes que levavam na cabeça, sobre os quais qual repousavam cestos com frutas e legumes para a venda. A aptidão das minas para o comércio e para a acumulação pecuniária que possibilitaria pagar pela própria alforria está relacionada tanto à sua origem da África Ocidental quanto à experiência da diáspora e do cativeiro. Como explicam Eugênio Líbano Soares e Flávio dos Santos Gomes: “A forte ligação da África Ocidental com o mundo muçulmano transformou a região em um dos extremos da complexa rede de caravanas do deserto e municiou diversos povos com uma densa tradição comercial". ${ }^{16}$ Mas os autores atentam para a constante transformação dessas tradições, reconstruídas na diáspora, ou seja, na experiência e no enraizamento social desses homens e mulheres que vinham como escravos para diferentes regiões do Brasil.

Feito este intervalo, a história de nossa Maria Mina do Desterro, que ocupava uma vaga no vão do Mercado Público, parece ganhar novos contornos: em setembro de 1882, 22 anos depois de sua alforria, ela estabeleceu um contrato com outro militar - desta feita, o coronel Alves de Brito -, para libertar um escravo que afirmava ser seu sobrinho. $O$ pardo Manoel tinha então 24 anos de idade, e no momento do acordo, estava retido para ser vendido no Rio de Janeiro. A iniciativa de Manoel e Maria, portanto, pode ter sido uma reação desesperada para evitar a partida forçada do escravo, nascido na Província de Santa Catarina (vila de Tubarão), para o Rio, o que provocaria o constrangimento de seus laços de família e sociabilidade, além da desorganização de seus possíveis arranjos de sobrevivência.

16 SOARES; GOMES, 2007, p. 199. 
Assim, Manoel teria ficado livre a partir da assinatura do contrato entre Alves de Brito e Maria Mina, que se comprometia a pagar $900 \$ 000$ réis pela liberdade do sobrinho (apenas $100 \$ 000$ a mais do que a sua própria, anos atrás). Como entrada, o coronel recebeu $232 \$ 000$, ficando Maria obrigada a pagar o restante, $668 \$ 000$, "em prestações menores nunca inferiores a $20 \$ 000$ ". Mas aqueles eram outros tempos, e Maria e Manoel mostraram que sabiam como usar a lei de 28 de setembro de 1871, que além de libertar o ventre, também permitia ao escravo a compra da própria alforria através do pecúlio acumulado. Em abril de 1883, Manoel, através de seu curador, propôs a quitação do pagamento de seu valor junto a seu senhor através de pecúlio acumulado, que era nada menos do que os 493 mil réis já pagos por Maria a Alves de Brito. O escravo alegava enfermidade e citava o "estado diferenciado da escravidão" para argumentar que o pecúlio era suficiente para servir como indenização ao proprietário. Furioso, mais por ter seu "direto de propriedade" contestado por uma ex-escrava e outro que ainda considerava escravo (visto que o valor combinado ainda não fora pago) do que pela quantia em si, o coronel respondeu ao apelo negativamente. O que nos interessa aqui, no entanto, é o conteúdo da resposta que endereçou ao juiz de órfãos, acusando Maria de "má-fé" e "abuso de confiança" por se utilizar de artifícios para não pagar o restante da quantia devida. Afirmava ele então que Manoel, malgrado o que dizia o contrato, não podia ter parentesco com Maria, pois ela era africana da Costa da Mina, e ele, nascido em Tubarão. Assim, Maria estaria usando os serviços do pardo, que com ela morava desde que fora firmado o contrato, como escravo de ganho empregado no serviço marítimo. Segundo ele, o pardo Manoel era robusto e estaria sendo ocupado nos botes e catraias de serviço marítimo do porto, ganhando entre $40 \$ 000$ a $100 \$ 000$ mensalmente. Consequentemente, afirmava, Manoel devia estar pagando a Maria uma boa quantia em jornais.

Alves de Brito evidenciava então sua firme crença em Maria como a estrategista de toda aquela situação. Com essa desconfiança, trazia à tona uma situação nada incomum no período: a compra e a utilização de escravos por ex-escravos, que dessa forma acumulavam algumas propriedades e dinheiro. No Rio de Janeiro e em São Paulo, era prática corrente a existência de algumas redes comerciais entre escravas e ex- 
escravas, que emprestavam dinheiro a juros e costumavam ter escravas elas mesmas. Segundo Sheila Faria, elas provavelmente ensinavam o ofício da quitanda, que propiciaria às escravas algum pecúlio, facilitandolhes a alforria. Algumas chegavam mesmo a enriquecer relativamente, o que sabemos através dos testamentos e inventários que deixaram, além dos testemunhos de viajantes estrangeiros. Assim, o caso de Maria e, sobretudo, a desconfiança do coronel Alves de Brito mostram que isso ocorria também no Desterro do século XIX.

Se a suspeita tivesse razão de ser, poderíamos afirmar que Maria não era pobre e estava vivendo do trabalho de Manoel, como faziam várias senhoras brancas e de boa família, suas contemporâneas. Era comum em Desterro que senhoras viúvas ou solteiras vivessem dos ganhos de seus escravos, dependendo quase inteiramente deles. Às vezes, tinham apenas uma escrava ou um escravo, e grande parte da sua renda (quando não exclusivamente) vinha do jornal pago por eles, muitas vezes obtido através da venda - ambulante ou no Mercado - de produtos de quitanda ou de comida pronta.

\section{O novo mercado público de Florianópolis}

A pedra fundamental do Novo Mercado foi lançada em 1896, na Rua Altino Correa (atual Conselheiro Mafra), entre as ruas Jerônimo Coelho e Deodoro. O Mercado Velho foi demolido em 1899. Em 20 de maio de 1898, durante a licitação para o arrendamento das 15 casinhas do Novo Mercado - construído na Rua Altino Correa (atual Conselheiro Mafra), a alguns metros do antigo Mercado - foram feitas 23 propostas. ${ }^{17}$ Entre elas, duas eram de uma mulher, Jovita de Castro Gandra, e uma de Antônio de Castro Gandra (ele próprio um dos construtores do Mercado). Os preços dos aluguéis oscilaram entre 56 e 25 mil réis. ${ }^{18}$ Ali não havia mais espaço para pessoas como nossa conhecida, a preta forra Joanna Prates. Se em 1855 uma mulher, negra e forra fora capaz de alugar uma daquelas casinhas por $6 \$ 600$ réis - ainda que por apenas dois semestres -, isto não se repetiria nas décadas seguintes no primeiro ou no segundo Mercado.

\footnotetext{
17 AHMF. Livro n. 298. Atas de concorrência do Mercado 1898-1928, fls.01v e 2f.

18 Ibidem.
} 
Caso o preço do aluguel dos boxes não fosse impedimento suficiente, havia o "esclarecimento" fornecido pelo artigo terceiro do regulamento do Mercado, definindo o tipo de pessoa a quem se concederia o direito a alugar um box: "As casinhas serão alugadas a pessoas morigeradas e de bons costumes e o contrato de aluguel se fará por concorrência pública". ${ }^{19}$ Ali, como vimos, só se admitiram pessoas de "vida exemplar". Esse tipo de cláusula servia para excluir aqueles considerados "indesejáveis", entre os quais muitos ex-escravos, certamente.

O Mercado continuaria a ser o centro do comércio de alimentos, mas agora, como exemplo de "modernidade e civilidade" dos habitantes de Desterro, não necessitava somente de serviços, mas também de status. Com a aproximação do final do século XIX, a despeito da Abolição e da mudança de regime, aqueles que não eram exatamente portadores da imagem que os modernizadores de Florianópolis queriam para si passaram a ser cada vez mais excluídos daquele espaço.

\section{Conclusão}

Como vimos, o primeiro Mercado Público de Desterro foi, em meados do século XIX, importante fator de aglomeração de africanos e descendentes em luta pela sobrevivência cultural e econômica, além de ter ajudado a concretizar suas expectativas de liberdade. Os primórdios da história de sua construção correspondem aos primeiros ensaios dos debates sobre a substituição do braço escravo no Império brasileiro, à proibição do tráfico de escravos em 1831 e às revoltas escravas que amedrontaram autoridades e proprietários na Bahia e no Sudeste.

Assim, o Regulamento do Mercado, em consonância com o Código de Posturas de 1845, expressa a preocupação com aglomerações, batuques e festas, frequentemente, momentos de resistência cultural e política, como mostrava o quadro de revoltas escravas no período imperial da primeira metade do século XIX. A menção explícita à proibição dos reinados africanos no Código, ao lado de outras proibições, denuncia também o medo que as autoridades tinham de uma possível construção de solidariedades entre escravos e libertos fundamentadas pelas origens

\footnotetext{
19 COLEÇÃO DE LEIS DO MUNICÍPIO DE FLORIANÓPOLIS, 1901.
} 
africanas, baseadas também na experiência de outras províncias do Império brasileiro.

Por muito tempo, o desejo que tinham os legisladores e governantes de que os africanos e seus descendentes desaparecessem dos projetos de construção da nação pareceu ter-se tornado realidade, ao menos no caso dos livros de história e outros tipos de registro. Apesar de os sobrenomes com referência às nações africanas terem escasseado no final da década de 1860, a presença de Maria Rosa, Thereza, Faustina e tantas outras mulheres que alugavam os lugares de quitanda no Mercado Público revela um grande número de trabalhadores pobres, livres, libertos, escravas e escravos que ainda atuavam no principal centro de comércio do núcleo urbano de Desterro.

Os registros que levam à trajetória de Maria Mina, africana que em Desterro desenvolvia e utilizava suas aptidões de comerciante para ocupar um lugar no Mercado e comprar sua própria alforria e a de outro escravo, mostram que ela se inseriu nos meandros do pequeno comércio e do crédito da cidade para garantir seu sustento ou até mesmo acumular alguns bens. A história dela e a do preto liberto Lourenço - que tinha uma pequena propriedade de frente para o mar, moinhos e pequenas canoas para transportar a produção - mostram que ainda há muito que contar sobre as trajetórias de africanos e africanas na Ilha, sua participação nas redes de produção e distribuição de alimentos e serviços e suas estratégias de resistência econômica e cultural.

\section{Fontes}

\section{ARQUIVO DO FÓRUM MUNICIPAL DE FLORIANÓPOLIS}

1ํㅡㅁ Vara de Família: Cx. 02 de 1883, n. 199. Inventário de Feliciano Alves de Brito. Relatórios de Presidentes de Província (1838-1855).

ARQUIVO HISTÓRICO MUNICIPAL DE FLORIANÓPOLIS.

Livros Caixa de receita e despesa da Câmara Municipal de Desterro (1851-1852, 1854-1855, 1867-1868).

Termos de arrematações da Câmara Municipal (Arrematação das casinhas do Mercado Público) 1855-1880. 
Livro n. 298. Atas de concorrência do Mercado 1898-1928.

Código de Posturas da Câmara Municipal de Desterro (1845).

Registro da Correspondência da Câmara Municipal desta Cidade às Autoridades Civis e Fiscais do Município (1858-1869).

\section{ARQUIVO PÚBLICO DO ESTADO DE SANTA CATARINA}

Regulamento do Mercado Público. Ofícios da Câmara Municipal à Presidência da Provincia 1850. Fls. 120-126.

\section{CARTÓRIO DO RIBEIRÃO DA ILHA}

Livro n.12, 1881-1882. Escritura de doação que faz Loren digo o preto liberto Lorencio Carlos da Cunha (sic) a Leopoldina Francisca Allano e seus quatro filhos de nome Floriano, Joaquim, Bento e Manoel, como abaixo se declara.

\section{Referências}

CABRAL, Oswaldo Rodrigues. História de Santa Catarina. Florianópolis: Ed. Lunardelli, 1987. 1971. . Nossa Senhora do Desterro. Noticia. I e II. Florianópolis: Ed. da UFSC, . Nossa Senhora do Desterro. Memória I e II, Florianópolis: Ed. da UFSC, 1972.

COLEÇÃO DE LEIS DO MUNICÍPIO DE FLORIANÓPOLIS. Disposições sobre o uso do Mercado Novo; Lei no 56 - 23/04/1898. Florianópolis: Typ. da Livraria Moderna, 1901.

FARIA, Sheila de Castro. Mulheres forras: riqueza e estigma social. Tempo.

Revista do Departamento de História da Universidade Fluminense, Niterói, v. 5, n. 9, jul. 2000.

HÜBENER, Laura Machado; O comércio da cidade do Desterro no século XIX. Florianópolis: Ed. da UFSC, 1981.

LAW, Robin. Etnias de africanos na diáspora: novas considerações sobre os significados do termo "mina". Tempo. Revista do Departamento de História da Universidade Fluminense, Niterói, v. 10, n. 20, p. 109-131, jan. 2006.

LIMA, Henrique Espada. Sob o domínio da precariedade: escravidão e os significados da liberdade de trabalho no século XIX. Topoi, Rio de Janeiro, v. 6, n. 11, 2005. 
MAMIGONIAN, Beatriz. Em nome de beleza, comodidade e benefício público: um projeto de intervenção urbana para Desterro no século XIX. Geosul (UFSC), Florianópolis, v. 14, n. 28, 1999, p. 179-188.

. Africanos em Santa Catarina: escravidão e identidade étnica (17501850). In: FRAGOSO, João Luis Ribeiro; FLORENTINO, Manolo G.; SAMPAIO, Antonio Carlos Jucá; CAMPOS, Adriana (Org.). Nas rotas do império: eixos mercantis, tráfico e relações sociais no mundo português. Vitória; Lisboa; Brasília: Ed. UFES; Instituto de Investigações Científicas Tropicais; CNPq. 2006, p. 609644.

MESQUITA, Ricardo Moreira de. Mercado: do Mané ao Turista. Florianópolis. Ed. do autor, 2002.

PEDRO, Joana. Nas tramas entre o público e o privado - a imprensa de Desterro no século XIX. Florianópolis: Ed. da UFSC, 1981. . Mulheres honestas, mulheres faladas - uma questão de classe.

Florianópolis: Ed. da UFSC, 1994.

PENNA, Clemente Gentil. Escravidão, liberdade e os arranjos de trabalho na Ilha de Santa Catarina nas últimas décadas de escravidão (1850-1888).

Dissertação (mestrado em História) - Programa de Pós-Graduação em História, Universidade Federal de Santa Catarina, 2005.

PEREIRA, Magnus Roberto de Mello. Almuthasib - Considerações sobre o direito de almotaçaria nas cidades de Portugal e suas colônias. Revista Brasileira de História. São Paulo, 2001. v. 21, p. 365-395.

SBRAVATI, Daniela. Mulheres de (in)certa condição. Revista Mundos do Trabalho. v. 1, n. 2, 2009.

SILVA, Nivaldo Jorge da. A descoberta do Mercado Público. Florianópolis: IOESC, 1996.

SOARES, Carlos Eugênio Líbano. Zungú: rumor de muitas vozes. Rio de Janeiro: Arquivo Público do Estado do Rio de Janeiro, 1998.

SOARES, Carlos Eugênio Líbano; GOMES, Flávio dos Santos. Negras Minas no Rio de Janeiro: gênero, nação e trabalho urbano no século XIX. In: SOARES, Mariza de Carvalho (Org.). Rotas atlânticas da diáspora africana: da Baía do Benin ao Rio de Janeiro. Niterói: Ed. UFF, 2007. 


\section{|| Capítulo 8 ||}

\section{Victorino de Menezes: um comerciante de escravos em Desterro}

Rafael da Cunha Scheffer

Desapparecimento

Pedem-nos que chamemos a attenção das autoridades para o desapparecimento de Manuel Antonio Victorino de Menezes, que d'aqui sahiu, há quatro mezes, para São Paulo.

Esperamos que a illustrada imprensa paulistana tome em consideração o facto com a sua publicidade.

(O Conservador, 17/01/1885).

Foi recebida com indignação e horror pela nossa população a notícia do feroz assassinato de que foi vítima Manuel Antonio Victorino de Menezes na opulenta cidade de Campinas.

(A Regeneração 31/03/1885).

No mês de abril de 1885, os jornais da capital catarinense divulgaram uma série de notícias sobre as investigações do assassinato de um comerciante de Desterro, na cidade paulista de Campinas. Mas o que estaria um negociante da capital catarinense fazendo no interior paulista, e quem era este indivíduo? O que esse crime pode ter de relevante para nós?

Marcando o ato final da vida de um negociante, essa viagem e o crime servem de porta de entrada a informações sobre a vítima e sua atividade. Victorino de Menezes, considerado por alguns historiadores catarinenses como o maior comerciante de escravos de Desterro, foi 
morto em Campinas justamente em uma de suas viagens de negócios, durante a qual cobrava dívidas neste município. $O$ destaque dado ao episódio e as informações levantadas por sua cobertura na imprensa apontam uma série de questões ligadas à experiência de Victorino. O que pretendemos, através da análise da trajetória do comerciante, é levantar mais informações sobre sua atividade em Desterro. Isso nos possibilita observar práticas que foram comuns a outros homens envolvidos nesse mesmo negócio.

Com a proibição, de fato, do tráfico de escravos africanos a partir de 1850, senhores interessados em manter e ampliar seus plantéis tiveram de recorrer ao mercado nacional de cativos. Assim, as transferências de escravos entre as diversas regiões do Império foram ampliadas enormemente. Cerca de 222.500 pessoas foram comercializadas entre as diversas regiões do Brasil, entre 1850 e 1881, sendolevadas principalmente ao Sudeste, para as lavouras de café em expansão. O impacto dessa intensificação atingiu diferentes modos de vida e relações entre senhores e escravos, pois estes eram enviados para contextos completamente diferentes daqueles aos quais estavam acostumados, sem seus conhecidos e familiares, sendo inseridos em outras formas de convívio e trabalho. Em vez de castigos, em alguns momentos, os senhores ameaçavam seus escravos com a venda, como forma de mantê-los disciplinados.

Podemos imaginar que para um escravo nascido em Desterro, criado junto aos pais cativos e mais um ou outro escravo, trabalhando a terra muitas vezes com a família do seu senhor, a mudança para fazendas de café do Sudeste poderia ser traumática. Muitas dessas fazendas eram propriedades com dezenas de escravos, disciplinados por feitores e executando um trabalho que tinha fama, entre os próprios cativos, de duro e exaustivo. Por isso, temendo essas mudanças, alguns cativos tomaram decisões drásticas para não serem enviados a lugares que imaginavam ser bem piores do que aquele no qual viviam. Em 1873, um jornal de Desterro noticiou a tentativa de suicídio de um escravo, que se atirou ao mar quando descobriu que o navio no qual havia embarcado rumava pro Rio de Janeiro. Na historiografia nacional, vemos muitos outros casos como esse, assim como de escravos que agridem ou matam os comerciantes e encarregados por sua venda ou transporte e depois fogem ou se entregam à polícia. 
De qualquer forma, a diminuição da oferta de escravos, por conta do fim do tráfico com a África, levou ao aumento do preço da mão de obra já nos primeiros anos da década de 1850. Além disso, a valorização do preço do café, na segunda metade do século XIX, aumentou ainda mais o preço dos escravos na região Sudeste, principal produtora e exportadora do produto. Em alguns momentos, os escravos valiam quase duas vezes mais no Sudeste do que no Sul ou Nordeste do país, motivando senhores que não os tinham em atividades tão lucrativas a conseguir um bom dinheiro com sua venda, e negociantes a lucrar com essas transferências. Assim, a oportunidade de negócios levou alguns comerciantes de Desterro a também negociar escravos em determinados períodos de grande procura e bons preços no mercado do Sudeste. Pessoas como Constantino Ferraz Pinto de Sá, que, em 1870, anunciava que sua loja recebia do Rio de Janeiro ferragens, tintas, objetos de armarinho e escritório, livros de instrução primária e secundária, entre outros, assim como também anunciava que comprava cativos para revendê-los no Sudeste.

Entre 1850 e 1881 (ano em que o tráfico entre as províncias tornou-se impraticável, em função dos altos impostos estabelecidos pelas províncias importadoras), podemos identificar 23 pessoas envolvidas com este negócio na capital catarinense. Eram comerciantes em geral, figuras bem colocadas na sociedade local, respeitáveis integrantes de sua elite, alguns participando da vida pública como deputados, e que não sofriam qualquer tipo de constrangimento por suas atividades. Entre eles, destacava-se a figura de Manoel Antônio Victorino de Menezes.

\section{Um comerciante entre províncias}

Manoel Antônio Victorino de Menezes teve uma vida incomum para um rico comerciante da praça de Desterro. Como ficamos sabendo pelo seu testamento, publicado em um jornal da cidade (A Regeneração, 01/05/1885), ele afirmava ter nascido na província do Rio de Janeiro e, o que nos chama mais a atenção, ser "filho de pais incógnitos". O desconhecimento da identidade de seus pais nos coloca uma série de dúvidas sobre seus primeiros anos de vida. Quem eram seus progenitores e por que o haviam abandonado? Quem o teria criado? Onde e sob quais condições ele cresceu? Multiplicam-se os questionamentos, e a ausência 
de informações mais precisas sobre seu local de nascimento impede a localização de outros documentos para obtermos essas respostas. Ao mesmo tempo, a falta de informações pode indicar a intenção de omitir um passado, evitando o registro de dados indesejados sobre origem e vivência, que poderiam prejudicar a manutenção do status social alcançado por Victorino através de seus negócios.

Por outro lado, a cobertura jornalística de seu assassinato feita por periódicos de Campinas ajuda a elucidar algumas questões sobre sua trajetória e aparência. Na edição de 9 de abril de 1885, o Diário de Campinas noticiou que retratos falsos de Victorino vinham sendo vendidos na cidade de São Paulo. E, para responder à curiosidade sobre o assassinado, tratou de descrevê-lo:

[...] era Victorino de Menezes de estatura um pouco acima do regular, busto algum tanto curvo e de presença agradável.

Tinha fronte espaçosa, rosto oval, nariz levemente aquilino, olhos castanhos e tez morena. Usava cabelo curto, bigode e cavaignac, o que lhe dava certa aparência militar. Os fios do cabelo eram grisalhos e os das barbas quase todos brancos, pelo que costumava Victorino pintá-los a miúdo.

Nunca trazia consigo armas, confiando em sua robustez, no caso de ser preciso defender-se de qualquer agressão.

Era afável no trato, denunciando bonhomia e gostava de conversar, manifestando então humor alegre.

Possuía alguns conhecimentos e apreciava muito observações astronômicas. Na sua casa em Santa Catarina existe um telescópio de que ele fizera aquisição, afim de contemplar os astros.

Muito metódico em todos os atos da sua vida e pontual em satisfazer as suas dividas, incomodava-se sempre que era forçado a alterar os seus hábitos ou quando alguém deixava de solver á risca os compromissos que com ele tinha. Quando algum devedor deixava de pagar-lhe o débito, preferia resolver imediatamente as dificuldades, recebendo qualquer quantia a uma espera prolongada, ou a recorrer aos meios judiciais.

Ao mesmo tempo em que fornece uma série de informações, a descrição traz novos problemas para entendermos exatamente o que o jornalista tentava dizer e como ele deve ser interpretado. A descrição 
da "tez morena", a princípio, pode sugerir uma ascendência africana e, portanto, uma das informações que Victorino supostamente pretendia ocultar em seu testamento, com a indicação de "pais incógnitos". Porém, não temos outros indícios que nos permitam confirmar essa hipótese. Mesmo sem respostas sobre sua criação, podemos perceber, através de alguns relatos, que ele recebeu boa educação. Nos depoimentos de pessoas interrogadas no processo do seu assassinato, temos a informação de que "Victorino era homem sério, de costumes morigerados e methodicos e de hábitos regulares".

Na mesma edição de 9 de abril de 1885, o sobredito jornal publicou uma entrevista com Sebastião Pereira da Silva, genro de Victorino, que estava na cidade acompanhando o processo. Nela, foram explorados traços de personalidade e da trajetória do comerciante que dificilmente seriam retratados por outras fontes. O genro de Victorino indicou que este "fora antigamente negociante no Rancho Novo, próximo de Valença, mudando-se depois para Itapemirim, onde tivera loja de fazendas." Somente em um momento posterior é que teria se envolvido no comércio de escravos, vendendo-os para a Corte e para a província de São Paulo. A referência à cidade de Valença, relacionada à indicação de que ele havia nascido na província do Rio de Janeiro, nos leva a acreditar que pudesse ser natural do Vale do Paraíba. Também cabe ressaltar que essa trajetória de deslocamentos, do Rio de Janeiro para o Espírito Santo e depois para Santa Catarina, buscando novos negócios, foi outro fator de diferenciação entre Victorino e muitos dos outros negociantes de Desterro; sem dúvida, isso deu ao comerciante uma perspectiva que o ajudou a desenvolver seus negócios na província de São Paulo.

Os deslocamentos e viagens parecem mesmo ter sido bastante presentes na vida familiar de Victorino. O comerciante foi casado com dona Izabel Francisca de Menezes, com quem teve duas filhas, Maria (que já havia falecido em meados da década de 1870) e Leonor. Por meio de seu testamento, ainda ficou claro que, nos primeiros anos em que esteve em Desterro, a relação com a família se deu a distância. Os primeiros registros da presença de Victorino na cidade remontam a 1868; em 1874, sua mulher e filhas continuavam residindo em Itapemirim, no Espírito Santo. A duração da relação de distância com a família não está explícita, mas observamos que perdurou, ao menos, até 1880. Nesse ano, o negociante 
passou uma procuração para a venda do escravo Ignácio, que estava em Itapemirim, em companhia da esposa do comerciante.

As viagens e as visitas de Victorino à família talvez fossem constantes, aproveitando as viagens de negócios realizava no Sudeste. Em 1871, seu nome aparece na relação de passageiros que chegaram à capital catarinense vindos do Rio de Janeiro, a bordo do vapor Calderon, acompanhado de sua senhora, duas filhas e dois criados. Essa relação poderia ter se dado da seguinte forma: Victorino parece ter constituído família em Itapemirim, Espírito Santo; talvez esse fosse o local de origem de sua esposa. De qualquer forma, ele e sua família tinham propriedades naquela região, e sua esposa e filhas parecem ter continuado a viver em Itapemirim, fazendo visitas a Santa Catarina. O comerciante poderia visitá-las em suas idas ao Sudeste. A mudança da família para a capital catarinense somente pode ser confirmada através da análise do processo de seu inventário. Conturbado por petições e irregularidades, o inventário e a partilha dos seus bens nos fornecem pistas importantes, apontando que dona Izabel residia em Desterro, juntamente com sua filha Leonor e o marido desta.

Já sobre as relações que o negociante desenvolveu em Desterro, os indícios examinados são mais obscuros. Ele criava e educava o menor Hercílio Victorino de Menezes, filho de Maria Margarida Duarte, mulher liberta e parda. Em 1880, juntamente com sua esposa, Victorino de Menezes doou para este menor seu sobrado localizado no Largo do Palácio, n. 18, e passou a pagar aluguel a Hercílio, cujo valor (50 mil réis mensais) o comerciante se comprometeu a guardar até a maioridade do menino. O valor do imóvel foi calculado pelo próprio negociante em 6 contos de réis. Qual seria a motivação dessa doação de uma casa de alto valor, no centro da cidade, próximo ao centro do poder local? A mãe do menor fora escrava de Victorino e vivia em sua companhia até a chegada de dona Izabel. No testamento de 1874, ele deixou a ela 2 contos e 500 mil réis, mais 1 conto e 500 mil réis para seu filho recém-nascido, e ainda "todos os utensílios, roupa e todos os mais objectos de uso domestico que se acharem em minha [de Victorino] residência." Através desses indícios, podemos imaginar que Hercílio fosse filho de Victorino.

A inserção deste comerciante na sociedade local é outro aspecto nuançado naquele testamento firmado em 1874. Na distribuição que 
deveria ser feita de seus bens e alguma quantidade de dinheiro, Victorino elencou uma série de compadres e afilhados na Ilha de Santa Catarina, todos residentes em freguesias do interior. Em Sambaqui, ele deixou 800 mil réis a duas filhas de José de Queiroz, entre as quais, sua afilhada Leopoldina; deixou 200 mil réis à outra afilhada, Cecília, filha de Eduardo Levéque; além de mais 200 mil réis a seu afilhado Antonio, filho de seu compadre Veríssimo. Deixou propriedades e dinheiro para conhecidos na região de Canasvieiras e também 400 mil réis a Antônio Bernardino dos Santos Castão, descrito pelo testador como "súbdito português e companheiro de minhas viagens". Certamente, esse último era um encarregado de Victorino e, em vista disso, ficamos imaginando como se conheceram e estabeleceram uma relação de amizade através de tal vínculo de trabalho e proximidade.

Mesmo no círculo da sociedade comercial, percebemos a aproximação de Victorino de Menezes com alguns negociantes da praça. Suas disposições testamentárias apontavam essa ligação, pois Firmino Duarte Silva, comerciante local, além de Constâncio José da Silva Pessoa Junior, morador de São José, foram incumbidos de executar as vontades finais de Menezes. Localizamos igualmente, em algumas procurações, uma parceria momentânea entre Victorino e outros comerciantes desta praça. Em dezembro de 1874, Victorino de Menezes, em parceria com a casa Motta \& Costa e Frederico Noronha, foi encarregado de vender o escravo Joaquim em qualquer lugar do Império. Em 1879, foi João Pombinho da Silva quem estabeleceu uma parceria com Victorino, para a venda da cativa Fortunata.

Além disso, talvez por conta da extensão de suas posses, no processo de inventário de Victorino, diversos nomes da sociedade local aparecem envolvidos, como os do comerciante Manoel Moreira da Silva, do comendador José Delfino dos Santos, de João Custódio Dias Formiga, André Wendhausen, entre outros. Tentativas de inserção na sociedade local e de estabelecer melhor relacionamento com seus pares, talvez o tenham motivado a promover doações para a construção de obras na Ilha. Em alguns números dos jornais da capital catarinense, foram publicadas listas de donativos arrecadados em Desterro para a realização de obras e auxílios. Em 1874, vemos o nome de Victorino ao lado do nome de diversos negociantes locais, em uma subscrição de comerciantes para 
cobrir de zinco o trapiche do Palácio. Em 1877, também participou de uma subscrição para socorrer vítimas das inundações em Portugal, e em 1880, vemos seu nome entre os que auxiliaram monetariamente o Socorro dos Pobres quando da inundação de Itajaí.

Como um homem de sua época, percebemos alguns dos padrões compartilhados por senhores e comerciantes na maneira como Victorino de Menezes investia seu dinheiro. Através do inventário, observamse algumas opções de investimento deste comerciante. $\mathrm{Na}$ análise de sua riqueza, destacou-se a opção pela compra de imóveis. De um montante calculado em 47 contos e 593 mil réis, mais da metade do valor (30:043\$000 réis) estava investida em imóveis e terras, "bens de raiz", como eram chamados. Distribuíam-se em dois sobrados - um na Praça Barão de Laguna, antes conhecida como Largo do Palácio; e outro na Rua João Pinto - e casas e terrenos no atual centro de Florianópolis. Havia também fazendas na Enseada de Brito e no lugar denominado Serraria, em São José. Os aluguéis dos imóveis na cidade rendiam cerca de 790 mil réis mensais a Victorino. Por fim, havia 12 contos e 700 mil réis a receber de diversas dívidas e empréstimos, entre eles, 7 contos de réis de Manoel Jorge Graça, comerciante de Campinas.

Ganhando dinheiro com o mercado de escravos, Victorino não deixou de participar dele, atuando como senhor de escravos. Através do testamento, sabemos que o comerciante, em 1874, era senhor de quatro cativos. Maria Margarida, a parda que libertou sob condição; Mariano e Ignácio, que acompanhavam sua esposa no Espírito Santo; e Manoel, que estava em sua companhia. Como negociante e possuidor de pequenas propriedades, aparentemente não precisava de grande contingente de cativos, mas os possuía para desenvolver atividades variadas-domésticas, de cuidado das propriedades ou mesmo no auxílio ao seu negócio. Talvez Manoel e Maria, os cativos que em sua companhia em Desterro, tivessem um papel ativo no cuidado dos escravos que esperavam o embarque para o Sudeste.

Em 1873, Menezes libertou Maria Margarida, de dezesseis anos, com a condição de que ela o servisse durante mais cinco anos. Conforme conjeturamos acima, a libertação de Maria parece não apenas envolver os bons serviços prestados, destacados pelo comerciante. Sendo apontada no testamento como a mãe do recém-nascido Hercílio Victorino de Menezes, 
é provável que a concessão da alforria estivesse relacionada à sua gestação. Lembramos que a doação ao filho da liberta, posteriormente tutelado por Victorino, mostrou que havia uma relação entre eles, reforçando a ideia de que o menino era filho do comerciante e da então escrava.

A libertação de uma cativa e a venda de outro (Inácio) não significou o fim de sua propriedade de escravos. Em 1881, Victorino adquiriu em Desterro duas escravas domésticas. Provavelmente, a compra foi incentivada pela vinda de sua família a Desterro. Esse ato demonstra a confiança de Victorino na continuidade da escravidão, compartilhada por muitos outros senhores que negociaram diversos cativos ao longo da década. No momento de sua morte, somente uma escrava apareceu listada entre seus bens. Era justamente Bárbara, uma das cativas que havia comprado em 1881. Avaliada em 100 mil réis, ela aproveitou o momento em que seu futuro estava em jogo, em que os laços de propriedade haviam afrouxado, e juntou suas economias para comprar sua liberdade. Dessa forma, já aparece como liberta no final do processo.

Em resumo, os indícios que temos sobre a vida de Victorino e a interpretação de algumas lacunas podem nos ajudar a vislumbrar sua experiência. Ao que parece, ele nasceu em local próximo a Valença importante região escravista do Vale do Paraíba fluminense - e tinha ascendência africana. Omitir a identidade de seus pais, especialmente a da mãe, parece ter sido uma estratégia para preservar o status social conquistado através do casamento e de seus negócios, e que já poderia ter sido ameaçado por sua "tez morena".

Sabemos que ele começou a atuar no comércio (iniciando como empregado) naquela região, tendo se tornado comerciante independente em Rancho Novo. Em seguida, seus negócios o levaram a Itapemirim, na província do Espírito Santo. Região canavieira, com muitos proprietários de pequenos alambiques, o comerciante encontrou entre essas famílias uma esposa branca, dona Izabel, que lhe proporcionaria um status mais elevado. Com o dote e a herança de sua esposa, agregados aos seus esforços e recursos próprios, Victorino conseguiu ampliar suas posses e se colocar no mercado interprovincial de escravos. Sua trajetória, marcada por mudanças e viagens, parece tê-lo ajudado a perceber as oportunidades do negócio no qual se lançou com sua ida para Desterro. 


\section{"0 mais forte comprador de escravos"}

\section{ESCRAVOS}

O abaixo assignado compra escravos de ambos os sexos de 12 a 30 annos de idade, e está pagando preços mais altos do que qualquer outro.

LARGO DO PALACIO N. 16

Victorino de Menezes. (O Conservador, 14/10/1874).

Com anúncios como este, Menezes divulgava seu negócio pela cidade. Ele foi apontado por Oswaldo Cabral e Walter Piazza como o maior comerciante de escravos de Desterro. Cabral nos dá mais detalhes sobre a atuação do negociante:

Parece que o mais forte comprador de escravos por grosso que se estabeleceu no Desterro foi um tal Vitorino de Menezes, de quem já falei, que anunciava o seu nefando comércio, pela primeira vez, em 1868 [...].

Vitorino estabeleceu o seu escritório bem no coração da cidade, na Praça, à mão, pagando de contado. Dali, segundo creio, com razões para isso, os negros que comprava eram levados para um depósito que se localizava nas proximidades do cemitério (atual rua Hoepcke), senzala que ficava então numa viela que ficou conhecida como rua do Vitorino de Menezes. ${ }^{1}$

Apesar de não podermos averiguar boa parte das informações apontadas por Cabral, a análise dos jornais é condizente com sua afirmação sobre a multiplicação dos anúncios dos "negócios negreiros". Igualmente, a referência à rua que recebia o nome do comerciante é corroborada por uma queixa publicada em um dos periódicos de Desterro, que tratava da falta de cuidados e do mato que cresceu na "travessa do Victorino de Menezes". Outros indícios observados em jornais e também em livros de notas nos permitem concordar com a ideia de que Victorino possa ter sido o comerciante que mais cativos transferiu para fora da província. Isso

1 CABRAL, 1972, p. 404. 
fundamenta-se na leitura dos próprios anúncios e registros, tanto por sua duração e repetição quanto pelos volumes das encomendas que lhe eram solicitadas do Rio de Janeiro.

Entre 1868 e 1876, observamos anúncios de Victorino referentes à compra de grupos de escravos, sendo que alguns foram repetidos nos jornais durante anos inteiros. Estabelecido junto à praça (atual Praça XV), próximo ao Palácio de Governo e à Matriz, no casarão doado a Hercílio Victorino de Menezes, tal outorgante anunciava suas compras divulgando que pagava os melhores preços, além de dar gratificações a quem agenciasse negócios. ${ }^{2}$ Em geral, nenhum dos comerciantes divulgava o volume de suas encomendas, anunciando apenas que compravam escravos. Victorino, diferentemente, em alguns momentos anunciou a necessidade de comprar para satisfazer encomendas. Assim, em 30 de maio de 1869, ele divulgou uma encomenda de 80 escravos lavradores para o Rio de Janeiro. ${ }^{3}$ Outras menores apareceram em anos posteriores. No geral, considerando apenas as encomendas tornadas públicas em oito anos de anúncios, 163 escravos teriam sido encomendados e transferidos por suas mãos, sem contar as transferências corriqueiras, sobre as quais ele anunciava a compra, mas não o número de cativos.

Seu envolvimento com o tráfico interno aparece em outros registros além dos anúncios. Em alguns anos, os jornais de Desterro trazem registros da movimentação do porto, indicando entradas e saídas de navios, seus destinos e passageiros. Aí, encontramos senhores ou encarregados viajando, acompanhados de escravos. Entre eles, com alguma frequência, Victorino de Menezes, viajando com um pequeno número de cativos, em direção a algum porto do Sudeste. Em 1879, por exemplo, conseguimos observar bem esse procedimento de transporte. No dia 29 de outubro, Victorino partiu rumo ao Rio de Janeiro levando sete escravos e retornou duas semanas depois, sem escravo algum. ${ }^{4}$

A organização desse comércio interprovincial demandava, além da preocupação com transporte, uma organização da rede de comerciantes, contatos que possibilitassem a comunicação e o suprimento de encomendas. Não sabemos até que ponto as relações de comércio de

2 O Conservador, 09/06/1875.

3 O Mercantil, 30/05/1869.

4 O Despertador, 29/10 e 15/11/1879. 
escravos se sobrepunham às redes comerciais de outros produtos, cujos fornecedores pudessem também encomendar cativos aos seus contatos provinciais. A falta de outros anúncios de Victorino que apontem uma ligação de seus negócios com outras mercadorias mostra-nos uma rede de contatos para a venda de cativos que parece ter se constituído especialmente para este negócio.

Através da análise das procurações feitas diante de tabeliães, conseguimos recuperar alguns traços da construção desta rede formada por Menezes e seus parceiros. Parece ter sido prática comum no século XIX que o negociante, ao comprar um escravo, não recebesse o seu título de propriedade, mas uma procuração para revendê-lo e um recibo do "adiantamento" do valor dessa transação, pago ao então senhor. Tratavase, na verdade, de uma simples relação de compra e venda, mas registrada daquela forma para evitar o imposto cobrado sobre a transferência da posse do cativo. Esse procedimento era utilizado por Victorino de Menezes, e ao examinarmos alguns livros de notas, localizamos e identificamos sua rede de parceiros. Os livros do cartório Kotzias, localizado no centro de Florianópolis, foram pesquisados em busca das procurações que permitiam aos comerciantes negociar cativos em diversos pontos do Império. Em 10 desses livros, entre os anos de 1862 e 1880, encontramos 69 procurações que autorizavam a venda de 77 escravos. Dessas, pouco mais da metade (39 procurações) envolviam Victorino de Menezes, o que reforça o lugar de destaque que Oswaldo Cabral e Walter Piazza lhe atribuíram.

Em 1874, encontramos a primeira das procurações que mencionava Victorino. Nesta, Vicente Antonio de Pinha, morador de São José, concedeu a esse comerciante e a Frederico de Freitas Noronha, do Rio de Janeiro, poderes para realizar a venda do crioulo Adão, lavrador de 24 anos de idade. A parceria entre Menezes e Frederico Noronha, que parece ser seu contato comercial na Corte, duraria vários anos, sendo observada em diversas procurações ao longo da década de 1870 e início da próxima. Seguindo os indícios das procurações, a sociedade estabelecida pelos dois parece ter se expandido a partir de 1879. Desse ano em diante, muitas das procurações que davam poderes a eles passam também a concedê-los a Manoel Jorge Graça e, mais tarde, a Aureliano de Souza Monteiro, ambos estabelecidos na região de Campinas. Em junho daquele ano, os quatro comerciantes (Menezes, Noronha, Graça e Monteiro) receberam poderes, 
184 pela mesma procuração, para a venda do escravo Pedro, de propriedade de José Marques Guimarães e seus irmãos.

O que verificamos nessas procurações é uma cadeia de negociantes envolvidos no tráfico interprovincial. Victorino, comprador em Desterro e ponta inicial da cadeia, ao fazer as procurações com os vendedores, já estabelecia poderes para seus parceiros no restante da cadeia de transferências (ou, pelo menos, de uma parte dela). Frederico de Freitas Noronha, o contato no Rio de Janeiro, parece ter sido, por anos, a ponta final da rede estabelecida por Victorino, que ia até a chegada dos cativos à Corte. A partir daí, através dos contatos de Noronha, outra conexão levava os cativos até seus novos senhores. A expansão da rede montada por Victorino, observada no fim dos anos 1870, foi realizada em direção a outro centro de compras de cativos, identificável por conta dos novos parceiros apontados nas procurações. Manoel Jorge Graça e Aureliano de Souza Monteiro tinham negócios na região cafeeira de Campinas, província de São Paulo.

A montagem desta rede comercial de escravos mostra a organização envolvida no negócio, assim como sua importância para Victorino. Os demais negociantes de Desterro, quando estabeleciam outro procurador, referiam-se, no máximo, a um negociante do Rio de Janeiro. Victorino Menezes, através de seus contatos e viagens, expandiu sua rede até o Oeste paulista, e essa conexão para a remoção forçada de escravos catarinenses mostrou-se bastante ativa entre os anos de 1879 e 1880: dos 40 escravos vendidos por meio desses instrumentos, nada menos do que 31 foram levados através da rede que aponta Campinas como destino. O preço médio dos escravos ajuda a entender o motivo da expansão dos negócios de Victorino para essa região. Segundo a pesquisa de Warren Dean sobre a cidade paulista de Rio Claro, o preço médio de um escravo entre 15 e 29 anos, em 1880, era de dois contos e trezentos mil réis. Na mesma época, através das notas de compra e venda de escravos, observamos que o preço médio de cativos com a mesma faixa etária em Desterro era de um conto de réis.

A maneira como Victorino desenvolvia seus negócios na capital de Santa Catarina também fornece algumas pistas importantes sobre o funcionamento do tráfico interno. Segundo os anúncios, ele se comprometia a realizar o pagamento ao vendedor do cativo (a pessoa 
que passava a procuração) em dinheiro. Em anúncio de 1874, ele se comprometeu não somente a pagar em dinheiro, mas também a realizar parte do pagamento em ouro, dependendo da preferência do vendedor. Além disso, informou que pagava bem a quem agenciasse (intermediasse) a compra de cativos. Com isso, procurava ampliar sua rede de contatos e atrair mais vendedores.

$\mathrm{Na}$ outra ponta, quando Victorino negociava na Corte, era provável que realizasse a venda dos cativos catarinenses para outros negociantes, responsáveis pela redistribuição desses trabalhadores a seus futuros senhores. Nesse trato, acreditamos que Victorino também recebesse em dinheiro. Porém, com a expansão de sua rede de comércio até Campinas, essa forma de remuneração teria mudado. A possibilidade maior de os escravos chegarem diretamente aos compradores finais promovia os pagamentos a crédito. De fato, boa parte das compras feitas por fazendeiros - escravos, equipamentos e insumos - era realizada a crédito, com pagamentos após a colheita. Sendo assim, a expansão da rede até Campinas deve ter proporcionado lucros consideráveis, com a ampliação da quantidade de sócios e negócios, mas parecia determinar também períodos de espera pela satisfação de tais créditos emitidos pelos fazendeiros campineiros. É importante entender como a questão do endividamento estava presente no cotidiano do tráfico interno e mesmo no episódio do assassinato de Victorino de Menezes.

O tráfico interprovincial recebeu um duro golpe e foi praticamente extinto no começo da década de 1880, devido à elevação exorbitante do imposto de entrada de escravos nas províncias do Sudeste (o valor do imposto chegou a ser equivalente ao preço médio de um escravo adulto). Esse fato resultou na interrupção dos negócios de Victorino. Porém, em outubro de 1884, ele ainda empreendeu uma viagem para cobrar créditos em Campinas, quando então foi morto.

\section{"0 crime de Campinas"}

As manchetes nos jornais de Desterro e os depoimentos das testemunhas arroladas no processo crime movido em Campinas nos informam mais detalhes sobre os hábitos de Victorino de Menezes em suas viagens de negócios. Costumava se hospedar no Hotel do Universo, e o 
gerente deste estabelecimento relatou à polícia que conhecia o costume do comerciante de levar grandes quantidades de dinheiro consigo, colocadas em bolsos no interior da roupa (O Despertador, 08/04/1885). Outros campineiros também foram interrogados e afirmaram ser velhos conhecidos do comerciante assassinado, o que ressalta a sua atuação nesse mercado por um longo tempo. ${ }^{5}$ Indiscutivelmente, as declarações das testemunhas, publicadas em parte nos jornais, explicitaram o cotidiano de Victorino e auxiliaram a desvendar o crime.

Estando em Campinas para "arrecadar importantes sommas de dinheiro, de que lhe eram devedores vários fazendeiros e capitalistas dessa praça", ele recebeu a ajuda do agente do Banco Mercantil de Santos, em Campinas. Durante vários dias, o agente José Pinto de Almeida Júnior acompanhou as cobranças de Victorino. Chama-nos a atenção o volume dos negócios, pois somente José Salles havia pago ao comerciante 22 contos de réis. Ao final de alguns dias, tendo recebido quantias de diversos devedores, cujas somas foram calculadas entre 40 e 60 contos de réis, Menezes preparava-se para retornar a Desterro. ${ }^{6}$

Tendo já programado a sua partida, recebeu a visita do agente Almeida Júnior no Hotel do Universo e de lá saiu em sua companhia, segundo depoimentos do funcionário e do gerente do hotel. No dia seguinte, o agente do banco retornou, pagou a conta de Victorino Menezes e declarou que ele já havia embarcado no trem, em direção a São Paulo; solicitou que suas bagagens fossem enviadas para lá. Assim procedeu o gerente do hotel, mesmo tendo estranhado o acontecido. Meses depois, a família do comerciante comunicou o seu desaparecimento à Secretaria de Polícia de São Paulo, e a pedido desses parentes, nos jornais de Desterro foi veiculada uma nota (a que abre este capítulo) expondo o fato e exigindo providências da polícia e da imprensa paulista.

A polícia de Campinas iniciou as diligências, que rapidamente apontaram que Victorino não havia saído da cidade. O aprofundamento das investigações levou ao envolvimento de Almeida Júnior no desaparecimento, e ele passou a ser visto como principal suspeito. Continuando as investigações, a polícia procedeu a uma série de interrogatórios, até dos funcionários da casa do suspeito, que relataram

5 O Despertador, 08/04/1885.

6 A Regeneração, 08/04/1885. 
que o suposto assassino, no dia do crime, havia enviado sua família para a casa de conhecidos e mandado seus funcionários passearem pela cidade. O relato da esposa de Almeida Júnior confirmou o fato, pois tendo ido à casa de José Setubal para visitar uma amiga - a qual estaria doente, segundo informara seu marido -, acabou ali pernoitando.

O depoimento de Indalecio, ex-empregado de Almeida Júnior, reforçou a suspeita. Segundo aquele, o ex-patrão havia dado ordens para que saísse de casa no fim da tarde. Tendo retornado no início da noite, encontrou Almeida Júnior em estado de agitação, e este o mandou consertar o assento da latrina. O funcionário consertou a latrina, verificando que ela havia sido removida; estranhou o desaparecimento de um martelo. As empregadas da casa também ficaram intrigadas com o comportamento do patrão, agitado e nervoso, quando retornaram, à noite. Além disso, repararam que ele havia trocado de calças e que havia pequenas manchas de sangue no chão e em uma das janelas da sala. Elas as lavaram, por ordem de Almeida, que disse ter se ferido. Dias depois, o mau cheiro da latrina, que já incomodava os vizinhos, fez com que José Pinto de Almeida Júnior decidisse fechá-la, destruindo a casinha e tampando o lugar com cal. Em seguida, construiu sobre a antiga latrina um cômodo para os criados.

Sabendo desses detalhes, o delegado de polícia ordenou uma busca na casa e uma escavação no local da antiga latrina. $\mathrm{O}$ auto da busca, publicado nos jornais, informou que a investigação no local resultou na localização de um corpo. Junto a ele, havia também uma calça. Posteriormente, o corpo foi identificado como sendo o de Victorino de Menezes, através do reconhecimento feito por testemunhas, entre elas, Manoel Jorge Graça e Aureliano Monteiro, sócios da vítima. Um anel encontrado com o cadáver também ajudou a determinar sua identidade. O joalheiro Emilio Decourt, de Campinas, reconheceu o anel como peça que havia vendido a Victorino em 1875. A calça foi reconhecida pelos serviçais como sendo a que José Pinto trajava no dia do desaparecimento de Victorino.

A versão reconstituída pelo delegado e divulgada pelos jornais foi a seguinte: no dia em que buscara Victorino no hotel, o agente do banco havia tomado providências para que sua família e criados estivessem fora de casa. Levando o negociante para o local, Almeida o teria matado a golpes de martelo, tendo depois atirado o corpo na latrina da casa, 
mandando tampá-la em seguida, por conta do mau cheiro que exalava. Diante dessa conclusão, Almeida Júnior foi julgado culpado e condenado. Durante todo o mês de abril de 1885, o assassinato foi noticiado pelos periódicos de Desterro, que reproduziram matérias de jornais da Corte e da província de São Paulo, refletindo o grande impacto que esse episódio causou nessas localidades.

Em suma, a cobertura do assassinato de Manoel Antônio Victorino de Menezes revelou uma série de informações sobre suas passagens por Campinas. Testemunhas apontaram seus hábitos e demonstraram conhecimento das práticas do negociante naquela praça. Nomes da rede comercial que montara, apontados em procurações e notas para a venda de escravos, surgiram também nos depoimentos e mesmo no reconhecimento do corpo da vítima, representando a manutenção dessas relações ao longo do tempo.

A análise da trajetória de Victorino, marcada por grandes lacunas e muitas questões, aponta alguns temas importantes para pensarmos e entendermos alguns dos homens que viveram no século XIX. Nascido e criado em uma sociedade escravista, marcada pela propriedade de homens por homens, Menezes ganhava sua vida, pelo menos durante uma época, com a transferência de escravos entre diversas regiões do país. Sua presença em Desterro parece ligada a este negócio, pois chegou à cidade em um momento de expansão do tráfico interno e atuou sempre neste mercado. Sua própria morte liga-se à atividade pois se deslocou ao lugar de seu assassinato para cobrar créditos que lhe eram devidos.

A análise de sua vida em Desterro nos fornece outras informações úteis para a compreensão desta sociedade. Forasteiro com boas condições financeiras, Victorino conseguiu arranjar um lugar para si no mercado local. Suas ligações afetivas e de compadrio se forjaram em localidades fora da vila de Desterro, apesar dos contatos comerciais com seus pares e seus criados e escravos. Como homem de seu tempo, este negociante investiu também na propriedade de terras e na compra de cativos. Em seu testamento, vimos como considerou alguns de seus cativos como herdeiros e como negociou a liberdade de Maria, ao mesmo tempo em que obteve lucros com a venda de escravos alheios.

Como negociante de escravos e habitante de uma pequena capital provincial, a vida de Menezes foi preenchida por questões como a ligação 
com o escravismo e as relações comerciais decorrentes dele. Sem dúvida, seus laços comerciais nos explicitam vários aspectos relevantes sobre o funcionamento do tráfico interno, o que não seria tarefa das mais tranquilas sem a indicação do "mais forte comprador de escravos" a guiar a busca por fontes.

\section{Fontes}

BIBLIOTECA PÚBLICA DO ESTADO DE SANTA CATARINA

Periódicos:

O Despertador. 24/02/1863 - 19/12/1883.

O Conservador. 13/12/1873 - 17/10/1878.

O Conservador. 24/10/1884 - 11/12/1885.

A Regeneração. 19/09/1868 - 13/05/1885.

CARTÓRIO DO 1ำTABELIONATO DE NOTAS DE FLORIANÓPOLIS (Kotzias). Acervo.

Livros de notas de compra e venda de escravos e procurações para a venda:

Livro de notas 27, notas de escravos (1864-1865).

Livros de notas 03, notas de escravos 03 (1865-1867).

Livro de notas 37 (1874-1875).

Livro de notas 44 (1879).

Livro de notas 47 (1879-1880).

Livro de notas 09 (1878-1881).

\section{Referências}

CABRAL Oswaldo R. Nossa Senhora do Desterro. Florianópolis: UFSC, 1972.

CHALHOUB, Sidney. Visões da liberdade: uma história das últimas décadas da escravidão na corte. São Paulo: Cia das Letras, 1990.

DEAN, Warren. Rio Claro: um sistema brasileiro de grande lavoura, 1820-1920.

São Paulo: Paz e Terra, 1977.

FLORENTINO, Manolo. Em costas negras: uma história do tráfico de escravos entre a África e o Rio de Janeiro. São Paulo: Cia. das Letras, 1997. 
FRAGOSO, João; MARTINS, Maria Fernanda. Grandes negociantes e elite política nas últimas décadas da escravidão - 1850-1880. In: FLORENTINO, Manolo; MACHADO, Cacilda. Ensaios sobre a escravidão. (I). Belo Horizonte: UFMG, 2003.

GRAHAM, Richard. Nos tumbeiros mais uma vez? O comércio interprovincial de escravos no Brasil. Afro-Ásia, 27 (2002), p. 142.

HÜBENER, Laura. O comércio da cidade do Desterro no século XIX. Florianópolis: UFSC, 1981.

MACHADO, Maria Helena Pereira Toledo. Crime e escravidão: trabalho, luta e resistência nas lavouras paulistas 1830-1888. São Paulo: Brasiliense, 1987. MELLO, Evaldo Cabral de. O Norte agrário e o Império. 1871-1889. 2. ed. Rio de Janeiro: Topbooks, 1999.

PIAZZA, Walter F. O escravo numa economia minifundiária. São Paulo: Resenha Universitária, 1975.

REIS, João José; SILVA, Eduardo, Negociação e conflito: a resistência negra no Brasil escravista. São Paulo: Cia das Letras, 1989.

SCHEFFER, Rafael da Cunha. Tráfico interprovincial e comerciantes de escravos em Desterro, 1849-1888. Dissertação (Mestrado em História) - Centro de Filosofia e Ceências Humanas/UFSC, Florianópolis, 2006.

SCHWARCZ, Lilia Moritz. Retrato em branco e negro: jornais, escravos e cidadãos em São Paulo no final do século XIX. São Paulo: Cia das Letras, 1987.

SCHWARTZ, Stuart B. Segredos internos: engenhos e escravos na sociedade colonial. São Paulo: Cia das Letras, 1988.

SLENES, Robert W. Na senzala, uma flor: esperanças e recordações na formação da família escrava (Brasil Sudeste, Século XIX). Rio de Janeiro: Nova Fronteira, 1999.

SLENES, Robert W. The Brazilian internal slave trade, 1850-1888: regional economies, slave experience, and the politics of a peculiar market. In: JOHNSON, Walter (Ed.). The Chattel Principle: internal slave trade in the Americas. New Haven: Yale University Press, 2004. 


\section{|| Capítulo 9 ||}

\section{Da escravidão à liberdade na Itha de Santa Catarina}

Henrique Espada Lima

Por muito tempo, ao pensarmos sobre a formação e o povoamento da Ilha de Santa Catarina, nossa atenção ia diretamente para a história dos casais açorianos que chegaram nessas costas a partir de meados do século XVIII. Nessa história, verdadeira epopeia para alguns, frequentemente se esqueceu não apenas das gentes que na Ilha habitavam bem antes disso - portugueses, vicentistas e as populações originais do lugar -, mas também dos outros "viajantes" vindos da África, quase sempre involuntariamente, que, de um modo ou outro, aqui também aportaram. Os próprios migrantes das Ilhas Atlânticas não vieram sós, e entre eles talvez houvesse alguns escravos, como em outros lugares para onde os oriundos da Madeira e dos Açores foram transportados.

Já em fins do século XVIII, de todo modo, os africanos chegaram às centenas, para trabalhar nos empreendimentos que se desenvolviam nessa parte meridional do império português. A pesca da baleia era um exemplo, conduzida a partir das chamadas armações. Elas eram verdadeiras "fábricas", com um grande número de atividades diversificadas - desde a pesca e o corte da baleia, beneficiamento de carne e óleo, armazenamento etc. - que usavam um número bastante expressivo de trabalhadores escravos, chegando facilmente a mais de uma centena. Documentos sobre seu funcionamento demonstram que o uso dos escravos era intenso e que a maior parte deles era de homens vindos da África, direta ou indiretamente trazidos pelo terrível comércio atlântico. 
Assim, não é de admirar que os escravos fossem já uma presença importante e constante na Ilha de Santa Catarina no auge da escravidão brasileira, nas primeiras décadas do século XIX. Na própria cidade de Nossa Senhora do Desterro, eram suficientemente numerosos para ter sua própria Irmandade de Nossa Senhora do Rosário dos Homens Pretos, provavelmente fundada em 1750, e, algumas décadas depois, sua própria igreja. Dessa época, podemos encontrar os primeiros documentos sobre a história da escravidão por aqui. Os livros de registros de batismos, casamentos e mortes, mantidos nas Igrejas e hoje parte dos arquivos eclesiásticos locais, existem para a Ilha de Santa Catarina desde meados do século XVIII. Nesses registros, encontramos testemunhos dessas vidas que deixaram tão poucos traços. Encontramos alguns homens e mulheres que vinham da África e eram batizados, casavam e morriam, recebendo ritos cristãos. Em outros documentos, descobrimos os assentamentos dos impostos pagos quando sua propriedade trocava de mãos por venda, troca, doação ou aluguel. Encontramos também registros de outros momentos das vidas de um punhado deles, como aqueles em que conseguiam suas alforrias, ou as de seus filhos.

\section{A escravidão na Itha de Santa Catarina}

Os registros agregados que conhecemos sobre a população da Ilha mostram a presença constante dos escravos e seus descendentes. Em 1796, ainda no período colonial, um levantamento da população feito a mando do governador João Alberto de Miranda Ribeiro mostra que o número de escravos das quatro freguesias recenseadas da Ilha (Nossa Senhora do Desterro, N. S. Conceição da Lagoa, Ribeirão da Ilha e Nossa Senhora das Necessidades do Santo Antônio) somava 1.995 pessoas, correspondendo a perto de $22 \%$ da população total computada, que chegava a 9.141 pessoas. ${ }^{1} \mathrm{O}$ mesmo registro separava a população considerada "forra", isto é identificada como sendo de libertos da escravidão: esses não somavam mais de 166 pessoas ou 1,8\% da população total. Esse primeiro

1 BIBLIOTECA NACIONAL DO RIO DE JANEIRO. Setor de Manuscritos. Rezumo Geral de Toda a População Pertencente ao Governo da Ilha de Santa Catharina, Formado pelos mappas que derão os officios de cada hum dos Distritos do mesmo Governo. Em 1o de Janeiro de 1796. Original, 2 doc. 130 p. Local: 3, 3, 17. 
recenseamento nos dá certa noção do que era a escravidão e sua distribuição nesse contexto: Desterro contava com quase metade de todos os escravos da Ilha, e a maioria deles era identificada como "pretos" (denominação que se costumava reservar aos escravos africanos e não aos "crioulos" nascidos na terra ou aos "pardos"). O pequeno número de forros também sugere uma população escrava recente, para a qual o acesso à liberdade era ainda bastante restrito.

Meio século depois, a população da Capital (compreendendo as várias freguesias da Ilha) registrada em um censo semelhante apontava um total de 19.945 pessoas, das quais 3.597 eram escravos (18\%). Desta vez, já somavam os libertos 796 “almas", correspondendo a $4 \%$ da população total. ${ }^{2}$ Em 1864, em uma população total de 21.136, os escravos ainda mantinham-se em torno de $18 \%$ da população, enquanto os "pardos e pretos" livres somavam 1.381 , pulando para $6,5 \%$ da população total. ${ }^{3} \mathrm{Em}$ 1872, a mando do governo imperial, foi realizado um amplo recenseamento da população de cada província. Nessa ocasião, a população total da Ilha foi cauculada em 25.709 pessoas, das quais 2.940 eram ainda escravas. Dentro do total da população livre, o censo identificava a população de origem africana livre ou liberta, que já era superior em número aos escravos: 1.650 homens e 1.827 mulheres, num total de 3.477 pessoas. A população identificada como "preta" ou "parda", fossem escravos ou livres, somava um quarto de toda a gente da Ilha neste ano. ${ }^{4}$

Assim, a escravidão ocupava um lugar importante, e a presença africana foi marcante ao longo de todo o século XIX, isto é, no apogeu e na decadência da escravidão. Se é provável que não tenha havido tráfico direto da África para as costas da Ilha de Santa Catarina (ainda que não faltassem comerciantes que desejassem fazê-lo), é verdade que o crescimento da população escrava também se deu pela introdução de africanos importados por outras praças comerciais e não dependeu apenas da "reprodução natural" da população escrava existente. A presença dos africanos era ainda bastante significativa em 1872, período em que a escravidão por aqui começava a perder fôlego. O fim definitivo do tráfico atlântico para o Brasil, depois de 1850, havia promovido um aumento do

2 RELATORIO DO PRESIDENTE DA PROVINCIA DE SANTA CATHARINA, 1860.

3 RELATORIO DO VICE-PRESIDENTE DA PROVINCIA DE SANTA CATHARINA, 1864.

4 INSTITUTO BRASILEIRO DE GEOGRAFIA E ESTATÍSTICA, [1875]. 
comércio interno de escravos, tornando Santa Catarina exportadora de escravos para a grande lavoura cafeeira. Além disso, esse foi um contexto marcado pela chegada constante de imigrantes estrangeiros na província, e a Ilha não escapou disso. Mesmo que os alemães fossem já o maior grupo entre os 884 habitantes estrangeiros registrados na Ilha em 1872, 334 homens e mulheres entre eles, livres ou escravizados, haviam nascido na África, perfazendo 37,8\% de todos os que não haviam nascido no Brasil.

Apesar de não serem perfeitamente confiáveis, os dados agregados nos dão boas pistas sobre a evolução da população de origem africana na Ilha - fossem escravos, forros ou nascidos livres - no período que consideramos aqui, mostrando uma sociedade na qual a escravidão tinha um papel central, mesmo que convivesse largamente com formas diversas de trabalho livre.

Ainda que distinguir as localidades da Ilha opondo a "cidade" urbanizada ao "interior" rural e voltado estritamente à lavoura possa levar a alguns equívocos, não há dúvida que a vida em cada um desses lugares tinha suas peculiaridades, sobretudo para os escravos. Por outro lado, é também verdadeiro que a circulação de pessoas - graças, antes de tudo, à própria circulação dos produtos agrícolas cultivados no interior e do fruto das atividades pesqueiras, distribuídos através da Praça do Mercado no Desterro - garantia que experiências típicas do ambiente urbano, como o trabalho alugado dos escravos, pudesse também reverberar em ambientes menos urbanizados. Somava-se a isso o fato de que Desterro era um porto movimentado do Atlântico Sul, onde também circulavam distintas experiências humanas, livres e escravas. ${ }^{5}$

Aqui é preciso ter claro um elemento central: não existia uma única escravidão, mas muitas. Mesmo em um lugar relativamente pequeno como a Ilha de Santa Catarina, havia muitos modos de ser escravo, assim como havia muitos modos de ser livre ou liberto. A vida de um escravo estava ligada em primeiro lugar às suas condições de cativeiro: suas relações com os proprietários, as formas de manutenção da obediência, os modos de controlar o trabalho, as atividades exercidas, as relações sociais dentro e fora da escravidão. Ter uma profissão urbana, por exemplo, dava acesso a recursos distintos daqueles que se conseguia sendo um trabalhador da lavoura. Isso certamente distinguia os escravos sapateiros, barbeiros,

5 Referências importantes aqui são: CARDOSO, 2008; MALAVOTA, 2000, 2007. 
pedreiros, carpinteiros, ou as costureiras, quitandeiras, cozinheiras, daqueles que não tinham uma profissão definida. Por outro lado, ter a possibilidade de cultivar um pedaço de terra nos finais de semana, criar um porco no quintal ou poder comercializar o produto de uma pescaria, também podia ter um impacto importante nas condições de vida sob a escravidão.

Mesmo na cidade, as situações podiam ser muito diferentes. Entre as escravas que tinham ocupações domésticas, por exemplo, havia aquelas que se dedicavam exclusivamente às tarefas de cuidado da casa e da limpeza, enquanto outras, como as amas de leite ou as lavadeiras, podiam também atuar fora de casa, quando alugadas para outros. Essas modalidades de trabalho alugado podiam ser fonte de renda para os proprietários, mas também eram capazes de gerar algum tipo de compensação financeira para as próprias mulheres que exerciam tais tarefas. Homens e mulheres chamados "escravos ao ganho" - tão comuns no Desterro e em outras cidades brasileiras - tinham prerrogativas semelhantes: colocados na rua para "ganhar" seu sustento mais ou menos autonomamente - como vendedores, carregadores ou em outras ocupações urbanas - permaneciam atrelados aos seus proprietários por fios de espessura variada, sendo obrigados a pagar-lhes "jornal” (parte substancial do seu sustento diário) e podendo até, em muitos casos, morar por conta própria, “vivendo sobre si”.

Por mais contraditório que possa parecer, o acesso a alguma forma de pagamento pelo trabalho era um dos elementos mais importantes que distinguia os escravos uns dos outros. Permanecendo verdade que o que definia a escravidão em termos formais era o fato de que o escravo não era proprietário de si e do seu trabalho, a realidade da escravidão era mais complexa, pois os cativos podiam ganhar algum dinheiro, sem deixar de ser propriedade de alguém. Essa era uma das formas de administração das relações de poder em uma sociedade escravista.

Os senhores de escravos não mantinham a disciplina sobre os homens e mulheres que possuíam exclusivamente pela violência. Ao contrário, ao menos no Brasil escravista, as formas "paternalistas" de dominação eram também frequentemente utilizadas para garantir a obediência e o trabalho. Esse "paternalismo" se encarnava no investimento feito pelos senhores nas relações de dependência dos escravos, em uma ideologia que pregava que as relações entre os senhores 
e seus cativos não era muito diferente daquela que existia dentro das famílias, nas quais a obediência e o respeito seriam a moeda de troca do sustento e da proteção. Com os escravos, essa forma por vezes sutil de dominação, aliada ao uso ou à ameaça do uso da força, era reforçada pela promessa da alforria. ${ }^{6}$

\section{As alforrias na ltha de Santa Catarina}

Durante a maior parte da vigência do sistema escravista no Brasil, a lei ditava que a alforria era uma doação que um proprietário poderia conferir ao seu escravo. As alforrias podiam ser concedidas em qualquer momento da vida: houve filhos de escravos que foram libertados na pia batismal, assim como escravos libertados com mais de 75 anos. Em cada um dos casos, o gesto muitas vezes procurava construir a imagem de benevolência paternal que os senhores se esforçavam em cultivar junto aos cativos. Gestos dessa ordem também serviam para reforçar os vínculos de dependência, mas não apenas isso.

Como toda doação, a alforria podia ser cancelada no caso de "ingratidão" daquele que a recebia (ao menos até 1871, quando essa possibilidade foi revogada). Mas aqui, mais uma vez, a simples leitura da lei não revela as várias possibilidades presentes em torno da alforria e do acesso à liberdade. Para os senhores de escravos, a alforria podia ser usada com incentivo a um bom comportamento e à subordinação. Para os escravos, por outro lado, a alforria também podia ser vista como conquista, fruto da sua própria capacidade de manipular as regras do jogo da escravidão a seu favor. As duas "versões" da história podiam ser perfeitamente verdadeiras.

Para os escravos, a liberdade podia se abrir através de uma relação privilegiada com seus senhores. Na cidade do Desterro, em junho de 1829, a senhora Guiomar da Silva Carvalho deu à sua escrava Maria do Espírito Santo, de 18 anos, a carta de alforria. Nessa, lembra que havia comprado a menina ainda pequena, com sua mãe, uma "negra da Costa" de nome Joana, e dava como razão da libertação "o grande amor que lhe

\footnotetext{
6 Para uma visão detalhada das estratégias de senhores (e escravos) para construir (e contornar) estas relações de dominação pessoal, ver CHALHOUB, 2011.
} 
tenho inspirado da criação". 7 A senhora era viúva de um sargento-mor e, portanto, de alguém com uma posição social importante no lugar - e não tinha filhos ou parentes próximos a quem a doação pudesse de algum modo afetar a herança.

A alforria de Maria mostra a importância que tinha a relação privilegiada com um proprietário. Muito provavelmente, Maria havia sido escrava doméstica de companhia, e a velha senhora desenvolvera por ela um apego que talvez não tivesse por seus outros escravos. Para a senhora, a libertação da escrava teria também outras utilidades: sendo mulher, sem herdeiros, certamente preocupada com a velhice, construir uma nova relação com uma ex-escrava agradecida podia ser um investimento na manutenção de relações de codependência, valiosas no futuro. Maria do Espírito Santo fora libertada na flor da idade e, como descobrimos em outros documentos, libertara-se para casar com outro liberto, de nome Luis de Miranda Ribeiro. Em 1831, o casal recebeu como doação da antiga senhora de Maria uma pequena casa, em um terreno situado perto da Ponte do Vinagre, ao lado da casa da própria Guiomar, no Desterro. A casa era doada com a condição de que o casal não a pudesse vender ou hipotecar, demonstrando que, mesmo após o fim das amarras da relação escravista que ligava as duas mulheres, outros vínculos de dependência e também controle podiam se estabelecer, com vantagens e desvantagens para ambos os lados. ${ }^{8}$ Nesse caso, a manutenção de uma relação de dívida e gratidão acabava reforçando a relação de Maria com sua ex-senhora, mas por outro lado, dava a ela acesso a um patrimônio que um liberto raramente adquiria.

Outro caso que mostra a ambiguidade das relações de interdependência entre senhores e escravos é a alforria de Maria José, dada por sua senhora no Desterro, em agosto de 1851:

Digo eu abaixo assinada Eufrásia Xavier Caldeira, que achando-me separada do meu marido por motivo de sevícia, tratando no Juízo

7 CARTÓRIO DO 1 TABELIONATO DE NOTAS DE FLORIANÓPOLIS (Kotzias). Lançamento do escrito de liberdade ..., 20.06.1829. Livro 4 de notas do 2Ofício do Desterro (1829-1833), fls. 16-16v. Tabelião: Joaquim de Assis e Passos. Florianópolis.

8 CARTÓRIO DO 1ํ TABELIONATO DE NOTAS DE FLORIANÓPOLIS (Kotzias). Escritura de doação que faz D. Guiomar da Silva de Carvalho, de oito braças de chão de frente sitos nesta Cidade, a Maria do Espirito Santo, casada com Luiz de Miranda Ribeiro, 20.06.1832. Livro 4 de notas do $2^{\circ}$ Ofício do Desterro (1829-1833), fls. 162-163. Tabelião: Joaquim de Assis e Passos. Florianópolis. 
Eclesiástico e Municipal das competentes Ações de separação de foro e alimentos, e não tendo podido alimentar-me do necessário, nem pagar a maior parte das despesas que tenho feito há perto de três anos, tanto com as ditas coisas como com o curativo dos escravos Jacinto e Felicianna em que judicialmente me foram estipulados, [...] recebi da minha escrava Maria José a quantia de cento e doze mil réis, em dinheiro para me suprir daquelas despesas, por conta da sua liberdade, que lhe prometo dar, tanto em razão dos seus bons serviços e me ter acompanhado desde a minha separação, como pela lealdade que sempre me guardou repelindo as seduções ilícitas de seu senhor; e por isso lhe confiro pelo presente a sua inteira, completa liberdade, com a única condição de me acompanhar enquanto eu viva for. ${ }^{9}$

Aqui, não há dúvida que uma relação especial ligava a escrava e sua senhora, fruto da situação que lançou Eufrásia em uma condição vulnerável: tendo escapado de uma relação abusiva com o marido, mas sem as condições materiais para garantir sua condição, conta com sua escrava como fonte principal de sustento. Para Maria José, a tragédia de sua senhora era uma oportunidade para ter a alforria, mesmo condicional: conquistado o estado jurídico de liberdade, obrigava-se a "acompanhar" sua senhora enquanto esta vivesse. A cláusula que ligava a alforria à obrigação de "servir" ou "acompanhar" até a morte era bastante comum, ainda que a situação que ligava as duas mulheres presentes nesse documento não fosse. Pode parecer estranho para um leitor de hoje encontrar um reconhecimento de dívida material e moral de uma senhora para com sua escrava e, ao mesmo tempo, uma recompensa aparentemente tão mesquinha: afinal, Maria José não apenas pagou por sua liberdade, mas também comprometeu essa mesma liberdade por um tempo indeterminado com sua antiga senhora. Essas situações-limite faziam parte da experiência de muitos escravos e libertos. A busca e a manutenção da liberdade dependiam muitas vezes de arranjos precários e desiguais, que traduziam as muitas ambiguidades presentes nas relações em uma sociedade na qual a escravidão era considerada legítima e na qual a hierarquia estruturava-se sobre essa desigualdade.

9 CARTÓRIO DO 1 TABELIONATO DE NOTAS DE FLORIANÓPOLIS (Kotzias). Lançamento do escrito de liberdade conferido por Dona Eufrásia Xavier Caldeira, a sua escrava Maria José. 04.08.1851. Livro 12 de Notas do 2O Óício do Desterro (1849-1851), fls. 98. Tabelião João Antonio Lopes Gondim. Florianópolis. 
É claro que, nas suas especificidades, os casos de Maria José e de Maria do Espírito Santo estavam longe de traduzir a maior parte das experiências dos escravos na Ilha de Santa Catarina (ou de qualquer outro lugar) no século XIX. A alforria não era um tipo de "recompensa" pelo bom trabalho, nem uma certeza para a esmagadora maioria dos escravos. Mas ela estava no horizonte de possibilidades da escravidão, e cada um dos lados da relação escravista manipulava essa expectativa a seu modo.

Mais comum que as doações "gratuitas", e ao menos tão importantes quanto as alforrias condicionais, eram as situações nas quais o escravo ou a escrava "comprava" sua liberdade. De um ponto de vista contemporâneo, a "compra" da liberdade parece ser um dos aspectos mais ambíguos da escravidão. Em primeiro lugar, porque o escravo não tinha personalidade jurídica. Em outras palavras, não poderia "possuir" nada, por definição. Mais uma vez, entretanto, a realidade desafiava o conceito: alguns escravos, talvez a maior parte deles (sobretudo em um contexto urbano), tinha acesso a algum tipo de compensação financeira pelo trabalho, sobretudo no século XIX, marcado pela crescente monetarização das relações de trabalho. Mesmo nas grandes fazendas, fazia parte das estratégias de senhores e escravos a possibilidade de estes últimos usarem seus sábados, domingos e dias santos para cultivar seus próprios produtos em áreas não utilizadas para a plantação. Esses produtos não serviam apenas para o autoconsumo, mas entravam em um circuito de trocas e vendas que podiam dar acesso à moeda e, portanto, à possibilidade de alguma economia. Na Ilha de Santa Catarina, isso não era diferente; ao contrário, é provável que a participação nesse mercado informal de produtos e dinheiro estivesse ao alcance de muitos escravos. Um grande número de alforrias que se encontram registradas nos cartórios da Ilha de Santa Catarina por todo o século XIX são, em todo ou em parte, retribuição de algum pagamento em dinheiro.

Esse é o caso da alforria dada por Francisco José Martins e sua mulher Maria Joaquina dos Reis, em março de 1853, ao escravo de nome José, homem definido como "pardo" e sapateiro. Vale a pena ler com atenção as palavras utilizadas para libertá-lo:

porque este pardo nos tenha servido muito bem e lhe temos muita amizade, por havermo-lo criado, e não termos herdeiro forçado, por isto lhe damos d'ora em diante a liberdade, como se livre nascesse, para que goze dos direitos de cidadão, que lhe 
são conferidos pelas nossas leis, com a condição porém de nos acompanhar e viver agregado a nós até o falecimento do último, fazendo-nos a mesada de oito mil réis do seu ofício como até aqui nos tem dado para adjutório de nossas despesas, e para [...] segurança do referido pedimos ambos a Vidal Pedro Moraes que este por nós escrevesse, a qual eu Francisco José assino com o meu punho, e minha mulher por não saber escrever na minha presença rogou ao mesmo Vidal Pedro de Moraes que a seu rogo assinasse na presença das testemunhas $\left[. . . .^{10}\right.$

Na carta de liberdade de José se entrelaçam várias tramas. Trata-se de uma alforria condicional, isto é, não é resultado de uma doação nem do pagamento em dinheiro pelo valor do escravo. Trata-se antes de um tipo de "contrato" através do qual os antigos senhores de José mantinham com ele um vínculo tanto monetário quanto de dependência, pois José tornava-se um "agregado", morando com os patrões e lhes pagando com trabalho não um valor limitado, mas uma "mesada" vitalícia. A carta também nos dá uma boa ideia do que foi a vida de José como escravo: aprendeu a profissão de sapateiro e com ela dava sustento aos seus senhores. Isso significava que talvez trabalhasse em uma oficina, sozinho ou com outros, e tinha suficiente autonomia e responsabilidade para arcar com as despesas fixas previstas na alforria. Seu negócio rendia algum dinheiro e é provável que o arranjo de trabalho que tinha durante a escravidão não fosse radicalmente diferente daquele posterior à alforria. É possível mesmo que, como outros, ele tivesse acumulado algum dinheiro - um pecúlio - com o conhecimento de seus proprietários. Isso lhe dava espaço para negociar os termos de sua liberdade. Ao contrário de outros escravos em condições análogas, José não conseguiu (ou não quis) se desvincular de seus antigos senhores e, por mais que os olhos de hoje olhem sua "liberdade" como excessivamente semelhante à escravidão, ele certamente valorizava e desejava a condição liberta, para além dos elementos de continuidade da sua situação anterior.

Para os escravos que tinham acesso a algum tipo de remuneração, a possibilidade de se afastar dos vínculos que pudessem lembrar a

10 CARTÓRIO DO 1ํ TABELIONATO DE NOTAS DE FLORIANÓPOLIS (Kotzias). Acervo. Lançamento da Escritura de liberdade que abaixo se declara..., 12/03/1853. Livro 14 de notas do $2^{\underline{ }}$ Ofício do Desterro (1852-1853), fls. 29-29v. Tabelião: João Antônio Lopes Gondim, Florianópolis. 
escravidão era muito valiosa. Para isso, era preciso acumular, de modo sistemático, por anos a fio, a quantia necessária para pagar de uma vez só o valor acertado ou arbitrado que poderia resgatar o preço da liberdade. $\mathrm{O}$ acesso à moeda também passava pela economia coletiva (familiar ou de redes de sociabilidade dentro e fora da escravidão) ou por alguma forma de crédito. Em alguns casos, os escravos recorriam ao empréstimo, inclusive de outros senhores que se interessassem pelo seu trabalho.

Na Freguesia do Ribeirão da Ilha, em abril de 1856, um escravo de nome Vicente, "de nação africana", aproveitou o fato de que seu antigo senhor havia morrido e, durante o inventário em que se arrolaram todos os bens do falecido, requereu sua liberdade pelo preço em que foi avaliado, de trezentos e cinquenta mil reis. A viúva Umbelina Perpétua de Andrade, junto com seus nove filhos, concordava com o valor e lhe conferia a liberdade "sem cláusula alguma”, isto é, sem nenhuma outra condição além do pagamento. ${ }^{11}$ Vicente era um escravo "Congo", identificado pela região da África onde nascera ou de onde havia sido traficado. Recorrendo aos registros dos moradores da Freguesia do Ribeirão, feitos 13 anos antes, sabemos que ele deveria quase 53 anos quando se libertou e havia feito parte de um coletivo maior de escravos, todos provavelmente ligados à lavoura do seu proprietário. ${ }^{12}$ Não sabemos ao certo como Vicente conseguiu o dinheiro para sua liberdade, mas podemos supor que boa parte da soma lhe tenha sido emprestada.

$\mathrm{Na}$ cidade do Desterro, em 1879, encontramos um caso no qual um escravo de nome Albino tomou um empréstimo em dinheiro, para o pagamento de sua alforria, de um casal de "pretos" também libertos, Jacinto Gondim e Tereza Callado. Não encontramos a alforria, mas temos o contrato de serviços no qual Albino reconhece a dívida de trezentos e setenta e três mil réis:

11 CARTÓRIO DE NOTAS DO RIBEIRÃO DA ILHA. Escritura de liberdade que fazem Umbelina Perpetua de Andrade e sua filha abaixo assinadas, ao seu escravo Vicente como abaixo se declara, 16/04/1856. Livro 2 do Escrivão do Juiz de Paz da Freguesia do Ribeirão. Escrivão Antônio Caetano Cavalheiro, fls. 15-15v. Florianópolis.

12 Em 1843, seu senhor, Manoel Francisco Xavier, tinha 60 anos, era lavrador e não sabia escrever (sua esposa, Umbelina, tinha 50 anos). Na ocasião, os nove filhos do casal tinham entre 22 e 4 anos de idade e possuíam 8 escravos. O mais velho deles era Vicente, então com 40 anos e o único africano. A mais jovem se chamava Francelina, com apenas 1 ano de idade. Ver: CARTÓRIO DE NOTAS DO RIBEIRÃO DA ILHA. Matrícula dos Moradores da Freguesia do Ribeirão da Ilha, 20 de outubro de 1843. Assinado por Manoel Ferreira, Sub-delegado suplente. fl. 39. Florianópolis. 
[...] pelo que se obriga a pagar ao referido Jacinto Gondim e na sua falta à crioula liberta Thereza Calado com seus bons serviços, obrigando-se pelo prazo de cinco anos a lhe prestar com toda a dedicação, dando-lhe mensalmente a quantia de vinte e quatro mil réis, vestindo ele devedor a sua custa, correndo os alimentos por conta do credor, sendo, entretanto, obrigado a fazer as voltas e trabalhos de casa nas horas vagas e que sejam necessárias aos interesses dos credores, deixando então de ganhar os jornais, levando-se em conta o referido tempo na proporção relativa a vinte e quatro mil réis mensais: obriga-se mais, a vista do que fica estipulado além, lealmente cumprir o referido trato, podendo ser compelido pelos Tribunais e justiça a executa-lo em toda as suas partes. ${ }^{13}$

Aqui, mais uma vez, uma janela importante se abre para entendermos um pouco mais sobre os caminhos para a liberdade em um lugar como Desterro, no século XIX. Por um lado, temos um casal de libertos que, apesar de não saber ler e escrever, possui patrimônio suficiente para bancar um empréstimo a Albino em troca de dinheiro e trabalho. Para eles, era certamente um bom negócio: os pagamentos mensais de Albino somariam, nos cinco anos do contrato, perto de quatro vezes a soma emprestada originalmente e, além da segurança legal do contrato registrado no cartório, Jacinto e Tereza podiam contar com um devedor agradecido pela possibilidade de comprar sua própria liberdade. Albino, por seu lado, havia conseguido escapar da escravidão colocando no "negócio" o único bem que provavelmente possuía: a força dos próprios braços. O acesso ao mercado informal de créditos - do qual o casal de libertos seguramente fazia parte - integrava-o a uma rede de relações sociais para além da escravidão, envolvendo também libertos como ele. $\mathrm{O}$ novo mundo do trabalho "livre" tinha também suas vantagens intrínsecas: ao contrário do trabalho constante que não resultava em ganho para si e não lhe abria outro futuro que o da reprodução de sua própria condição escrava, agora, Albino tinha uma dívida a pagar com seu trabalho, por um prazo determinado. Além disso, seus novos patrões lhe garantiam

13 CARTÓRIO DO 1ำ TABELIONATO DE NOTAS DE FLORIANÓPOLIS (Kotzias). Escritura de locação de serviços que faz o pardo liberto Albino ao preto Jacintho Gondim como abaixo se declara. Livro 47 de Notas do $2^{\circ}$ Ofício do Desterro (1879-1880), escrivão Leonardo Jorge de Campos, 24/12/1879, fls. 70v-71v. 
alimentação e cuidado em caso de doença, uma das grandes preocupações de alguém que não tem outra coisa além da liberdade. As outras vantagens da liberdade são as que ajudam a compreender o enorme esforço que muitos escravos empreendiam para conquistá-la: a possibilidade de viver por si, possuir uma família, escolher as relações de trabalho e mesmo de dependência às quais se submeter, ter acesso à "personalidade jurídica" de uma pessoa livre e não mais ser apenas visto e tratado como propriedade de alguém. $\mathrm{O}$ acesso à rua, a mobilidade espacial, a possibilidade de ser remunerado pelo trabalho e o pertencimento a uma rede de relações sociais, para além da escravidão, eram alguns dos principais elementos que marcavam a vida dos escravos. Também definiam as chances de os escravos adquirirem, em algum momento de suas vidas, a liberdade registrada na carta de alforria. Essa liberdade era, sem a menor sombra de dúvida, profundamente desejada pela esmagadora maioria dos escravos. Era desejada para si, para os seus entes queridos, e objeto de esforços consideráveis, muitas vezes não recompensados.

Falar sobre as muitas frustrações que a escravidão e a impossibilidade de escapar a ela produziram não cabe nesse capítulo. A fuga, a violência, o suicídio, a resignação, foram todas dimensões essenciais da experiência da escravidão para muitos homens e mulheres. Esse pano de fundo de decepção e revolta nos ajuda a compreender melhor o quanto de empenho, planejamento, inteligência, provação e sorte estavam envolvidos na conquista da liberdade. Um exemplo extremo do compromisso dos escravos com a liberdade está contido em dois registros do século XIX que encontramos nos cartórios da Ilha de Santa Catarina. Trata-se de contratos de trabalho feitos pela mesma mulher, Rosa, "parda liberta", em datas e lugares distintos. No primeiro contrato, realizado em 1874 na cidade do Desterro, Rosa - acompanhada e representada pelo Curador Geral de Órfãos, a autoridade que representava os escravos em suas demandas legais - fez um contrato com o capitão José Xavier Pacheco. Este lhe emprestava duzentos mil réis para que pudesse resgatar sua liberdade. Em troca, Rosa se obrigava a cinco anos de "bons serviços domésticos". ${ }^{14}$

14 CARTÓRIO DO 1ํ TABELIONATO DE NOTAS DE FLORIANÓPOLIS (Kotzias). Escritura de locação de serviços que faz a parda Roza a José Xavier Pacheco como abaixo se declara, 30/11/1874. Livro 37 de Notas do 2o Ofício do Desterro (1874-1875). Escrivão: Leonardo Jorge de Campos, fls.3 30-30v. Florianópolis. 
Não encontramos a alforria de Rosa; talvez tenha sido registrada em um livro agora perdido. Pelo seu contrato de "locação de serviços" arranjo de trabalho comum para os libertos, sobretudo depois que foram regulamentados pela Lei do Ventre Livre, em 1871 - sabemos que ela a comprou. Em troca disso, tornou-se empregada no serviço doméstico de outro homem que não havia sido seu senhor, obrigando-se com respeito e obediência. Sabemos também que ela tinha um filho pequeno, provavelmente "ingênuo" (isto é, nascido de ventre livre, depois de 1871). O novo patrão lhe prometia sustento, vestuário e cuidado em caso de doença, para ela e o filho. A história de Rosa não termina aí. Em fevereiro de 1877, ela voltou ao cartório, desta vez, no distrito da Lagoa; vinha fazer novo contrato, em substituição ao anterior. Nesse novo arranjo, encontrou outro patrão, que lhe adiantou o dinheiro para resgatar o contrato anterior. No novo contrato lemos:

\begin{abstract}
[...] não convindo a ambas as partes, a dita parda liberta Rosa e a seu credor dito Manoel Rodrigues de Abreu, a continuarem com o mesmo contrato, resolveram fazer da maneira seguinte: sendo a parda Rosa devedora de dois anos e oito meses de serviço, o credor dispensa os oito meses, ficando somente a devedora obrigada dois anos a contar desta data a dar-lhe o jornal mensal de oito mil réis, não sendo contado neste prazo o tempo que se achar doente, devendo por isso exceder os dois anos que aumentará a proporção do tempo que estiver doente, não sendo ele credor responsável a trato algum, nem a dar-lhe vestuário e sim ela devedora a vestir-se, sustentar-se e tratar-se. ${ }^{15}$
\end{abstract}

Nesse novo contrato, Rosa decidiu dar um passo que a distanciasse ainda mais da experiência da escravidão. Não era mais uma empregada da casa, mas alguém capaz de ganhar seu dinheiro e pagar um "jornal” isto é, uma parte do que conseguia com o produto do seu trabalho - ao seu credor. Rosa agregou algo que mudou suas possibilidades de negociar sua força de trabalho. Suas novas habilidades lhe haviam permitido maior autonomia e a possibilidade de assumir riscos. Ao fim do documento,

15 CARTÓRIO DO 1 TABELIONATO DE NOTAS DE FLORIANÓPOLIS (Kotzias). Escritura de novo contrato que faz a parda liberta de nome Rosa com o seu credor Manoel Rodrigues de Abreu, como abaixo se declara, 15/02/1877. Livro 4 de Notas do Cartório de Paz da Freguesia de Nossa Senhora da Conceição da Lagoa (1876-1879). Escrivão: José Bernardino Damasceno, fls. 9-10v. Florianópolis. 
descobrimos um pouco mais sobre o esforço feito por Rosa para conferir à sua liberdade mais substância: se no primeiro contrato alguém precisou assinar por ela, este novo documento ela assinou com mão firme o próprio nome: Rosa Lima de Bitencourt.

\section{Caminhos da liberdade nas últimas décadas da escravidão}

O século XIX viu o apogeu e a decadência da instituição escravista no Brasil. Em várias partes do mundo ocidental, entre o final do século XVIII e a primeira metade do século seguinte, a escravidão se tornou progressivamente um mal a ser extirpado: o fim do tráfico atlântico de escravos e a abolição da escravidão nas colônias inglesas e francesas foram resultado tanto dos debates políticos e das transformações no campo das convicções políticas, econômicas e morais, quanto da luta por liberdade dos escravos nas colônias e daqueles que combatiam a própria ideia da escravidão nas metrópoles. No Brasil e em outras partes da América, a escravidão demorou a ser ameaçada de fato. Ainda que muitos intelectuais e políticos concordassem que a escravidão teria de ter fim um dia, o argumento do "mal necessário" imperava: o Brasil não podia viver sem a escravidão até que se arranjasse uma solução adequada para lidar com o "elemento servil" e com as necessidades de trabalho da grande lavoura.

O primeiro golpe na escravidão no Brasil se deu através dos tratados com a Inglaterra - país que havia se engajado na destruição do comércio negreiro -, que levaram à proibição legal do tráfico de escravos da África em 1831. Entretanto, não foi fatal: o tráfico ilegal, que durou até 1850, foi responsável pela entrada de centenas de milhares de africanos que, apesar de terem direito à liberdade, viveram como escravos por décadas. Foi apenas em 1871 que uma legislação específica foi aprovada para lidar com a abolição da escravidão no longo prazo. A Lei Rio Branco, também chamada "Lei do Ventre Livre", não apenas tornava livres todas as crianças nascidas de mães escravas após a sua promulgação, como introduzia uma série de novas regras que intervinham fortemente nas relações entre senhores e escravos. Em primeiro lugar, eliminava a velha legislação que tornara a alforria uma doação revogável. Do mesmo modo, possibilitava a compra da alforria pelo escravo como um direito e não mais como "graça" concedida pelos senhores, assim como impedia que as alforrias ficassem condicionadas à prestação de 
serviços por mais de sete anos. A lei buscava administrar um fim lento e ordenado da escravidão, baseado na ideia de que os senhores deveriam ser indenizados pelos escravos que perdessem. Daí uma de suas peças-chave, que previa a alforria com a "cláusula de prestação de serviços" e a exigência de que todo o liberto que conseguisse a alforria devia fazer um contrato de trabalho, sob pena de ser considerado "vadio".

Os passos seguintes são conhecidos: as discussões sobre o fim da escravidão fervilharam nas ruas; os próprios legisladores sentiam isso e, em 1885, a chamada "Lei dos Sexagenários" (Lei Saraiva-Cotegipe) libertou os escravos com mais de 60 anos. Na província de Santa Catarina como um todo, isso significou a libertação de 579 homens e mulheres, 6,9\% dos escravos ainda existentes. ${ }^{16}$ Em 1888, a Abolição deu um fim à escravidão, frustrando tanto as expectativas dos senhores proprietários das dezenas de milhares de escravos que existiam em solo brasileiro, e que ainda detinham muito poder político, quanto dos próprios escravos que desejavam que o fim da escravidão lhes trouxesse algum tipo de compensação pelos séculos de trabalho não remunerado.

Diante de tudo isso, podemos nos perguntar sobre como essas transformações reverberaram por aqui. Em primeiro lugar, não há dúvida que a experiência local repete em grande parte aquilo que se viu em outros lugares. O fim do tráfico teve, como se sabe, um impacto grande sobre os valores dos escravos, tornando a compra da alforria (ao menos em tese) mais difícil. Além disso, a província de Santa Catarina tornou-se também "exportadora" de escravos para o tráfico interno. Mesmo que isso não tenha provocado uma diminuição radical do número de escravos, é comum encontramos, sobretudo a partir do final dos anos 1860, procurações de proprietários para comerciantes que atuavam na venda de escravos em outras praças, como Rio de Janeiro ou Campinas (SP). Isso acarretava a dissolução de famílias e redes de sociabilidade, com um impacto importante sobre as possibilidades de os próprios escravos conseguirem bons arranjos para fora da escravidão. Ainda assim, é preciso notar que o crescimento do tráfico interno não chegou a ter um grande impacto sobre o número total de escravos na Ilha de Santa Catarina, sugerindo que o trabalho escravo continuava a ser importante o suficiente para que os proprietários escolhessem mantê-los.

$16 \quad$ BRASIL, 1885, p. 370. 
O impacto da lei de 1871 não foi pequeno. Como os dados populacionais que citamos demonstram, o número de libertos por alforrias cresce consideravelmente no contexto da lei e sobe ainda mais até as vésperas da Abolição. Não por acaso, a maior parte das alforrias concedidas a partir de 1871 eram condicionadas à retribuição financeira dos senhores, com ou sem a cláusula de prestação de serviços. Daí também a grande quantidade de contratos de locação de serviços, nos quais os libertos registravam suas dívidas em dinheiro com terceiros para a compra da alforria. Nesse contexto, dois novos elementos aparecem no horizonte de possibilidades dos escravos: a intervenção do Estado Imperial nas relações escravistas e a consolidação do movimento abolicionista como ator político importante em prol da libertação do conjunto dos escravos.

A nova interferência estatal atuou em, ao menos, três frentes: primeiro, ao intervir nas relações entre senhores e escravos, minou a autoridade dos primeiros e abriu novas frentes de negociação para os cativos em seu próprio cotidiano; segundo, reconhecendo o direito dos escravos de contestar a vontade senhorial na Justiça, expandiu muito o universo de disputas judiciais que os envolviam e, ao mesmo tempo, ampliou sua possibilidade de sucesso; terceiro, atuando ativamente para a libertação dos escravos através da constituição dos chamados "fundos de emancipação", alimentados pelos impostos e voltados ao pagamento de alforrias com preços arbitrados.

Em todo o lado - e na Ilha de Santa Catarina não foi diferente muitos escravos foram à justiça contestar os direitos de propriedade dos seus senhores. As chamadas "ações de liberdade" tinham as mais distintas alegações: maus tratos, escravização ilegal, falta de cumprimento da promessa de alforria e todo o tipo de ação ilegítima por parte de senhores pouco afeitos a se desfazer dos seus escravos, ou de herdeiros que descumpriam as vontades dos falecidos senhores. ${ }^{17} \mathrm{Um}$ exemplo do tipo de contenda legal em que os escravos se lançavam é o caso da preta liberta Maria Vieira da Silva. Mãe de três meninos, em outubro de 1883, ela compareceu ao Juízo de Órfãos do Desterro contando a sua história: tinha sido escrava do tenente José Vieira da Silva e de sua mulher, Maria do Nascimento da Silva, na Freguesia do Ribeirão. Mais de uma década antes, o casal a havia deixado livre no seu testamento, com a condição

17 Sobre isso, ver, entre outros: GRINBERG, 2008; GRAHAM, 2005; CHALHOUB, 2011. 
seguinte: "Declaramos mais, que fazemos doação dos serviços de uma nossa creoula de nome Maria à Zeferino Lopes e sua mulher Florinda, durante a vida d'estes, depois do que gozará a mesma escrava de sua plena liberdade". ${ }^{18}$ Após a morte dos seus senhores, continuou cumprindo a cláusula de sua alforria e, mais tarde, juntou dinheiro suficiente para sua liberdade. Entretanto, após sua "definitiva” alforria, o último golpe: Zeferino recusou-se a lhe entregar seus filhos, alegando serem eles seus escravos. Foi aí que Maria apelou ao Juiz, alegando a escravização ilegal dos seus filhos. A base de seu argumento, levado adiante por seu representante legal, Laurentino José do Carmo, era que tanto ela quanto seus filhos haviam sido ilegitimamente escravizados, pois os primeiros proprietários de Maria haviam doado seu trabalho, mas nunca haviam passado em cartório a propriedade da escrava para Zeferino e sua mulher. Portanto, a cláusula condicional da liberdade deixara de ter efeito quando morreram. Após sua morte, tudo o que havia acontecido, a matrícula de Maria e dos seus filhos como escravos em 1871 por Zeferino, todo o trabalho cativo dela e dos filhos desde então não era outra coisas senão "o crime de reduzir à escravidão uma pessoa livre". ${ }^{19}$ O processo de Maria Vieira da Silva para recuperar seus filhos e ver reconhecida a sua liberdade foi à corte de apelação - o Tribunal da Relação em Porto Alegre. Não sabemos exatamente o resultado da súplica legal de Maria ao Juizado de Órfãos, mas os seus argumentos calavam fundo nas convicções legalistas de alguns homens que operavam a Justiça nas últimas décadas da escravidão. Advogados e mesmo juízes simpáticos à causa abolicionista acabavam por dar a muitos escravos a possibilidade de conseguir a liberdade através de caminhos legais antes inexistentes. É possível que essa tenha sido a sorte de Maria e seus filhos.

Situações como essa colocavam diretamente em xeque a instituição escravista como um todo, simultaneamente atacada pela audácia e perspicácia dos escravos, além do apoio e o conhecimento dos meandros e ambiguidades da legislação por parte dos advogados e juízes. Soma-se a

18 MUSEU JUDICIÁRIO DE SANTA CATARINA. Inventário de Maria Vieira da Silva. Juízo de Órfãos e ausentes. Cidade do Desterro. $1^{\text {a }}$ Vara da Família, caixa ano 1883. Pesquisador: Patrícia R. Geremias.

19 A Lei Rio Branco (Lei no 2040, de 28/09/1871, também conhecida como Lei do Ventre Livre) estabelecia em seu artigo 8o a execução de uma "matrícula especial de todos os escravos existentes no Império". 
isso a própria atuação das chamadas Juntas de Classificação de Escravos, que, operando nos municípios juntamente com os Juízes de Órfãos e recebendo financiamento de várias fontes (taxas, emolumentos e loterias, criados com este fim pelos governos imperial, provincial e municipal, e doações de particulares), atuavam igualmente para desestabilizar (ao menos em parte) a lógica tradicional de concessão das alforrias. As juntas recebiam as solicitações dos escravos que desejavam sua liberdade, classificavam essas solicitações de acordo com critérios de prioridade previamente estabelecidos, arbitravam os preços dos escravos de acordo com os valores praticados no mercado (muitas vezes em disputa com os proprietários que desejavam influenciar o preço das avaliações) e, finalmente, alforriavam os escravos em cerimônias públicas, convocadas pelo Juiz de Órfãos e com a presença obrigatória dos antigos proprietários, em uma sessão da Câmara de Vereadores. Lá, os escravos recebiam suas cartas de liberdade, não por acaso, da mão de seus próprios ex-senhores.

Até 1883, de acordo com o Relatório do Ministério de Agricultura do Império, os resultados acumulados dos Fundos de Emancipação nas Províncias apontaram para Santa Catarina um total de 293 escravos alforriados. ${ }^{20}$ Destes, 64 provinham do Desterro, para um total (naquele momento) de 1.125 escravos. Esses números crescem até 1887, quando as atividades das Juntas de Emancipação parecem entrar em declínio. Pode não ser de fato um grande número, mas na Ilha de Santa Catarina - como em outros lugares - o Fundo de Emancipação teve menos um impacto direto sobre o fim da escravidão do que sobre as expectativas gerais de senhores e escravos sobre a proximidade desse fim. ${ }^{21}$ Nos seus últimos anos, a instituição foi acompanhada da crescente convicção de que a Abolição era necessária e irremediável.

É certo que o cumprimento das leis de 1871 e 1885 levaria necessariamente à extinção definitiva da escravidão em um prazo largo, mais ou menos determinado, cumprido sob o signo da abolição gradual, pacífica e com a indenização dos proprietários. Mas qualquer consenso que possa ter existido em torno dessa versão da história foi se tornando cada vez menor durante a década de 1880. O movimento abolicionista ganhou importância progressivamente, em suas várias versões.

\footnotetext{
20 Dados retirados de BRASIL, 1885 apud DAUWE, 2004, p. 30.

21 Ibidem.
} 
Diferente de lugares como a Província de São Paulo ou o Rio de Janeiro, na Ilha de Santa Catarina, o abolicionismo parece chegar tardiamente e sem os tons de radicalidade e combatividade que adquiriu em outros contextos urbanos..$^{22}$ Certamente as convicções abolicionistas já circulavam por aqui, em lugares como a loja maçônica A Regeneração Catharinense e em outros circuitos e associações. Há notícias de um Club Abolicionista operando nos anos de 1870, mas não há muitas indicações sobre isso. Em 1884, entretanto, uma alforria registrada no Cartório de Notas do Desterro contém uma observação interessante:

Pela presente concedo plena e inteira liberdade a minha escrava de nome Maria da Anunciação de cor parda, de quatorze anos de idade, mais ou menos, matriculada n'Alfândega desta Cidade [...], para que dela goze como que se de ventre livre nascessem e declaro que o motivo desta minha resolução não é só o amor e criação que tenho à mesma, como faço por inaugurar-se hoje o club "Abolicionista" desta Capital.

Desterro, 13 de Abril de 1884. Maria Constancia da Silveira Cardozo [...]. Desterro 14 de Abril de 1884. ${ }^{23}$

$\mathrm{Na}$ verdade, parece que a atividade abolicionista floresceu de fato por aqui em meados da década de 1880, agrupando profissionais liberais, advogados, comerciantes como Raulino Horn, Germano Wendhausen e outros jovens aspirantes da política local. O Clube Abolicionista foi fundado em 1884, nas dependências do Clube 12 de Agosto, e um jornal - O Abolicionista - também passou a circular no mesmo ano por um breve período. As atividades mais vistosas do Clube Abolicionista (e do abolicionismo em geral no Desterro) foram as arrecadações para a compra de alforrias em festas e bazares, bem como a sensibilização de parte da classe de proprietários de escravos, que parecem ter aderido tardiamente à "causa", talvez movidos menos por suas convicções do que por uma leitura mais ou menos acurada do novo sentimento geral de reprovação da escravidão. Um pouco desse cinismo foi detectado pelos

\footnotetext{
22 Ver, por exemplo, MACHADO, 2010; MENDONÇA, 1999.

23 CARTÓRIO DO 1ำTABELIONATO DE NOTAS DE FLORIANÓPOLIS (Kotzias). 2o Oficio do Desterro. Livro 57 (1884) Tabelião: Leonardo Jorge de Campos, fls. 19v. Florianópolis.
} 
próprios contemporâneos, como sugere a nota ácida publicada no jornal O Conservador, do Desterro, em outubro de 1884:

Conhecemos abolicionistas entusiastas, grandes propagandistas, conservando ainda seus semelhantes no cativeiro, e outros que, calculam o tempo que pode durar a escravidão no Brasil, alforriam seus escravos com a condição de continuar a servi-los por esse prazo, assim não são nem forros nem cativos. No entanto fazem gemer os prelos para constar sua filantropia, mas o cativeiro está lá escondido nas entrelinhas dos jornais e nas reticências dos bombásticos discursos. ${ }^{24}$

A nota de jornal era um golpe e tanto no contexto da arena política do fim do Império - que opunha conservadores e liberais, republicanos e monarquistas, abolicionistas convictos e de ocasião etc. - mas não perdia o alvo, como sugere uma das muitas alforrias encontradas nos registros cartoriais da Ilha de Santa Catarina nos últimos anos da escravidão:

Honra e Gloria Ao Club Abolicionista. Declaro eu abaixo assinada que sendo senhora e possuidora de uma escrava de nome Lucia, de cor parda, averbada n'Alfândega desta Cidade sob n ${ }^{\circ} 159$, concedo liberdade à mesma escrava, com a condição de me servir durante três anos a contar desta data. Desterro 11 de Outubro de 1884. Maria Augusta Brandt [...]. ${ }^{25}$

A despeito da saudação ao "club Abolicionista", a alforria que Maria Brandt concede à sua escrava Lucia não chega exatamente a ser um exemplo comovente de desprendimento ou de compromisso inequívoco com a causa da Abolição. É provável que não estejamos muito distantes da verdade ao afirmarmos que uma atitude relativamente cínica com relação ao fim da escravidão era bastante comum, inclusive entre as hostes abolicionistas. É interessante notar que vários abolicionistas importantes no Desterro podem ser encontrados entre os contratantes dos serviços dos libertos, para quem emprestavam dinheiro.

24 O CONSERVADOR. Desterro. Anno I, 21 de outubro de 1884. nำ 41. Biblioteca Pública do Estado de Santa Catarina.

25 CARTÓRIO DO 1ำ TABELIONATO DE NOTAS DE FLORIANÓPOLIS (Kotzias). 2o Oficio do Desterro, Livro 58 (1884-1885), fls. 11v, Tabelião Leonardo Jorge de Campos. Florianópolis. 
Esse é o caso de Idalino, "crioulo liberto" que pediu emprestado a Germano Wendhausen a "quantia de duzentos mil réis para pagá-los no prazo de quatro anos [...], servindo com todo respeito assim e carinho, obedecendo-lhe e a sua família, a fazer o serviço que ele e sua família ordenar e finalmente fazer o possível de não deixar de cumprir o presente contrato". ${ }^{26}$ Em troca, Wendhausen comprometia-se com a roupa para o serviço doméstico, alimentação e cuidado no caso de doença (desde que "não excedam quinze dias"). A liberdade poderia ser um "negócio" lucrativo também para alguns abolicionistas: uma forma de recrutamento de trabalhadores relativamente dóceis e agradecidos, pelo menos.

Lúcia e Idalino não estavam sozinhos na sua nova situação: descobriram que a liberdade, mesmo com honras e glórias ao Clube Abolicionista, não seria uma conquista tão simples. Ao contrário, o mundo da "liberdade" podia trazer muitas semelhanças com a escravidão, assim como muitas armadilhas e desafios que frustrariam em muito as expectativas dos que dela saíam de uma vez por todas.

\section{Considerações finais}

Em agosto de 1886, entraram no $1^{\circ}$ Cartório de Notas do Desterro o "pardo liberto" José acompanhado de Francisco Duarte da Silva. Ambos registraram um contrato de locação de serviços, pelo qual José reconhecia a dívida de trezentos mil réis que tinha com Francisco, contraída para “obter sua plena liberdade". Obrigava-se a "pagar com seus bons serviços pelo tempo de sete anos a contar da presente data, fazendo todo o serviço que lhe for ordenado pelo locatário e sua família, [...] obedecendo-o e respeitando-o como se escravo fosse, bem como obriga-se a acompanhar o locatário e sua família para qualquer lugar que tenha d'ir". ${ }^{27}$

O arranjo de liberdade e de trabalho em que se engajou José quando conseguiu sua alforria nos mostra muito sobre a "nova" vida dos

26 CARTÓRIO DO 1- TABELIONATO DE NOTAS DE FLORIANÓPOLIS (Kotzias). 2o Ofício do Desterro. Livro 60 (1886), fls. 34-34v. Tabelião Leonardo Jorge de Campos. Florianópolis.

27 CARTÓRIO DO 1ํㅡABELIONATO DE NOTAS DE FLORIANÓPOLIS (Kotzias). 1ํo Ofício de Notas do Desterro. Escritura de locação de serviços que faz o pardo liberto José a Francisco Duarte Silva... 21.08.1886. Livro 11 de Notas de Escravos (1886-1887), fls. 3v-4. Tabelião: Francisco Xavier da Câmara Junior. 
ex-escravos. Em primeiro lugar (mas é claro, ele não poderia saber disso), sua dívida o comprometia para bem depois da Abolição. Não sabemos se cumpriu seu compromisso depois de 1888, já que a "prestação de serviços" a que se obrigava não era uma condição de sua alforria, mas um contrato com um terceiro. De todo modo, seu arranjo de trabalho revelava outras coisas importantes sobre o mundo da "liberdade" e sobre as expectativas que os novos patrões tinham dos libertos: que trabalhassem, obedecessem e deles dependessem como se nunca tivessem deixado de ser escravos. Esses eram alguns dos desafios que os ex-escravos já conheciam: conseguir a liberdade para si, e inventar um significado para essa liberdade foi uma tarefa que gerações de libertos e pessoas livres de origem africana enfrentaram muito antes da Abolição. O mundo da moderna "liberdade" havia sido construído, lentamente, ao longo do século XIX: o trabalho forçado seria substituído pelo trabalho "contratado", do mercado "livre" de trabalho, no qual cada um vendia "livremente" o seu trabalho, pelo preço que alguém se dispusesse pagar. Mas como sabemos, o mundo da "liberdade de trabalho" não era tão simples nem tão justo e correto quanto a imagem que se poderia construir dele.

Em primeiro lugar, os ex-escravos não estavam sozinhos na busca por trabalho e melhores condições de vida. Se tomarmos o mundo do trabalho doméstico e dos serviços urbanos - que eram, sem dúvida, boa parte do universo do "mercado de trabalho" que os libertos tinham pela frente - vemos que era também disputado por um contingente de livres pobres e um número crescente de imigrantes que chegavam ao Desterro e concorriam por essas ocupações, mesmo que fossem bastante precárias.

Assim, em 1883, por exemplo, estabeleceu-se na capital uma lei que ordenava que todos os empregados domésticos, livres ou escravos, deveriam ser cadastrados pela polícia. Dos registros que encontramos do pagamento dos impostos das cadernetas dos empregados, descobrimos, ao lado de escravas e escravos, mulheres livres com nomes como Joaquina Rita da Conceição e Tomásia Rosa de Jesus, que bem poderiam ser pretas e pardas livres ou libertas, que iam à Câmara pagar seus cinco mil réis do imposto de registro, e ao lado de outras mulheres com sobrenomes germânicos como Bükler ou Bartells. Do mesmo modo, no registro de cocheiros e condutores do Desterro, que se produziu em 1881, encontramos trabalhadores como o preto Izidro José da Silva, nascido 
no Desterro e com vinte e cinco anos, que dividia espaço como cocheiro nas ruas da cidade com outros trabalhadores, como Domingos Ferrari ou Charles Panten, que tinham vindo de lugares tão distantes quanto a Áustria ou a França. ${ }^{28}$

O trabalho duro, um mercado de empregos restrito, oportunidades escassas e as barreiras do preconceito e do racismo marcaram muito a experiência dos libertos e afrodescendentes livres, antes e depois da Abolição. As raras oportunidades de acesso a arranjos de trabalho justos, educação e aprendizado de uma profissão, propriedade e ascensão social foram objeto de luta e de difícil conquista. Os homens e mulheres que protagonizaram essas lutas e enfrentaram esses desafios da liberdade foram sujeitos de suas próprias histórias, mesmo quando não tinham um final feliz. Muitas delas ainda estão guardadas entre as páginas de documentos empoeirados, hoje depositados nos arquivos e bibliotecas, esperando para serem contadas.

\section{Fontes}

BIBLIOTECA NACIONAL DO RIO DE JANEIRO. Setor de Manuscritos.

Rezumo Geral de Toda a População Pertencente ao Governo da Ilha de Santa Catharina, Formado pelos mappas que derão os officios de cada hum dos Distritos do mesmo Governo. Em 1o de Janeiro de 1796. Original, 2 doc. 130 p. Local: 3, 3, 17.

\section{BIBLIOTECA PÚBLICA DO ESTADO DE SANTA CATARINA}

O Conservador. n. 41. Ano I, 21 de outubro de 1884.

\section{CARTÓRIO DO 1 TABELIONATO DE NOTAS DE FLORIANÓPOLIS (Kotzias)}

Lançamento do escrito de liberdade ..., 20.06.1829. Livro 4 de notas do $2^{\circ}$ Ofício do Desterro (1829-1833), fls. 16-16v. Tabelião: Joaquim de Assis e Passos. Florianópolis.

Escritura de doação que faz D. Guiomar da Silva de Carvalho, de oito braças de chão de frente sitos nesta Cidade, a Maria do Espirito Santo, casada com Luiz de Miranda Ribeiro, 20/06/1832. Livro 4 de notas do 2o Ofício do Desterro (18291833), fls. 162-163. Tabelião: Joaquim de Assis e Passos. Florianópolis.

28 Há no Arquivo Histórico Municipal de Florianópolis um Registro de títulos de cocheiros e condutores de veículos desta Cidade, aberto em agosto de 1881. Nele estão contidos somente cinco registros, entre os quais os do preto Izidro, do austríaco Ferrari e do francês Panten. 
Escritura de novo contrato que faz a parda liberta de nome Rosa com o seu credor Manoel Rodrigues de Abreu, como abaixo se declara, 15/02/1877, Livro 4 de Notas do Cartório de Paz da Freguesia de Nossa Senhora da Conceição da Lagoa (1876-1879). Escrivão: José Bernardino Damasceno, fls. 9-10v. Florianópolis.

Escritura de locação de serviços que faz o pardo liberto José a Francisco Duarte Silva. 21.08.1886. Livro 11 de Notas de Escravos (1886-1887), fls. 3v-4, 1o Ofício de Notas do Desterro. Tabelião Francisco Xavier da Câmara Junior. Florianópolis.

Escritura de locação de serviços que faz a parda Roza a José Xavier Pacheco como abaixo se declara, 30/11/1874, Livro 37 de Notas do 2o Ofício do Desterro (1874-1875). Escrivão: Leonardo Jorge de Campos, fls.3 30-30v. Florianópolis.

Escritura de locação de serviços que faz o pardo liberto Albino ao preto Jacintho Gondim como abaixo se declara, Livro 47 de Notas do 2o Ofício do Desterro (1879-1880). Escrivão: Leonardo Jorge de Campos, 24/12/1879, fls. 70v-71v. Florianópolis.

2o Ofício do Desterro. Livro 57 (1884) Tabelião: Leonardo Jorge de Campos, fls. 19v. Florianópolis.

2o Ofício do Desterro. Livro 58 (1884-1885), fls. 11v. Tabelião: Leonardo Jorge de Campos. Florianópolis.

2o Ofício do Desterro. Livro 60 (1886), fls. 34-34v. Tabelião: Leonardo Jorge de Campos. Florianópolis.

\section{CARTÓRIO DE NOTAS DO RIBEIRÃO DA ILHA.}

Escritura de liberdade que fazem Umbelina Perpetua de Andrade e sua filha abaixo assinadas, ao seu escravo Vicente como abaixo se declara, 16.04.1856. Livro 2 do Escrivão do Juiz de Paz da Freguesia do Ribeirão, Escrivão Antônio Caetano Cavalheiro, fls. 15-15v. Florianópolis.

Matrícula dos Moradores da Freguesia do Ribeirão da Ilha, 20 de outubro de 1843. Assinado por Manoel Ferreira, Sub-delegado suplente. fl. 39. Florianópolis.

MUSEU JUDICIÁRIO DE SANTA CATARINA. Inventário de Maria Vieira da Silva. Juízo de Órfãos e ausentes. Cidade do Desterro. 1므 Vara da Família, caixa ano 1883. 
BRASIL. Ministério da Agricultura. Ministro João Ferreira de Moura.

Relatorio do Anno de 1884 apresentado á Assembléa Geral da 1ํㅗㅇ Sessão da 19a Legislatura. Publicado em 1885.

CARDOSO, Paulino J. F. Negros em Desterro: experiências das populações de origem africana em Florianópolis. Séc. XIX. Itajaí: Casa Aberta, 2008.

CHALHOUB, Sidney. Visões da liberdade: uma história das últimas décadas da escravidão na Corte. São Paulo: Companhia das Letras, 2011. (edição de bolso). DAUWE, Fabiano. A libertação gradual e a saída viável: os múltiplos sentidos da liberdade pelo fundo de emancipação de escravos. Dissertação (Mestrado em História). UFF, Niterói, 2004.

GRINBERG, Keila. Liberata. A lei da ambiguidade: as ações de liberdade da Corte de Apelação do Rio de Janeiro no século XIX. Rio de Janeiro: Centro Edelstein de Pesquisas Sociais, 2008.

GRAHAM, Sandra L. Caetana diz não: história de mulheres da sociedade escravista brasileira. São Paulo: Companhia das Letras, 2005.

INSTITUTO BRASILEIRO DE GEOGRAFIA E ESTATÍSTICA. Gerência de Biblioteca e Acervos Especiais. Recenseamento Geral do Brazil de 1872. v. II Provincia de Santa Catharina. s/d. CD-ROM.

MACHADO, Maria Helena P. T. O plano e o pânico: os movimentos sociais na década da abolição. 2. ed, São Paulo: EDUSP, 2010.

MALAVOTA, Claudia Mortari. Os homens pretos do Desterro: um estudo sobre a Irmandade de Nossa do Rosário (1841-1860). Dissertação (Mestrado em História). PUC/RS, Porto Alegre, 2000.

. Os africanos de uma vila portuária do sul do Brasil: criando vínculos parentais e reinventando identidades. Desterro, 1788/1850. Tese (Doutorado em História) - PUC/RS, Porto Alegre, 2007.

MAMIGONIAN, Beatriz G. Africanos em Santa Catarina: escravidão e identidade étnica (1750-1850). In: FRAGOSO, João Luis Ribeiro; FLORENTINO, Manolo G.; SAMPAIO, Antonio Carlos Jucá; CAMPOS, Adriana. (Org.). Nas rotas do império: eixos mercantis, tráfico e relações sociais no mundo português. Vitória; Lisboa; Brasília: Ed. UFES; Instituto de Investigações Científicas Tropicais; CNPq, 2006, p. 609-644. 
MATTOS, Hebe Maria. Das cores do silêncio: os significados da liberdade no Sudeste escravista, Brasil século XIX. Rio de Janeiro: Nova Fronteira, 1998. MENDONÇA, Joseli. Entre a mão e os anéis. A lei dos sexagenários e os caminhos da Abolição no Brasil. Campinas: Ed. Unicamp, 1999.

. Cenas da Abolição: escravos e senhores no Parlamento e na Justiça. São

Paulo: Ed. Fundação Perseu Abramo, 2001.

RELATORIO DO PRESIDENTE DA PROVINCIA DE SANTA CATHARINA, Francisco Carlos Araujo Brusque, apresentado à Assembleia Provincial na $1^{\underline{a}}$ Sessão da 10ª Legislatura. Rio de Janeiro: Typographia do Correio Mercantil, 1860.

RELATORIO DO VICE-PRESIDENTE DA PROVINCIA DE SANTA CATHARINA, o commendador Francisco José d'Oliveira, apresentado à Assembleia Legislativa Provincial na 1aㅗ Sessão da 12a Legislatura. Santa Catharina. Typographia Catharinense de F. V. Avila, 1864.

SLENES, Robert. Na senzala, uma flor: esperanças e recordações na formação da família escrava. Brasil, Sudeste, Século XIX. Rio de Janeiro: Nova Fronteira, 1999. 


\section{|| Capítulo 10 ||}

\section{Cruz e Sousa: de Desterro para o panteão da poesia simbolista}

Elizabete Maria Espíndola

João da Cruz e Sousa nasceu em Desterro, atual Florianópolis, em 24 de novembro de 1861. Filho de Guilherme de Sousa, escravo com o ofício de mestre pedreiro, sua mãe Carolina Eva da Conceição, era lavadeira e liberta. O sobrenome Sousa pertencia ao Marechal Guilherme Xavier de Sousa, de quem seu pai fora escravo e por ele alforriado em 1864, antes de partir para a Guerra do Paraguai - época em que João Cruz e Sousa contava três anos de idade. Cruz e Sousa nasceu livre, pois sua mãe era liberta; morava com os pais e o irmão mais novo, Norberto de Sousa, em uma pequena casa no bairro da Praia de Fora, em Desterro. O fato de possuírem um ofício possibilitou que Guilherme e Carolina Eva garantissem certa autonomia e a unidade da família.

Quanto à sua formação letrada, Cruz e Sousa iniciou seus estudos em 1869. Em 1872 estava matriculado juntamente com o irmão, no Colégio da Conceição (região da atual Praça Getúlio Vargas), dirigido por Dona Rozalina Paes Leme. Mais tarde, os irmãos ingressaram no Ateneu Provincial, uma das principais escolas preparatórias para aqueles que desejassem levar adiante seus estudos na capital do Império. Mesmo mantida com o auxilio do poder público, não era gratuita e recebia alunos de diferentes regiões. Logo, nos perguntamos como os filhos de um exescravo com poucos recursos puderam frequentar um colégio particular, destinado principalmente aos filhos da elite local?

A educação pública e privada voltada para os escravos, libertos ou livres e seus descendentes é um capítulo à parte na história da educação 
brasileira. Eliane Peres, em seu trabalho sobre os cursos noturnos da Biblioteca Pública Pelotense (Pelotas, RS), procurou localizar a presença de negros nestes cursos. Segundo a autora, podiam frequentar as aulas, desde que livres ou libertos. ${ }^{1}$ Os livros de matrícula registravam os ofícios daqueles que frequentavam os cursos; as profissões estavam ligadas especificamente a trabalhos manuais e domésticos. Os alunos eram, na maioria, criados, artistas, marceneiros, carpinteiros, sapateiros, alfaiates, caixeiros, chapeleiros e ferreiros. Na cidade de Pelotas, os negros escravos, livres e libertos, como os brancos pobres, ocupavam-se das atividades domésticas e da produção de bens e de serviços; imigrantes pobres também viviam dessas atividades, além de muitos deles atuarem no comércio. Ainda segundo a pesquisadora, na visão das elites pelotenses, além da instrução primária, era preciso oferecer a educação moral a estes indivíduos. Justamente porque o objetivo era manter a ordem, disciplinar e incutir preceitos de moralidade e civilidade. $^{2}$

Em Desterro, segundo o artigo 13 do regulamento do Ateneu Provincial, era permitido ao presidente mandar admitir no instituto, a custa dos cofres provinciais, quatro menores como pensionistas, seis como meio-pensionistas e dez como externos, desde que lhes fosse reconhecida a inteligência e viessem de família honesta, com preferência por filhos de empregados públicos da província que tivessem se distinguido pelo bom desempenho no cargo. ${ }^{3}$ Assim, mesmo com poucos recursos, foi neste requerimento que se baseou Guilherme de Sousa e, com a ajuda de alguns professores do Colégio da Conceição, solicitou ao presidente provincial a matrícula de seus dois filhos. O requerimento foi deferido em 30 de junho de 1874. Aos olhos de hoje, tal ato pode parecer sem relevância, entretanto, o que o tornou importante foi o fato de que em Desterro do século XIX, as oportunidades eram escassas e restritas aos portugueses e seus descendentes, a atitude de Guilherme de Sousa possibilitou ampliar o espaço de autonomia necessário para viabilizar projetos e sonhos, ou simplesmente garantir a sobrevivência futura de seus filhos.

\footnotetext{
PERES, 2002.

2 Ibidem, p. 85.

3 ARQUIVO PÚBLICO DO ESTADO DE SANTA CATARINA. Correspondência da Instituição Pública ao Presidente da Província. Oficio de 17 de junho de 1874.
} 
Em ambos os casos, Pelotas e Desterro, percebemos que a preocupação com a moralidade e com a honestidade dos indivíduos se fazia presente, sem a preocupação, por parte das elites, de promover uma ruptura com os padrões de uma sociedade hierarquizada e excludente; contudo, em pequenas brechas de oportunidade foi que se possibilitou a ampliação dos espaços de autonomia para libertos e livres.

Quanto ao desempenho de Cruz e Sousa e Norberto em Desterro, segundo o jornal $O$ Conservador - responsável pela publicação das avaliações de aproveitamento dos alunos do Ateneu - ambos obtiveram rendimento acima de satisfatório. Frequentaram as aulas com dedicação e assiduidade, cursando português, francês, inglês, geografia e matemática, até o ano de 1877, quando deixaram de frequentar as aulas. Por falta de uma documentação mais precisa, não podemos afirmar se ambos concluíram os estudos. Em 1881, Cruz e Sousa já contava 20 anos, e o encontramos trabalhando como caixeiro cobrador de uma firma de exportação de carne para Montevidéu. Nas horas vagas, dava aulas particulares para completar sua renda. Quanto a seu irmão Norberto, alguns memorialistas da cidade apontam que teria seguido o ofício do pai; outros afirmam que exerceu o ofício de canoeiro, trabalhando no transporte de mercadorias no porto. Desde cedo, Cruz e Sousa buscou mobilidade nesta sociedade escravista e estratificada; muitas foram suas estratégias, entre elas, o teatro, com atividades amadoras, desenvolvidas em pequenas sociedades dramáticas de Desterro. Nos jornais do final do século XIX, percebe-se o aparecimento de um número significativo de anúncios sobre estas sociedades, bem como notícias sobre a passagem de companhias teatrais profissionais, provenientes de outras Províncias.

Para alguns memorialistas que escrevem sobre Desterro, a cidade possuía uma vida cultural inexpressiva, sendo o seu único espaço de espetáculos o palco do Teatro Santa Izabel, espaço muito mal conservado, faltando-lhe desde iluminação apropriada até cenários e cortinas. ${ }^{4}$ Iaponan Soares, em estudo sobre Cruz e Sousa, destacou a opinião de um cronista da época, que reclamava providências e melhorias para o teatro, alegando que "no palco, custa-se a conhecer os atores, o que só conseguem os que estão mais distantes ou pela voz ou à custa de binóculos; esta

\footnotetext{
4 Sobre os aspectos urbanos, socioeconômicos e culturais de Desterro/Florianópolis, ver estudos de CABRAL, 1977.
} 
situação favorecia a ocorrência de pequenos furtos causando desconforto e perturbando o andamento dos espetáculos". ${ }^{5}$ Abelardo Montenegro, um dos principais biógrafos de Cruz e Sousa afirmou em seu estudo que "a vida social naquela época, de quase nenhum brilho se revestia. O público jazia em permanentes férias a respeito de entretenimentos. $\mathrm{O}$ mundo elegante aproveitava, furiosamente, as oportunidades que se ofereciam. Em geral, a nota do dia davam-nas às Companhias Teatrais". ${ }^{6} \mathrm{O}$ autor segue afirmando que a vida social em Desterro era marcada pela monotonia, quebrada pela passagem de algumas companhias teatrais, pelas touradas, pelos circos e pela devoção ao Senhor Bom Jesus, em oratórios nas residências. Entretanto, uma leitura mais atenta dos jornais da época, apontou a existência de uma quantidade variada de sociedades dramáticas amadoras, que se apresentavam em locais improvisados, como galpões e armazéns, e não somente no palco do Santa Izabel. Possivelmente, para os memorialistas em suas considerações, pesou o fato de que Desterro, mesmo após a segunda metade do século XIX, quando atingiu um relativo crescimento econômico, não possuía uma casa de espetáculos à altura de sua posição, de capital da província.

No jornal A República, encontramos um depoimento de Virgílio Várzea, que por muito tempo foi amigo de Cruz e Sousa. Várzea relembrou a ocasião em que o conheceu, aos 13 anos; o amigo contava 15. Conheceram-se durante uma solenidade artística:

[...] celebrava-se o aniversário de um dos dois teatrinhos de rapazes que lá existiam, cujos nomes não me acorrem agora. Um tinha a sua sede à antiga rua do Príncipe [atual Conselheiro Mafra] aos rés do chão do sobrado do antigo capitão de navios e capitalista Manoel Moreira da Silva, principal chefe do partido Conservador da Província; o outro à rua da Paz [atual Jerônimo Coelho] no porão da residência do Sr. Fialho, conferente da Alfândega. Desta era orador Cruz e Sousa e daquela o subscritor desta crônica, a quem coube saudar, em nome da sua sociedade dramática, a diretoria da outra. Respondeu-me Cruz e Sousa. Desde então, ficamos amigos. ${ }^{7}$

5 O Despertador, de 18 de março de 1879, apud SOARES, 1989, p. 45.

6 MONTENEGRO, 1998, p. 26.

7 VÁRZEA, 1923 apud SOARES, 1989, p. 23 
A declaração veio a confirmar a presença das tais sociedades, a participação de jovens e os poucos recursos com os quais contavam. Algumas eram formadas por jovens, estudantes, entusiastas e também abolicionistas. As peças encenadas seguiam o mesmo estilo dos dramalhões, e no caso específico destas duas sociedades à causa abolicionista começava a ser estimulada, através da leitura de poemas cheios de ideais libertários entre um ato e outro, ou ainda com a montagem de algumas peças como A escrava Andréia, ou ainda, A filha da escrava, de Artur Rocha. Mesmo atuando na maior parte do tempo em sociedades pequenas, alguns desses jovens conseguiram marcar presença por mais de uma vez no palco do Santa Izabel. Para Cruz e Sousa e Virgílio Várzea, uma destas oportunidades se deu com a passagem da Companhia Teatral de Francisco Moreira de Vasconcelos. Sua chegada foi muito festejada, sendo notícia nos jornais locais. ${ }^{8} \mathrm{O}$ elenco trazia a atriz mirim Julieta dos Santos". ${ }^{9}$ Cruz e Sousa e Virgílio Várzea aproveitaram a oportunidade para mostrar suas produções literárias entre o intervalo de um ato a outro, assim como poemas em homenagem aos atores, aniversariantes ou a figuras ilustres da cidade presentes na plateia. Atento aos interesses dos jovens, Moreira de Vasconcelos, empresário da companhia de Julieta dos Santos, se aproximou dos novos poetas para estimular essa publicidade. Desse encontro, dois resultados concretos: um emprego para Cruz e Sousa e a publicação de uma coletânea de 40 páginas em homenagem à pequena atriz, contendo 20 poemas de Cruz e Sousa, Virgílio Várzea, Santos Lostada e Moreira de Vasconcelos. Com o fim da temporada em Desterro, Cruz e Sousa partiu com a companhia, exercendo as atividades de ponto (responsável por "soprar" as falas aos atores) e secretário.

Durante a viagem, conheceu Porto Alegre, Pelotas, Rio de Janeiro, Salvador, Recife, Santos, São Paulo e São Luis do Maranhão. Mesmo na condição de livre, a realidade da escravidão nunca esteve distante de Cruz e Sousa, pois pertencia a uma família com uma longa trajetória marcada pela escravidão; seus pais foram escravos, bem como seus avós. Possivelmente dessa experiência tenha nascido, ainda em sua juventude, um espírito de luta e indignação. Nos intervalos das peças encenadas pela companhia, subia ao palco para declamar seus versos, muitos deles cheios

\footnotetext{
8 O Despertador, 23/12/1882 apud SOARES, 1989, p. 16.

9 Ibidem.
} 
de ideais libertários e abolicionistas, assim como algumas das peças representadas pela companhia.

Nos anos que antecederam o fim da escravidão, a abolição do trabalho escravo passou a ser tema recorrente na literatura. Políticos, profissionais liberais e literatos passaram a publicar nos jornais, contribuindo para o surgimento de uma nova identidade para a geração que se considerava mais atualizada e sintonizada com as tendências europeias. Envolvidos neste processo de transformação social, muitos literatos acreditaram, ou melhor, apostaram na promessa de um novo mundo, liberal, democrático, progressista e com possibilidades ilimitadas. Podiam reinventar o país e a si próprios, pregavam reformas redentoras para o país, que eram a abolição, a república e a democracia.

De volta a Desterro, Cruz e Sousa reencontrou os amigos Virgílio Várzea e Santos Lostada, e do teatro, passou aos jornais. Cruz e seus amigos fundaram um pequeno semanário literário chamado Colombo, e ao que parece, o empreendimento contava apenas com recursos próprios dos fundadores, com vida curta de alguns meses. Após o fim do Colombo, passaram a publicar em jornais locais, como Tribuna Popular e, por vezes, no A Regeneração. Contudo, a chegada, em 1883, de um novo presidente provincial, Luiz da Gama Rosa, jovem médico que trazia algumas das novidades filosóficas e literárias da capital do Império, chamou a atenção dos jovens literatos, que em torno dele se aglutinaram, a espera de novidades. Do convívio com Gama Rosa, surgiu a oportunidade de ocupar algum cargo público. Porém, tais indicações despertaram críticas e desavenças entre políticos locais. ${ }^{10}$ As críticas ao grupo revelavam a proximidade entre os jovens literatos e o presidente Gama Rosa, e a necessidade de se abrigarem sob a proteção de um valioso padrinho. Virgílio Várzea foi indicado para secretário de gabinete, Santos Lostada foi indicado para promotor público no interior da província, cargo no qual se manteve por algum tempo. Quanto a Cruz e Sousa, também recebeu uma indicação para promotor público em Laguna, sul do estado de Santa Catarina, mas foi impedido de assumir, pois uma comissão representando os interesses daquela cidade se dirigiu ao presidente Gama Rosa contestando a escolha.

10 Sobre as disputas políticas e indicações envolvendo os integrantes do grupo Idéia Nova, ver: CHEREM, 1998. 
Do convívio e da troca de experiências originou-se um grupo de jovens com uma formação identitária mais coesa, que passou a chamarse Idéia Nova. Formado por Cruz e Sousa e os amigos Virgílio Várzea, Santos Lostada e Araújo Figueiredo, logo aderiram às novidades literárias trazidas da Europa por Gama Rosa. Liam e discutiam autores como Zola, Spencer, Darwin, Haeckel, Comte, Taine, Cesário Verde, Eça de Queirós, Guerra Junqueira e, possivelmente, poetas simbolistas como Baudelaire e Mallarmé. Em meio às novidades, mostraram algumas vezes dificuldades e limitações, chegando a trocar e confundir autores e escolas literárias. Em 1885, publicaram um pequeno livro de poesias intitulado Tropos $e$ Fantasias, escrito por Cruz e Sousa e Virgílio Várzea. A obra trazia poemas repletos de ideais libertários, saudando a modernidade e o racionalismo. Com forte crítica ao romantismo e à geração de intelectuais românticos, em Desterro liderados por Eduardo Nunes Pires, referiam-se a estes como a velha guarda, algo ultrapassado que pertencia ao passado. $O$ soneto manifesto intitulado Alerta, publicado no jornal A Regeneração em 10 de janeiro de 1884, exemplifica as preocupações do grupo:

Alerta, meu amigo! - e vamos batalhar.

A luz da Idéia Nova! A linha da vanguarda!

O forte alexandrino façamos rebrilhar,

Valentes derrubemos a douda e Velha Guarda! ${ }^{11}$

A pequena obra trouxe outras composições polêmicas; seu engajamento na causa abolicionista também se fez presente através de poemas como O Padre:

Um padre escravocrata!... Horror!

Um padre, o apostolo da igreja,

Que deveria ser o arrimo dos

Que sofrem, o sacrário da bondade,

O amparo da innocencia, o Atleta civilizador da Cruz, a cornucópia

Do amor, das bênçãos immaculada, o reflexo do Christo...[...]

Fazer da igreja uma senzala, dos dogmas sacros leis de impiedade, da estola um vergalho, do missal um prostíbulo. [... $]^{12}$

\footnotetext{
11 Apud CHEREM, 1998, p. 159.

12 VÁRZEA; CRUZ E SOUSA, 1988, p. 56.
} 
Podemos perceber não apenas a condenação ao trabalho escravo, mas um sentimento anticlerical presente em Cruz e Sousa. Tal sentimento apontava uma contradição flagrante entre os princípios da fé cristã, a qual a sociedade brasileira professava desde os tempos de sua colonização luso-católica, e a realidade da escravidão. Contudo, a questão parece ser mais complexa. Para a historiadora Hebe Mattos, em seu estudo sobre escravidão e cidadania no Brasil monárquico, o fato de que:

as diversas sociedades do chamado Antigo Regime, bem como o cristianismo católico ou protestante, de uma maneira geral, com exceção de alguns grupos protestantes específicos - como os quackers - não tinham maiores problemas teóricos ou morais com a escravidão africana, que permitiria aos bárbaros, oriundos deste continente, conhecerem a verdadeira religião. No entanto, acreditavam na igualdade de todos perante o Criador. ${ }^{13}$

Cabe notarmos que a sociedade de Desterro, profundamente marcada pela estratificação social e pelas relações de dependência, era formada por cativos, libertos e livres; possuía em seus quadros administrativos portugueses e seus descendentes, que compartilhavam ainda das tradições e costumes das sociedades do Antigo Regime, ou seja, uma sociedade católica, hierarquizada, onde não se obtinha o reconhecimento sem submissão e obediência à hierarquia.

A par das novidades filosófico-literárias, aquele grupo de jovens literatos deu origem a uma inabalável fé nos postulados do progresso e da racionalidade. O historiador Nicolau Sevcenko apontou para o fato de boa parte dos intelectuais buscar uma forma de explicação para a sua realidade:

os intelectuais brasileiros voltaram-se para o fluxo cultural europeu como a verdadeira, única e definitiva tábua de salvação, capaz de selar de uma vez a sorte de um passado obscuro e vazio de possibilidades e de abrir um mundo novo, liberal, democrático, progressista e abundante de perspectivas ilimitadas como ele se prometia. $^{14}$

\footnotetext{
3 MATTOS, 2000, p. 11.
}

14 SEVCENKO, p. 78. 
Após a publicação de Tropos e Fantasias, o grupo alimentou a expectativa de encontrar seu lugar no jornalismo e na literatura. Investiram suas energias em um pequeno jornal com estilo próprio e irreverente: O Moleque. Pequeno semanário publicado quatro vezes ao mês, tinha sido fundado por Othon D’Eça, mas logo passou para os cuidados de Virgílio Várzea e Cruz e Sousa. Provocador, se autodenominava um órgão "noticioso, moderno e nervoso", criticando a morosidade e a falta de comprometimento das autoridades para com a cidade. Em nota publicada em julho de 1885, Cruz e Sousa condenou a sujeira e o estado de abandono em que se encontravam as praias:

[...] Já este assumpto de praia, não é dos mais decentes porque lembra immundice, enchurro, lodo, podridão e tal e cousa... Não obstante, todas essas rasoabilidades da Lógica, precisamos fallar da... praia e ... sempre da praia.

[...] Pois esta praia, esta tão sympathica e conhecida, que vê desfilar na sua frente todos os carnavaes, todos as procissões, carnavaes de mesma maneira, carnavaes sagrados, todas as manifestações políticas, esta praia, dizemos, não tem sequer as honras de limpeza, é uma praia suja. ${ }^{15}$

A nota oscilava entre a ironia e o ataque frontal, os problemas em torno dos esgotos e do lixo depositado nas praias, que continuaram, por um longo período, sendo o centro de muitos protestos na imprensa. A praia em questão era a do Menino Deus, local conhecido dos moradores, por onde passavam os festejos do carnaval e as procissões. No trecho seguinte da nota, com certa ironia, o autor chamava a atenção das autoridades, cobrando as devidas providências: "Se a Câmara, por um esquecimento dos seus deveres, se lembrar do limpamento da Praia do Menino Deus, nós prometheriamos uma vela de sebo a Santa Vergonha e ao Milagroso Santo Cynismo para que ella tivesse um bom parto de idéias fucturas nas fucturas presidências $[\ldots]^{\prime \prime}{ }^{16}$

Tais notas terminavam assinadas por Zé $\mathrm{K}$, que, segundo Iaponan Soares, foi um dos pseudônimos mais usados por Cruz e Sousa. ${ }^{17}$ A data

15 O Moleque, 19/07/1885, p. 2.

16 Ibidem.

17 SOARES, 1989, p.78. 
das publicações coincide com o período em que Cruz e Sousa trabalhou como colaborador em $\mathrm{O}$ Moleque. Na mesma tônica, esta pequena sátira, na qual o alvo era a atuação dos fiscais:

\section{O fiscal}

Passa na rua com ares de engenheiro,

Usa bonet, trajando blusa parda.

N'elle se encherga da polícia um guarda

Que monta um magro e trotador sendeiro

Fazer mal é capaz ao mundo inteiro;

Se vê água, uma multa nunca tarda,

De que uma parte, elle contente guarda,

A sorrir-se de alegre ante o dinheiro.

Eleitor é, mas de votar se arreda,

Si o feroz animal assim decreta,

Que em política tem a pose treda,

No districto primeiro, venenosa.

Matéria deita aos cães, esse pateta,

Que a alcunha de peito bronze goza.

$$
\text { A. d'Olpho }{ }^{18}
$$

A crítica denunciava uma relação de dependência, apadrinhamento e troca de favores entre aqueles que eram nomeados para os cargos de fiscal e a autoridade responsável por escolher e nomear tais fiscais. A nota terminava com a assinatura de A. d'Olpho, possivelmente um dos pseudônimos utilizado pelos colaboradores do jornal, ou talvez pelo próprio Cruz e Sousa.

Além de tentar imprimir uma consciência crítica acerca do ambiente sociocultural de Desterro, estes jovens passaram também a condenar as atitudes que destoavam daquilo em que acreditavam. Condenavam os castigos físicos praticados por senhores que possuíam escravos, ao mesmo tempo em que festejavam as iniciativas de alforrias, como aponta este trecho de uma nota publicada em O Moleque:

18 O Moleque, 16/04/1885, p. 3. 
Sr. João do Prado Lemos, deu liberdade a cinco escravizados.

Magnífico.

Só por isso S.S. tem todo o direito a um aperto de mão do Moleque.

E venha elle, o aperto de mão, franco sincero e robusto como o acto do digno negociante.

E anda assim que é bom.

Applausos, applausos.

Trac. $^{19}$

A causa abolicionista foi tema recorrente nas páginas de O Moleque, em poemas, bem como em críticas ao próprio partido abolicionista. Entre estas, a crítica do uso da campanha em detrimento de interesses políticos, os discursos vazios e a falta de perspectiva para os libertos após alforriados. Assim, em nota publicada na coluna Piparotes, Cruz e Sousa destacava a entrega de 28 cartas de liberdade através do fundo de emancipação:

No dia 7, a uma hora da tarde, houve no Palácio a entrega de 28 cartas de liberdade, pela caixa-fundo de emancipação provincial.

Foram distribuídas pelo Dr. Chefe de Polícia que dêo fulgôres ao acto, proferindo um bonito discurso aos libertados.

É agora a occasião de felicitar a Província e pedir-lhe em nome da liberdade que tem vivido a chorar a sombra do anachronismo escravocrata, toda a sympathia todo o amor, todo o carinho pela redempção da desgraçada raça dos tristes.

Vinte e oito cartas de Liberdade são vinte e oito bênçãos de consolo, de purificação moral [...].

Mais um passo para a igualdade dos direitos, para a comunhão das almas.

Obrigado pelos libertados do dia 7.

Trac. ${ }^{20}$

Em outra, criticava clubes abolicionistas:

19 O Moleque, $17 / 05 / 1885$, p. 1.

20 O Moleque, 05/07/1885, p. 2. 
Os Clubs abolicionistas por aqui são assim um tanto cometas:

Apparecem e ... somem como appareceram e a respeito de fazer alguma cousa de novo, relativo a abolição: quem disse ...

Patranhas, homens, patranhas, e tem-se dito tudo.

Deus o crie para o bem.

E ... tome lá uma figa para livrar de feitiços.

Pois é, não é?!!1

Suas efêmeras existências apontavam talvez a falta de coerência entre o ideal e a ação, fazendo com que diante do primeiro obstáculo, esmorecessem e deixassem de existir.

O Moleque não contava com a simpatia da alta sociedade de Desterro. Era ignorado, e seus colaboradores não recebiam convites para as festas mais importantes, como por exemplo, o jantar em comemoração ao aniversário do Clube 12 de Agosto, local onde se reuniam os abastados da cidade, e que contou com todos os representantes da imprensa local, menos os da pequena folha. Revidando o que considerou uma afronta, publicou a seguinte nota:

Uma vez que O Moleque não é um trapo sujo do monturo, um caráter enluvado com sífilis moral por dentro, um pasquim ordinário e safado, um bêbado de todas as esquinas ou um leproso de todas as lamas, havia obrigação... de ser O Moleque considerado como gente... Se não se distribuiu convite para $\mathrm{O}$ Moleque porque o seu redator-chefe é um crioulo, é preciso saber-se que esse crioulo não é um imbecil. ${ }^{22}$

Para Cruz e Sousa, o motivo que levava o jornal ser constantemente ignorado era o fato de possuir como redator, nas palavras do próprio poeta, "um crioulo". Embora possuísse mérito para ocupar o cargo, naquela sociedade oitocentista e escravocrata, a questão da cor tornouse o principal fator a impedir que Cruz e Sousa ascendesse socialmente. Mesmo contando com certo reconhecimento - pois seus poemas foram publicados na maioria dos jornais locais -, e tendo em seu círculo de

${ }_{21}$ O Moleque, 27/08/1885, p. 3.

22 Apud. MONTENEGRO, 1998, p. 48. 
relações pessoais nomes como Gama Rosa, Duarte Schutel e Germano Wendhausen, isto não foi suficiente para garantir sua entrada e permanência naquela sociedade. Suas tentativas de alargamento das possibilidades de ascensão social eram bloqueadas. Em O Abolicionismo, artigo publicado no jornal $A$ Regeneração, as referências aos ideais liberais e democráticos nos quais acreditava estão mais evidentes e apontam uma questão ainda mais importante, qual seja, o destino da população cativa após a abolição da escravidão:

A ação que o Abolicionismo tem tomado nesta capital é profundamente significativa. Nem podia ser menos franca e menos sincera a adesão de todos a esta idéia soberana, à vista dos protestos da razão humana, do patriotismo e do caráter nacional ante tão bárbara e absurda instituição - a do escravismo. [...]. ${ }^{23}$

Nesse primeiro trecho, Cruz e Sousa buscava na razão humana argumentos para combater a barbárie que a escravidão representava, bem como a condenação moral e o atraso aos quais condenava o país. Valores como patriotismo e caráter demonstram a preocupação com a formação de um sentimento de unidade, indicando a inexistência de um povo ou de uma população homogênea:

[...] Porque é preciso saber-se, em antes de se ter uma razão errada das coisas, que o Abolicionismo não discute pessoas, não discute indivíduos nem interesses; discute coletividade, discute fins gerais. Não vai unicamente pôr-se a favor do escravo pela sua posição tristemente humilde e acobardada pelos grandes e pelos maus, mas também pelas causas morais que o seu individualismo traz à sociedade brasileira, atrasando-a e conspurcando-a [...]. ${ }^{24}$

No trecho seguinte, falava em nome de um interesse coletivo, condenando os interesses individuais:

Não se pensa que com a libertação do escravo, virá e estado de desorganização, de desmembramento no corpo ainda não unitário do país. [...] Às forças governistas compete firmar a existência

\footnotetext{
23 SOARES, 1998, p. 138.

24 Ibidem, p. 139.
} 
do trabalho do homem tornado repentinamente livre, criando métodos intuitivos e práticos de ensino primário, coloniais rurais, estabelecimentos fabris, etc [...]. ${ }^{25}$

Atribuía aos governistas a responsabilidade de integrar este homem livre à sociedade. Integração que se daria através do reconhecimento e da garantia de seus direitos:

A escravidão recua, o Abolicionismo avança, mas avança seguro, convicto como uma idéia, como um princípio, como uma atitude. Até agora o maior poder do Brasil tem sido o braço escravo: dele é que parte a manutenção e a sustentação dos indivíduos de pais dinheirosos; com o suor escravo é que se fazem deputados, conselheiros, ministros, chefes de Estado. Por isso no país não há indústria, não há índole de vida prática social, não há artes [...]. ${ }^{26}$

$\mathrm{Na}$ tentativa de chamar a atenção para as injustiças cometidas por esta sociedade, que viveu durante séculos do trabalho escravo, destacou a importância do escravo na economia do país, sustentáculo de uma gigantesca estrutura de poder, colocando a responsabilidade do atraso social na inércia causada pela escravidão e ressaltando a responsabilidade dos dirigentes políticos.

Mesmo no pequeno ambiente literário de Desterro, a publicação de Tropos e Fantasias não passou despercebida pela crítica local; Francisco Antônio das Oliveiras Margarida, diretor do jornal O Abolicionista, reconheceu certa originalidade que poderia progredir, desde que acompanhasse o estilo dos mestres da época. E acrescentou. "O soneto do Sr. Cruz nada tem de admirável e de novo a não ser os inúmeros cacófatos e erros de metrificação que o recomendam ainda mais aos críticos sensatos, ilustrados e de grande mérito". ${ }^{27}$ Entretanto, em nota publicada no Jornal do Comércio, Cruz e Sousa rebateu as críticas recebidas:

Há duas coisas no Brasil que são como que homogêneas. A política e a poesia, por não serem tomadas convenientemente a sério,

\footnotetext{
25 Ibidem.

26 Ibidem, p. 140.

27 Ibidem, p. 48.
} 
por serem entregues a muitos espíritos pueris, duma penetração frívola e vulgar. Falar em poesia é, neste país, para a compreensão fácil e leviana de indivíduos inconscientes da verdade filosófica das grandes coisas tangíveis, uma imbecilidade, um entretenimento inútil, uma aspiração oca, vazia de senso e de critério. ${ }^{28}$

Após as inúmeras tentativas sem sucesso de permanecer em Desterro vivendo das letras, ou ainda, de algum cargo público, Cruz e Sousa partiu para a capital do Império em junho de 1888, como a maioria de seus amigos e integrantes do Ideia Nova e boa parte dos homens que desejavam viver das letras no país. Sua passagem pela cidade do Rio de Janeiro marcou de forma significativa sua trajetória de vida, representando um dos períodos mais ricos de sua produção literária, ao mesmo tempo em que a fase mais difícil de sua vida. Foi recebido por seus amigos Oscar Rosas e Araújo Figueiredo. Oscar Rosas encarregou-se de acolhê-lo em sua casa; estudara com o poeta no Ateneu Provincial e, com 15 anos, mudou-se com as tias, parentes do pintor catarinense Vitor Meireles, para o Rio de Janeiro; ali, trabalhou na imprensa e manteve contatos com políticos importantes. De espírito polêmico, muitas vezes descrito como extravagante e truculento, se declarou um grande apreciador da estética simbolista.

Mesmo que recebido de forma positiva por algumas pessoas da imprensa, amigos e colegas de Oscar Rosas, isso não foi suficiente a Cruz e Sousa para garantir um espaço nos jornais cariocas. Passou então a escrever como colaborador nestes, porém, o rendimento do trabalho apenas lhe garantia as necessidades mais emergenciais. Com o passar dos meses sem receber uma proposta de emprego fixo que lhe garantisse estabilidade, Cruz retornou por poucos meses a Desterro, voltando à capital do Império cheio de expectativas para um novo recomeço. Era um período de recrudescimento nas relações raciais. As teorias raciais formuladas a partir da segunda metade do século XIX nos Estados Unidos e na Europa tiveram grande impacto no Brasil no período entre as últimas décadas do século XIX e as primeiras décadas do século XX.

Estabelecido na capital, escrevendo em pequenos jornais e colaborando em revistas literárias, Cruz e Sousa aglutinou um grupo de literatos simbolistas, cariocas e paranaenses, entre eles, Emiliano

28 CRUZ E SOUSA, 1885 apud MONTENEGRO, 1998, p. 51. 
Perneta, Nestor Vitor, Lima Campos e Gonzaga Duque; juntos, escreviam e publicavam, desenvolvendo intensa atividade cultural. Alguns fundaram revistas importantes como, a Revista Rio e a Fon-Fon. Neste período, Cruz e Sousa conheceu Gavita Gonçalves, jovem negra proveniente de uma família com poucos recursos. Era alfabetizada e trabalhava como costureira de uma grande oficina. Ao final do ano de 1893, Gavita e Cruz e Sousa casaram-se. Gavita foi descrita por Maria de Lourdes Filgueira Balassiano, neta de Nestor Vitor, como uma mulher elegante e de trato refinado, com um falar fluente e bastante argúcia, senso crítico e uns olhos que chamavam muito a atenção. ${ }^{29}$

Veio, assim, a necessidade de garantir a sobrevivência da família. Com a ajuda do amigo Nestor Vitor, Cruz e Sousa conseguiu ocupar o cargo de praticante de arquivista na Central do Brasil; ganhando muito pouco, recorria com frequência aos amigos pedindo-lhes empréstimos. Também em 1893, publicou Missal e Broquéis. As duas obras foram publicadas pela Magalhães e Companhia, sendo expostas na Livraria Moderna, principal reduto dos intelectuais carioca. As expectativas em relação às obras não se realizaram e o recrudescimento das teorias raciais se fez ainda mais evidente nas críticas aos seus trabalhos, principalmente as que partiram de Araripe Júnior, Sílvio Romero e José Veríssimo.

A crítica de Araripe Júnior ao poeta estava assentada sobre duas certezas inabaláveis para o autor: a teoria determinista e o discurso racial. Araripe achava curioso o interesse de um artista de origem africana por uma estética com traços supostamente europeus. Para ele, o fato de Cruz e Sousa possuir uma ascendência africana o incapacitava de compreender a estética literária simbolista, pois faltava-lhe a sensibilidade europeia; era, para o crítico, puro poeta astral antropomórfico das raças primitivas. ${ }^{30}$

Sílvio Romero, crítico bastante conhecido dos intelectuais do período, pautava-se nos modelos cientificistas e naturalistas. Seu pensamento foi definido por Antonio Candido como um turbilhão de ideias, por conta das muitas influências que constituíram a base de sua formação (evolucionismo, determinismo, positivismo entre outras). Romero buscava a regeneração do caráter brasileiro. $\mathrm{O}$ caminho seria o "branqueamento", para se reabilitar as raças "inferiores", integrando-as

\footnotetext{
29 ALVES, 1990, p. 30

30 BARBOSA, 1977, p. 35.
} 
à civilização. Através do cruzamento e da mistura progressiva seriam logo extintas. Por diversas vezes, tentou assimilar as bases intelectuais e cientificistas europeias, transformando-as em bases próprias, que fornecessem instrumento de análise da realidade brasileira. Foi através deste esforço que buscou compreender o movimento simbolista no Brasil, de início com certa simpatia, chegando a reconhecer no Simbolismo mais que uma literatura importada ou uma imitação do modelo francês, mas uma forma legítima de expressão estética. Criticou a forma hostil como o Simbolismo foi recebido no Brasil, principalmente por Araripe Júnior, afirmando que faltava à nossa crítica instrumentos capazes de entender o movimento. Quanto a Cruz e Sousa, Romero não podia deixar de notar a condição racial do poeta, afirmando que ele era o caso único de um negro puro, verdadeiramente superior no desenvolvimento da cultura brasileira. ${ }^{31}$ Mesmo que simpático ao Simbolismo, Romero fez uma análise do movimento a partir dos parâmetros predominantes entre os demais críticos, o meio e a raça, levando em alta conta a questão racial e a teoria evolucionista. Para ele, Cruz e Sousa era superior porque soube dominar os códigos culturais da civilização e da literatura de sua época; o poeta seria a prova de que através da incorporação dos elementos da cultura branca europeia era possível livrar o país da barbárie e do atraso causado pela escravidão.

O último crítico pertencente ao grupo, José Veríssimo, que priorizou o caráter estético em sua análise. Entretanto, mostrou pouca disposição e simpatia pelo movimento simbolista, que para ele se resumia a um caso de "macaqueação", reiterando a crítica de Araripe Júnior. Quanto ao principal nome do movimento simbolista brasileiro, Veríssimo afirmava que sua musicalidade, a repetição dos versos e os sons que representavam a beleza e riqueza dos poemas nada mais eram que um verdadeiro cacoete, próprio dos primitivos. Os critérios adotados por Veríssimo ao analisar a poesia de Cruz e Sousa também se pautaram em bases racistas. Naquele final de século, tinha-se um jovem poeta negro vivendo em uma sociedade marcada pela escravidão e pelo fortalecimento do discurso que saudava a modernidade, o pensamento liberal e a inclusão do Brasil na nova ordem de prosperidade e riqueza. Período pleno de contradições e ambiguidades, pois o mesmo pensamento liberal que pregava um mundo cheio de

31 Apud AlBUQUERQUE, 2004, p. 88. 
possibilidades para os indivíduos dividia espaço com a discriminação racial, que produzia a exclusão social de uma parte significativa da população.

Cruz e Sousa viveu, como muitos homens livres descendentes dos africanos, as dificuldades de inserção social naquela sociedade de final de século. No Rio de Janeiro, entrou em contato com uma literatura produzida por poetas em sua maioria franceses, identificados com a sensibilidade decadentista, de crítica à modernidade, como Baudelaire, Edgar Allan Poe, Huysmans, Villiers de L'Isle-Adam e Joséphin Péladan. Passou a identificar-se com aquela sensibilidade de decadência, refinando sua escrita. A experiência de viver em uma cidade num processo de modernização excludente, a nova experiência política da República, fase turbulenta com disputas canhestras, arranjos e vícios de compadrio produziram em Cruz e Sousa um sentimento de decadência e decepção. ${ }^{32}$ Seus poemas publicados postumamente trazem sentimentos de revolta, decepção, exclusão, preconceito, falta de perspectivas e, principalmente, decadência do espírito, com valores materiais se sobrepondo aos do espírito.

Com a saúde bastante fragilizada por conta da tuberculose, Cruz e Souza faleceu em uma estação de repouso no interior de Minas Gerais, em 19 de março de 1898. Após sua morte, foram publicados Evocações, Faróis e Últimos Sonetos. Sua poesia representou uma renovação na expressão poética, pois a originalidade e a força presentes em seus versos remetiam a novos significados. O desencanto com os ideais libertários, as bandeiras que defendeu em sua juventude e os sonhos nos quais acreditou um dia realizar produziram em Cruz e Sousa uma sensibilidade de decadência, transformada em poesia de protesto. Talvez o poema que melhor represente sua condição seja Emparedado:

Artista! Pode lá isso ser se tu és d’África, tórrida e bárbara, devorada insaciavelmente pelo deserto, tumultuada de matas bravias, arrastada sangrando no lodo das Civilizações despóticas, torvamente amamentada com o leite amargo e venenoso da Angústia! A África arrebatada nos ciclones torvelinhantes das Impiedades supremas, das Blasfêmias absolutas, gemendo,

32 ALBUQUERQUE, 2004. 
rugindo, bramando no caos feroz, hórrido, das profundas selvas brutas, a sua formidável dilaceração humana! A África laocoôntica, alma de trevas e de chamas, fecundada no Sol e na Noite, errantemente tempestuosa como a alma espiritualizada e tantálica da Rússia, gerada no Degredo e na Neve - pólo branco e pólo negro de Deus! [...]. ${ }^{33}$

Como literato, nunca chegou a fazer parte da Academia Brasileira de Letras. Ao contrário, de alguns de seus membros é que partiram as críticas mais duras sobre sua estética e sua postura intelectual. Atualmente, Cruz Souza é o patrono da cadeira número 15 da Academia Catarinense de Letras, ocupada por Celestino Sachet.

\section{Fontes}

\section{CORRESPONDÊNCIAS}

Carta a Germano Wendhausen. Desterro, 2 de abril de 1888.

Carta a Corte, junho de 1888.

Carta a Virgílio Várzea. Corte, 8 de janeiro de 1889.

Carta a Araújo Figueiredo. Ondina, 2 de abril de 1890.

Rio, 8 de janeiro de 1897.

Carta a Gonzaga Duque. Rio, 11 de abril de 1894.

Carta a Nestor Vitor. Rio, 16 de dezembro de 1894.

Rio, 18 de março de 1896.

Carta a Carolina Eva da Conceição. s/d.

Carta a Guilherme de Sousa.

Carta a Gavita. Rio, 31 de março de 1892.

PERIÓDICOS

O Moleque, 1885.

A Regeneração, 1883, 1885 e 1886.

O Conservador, 1875.

33 CRUZ E SOUSA, 1995, p. 672. 
ALBUQUERQUE, Henrique Cavalcanti. Decadentismo de desilusão: o desencanto pela modernidade na Literatura do Rio de Janeiro da Belle Époque. Dissertação (Mestrado em História) - Pontifícia Universidade Católica, São Paulo, 2004.

ALVES, Uelinton Farias. Reencontro com Cruz e Sousa. Florianópolis: Papa-livros, 1990

BOSI, Alfredo. História concisa da Literatura Brasileira. São Paulo: Cultrix, 1994.

CABRAL, Oswaldo Rodrigues. Nossa Senhora de Desterro: memória I e II. Florianópolis: Lunardelli, 1977.

1979.

. Nossa Senhora de Desterro. Notícias I e II. Florianópolis: Lunardelli,

CARDOSO, Paulino de Jesus. Negros em Desterro 1860-1888. Tese (Doutorado em História) - Pontifícia Universidade Católica, São Paulo, 2003.

CARVALHO, José Murilo de. Os Bestializados. O Rio de Janeiro e a República que não foi. São Paulo: Companhia das Letras, 1999.

CHEREM, Rosangela Miranda. Os faróis do tempo novo. Política e cultura no amanhecer republicano da capital catarinense. Tese (Doutorado em História) Pontifícia Universidade Católica, São Paulo, 1998.

COLLAÇO, Vera Regina. Um painel do teatro catarinense no século XIX: com enfoque em Nossa Senhora do Desterro. Dissertação (Mestrado em História) Pontifícia Universidade Católica, São Paulo, 1984.

CRUZ E SOUSA. Obra Completa. Poesia. Organização geral por Andrade Muricy. Rio de Janeiro: Editora José Aguilar, 1961.

. Obra Completa. Prosa. Organização geral por Andrade Muricy. Rio de Janeiro: Editora José Aguilar, 1961.

. Obras Completas. Rio de Janeiro: Nova Aguiar, 1995.

. Dispersos: poesia e prosa. SOARES, Iaponan (Org.). São Paulo: UNESP, Giordano, 1998.

1998.

. Missal e Broquéis. TEIXEIRA, Ivan (Org.). São Paulo: Martins Fontes,

JÚNIOR, Raymundo Magalhães. Poesia e vida de Cruz e Sousa. 3 ed. Rio de Janeiro: Civilização Brasileira, 1975.

MATTOS, Hebe Maria. Escravidão e cidadania no Brasil Monárquico. Rio de Janeiro: Jorge Zahar. 2000. 
MONTENEGRO, Abelardo F. Cruz e Sousa e o Movimento Simbolista no Brasil. 3. ed. Florianópolis: FCC edições; Fortaleza: EUFC, 1998.

MURICY, Andrade. Introdução, cronologia e notas. In: Obras Completas de Cruz e Sousa. Rio de Janeiro: José Aguilar Editora, 1961.

. Panorama do Movimento Simbolista Brasileiro. 3. ed. São Paulo:

Perspectiva, 1987, 2 v.

MUZART, Zahide Lupinacci (Org.). Cartas de Cruz e Sousa. Florianópolis: Letras Contemporâneas, 1993.

SCHWARCZ, Lília Moritz. O espetáculo das raças. Cientistas, instituições e questão racial no Brasil 1870-1930. São Paulo: Companhia das Letras, 1993.

SEVCENKO, Nicolau. A literatura como missão: tensões sociais e criação cultural na Primeira República. São Paulo: Brasiliense, 1989.

SLENES, Robert. Na senzala, uma flor. Rio de Janeiro: Nova Fronteira, 1998.

SOARES, Iaponan. Ao redor de Cruz e Sousa. Florianópolis: UFSC, 1988.

VERÍSSIMO, José. In: BARBOSA, João Alexandre (Org.). José Veríssimo: teoria, crítica e história literária. São Paulo: Edusp, 1977. 


\section{|| Capítulo 11 ||}

\section{Patápio Silva: trajetória do flautista interrompida em Florianópolis}

Maurício Oliveira

O enterro do flautista Patápio Silva parou Florianópolis na tarde de quinta-feira, 24 de abril de 1907. Gente de todas as classes acompanhou o cortejo a partir do saguão do Hotel do Comércio, no qual o músico se hospedara seis dias antes e morrera durante a madrugada, vitimado por uma doença misteriosa. "À passagem do féretro viam-se todas as habitações repletas de famílias, que derramavam copiosas lágrimas lamentando a perda de tão glorioso brasileiro", registrou o jornal Reforma. ${ }^{1}$ Aos 26 anos, já famoso em todo o Brasil, Patápio fazia uma turnê pelo sul do país com o objetivo de juntar dinheiro para continuar os estudos na Europa. Chegara à capital catarinense aparentando saúde plena, mas no dia marcado para a apresentação, foi acometido por uma febre que o deixou progressivamente delirante. Nem mesmo o melhor médico da cidade, Antônio Bulcão Viana, conseguiu reverter o quadro. Em dúvida sobre a causa da morte, ele anotou na certidão de óbito um diagnóstico genérico: gripe adinâmica.

Enquanto o corpo baixava à sepultura, na cova rasa 22.964, o estudante de Direito Fúlvio Aducci, 23 anos, que viria a se tornar governador de Santa Catarina, pediu a palavra: "Esmaga-me o coração ver, compreender, sentir que dentro deste horrível caixão desaparece para sempre, na pavorosa escuridão deste poço, o extraordinário talento de um artista cuja divina inspiração musical já nos acostumamos a considerar

1 Reforma, 25/04/1907. 
uma glória patrícia", discursou, conforme registro do jornal O Dia. ${ }^{2}$ Jornais do Rio de Janeiro e de São Paulo elogiaram as homenagens prestadas em Florianópolis ao grande nome da música nacional, que morrera por acaso na cidade.

Mulato, de origem humilde, nascido em Itaocara (RJ) e criado em Cataguases (MG), Patápio se destacou como aluno do curso de flauta do Instituto Nacional de Música do Rio de Janeiro, capital federal à época. Antes de ser reconhecido pelo seu talento de músico e compositor, contudo, tornara-se célebre como vítima do "caso da flauta encantada", apelido que a imprensa da época deu ao episódio do sumiço da flauta de prata com a qual Patápio seria presenteado ao final do curso, por ter sido um aluno de destaque. Doada por uma dama da alta sociedade carioca, a flauta sumiu dos armários da escola no dia da solenidade da entrega. A situação se tornou bastante constrangedora para os administradores do Instituto, especialmente em decorrência da ampla cobertura dada por veículos satíricos como $O$ Malho. Só três meses depois o caso chegou ao fim, com o reaparecimento do instrumento no mesmo armário de onde sumira.

Naquela virada de século, seguir a carreira de músico era uma das poucas possibilidades de futuro digno para os jovens oriundos de famílias pobres. Nesse sentido, a música representava mais ou menos o que o futebol representa hoje. Se tivesse nascido um século mais tarde, Patápio provavelmente trocaria a flauta que o acompanhava nas brincadeiras infantis por uma bola e sonharia com um futuro de fama e fortuna como jogador. Havia um grande número de mulatos e negros dedicados à música popular no Rio de Janeiro da época. O diferencial de Patápio foi ter transitado com sucesso - e não apenas como instrumentista, mas também como compositor - pela seara da música erudita, típico produto da sofisticação europeia. Nesse caminho, deparou-se com diversas situações de preconceito, velado ou explícito. Um caso relatado pela Gazeta de Notícias como homenagem póstuma dá boa noção da resistência enfrentada pelo flautista:

Quando entrava num salão, a impressão não era boa. Ele próprio o sentia, ele próprio o dizia. Olhavam-no como quem esperava um

2 O Dia, 25/04/1907. 
insucesso. Mas Patápio perfilava-se, aos lábios levava a flauta, saía um som, saía outro, um gorjeio, um trinuio e, minutos depois, a sala era toda dele, havia destruído todas as desconfianças. Contam (a roda dos novos sabe isto) que uma vez ele fora levado a um dos salões "chics" de Botafogo. Ao entrar na sala houve sorrisos abafados. Quem seria aquele mestiço que tinha assim direito de entrar no esplendor de um salão?! O próprio dono da casa não o conhecia, o próprio dono da casa olhou-o com maus olhos. O rapaz que o havia levado à festa percebera o ambiente, o pobre do Patápio percebera também e não fizera caso. Estava já acostumado. Chegou a hora de se fazer música. Patápio tocou. Meia hora depois era a menina dos olhos daquela gente toda. ${ }^{3}$

\section{Af cpaf cxj_ dek kc}

Foi ainda no tempo em que estudava no Instituto Nacional de Música que Patápio se tornou o primeiro instrumentista a gravar um disco solo no Brasil, sob encomenda da Casa Edison. Depois da celebridade trazida pelo caso da "flauta encantada", o pioneirismo no mercado fonográfico o tornou conhecido de vez, de Norte a Sul do país, a ponto de ser citado por Erico Verissimo em seu livro de memórias, Solo de Clarineta:

De quando em vez meu pai aproximava-se do gramofone, davalhe corda, punha-lhe no prato um disco, cuja melodia, fanhosa e metálica, pouco depois enchia o ambiente. O famoso flautista brasileiro Patápio Silva interpretava, numa chapa da Casa Edison, do Rio de Janeiro, a Serenata de Schubert, música que provocava em mim uma dessas inexplicáveis tristezas de apertar o peito. ${ }^{4}$

A inesperada morte de um rapaz em pleno vigor da juventude causava estranheza - e os boatos tomaram conta de Florianópolis já durante o enterro. Dizia-se que ele havia sido envenenado, no bocal da própria flauta, por um figurão da política local interessado na bela mulher que o acompanhava na turnê pelo Sul. Foi um boato tão forte, que persistia quatro décadas depois da morte do flautista, em 1946, quando

3 Gazeta de Notícias, 25/04/1907.

4 VERISSIMO, 1973, p. 73. 
242 o compositor e pesquisador musical Almirante apresentou um programa especial sobre Patápio em seu horário na Rádio Nacional, do Rio de Janeiro, de grande audiência em todo o país. ${ }^{5}$ Almirante havia pedido aos ouvintes que enviassem informações sobre o flautista. Algumas das cartas recebidas comentavam as circunstâncias de sua morte e relembravam os boatos de envenenamento.

Os autores da monografia Patápio - Músico Erudito ou Popular? ouviram o testemunho de Sebastião Vieira, que tinha 12 anos quando o flautista morreu. De acordo com Vieira, que trabalhava como tipógrafo no jornal O Dia, a cidade ficou em rebuliço não só com a presença de Patápio, mas também com "a beleza da linda paraguaia" que o acompanhava, hospedada no mesmo hotel. A versão da "paraguaia" foi citada em outra ocasião por mais uma testemunha ocular, José Bonifácio Camejo, que escreveu ao jornal $O$ Estado para comentar a série de três artigos publicados em 1977, por Abelardo Sousa, sobre Patápio - motivados pelo fato de que a novela Nina, então no ar pela TV Globo, trazia como tema de abertura a valsa Primeiro Amor, de Patápio:

Sr Redator: Com muito interesse, li o artigo do sr Abelardo Sousa, na edição deste matutino de domingo, 17/7, sobre o grande Patápio Silva, aqui falecido em 1907. Assisti, garoto ainda, os funerais do inditoso músico, acompanhando o féretro até o antigo cemitério público. [...] O sr. A. Sousa por educação, por princípios éticos, aliás muito apreciáveis, não fez menção à companheira do desditoso Patápio. Belíssima mulher de origem paraguaia, parece. Também não venho especialmente meter minha colher, mas, como dizem os franceses: "cherchez la femme". ${ }^{6}$

No terceiro artigo sobre Patápio, Abelardo Sousa contou ter recebido uma carta, assinada por F. Gouvêa ("pessoa que não conheço", ressaltou), com comentários adicionais sobre o que José Bonifácio Camejo havia escrito. Dizia a carta:

O sr. Camejo, em sua carta, usando da expressão "cherchez la femme”, parece haver timidamente tentado aflorar o assunto

\footnotetext{
5 Citado em SOUZA, 1983; o programa teria ido ao ar em 19 de março de 1946.

6 O Estado, 3/08/1977.
} 
(morte de Patápio), que não ousou, entretanto, aprofundar, talvez, entre outros motivos, por não lhe deixarem os seus treze ou quatorze anos de idade, que tinha à época, discerni-lo com segurança. Falava-se na ocasião que alto funcionário do Estado, chefe de família com prole numerosa, havia presenteado a bela companheira do grande flautista com uma jóia valiosíssima (creio que anel) e que essa peça rara havia sido subtraída, pelo próprio funcionário, de alguém que era nada mais, nada menos, que sua legítima esposa, senhora de peregrinas virtudes. [...] O escabroso episódio, "potin" do ano, assunto de todas as rodas da nossa então pacata cidade, teve, alguns meses mais tarde, as honras da letra de forma na "Gazeta Catarinense", diário que fazia cerrada oposição ao governo local. Se o prezado professor se der ao trabalho de compulsar as coleções daquele órgão de imprensa, anos de 1907, 1908 ou 1909, existentes na nossa Biblioteca Pública, certamente ali encontrará, com abundância de pormenores, a descrição do fato a que me refiro e a citação, com todas as letras, dos nomes nele envolvidos. O jornal em questão foi, em conseqüência, ocupado e empastelado pelo Governo do Estado, o que revela a exaltação do momento, mas havendo o seu diretor obtido habeas corpus do Supremo Tribunal Federal, era de ver-se, dias depois, os pequenos jornaleiros, cada um acompanhado de uma praça embalada do exército, apregoando a venda avulsa pelas ruas e praças da Capital! ${ }^{7}$

O jornal O Dia, dirigido por Tiago da Fonseca, era alinhado ao Partido Republicano, que estava no poder. No ano seguinte ao da morte de Patápio, a oposição passou a se manifestar por meio do jornal A Gazeta Catarinense, dirigida por Hercílio Luz. O que Gouvêa contava na carta era que, quando A Gazeta soube da história do líder rival que roubara uma joia da própria esposa para presenteá-la a outra mulher, a teria publicado, causando, naturalmente, enorme embaraço.

Infelizmente não foi possível confirmar essa versão ao pesquisar os arquivos de $A$ Gazeta Catarinense. Nos números que constam das incompletas coleções encontradas na Biblioteca Pública de Santa Catarina, em Florianópolis, e na Biblioteca Nacional, no Rio de Janeiro, não há referência ao episódio. Teriam sido os números comprometedores extraídos por alguém interessado em esconder o passado - ou pelo menos

7 O Estado, 21/08/1977. 
seus detalhes mais picantes? E quem seria a bela mulher que acompanhava Patápio? A pesquisa nos jornais de Florianópolis dos dias seguintes ao da morte do flautista revelou o nome da atriz e cantora Laly Mafaldi - italiana, que pode ter sido perfeitamente confundida com uma paraguaia. Em visita ao jornal $O$ Dia no dia seguinte à morte do músico, Laly contou que

era sua intenção, manifestada a diversas pessoas, mandar erigir um mausoléu à memória do seu distinto colega de arte. Entretanto, para não tirar à mocidade catarinense a glória de prestar essa homenagem ao moço extraordinário que conquistara tão avantajada posição no mundo da arte, declara associar-se à idéia dos jovens catarinenses, concorrendo com a quantia que estes julgarem necessária para tão nobre fim. Além disso, fará ela uma oferta para o Asilo de Órfãos, a fim de que as meninas asiladas roguem a Deus pela alma de Patápio. ${ }^{8}$

É fácil imaginar a estranheza despertada pelo relacionamento entre um mestiço e uma beldade branca numa pequena cidade como Florianópolis, que contava à época com não mais que 15 mil habitantes - e o burburinho que isso deve ter causado em um lugar tão provinciano e conservador. Passadas apenas duas décadas da abolição da escravatura, o público que aguardava pela apresentação de Patápio no Clube 12 de Agosto, composto pela elite branca da capital catarinense, possivelmente não estava ainda preparado para uma demonstração tão explícita de que os tempos eram, de fato, outros.

Mesmo em centros maiores, como o Rio de Janeiro, o "esperado" era que homens mestiços ou negros se relacionassem apenas com mulheres mestiças ou negras. Se alguém podia subverter a ordem estabelecida, eram os rapazes brancos de origem simples, que tinham dificuldade para se aproximar de moças brancas oriundas de famílias em condições semelhantes ou superiores, uma vez que essas moças almejavam se relacionar com rapazes de alto nível social. ${ }^{9}$

8 O Dia, 27/04/1907.

9 ABREU, 1989. 
Patápio morreu às duas horas da madrugada, e às seis, o comissário de polícia da capital, Fernando Machado, compareceu ao Hotel do Comércio. Na ausência de parente do finado, Machado recolheu seus bens, tendo como testemunhas o tenente-coronel Manoel Vicente Ferreira de Melo, comandante do 3o Batalhão, e José Leite de Macedo, o proprietário do Hotel do Comércio. Os bens foram entregues ao juiz de direito da comarca, que, em seguida, nomeou o dono do hotel depositário dos bens deixados por Patápio.

A notícia correu assim que o dia amanheceu, comovendo a cidade. O jornal O Dia distribuiu um boletim extraordinário, convocando os moradores para o enterro: "Tendo falecido hoje às 2 horas da madrugada o festejado flautista brasileiro Patápio Silva, convidamos a todos para conduzi-lo ao Cemitério Público, devendo o enterro sair do Hotel do Comércio às $4 \frac{1 / 2}{2}$ da tarde". ${ }^{10}$ Os jornais do Rio de Janeiro e de São Paulo foram informados ao final da manhã por um telegrama enviado pelo secretário do governo de Santa Catarina, Honório da Cunha. Além de descrever o ocorrido, Cunha afirmava que todas as despesas decorrentes da enfermidade e do funeral de Patápio ficariam por conta do governo de Santa Catarina - o que na realidade não ocorreu, como veremos adiante.

Uma das coroas colocadas ao redor do caixão durante o velório trazia a inscrição "lembrança de uma atriz", provável homenagem de Laly Mafaldi. Após a encomenda do corpo feita pelo padre Francisco Xavier Giessbert, o cortejo seguiu rumo ao cemitério, a dois quilômetros dali - no local que viria a ser a cabeceira da ponte Hercílio Luz, a primeira ligação entre a ilha e o continente, inaugurada em 1926. Em determinado momento, o caixão era carregado por seis maestros locais - Adolfo Melo, Pedro Alves Pavão, Max Freyesleben, Raimundo Bridon, Alexandre Wolff e Constantino Böeckler. A Banda do Corpo de Segurança e a Sociedade Musical Amor à Arte, fundada em 1897 e existente até hoje, executaram marchas fúnebres ao longo do trajeto.

Era um desfecho triste para dias que foram tomados por dois tipos de expectativa: inicialmente pela chegada do famoso músico e depois,

10 O Dia, 24/04/1907 (boletim extra). 
pela sua recuperação. A presença de um artista de fama nacional era algo raro para a capital catarinense, que aguardava com ansiedade o concerto do flautista, como ficava claro nas palavras do cronista de O Dia:

\begin{abstract}
A nossa sociedade, tão pobre de distrações artísticas, vai ter dentro de poucos dias o prazer de ouvir um flautista de raro merecimento. Referimo-nos a Patápio Silva, chegado anteontem do Norte. Apesar de moço ainda, Patápio Silva não é, no nosso acanhado meio musical, um nome desconhecido; os ecos de seus brilhantes sucessos na Capital Federal e em São Paulo já tinham percutido entre nós, trazendo-nos vitoriosamente a forma de sua grande e invejável aptidão musical. [...] Dizem os críticos que a sua flauta, mágica ao sopro duma inspiração superior, obediente, escrava duma alma sonhadora e afetiva, sabe interpretar, com poderosa maestria, os mais difíceis e delicados pensamentos musicais. ${ }^{11}$
\end{abstract}

Patápio chegou à cidade em uma sexta-feira, 12 de abril de 1907. Hospedou-se no Hotel do Comércio, localizado à Rua Altino Correia, atual Conselheiro Mafra. O prédio ficava então à beira-mar - na década de 1970, o aterro da Baía Sul afastaria o mar para quase um quilômetro dali. Nos dias que restavam até o espetáculo, marcado para a quinta-feira seguinte, dia 18, no Clube 12 de Agosto, Patápio realizou ensaios no hotel, em companhia do maestro e também flautista Álvaro Sousa, compositor de obras para orquestra, piano, violino e flauta, e de outros músicos locais. Alguns foram convidados por Patápio para acompanhá-lo no concerto: era o caso das pianistas Maria Sales, Luiza Couto, Leonie Lapagesse e da cantora Maria Couto, além do maestro Adolfo Melo. O programa anunciado no jornal O Dia, na véspera do concerto, era o seguinte:

Primeira parte:

I. DONIZETTI. Lucia di Lammermoor. Piano a quatro mãos, senhorita Leonie e d. Maria Sales.

II. POPP. Fantasia. Flauta. Patápio.

III. A. MELO. Solo de estudo. Violino. Pelo autor.

IV. LÉONARD. Fantaisie sué doise. Flauta. Patápio.

V. ALMAGRO. Non ti destare. Canto. Senhorita Maria Couto.

11 O Dia, 14/04/1907. 
VI. PATÁPIO. Variação sobre o Carnaval de Veneza. Flauta. Pelo autor.

Segunda parte:

VII. NESSLER. O Grito. Piano. Senhorita Leonie Lapagesse.

VIII. RUBINSTEIN. Melodie. Flauta. Patápio.

IX. PUCCINI. Visse d'arte (Tosca). Canto. Senhorita Maria Couto.

X. A. MELO. Berceuse. Violino. Pelo autor.

XI. C. GOMES. Il Guarany (Fantasia). Flauta. Patápio. ${ }^{12}$

Quando chegou o esperado dia 18, quem estava se preparando para a noite de gala foi surpreendido pela notícia de que o espetáculo seria adiado, em decorrência de um repentino mal-estar sofrido por Patápio. A capa do jornal Reforma chegou a anunciar a apresentação do flautista, mas a página dois trazia um esclarecimento: "Já estava impressa a primeira página, em que noticiamos o concerto em que devia ter lugar hoje, quando soubemos ter sido acometido de influenza o exímio professor sr Patápio Silva, por cujo motivo ficou adiado para sábado". ${ }^{13}$

Todo o litoral catarinense estava sendo fortemente atingido pela gripe naquele momento. A análise da estatística demógrafo-sanitária de Florianópolis em 1907 deixa claro que a capital enfrentava um surto de gripe em abril, quando Patápio chegou à cidade. Foram 12 casos fatais naquele mês, metade dos 25 óbitos causados pela doença ao longo de todo o ano. ${ }^{14} \mathrm{Na}$ sessão de abertura do Congresso Representativo, em 5 de agosto de 1907, a mensagem lida pelo governador, coronel Gustavo Richard, fez menção ao surto, embora reduzindo as proporções do problema: "O estado sanitário nestes doze últimos meses foi satisfatório e só na passagem do verão para o inverno foi que apareceram alguns casos de gripe" ${ }^{15}$ No ano anterior, haviam sido apenas sete os casos de morte provocada pela gripe na cidade, concentrados entre abril e julho. Mas naquele mês de abril de 1907, os 12 óbitos decorrentes da gripe a transformaram na principal causa das 60 mortes registradas em Florianópolis. As más condições de

12 O Dia, 17/04/1907.

13 Reforma, 18/04/1907.

14 Os outros 13 óbitos foram registrados em sete diferentes meses, nenhum deles com mais de três casos.

15 Mensagem lida pelo Exmo. Cel. Gustavo Richard, Governador do Estado, na sessão de abertura do Congresso Representativo, Florianópolis: Gab. Typ. d'O Dia, 1907, p. 13. 
saúde pública se agravavam ainda mais com as intempéries. Já com Patápio na cidade, Florianópolis registrou uma forte lestada, acompanhada de chuvas torrenciais. Em seu clássico Santa Catarina, A Ilha, Virgílio Várzea explicou em detalhes o significado do termo:

O porto de Florianópolis e todos os da baía do sul são abrigados e plácidos na maior parte do ano, em que reinam quase sempre os ventos do quadrante do norte; e só pela quadra invernosa é que eles, voltados para o sul como estão, se apresentam revoltos e com mar esparcelado, batidos pelos ventos desse lado que sopram às vezes furiosamente, acompanhados de aguaceiros ou pequenas tormentas. Em geral, porém, esses fenômenos meteorológicos são rápidos, dando e passando logo, perdurando contudo se o vento ronda para leste, o que produz então verdadeiras tempestades que tomam dali para o sul o nome característico e muito conhecido de lestadas. ${ }^{16}$

$\mathrm{Na}$ noite de 18 de abril, aquela em que Patápio deveria se apresentar, "a impetuosidade do vento [...] foi tal que derrubou muitas árvores em diversos pontos da cidade e nos subúrbios, causando também o desmoronamento de muros e cercas", registrou O Dia. ${ }^{17}$

Se o clima adverso já era difícil de ser enfrentado pelos nativos, para Patápio havia o agravante de não estar habituado ao frio. Na faixa etária dele, contudo, não era comum sucumbir à gripe. Dos 16 homens entre 20 e 30 anos que morreram em Florianópolis no primeiro semestre de 1907, apenas dois foram vitimados pela doença. A grande causa mortis nessa faixa etária era a tuberculose pulmonar, com oito casos no período. Entretanto, o problema de saúde enfrentado pelo flautista podia ser de outra natureza, não diretamente relacionada ao clima - uma infecção intestinal, por exemplo. Ou, como diziam os boatos da época, um envenenamento.

A cidade deixava a desejar em termos de saúde pública, conforme admitiam as próprias autoridades responsáveis pela área. Famílias que dispunham de melhores condições financeiras passaram a adquirir chácaras em locais afastados do centro para escapar dos riscos causados

\footnotetext{
16 VÁRZEA, 1985, p. 132.

17 O Dia, 20/04/1907, referindo-se a acontecimentos de "anteontem".
} 
pela falta de saneamento. Somente em 1909, dois anos depois da morte de Patápio, as primeiras redes de água de Florianópolis seriam assentadas. Havia grande preocupação com a propagação de doenças contagiosas, como demonstra uma reportagem do jornal O Dia, publicada logo acima de uma nota sobre o estado de saúde de Patápio - levando até a supor que os assuntos eram correlatos:

Males contagiosos - Estamos informados de que o ativo e zeloso sr dr Henrique Chenaud, digno Inspetor de Saúde, está empregando todos os meios a seu alcance para que as moléstias contagiosas não se propaguem nesta capital, ora mandando fazer rigorosas desinfecções nas casas onde falecem pessoas afetadas de moléstias infecto-contagiosas, ora providenciando, logo em seguida, sobre a respectiva limpeza das mesmas casas. Este interesse tomado por tão distinto facultativo é digno de louvor e pedimos ao público que o coadjuve, informando-o dos casos de que tiver conhecimento, a fim de que possa ele obter o fim desejado. A Inspetoria de Saúde fará também desinfecção nas casas deixadas por pessoas afetadas de tais moléstias, desde que tenha ciência do ocorrido. ${ }^{18}$

Intrigada sobre o mal que atingira o flautista, a cidade acompanhou de perto a evolução do quadro. A expectativa inicial era a de que ele, jovem e saudável, conseguiria se restabelecer rapidamente. $\mathrm{O}$ espetáculo chegou a ser anunciado para o sábado, dia 20, e depois para o domingo, 21, até ser postergado sem previsão de data. ${ }^{19}$

\section{Os acordes da memória}

Na manhã de sábado, dia 27, dois dias após a morte de Patápio, foi rezada na Catedral de Florianópolis uma missa em intenção à memória do flautista, encomendada por uma comissão de jovens da cidade. A solenidade contou com a presença maciça de integrantes das famílias mais tradicionais e autoridades de todo tipo - músicos, religiosos e representantes de instituições como Correios, Estação Telegráfica e consulados de outros países. A banda de música do Corpo de Segurança

\footnotetext{
18 O Dia, 19/04/1907.

19 O Dia, 21/04/1907.
} 
estava outra vez presente, como no enterro. Também no Rio de Janeiro houve uma missa, em 6 de maio de 1907, quase duas semanas após a morte de Patápio, mandada rezar na Igreja de São Francisco de Paula por um grupo de amigos do flautista. Durante a cerimônia, Francisco Braga regeu a orquestra que, acompanhada pelos barítonos J. de Larrigue de Faro e Rossi, executou a composição Evocação, de Patápio.

Ainda em meio à comoção pelo ocorrido, a Sociedade Literária e Recreativa Catarinense, um grupo de moças de Florianópolis, organizou uma campanha de arrecadação para a construção de um mausoléu para Patápio, iniciativa à qual Laly Mafaldi se referiu ao visitar a redação do jornal O Dia. A Sociedade promoveu na noite de quinta-feira, 9 de maio de 1907, no salão do Clube 12 de Agosto - o mesmo em que Patápio realizaria seu espetáculo -, uma sessão literária e um concerto, eventos cuja renda seria revertida em prol do projeto do mausoléu. Antes das apresentações musicais (incluindo a do maestro Adolfo Melo, que tocou o Carnaval de Veneza ao violino), o "jovem bacharelando" Fúlvio Aducci aproveitou mais uma vez para discursar - com "arroubos de eloquência e em frases rutilantes, discorreu admiravelmente sobre o talento de Patápio Silva", como descreve novamente o cronista de $\mathrm{O} \mathrm{Dia.} .^{20} \mathrm{O}$ dinheiro arrecadado teve outras destinações, pois o projeto do mausoléu não chegou a ser realizado.

No início de novembro de 1907, o pai de Patápio, o barbeiro Bruno da Silva, chegou a Florianópolis para receber o espólio do filho, incluindo a famosa flauta. Depois de uma semana na cidade, Bruno regressou ao Rio de Janeiro, acompanhado por Laly Mafaldi, que parece ter permanecido em Florianópolis ao longo dos seis meses que se seguiram à morte de Patápio. ${ }^{21}$ Infelizmente não foi possível apurar as razões dessa longa permanência, mas o fato de ter retornado no mesmo navio de Bruno reforça a evidência de que havia entre Patápio e Laly um vínculo maior do que o mero coleguismo artístico.

Os bens de Patápio, incluindo a flauta de prata, permaneciam retidos em Florianópolis porque havia dívidas com o Hotel do Comércio e a empresa Ortiga \& Fernandes, que realizou o enterro - o que contraria, portanto, a versão de que os custos do funeral haviam sido bancados

\footnotetext{
20 O Dia, 12/05/1907.

21 O Dia, 10/11/1907.
} 
pelo governo do estado de Santa Catarina, divulgada nos dias seguintes à morte de Patápio. A dívida com a funerária foi paga pela arrecadação promovida por Tiago da Fonseca, do jornal O Dia, veículo que pertenceria à corrente política do suposto rival de Patápio. Mais de um mês depois da visita do pai do músico a Florianópolis, O Dia contava que havia sido entregue à empresa Ortiga \& Fernandes a quantia de 202 mil réis - para efeito de comparação, a assinatura anual do jornal, que era diário, custava 18 mil réis. ${ }^{22}$

Os restos mortais do flautista foram exumados no início de agosto de 1915 para serem remetidos à família, que os pedira. Tais informações constam nos registros do arquivo do cemitério de Florianópolis. Esses registros revelam ainda que, ao ser aberta a sepultura, o coveiro Nestor Machado encontrou nela uma medalha de ouro com os dizeres Recordação de Batatais, 22/06/906 e Homenagem ao flautista Patápio. A medalha e os restos mortais do flautista foram entregues, em 18 de dezembro de 1915, ao procurador do pai em Florianópolis, o também barbeiro Alberto Correia, proprietário do Salão Brasil, instalado à Praça XV de Novembro. ${ }^{23}$

Patápio estaria, desde então, sepultado no Cemitério São Francisco Xavier, no Rio de Janeiro - no qual não foi possível encontrar registro que permitisse localizar seu túmulo. De qualquer forma, a transferência dos restos mortais pôs fim ao inesperado vínculo de oito anos entre o flautista e a pequena cidade que não o viu tocar. Mas a memória da impressionante trajetória e do imenso talento musical continua a encantar todos os que têm a oportunidade de conhecer a obra e a vida de Patápio.

\section{Fontes}

ARQUIVO HISTÓRICO MUNICIPAL DE FLORIANÓPOLIS. Fundo Cemitério Público. Série Terrenos de Cemitério. Sub-série Termos de arrendamento ou venda, ano 1899 a 1921, n. 3, caixa 1, p. 24.

\section{PERIÓDICOS}

Gazeta de Notícias

22 O Dia, 27/12/1907.

23 ARQUIVO HISTÓRICO MUNICIPAL DE FLORIANÓPOLIS. Fundo Cemitério Público. Série Terrenos de Cemitério. Sub-série Termos de arrendamento ou venda, ano 1899 a 1921, n. 3, caixa 1, p. 24. 


\begin{tabular}{|c|}
\hline O Dia \\
\hline 14/04/1907. \\
\hline 17/04/1907. \\
\hline 19/04/1907. \\
\hline 20/04/1907. \\
\hline 21/04/1907. \\
\hline 24/04/1907 (boletim extra). \\
\hline 25/04/1907. \\
\hline 27/04/1907. \\
\hline 12/05/1907. \\
\hline 10/11/1907. \\
\hline 27/12/1907. \\
\hline O Estado \\
\hline 3/08/1977. \\
\hline 21/08/1977. \\
\hline Reforma \\
\hline 18/04/1907. \\
\hline 25/04/1907. \\
\hline
\end{tabular}

\section{Referências}

ABREU, Martha. Meninas perdidas: os populares e o cotidiano do amor no Rio de Janeiro da Belle Époque. Rio de Janeiro: Paz e Terra, 1989.

EDMUNDO, Luiz. O Rio de Janeiro do meu tempo. Rio de Janeiro: Imprensa Nacional, 1938.

FRANCESCHI, Humberto Moraes. A Casa Edison e seu tempo. Rio de Janeiro: Sarapuí, 2002.

MENEZES, Cícero. Patápio Silva. Rio de Janeiro: Americana, 1953.

MENSAGEM LIDA PELO EXMO. CEL. GUSTAVO RICHARD, Governador do Estado, na sessão de abertura do Congresso Representativo, Florianópolis: Gab. Typ. d'O Dia, 1907, p. 13. 
MOURA, Roberto. Tia Ciata e a Pequena África no Rio de Janeiro. Rio de Janeiro: Funarte, 1983.

NECKEL, Roselane. A República em Santa Catarina: modernidade e exclusão (1889-1920). Florianópolis: Editora da UFSC, 2003.

PAOLA, Andrely Quintella; GONSALEZ, Helenita Bueno. Escola de Música da Universidade Federal do Rio de Janeiro - 150 anos. Rio de Janeiro: UFRJ, 1998. PINTO, Alexandre Gonçalves. O choro: reminiscências de chorões antigos. Rio de Janeiro: 1936 (Funarte, 1977).

RAMOS, Átila. Memória do saneamento desterrense. Florianópolis: Casan, 1986.

RIO, João do. A alma encantadora das ruas. Rio de Janeiro: Organizações Simões, 1952.

SOUSA, Abelardo. O mestre-escola viaja no tempo. Florianópolis: Governo do Estado de Santa Catarina, 1978.

SOUZA, Maria das Graças Nogueira de; PEDROSA, Henrique; PANTOJA, Selma Alves; CECHINE, Sinclair Guimarães. Patápio - músico erudito ou popular? Rio de Janeiro: Funarte, 1983.

TINHORÃO, José Ramos. Os sons que vêm da rua. 2. ed. revista e ampliada. São Paulo: Editora 34, 2005.

VÁRZEA, Virgílio. Santa Catarina: a ilha. Florianópolis: Lunardelli, 1985.

VASCONCELOS, Ari. Panorama da música brasileira na Belle Époque. Rio de Janeiro: Livraria Sant'anna, 1977.

VERISSIMO, Erico. Solo de clarineta: memórias. Porto Alegre: Globo, 1973. 


\title{
|| Capítulo 12 ||
}

\section{Clubes e associações de afrodescendentes na Florianópolis das décadas de 1930 e 1940}

\author{
Maria das Graças Maria
}

No Natal de 1933, um grupo de amigos moradores da Rua Chapecó, na Agronômica, decidiu fundar um clube recreativo ao qual deram o nome de União Recreativa 25 de Dezembro. $O$ ato da fundação partiu de Ramiro Farias, natural de Alto Biguaçu. Ele e Tertuliano Fernandes, procedente do Paraná, buscavam um espaço onde pudessem se divertir sem que tivessem que se deslocar para outros bairros.

Nicomedes Ferreira contou em entrevista: "Da primeira diretoria do 25 de Dezembro participaram, além daquele grupo de amigos que fundaram o clube, Epaminondas, Vicente de Carvalho, o primeiro presidente, José Capistrano, o tesoureiro e Leovegildo Luiz da Silva, o secretário". ${ }^{1}$ Eram todos afrodescendentes, e o clube foi, durante muito tempo, espaço exclusivo de diversão da população afrodescendente, onde não era permitida a entrada de pessoas brancas na pista de dança. Brancos, só no bar.

Fernando Henrique Cardoso e Octávio Ianni, no livro Cor e mobilidade Social em Florianópolis, usaram os clubes como espaços privilegiados para estudar as relações raciais na cidade. Em entrevistas com habitantes afrodescendentes, todos já mais velhos durante a pesquisa de campo que conduziram, em meados da década de 1950, Cardoso e Ianni apuraram que houve uma sequência quase ininterrupta do que chamaram "clubes

1 Entrevista concedida à autora por Nicomedes Ferreira (83 anos), em Florianópolis, novembro de 1994. 
de negros e mulatos" desde a abolição da escravidão. Mas destacaram que a única tentativa de fundar um clube que congregasse o que classificaram como brancos, mulatos e negros foi fracassada: fundado no morro do Chapecó, na Agronômica, o Aimoré Recreativo Esporte Clube teria durado poucos meses. Entre os motivos alegados em entrevistas aos sociólogos paulistas, o fato de que as moças consideradas brancas não aceitavam dançar com os rapazes considerados mulatos ou negros. Isso teria sido em 1933 e ainda era lembrado com detalhes em 1955. Dessa experiência frustrada teriam nascido a União Recreativa 25 de Dezembro e o Clube Recreativo Concórdia. Do 25 de Dezembro, Cardoso e Ianni testemunharam:

Esse clube de negros e mulatos, aliás, é dos melhores organizados da comunidade, entre aqueles elementos de cor. Mantém as mesmas normas rígidas estabelecidas na década de 1930, quando foi fundado. Não aceita brancos como sócios; apenas visitantes, que são autorizados a fazer gastos no bar, mas não dançar. ${ }^{2}$

Este capítulo busca reconstituir a história da fundação e do funcionamento de dois desses clubes recreativos que congregavam segmentos das populações afrodescendentes de Florianópolis nas décadas de 1930 e 1940. Baseia-se numa pesquisa mais ampla, que teve por objetivo analisar as experiências cotidianas das populações afrodescendentes e a constituição de seus territórios na cidade de Florianópolis nas décadas de 1930 e 1940. Através das atas de reuniões das diretorias dos clubes, da memória oral de seus integrantes e familiares e também através de fotografias, pudemos perceber o caráter multirracial impresso à cidade. Esta era marcada pelo preconceito racial, que se refletia na segregação dos espaços, verdadeiros territórios étnicos marcados pela interdição silenciosa, onde as diferenças étnicorraciais definiam os lugares de cada grupo. Os clubes são espaço privilegiado para essa observação.

\section{A constituição de “territórios negros” em Florianópolis}

A Florianópolis do início do século XX foi, assim como outras capitais brasileiras, palco de políticas públicas que resultaram na espacialização

2 CARDOSO; IANNI, 1960, p. 180. 
da pobreza na cidade. Em nome da higienização, do saneamento e da modernização, reformas urbanas afastaram as camadas populares de áreas que historicamente ocupavam. As evidências disso são o gradual embranquecimento dos espaços centrais das cidades e a formação de bairros populares periféricos desprovidos de infraestrutura urbana. Esse processo estabeleceu inúmeras barreiras que dificultaram a ascensão social das populações pobres, predominantemente de origem africana, impedindo também que gozassem de direitos fundamentais como educação, moradia digna, saneamento urbano, transporte público, assistência médica etc. A maioria dos afrodescendentes naturais da cidade ou migrantes que passaram a habitar os morros da cidade, tanto na Ilha quanto no continente, desde o início do século XX, viviam em condições precárias e em situação instável, uma vez que todos os investimentos em infraestrutura eram canalizados para os bairros onde residia a população mais abastada.

O senhor Ramiro Farias teve que desmatar e abrir a Rua Chapecó, quando se instalou lá, na década de 1930. Seu filho Romélio lembrou que o pai tinha sido o primeiro morador da rua e que ficou conhecido entre seus colegas de trabalho como "negro do mato", ${ }^{3}$ de tanto mato que havia na região onde morava - hoje, o bairro da Agronômica. Ramiro trabalhava na estiva, na Standard Oil Company, ali instalada. Também trabalhou na construção da penitenciária e na empresa de Carl Hoepcke, mas logo que chegou à cidade, era empregado na casa dos Wendhausen, onde capinava, plantava e tratava de negócios na rua.

Os poderes públicos se manifestavam exercendo políticas de controle sobre os cidadãos. O trabalho, por exemplo, passou a ser um dos valores exigidos como distintivo de cidadania. A construção do ideal de homem brasileiro ocorreu num contexto político-ideológico no qual as diferenças raciais eram escamoteadas, acentuando ainda mais a invisibilidade dos não brancos. Com poucos recursos financeiros disponíveis, pois haviam abandonado seus locais de origem à procura de trabalho na cidade, os trabalhadores afrodescendentes viveram em Florianópolis as tensões comuns do meio urbano: desemprego, subemprego, discriminação e preconceito racial. A disputa no mercado de trabalho formal era acirrada e nela, saíam em desvantagem. Esse problema foi ainda maior para as mulheres afrodescendentes e pobres.

3 Entrevista concedida à autora por Romélio Farias, em Florianópolis, novembro de 1996. 
Apesar de algumas terem exercido as mais diferentes atividades na cidade e outras terem se destacado, ocupando posições como educadoras ou cargos políticos, como Antonieta de Barros - a primeira deputada estadual de Santa Catarina -, a maioria delas encontrou nas atividades informais a sua única fonte de renda. O trabalho doméstico era muito comum, porque as famílias mais ricas buscavam mulheres no interior e davam preferência às afrodescendentes para trabalhar em suas casas. Dialtina da Silva, residente em Alto Biguaçu esteve entre os migrantes que vieram do interior para se estabelecer em Florianópolis, como empregada doméstica. A senhora Marcolina Farias, esposa de Ramiro Farias, era parteira. E foi com essa atividade que passou a compor a renda familiar, ao lado do marido. Como lembrou sua filha, ela sempre era chamada para atender as mulheres da redondeza; às vezes, recebia em cortes de tecido ou outros produtos de quem não podia pagar em dinheiro. Destacase ainda que muitas mulheres, mesmo sem sair de casa, trabalhavam como engomadeiras, lavadeiras, costureiras, bordadeiras, atividades que acumulavam com o cuidado dos seus familiares. Muitas se serviam dos recursos que obtinham a partir destas atividades para investir na educação escolar de seus filhos.

Foi nesse contexto que as populações de origem africana da cidade construíram seus espaços de sociabilidade, sendo sempre marcados por uma pluralidade de práticas socioculturais, que imprimiam a determinados lugares o perfil de territórios negros. Locais de práticas religiosas, como terreiros de umbanda, eram espaços privilegiados de convivência para afrodescendentes. No entanto, tais práticas sofriam perseguição por parte da polícia, criminalizadas da mesma forma que os jogos de azar e a prostituição. A ialorixá Malvina, dirigente de um centro de umbanda no bairro do Estreito, sofreu inúmeras perseguições e punições da polícia, sendo frequente presa por conta do exercício das práticas religiosas. Locais de culto católico, blocos carnavalescos, escolas de samba e clubes recreativos também constituíram territórios negros. Agora, voltemos aos clubes.

\section{A sociabilidade segregada}

Uma das memórias mais marcantes entre os entrevistados é a do footing na praça XV de Novembro. Footing, na língua inglesa, significa 
andar, caminhar, e era muito usada nas décadas de 1930 e 1940 para definir o tipo de passeio confinado a um lugar específico. Era lugar de encontros, de troca de olhares, de namoros. Maria do Espírito Santo, com 82 anos na época da entrevista, nasceu em Florianópolis na década de 1930; contou que quando ainda era solteira, costumava frequentar o footing da Praça $\mathrm{XV}$, onde muitas vezes, segundo ela, arrancava suspiros de admiração dos moços, por sua beleza. Ela comentou que recebia muitos galanteios: "No Carnaval, eu sempre namorava homens brancos, depois, eles queriam continuar o namoro e eu dizia: acabou, foi só no carnaval, tu foste a minha fantasia". ${ }^{4}$ A palavra provavelmente guardava um duplo sentido: não só o namoro era fugaz e descartável como uma fantasia de carnaval, mas também era percebido como incompatível com a realidade. O footing foi a expressão mais explícita da presença dos territórios étnicos nas cidades e da divisão e hierarquização espacial e social no contexto urbano. Representava a construção de espaços públicos de sociabilidade no centro da cidade, tendo a rua como palco da discriminação e do preconceito social, porque constituiu territórios distintos para a caminhada de brancos, afrodescendentes, pobres e ricos. Conforme lembram alguns entrevistados, como Guilherme Silveira, da Rua Felipe Schmidt até a frente da Confeitaria do Chiquinho, esquina com Rua Trajano, ficavam os jovens da elite branca. Da Rua Arcipreste Paiva, ao lado da Catedral, passando pela calçada da Praça XV de Novembro e pela calçada do Palácio do Governo, em direção à Praça Fernando Machado, circulavam os jovens afrodescendentes, enquanto a parte interior da Praça XV era o lugar destinado às jovens prostitutas. Era a expressão da sociedade social e racialmente hierarquizada.

A separação também se verificava nos clubes. Os habitantes do Morro do Chapecó tinham, a partir de 1933, dois clubes. Mas participar dos bailes de um ou outro não era uma escolha individual. Como vimos, no salão de baile do 25 de Dezembro, só entravam aqueles identificados como "negros" ou "mulatos". O Clube Recreativo Concórdia, fundado na mesma época, era espaço de entretenimento exclusivo para aqueles considerados "brancos". Maria do Carmo de Souza, associada do 25 de Dezembro, lembrou no seu depoimento: "No meu tempo de 25, os brancos

\footnotetext{
4 Entrevista concedida à autora por Maria do Espírito Santo Ferreira, primeira rainha da União Recreativa 25 de Dezembro, em Florianópolis, novembro de 1994.
} 
não podiam entrar, se entrassem dava briga. Cada um no seu clube. E no Concórdia, a gente só podia espiar os bailes do lado de fora" ${ }^{5}$ Os critérios utilizados pelo 25 de Dezembro para regulamentar a entrada de brancos demonstram que as normas vigentes no clube respondiam a práticas presentes nas relações cotidianas. Como reações ao racismo que sofriam no cotidiano da cidade, os integrantes do clube adotavam uma postura política ao redefinir o espaço do clube como exclusivo de não brancos. Tal postura conferia a eles identidade étnicorracial, dando singularidade e garantindo a visibilidade daquele território negro.

O Clube Recreativo Brinca Quem Pode foi constituído a partir do bloco carnavalesco que tinha o mesmo nome, também em meados da década de 1930. Olga, ex-rainha do Brinca e também ex-secretária, lembrou em entrevista que "a sede do clube estava localizada na Rua Conselheiro Mafra, no Centro, próxima ao jornal O Estado". ${ }^{6}$ Assinalou que, mais tarde, "o clube se transferiu para uma sede própria, construída onde era, à época da entrevista, o Clube dos Motoristas, na Avenida Tico-tico, atual rua Clemente Rovere, próxima ao Instituto Estadual de Educação". Ela lembra que o nome do governador Nereu Ramos estava inscrito nas pilastras do clube, possivelmente por ter dado apoio à construção e manutenção da associação. A sede teria sido mais tarde hipotecada.

Algumas memórias indicam que havia circulação entre os frequentadores dos dois clubes, e que as experiências pessoais contribuíram para dar significados renovados àqueles espaços. O jovem casal Guilherme e Adalgisa, por exemplo, se conheceram num baile no 25 de Dezembro. Foi ele que lembrou: "Eu costumava ir sempre ao 25 de Dezembro, e ela no Brinca Quem Pode. Um dia, Adalgisa resolveu dançar no 25 de Dezembro, nos conhecemos, namoramos e acabamos casando. Naquele lugar tinha muitas moças, mas foi ela que eu mais gostei para casar". 8

5 Entrevista concedida à autora por Maria do Carmo de Souza, em Florianópolis, setembro de 1995.

6 Entrevista concedida à autora por Olga, ex-secretária e ex-rainha do Brinca Quem Pode, em Florianópolis, novembro de 1996.

7 Entrevista concedida à autora por Olga em Florianópolis, novembro de 1996.

8 Entrevista concedida à autora por Guilherme Silveira, em Florianópolis, novembro de 1995. 
Ao contrário da União Recreativa 25 de Dezembro, o Brinca Quem Pode não impedia a entrada de brancos, apesar de seus frequentadores serem, na maioria, afrodescendentes. A presença do governador Nereu Ramos no clube era frequente, principalmente nos bailes de gala. Isso refletia os laços políticos existentes entre o governo e a diretoria: José Ribeiro dos Santos, presidente do clube, era filiado ao Partido Liberal Catarinense, do qual o chefe do executivo era fundador e primeiro presidente. José Ribeiro era mecanógrafo (técnico de máquinas de escrever e calcular), foi técnico de futebol e o primeiro vereador negro da cidade. A presença do governador numa sociedade recreativa que não era local de frequência dos membros da elite branca da cidade era principalmente motivada por questões políticopartidárias. José Ribeiro Santos, como presidente do clube, provavelmente agia como cabo eleitoral de Nereu Ramos e angariava favores pessoais, ao mesmo tempo em que agia em defesa daquele espaço de maioria afrodescendente diante do poder público.

A criação de associações beneficentes e recreativas com recortes espaciais (associações de bairro), laborais (grêmios de trabalhadores) ou étnicos (clubes das comunidades imigrantes, por exemplo) foi muito comum nas décadas de 1930 e 1940. Mas os rótulos enganam. Os clubes recreativos são a demonstração incontestável da diversidade dos sujeitos históricos que conviviam naqueles espaços e viviam naquelas comunidades. O rótulo "clubes e associações negros" não dá conta da complexidade das experiências vividas por seus integrantes.

\section{Papéis masculinos e femininos?}

A diretoria executiva dos clubes era toda constituída por homens afrodescendentes e as reuniões semanais eram por eles presididas. Como veremos adiante, as mulheres representavam a "ordem" e a "moralidade" nos espaços do clube, através das funções do grêmio feminino, mas nunca integravam a diretoria. Silvio de Souza, presidente do 25 em várias gestões, comentou que "desde a sua fundação, até mais ou menos a década de 60, a diretoria do 25 de Dezembro era composta só de negros. [Era] o único clube da cidade que tinha uma diretoria só de homens da raça".

\footnotetext{
9 Entrevista concedida à autora por Silvio de Souza, presidente da União Recreativa 25 de Dezembro por várias gestões; em Florianópolis, 1994.
} 
Apesar da importância da atuação das mulheres do grêmio feminino, a organização e a direção destas entidades estava sempre sob o controle dos homens. Não só as atas das reuniões como também os registros fotográficos demonstram a liderança masculina, reflexo dos valores dominantes no imaginário social, no qual a dominação sexual continuava a ser exercida da forma tradicional, impondo forte discriminação contra a atuação pública das mulheres.

As construções de gênero reforçavam ainda mais as desigualdades que, no espaço dessas sociedades recreativas, se configuravam principalmente nas atribuições de cada grupo sexual. Os homens negros exerciam as práticas sexistas tais quais os homens brancos. Se os homens e mulheres de ascendência africana, juntos, eram alvos de preconceito racial, nas relações sociais cotidianas, esses sujeitos não diferiam dos modelos de dominação masculina branca. Porque, como diz Fátima Oliveira "o problema é que antes de ser discriminado racialmente, o homem negro faz parte do gênero masculino, portanto devidamente adestrado para a prática da superioridade". ${ }^{10}$

No interior dos clubes citados, mulheres ehomens afrodescendentes viveram as mais diversificadas funções, e não caberia identificar se tais funções obedeciam aos papéis sexuais tradicionais, uma vez que nem sempre as atividades atribuídas oficialmente às mulheres nesses espaços de sociabilidade foram, na prática, o que elas realmente exerceram. Como apontou Joana Maria Pedro,

as mulheres negras vivenciaram em muitas ocasiões papéis que não eram associados a seu gênero, pois assumiam a manutenção da casa, a guarda dos filhos na ausência de um companheiro e o desempenho de trabalhos que entre a população branca eram exercidos por homens. ${ }^{11}$

Nos clubes e associações, elas destacaram-se principalmente pela participação nos grêmios femininos, servindo como apaziguadoras ou procurando angariar certa respeitabilidade, o que permitiu a valorização daqueles territórios perante a comunidade. Olga, secretária do grêmio

10 OLIVEIRA et al., 1995.

11 PEDRO, 1994, p. 42. 
feminino do Brinca Quem Pode, teve sério conflito com José Ribeiro, diretor da entidade, quando não permitiu que um tenente do exército trouxesse sua empregada para dançar no clube:

Uma vez, não sei se era major ou tenente do exército, que tinha uma empregada mocinha bonitinha [...] Eu era secretária do grêmio feminino do Brinca e vieram me dizer que ela não podia entrar [...] apesar de ele dizer para todo mundo que ela era sua afilhada [...] Mandei chamá-la lá e barrei a entrada dela [...] Ele disse: "Ela pode dançar, e ela vai dançar". Eu: "Duvido que ela vai dançar, só se passar por cima de mim". E depois de muita discussão o presidente do clube disse: "Ela vai dançar só por hoje". Eu disse: "Não senhor. Lei é lei. Nós somos a lei, ela não pode dançar". Ele era casado e a moça, empregada dele. Ela era mulata, e ele era branco. ${ }^{12}$

O conflito entre secretária e presidente do clube revela que algumas mulheres assumiam o poder, ainda que temporariamente, apoiandose nos estatutos e contrariando as regras da dominação masculina. As mulheres também atuaram em atividades promocionais nos momentos de crise financeira, para efetuar, por exemplo, o pagamento das orquestras que "abrilhantavam" os bailes. As mulheres afrodescendentes exerceram uma pluralidade de papéis, no entanto, isso não as levou a conquistas que representassem mudanças na hierarquia sexual naquele espaço.

Isso fica evidenciado nas histórias das muitas mulheres eleitas rainhas e princesas para representar aquelas sociedades recreativas, tornando-se parte da história daqueles territórios negros. Se, por um lado, o ritual da coroação era motivo de vaidade, envolvendo as moças eleitas e os seus familiares, todas aquelas festividades também ocultavam posturas sexistas. Ao lado da rainha, havia também as princesas. A primeira rainha do 25 de Dezembro foi Maria do Espírito Santo Ferreira, eleita duas vezes consecutivas. Foi eleita com 50 votos, num total de 60 votos. $\mathrm{Na}$ época, não havia coroação. Foi somente a partir da terceira rainha que as candidatas eleitas passaram a ser coroadas. Os bailes de coroação das rainhas eram momentos de destaque, quando as pessoas usavam trajes formais, de festa. Era comum a escolha da rainha ocorrer diante de um corpo de jurados; outras vezes, as candidatas recebiam do clube blocos

12 Entrevista concedida à autora por Olga, em Florianópolis, novembro de 1996. 
para vender votos, e quem vendesse o maior número seria a eleita. Isso envolvia toda a família que queria que suas filhas recebessem os títulos. Exibia-se a beleza das mulheres que, como rainhas, passavam a ser os ícones do clube; no entanto, as discriminações sexistas permaneciam, e a coroação como rainhas da beleza reforçava ainda mais as construções de gênero. O título não modificava estas relações na prática cotidiana, pelo contrário, reforçava-as. Porém, tais mulheres ajudavam a promover a visibilidade do clube na cidade e em outros lugares. Era comum, por exemplo, a rainha visitar outros municípios do estado, em festividades que envolviam outros bailes de coroação.

\section{Normas de conduta}

Através de grêmios femininos como o Flor de Maio, fundado em 1934 (no 25 de Dezembro), as mulheres exerciam a função específica de fiscais de salão, guardiãs da ordem, cujo principal objetivo era a constante vigilância sobre os casais durante os bailes. Era proibido aos casais beijarem-se no salão. Também era proibido dançar em estado de embriaguez. Além disso, as moças solteiras não podiam sair acompanhadas de homens que não fossem da sua família, mesmo que fossem seus namorados. Era comum, naquele tempo, que as mulheres solteiras andassem acompanhadas de mulheres mais velhas, dentro e fora dos clubes. Era assim quando Olga foi secretária do Brinca Quem Pode, conforme lembrou em entrevista.

Esse controle do comportamento feminino em nome da moralidade não recaía apenas sobre as mulheres afrodescendentes, era comum também para as mulheres brancas, refletindo os valores morais dominantes à época. Ao defender a moralidade dentro do clube, as fiscais e todos os frequentadores estavam fazendo uso dos seus valores culturais, presentes no seu contexto histórico. A honra familiar dependia do comportamento das mulheres, da manutenção da virgindade até o casamento, da fidelidade ao marido, da obediência ao papel de mãeesposa dedicada. 
As atas das reuniões da União Recreativa 25 de Dezembro são reveladoras de ocorrências de controle do comportamento feminino, tal como o acontecido em 1949:

Com a palavra, o membro da comissão trazendo ao conhecimento o inconveniente para a sociedade, com o afastamento do recinto social antes da hora do término do baile, fazendo-se acompanhar por cavalheiros não previstos no quadro, no que se refere às senhoritas: Zilá Maria, Osvaldina de Tal e Elizabete Penedo. O presidente expôs o assunto ao critério da mesa e a mesa resolveu a seguinte punição: chamá-las a atenção para a repreensão e avisálas que acham-se suspensas por um baile e, se continuar assim procedendo, a diretoria tomará outras medidas". ${ }^{13}$

No caso das associações recreativas integradas e frequentadas por afrodescendentes, essa vigilância sobre o comportamento de seus membros era também uma forma de construir respeitabilidade e garantir a existência do território negro, uma vez que os estereótipos desqualificavam as populações de ascendência africana e seus valores culturais como "incivilizados", desordeiros e promíscuos. Demonstrar respeitabilidade era uma estratégia das populações afrodescendentes contra a discriminação racial não apenas em Florianópolis, mas em todo o Brasil e mesmo nos Estados Unidos, onde o preconceito era institucionalizado.

Os participantes das associações recreativas partilhavam da preocupação com a respeitabilidade e, assim, impunham obediência a comportamentos de "moralização" no espaço dos clubes e nas ocasiões festivas da comunidade. Além de fiscalizar o comportamento dos frequentadores das festas, as mulheres do grêmio garantiam que todos estivessem decentemente vestidos. O bem vestir fazia parte das normas das associações recreativas e era expressão de distinção para as pessoas que frequentavam o 25 de Dezembro e o Brinca Quem Pode. Os cuidados com o traje nas dependências dos clubes revelam outra forma de controle, para a manutenção de boas normas de convivência e respeitabilidade. Os integrantes, quando entrevistados, lembravam-se dessas normas como uma forma de resistência aos estereótipos que costumavam representar

13 ATA de reunião da União Recreativa 25 de Dezembro, ano de 1949. 
o negro sujo e malvestido, desqualificando a estética das populações de ascendência africana. Por outro lado, as pessoas também eram atraídas pelo impacto da moda, porque viviam num contexto urbano em que o padrão de bem vestir era um dos critérios que lhes conferia status e dignidade. Mesmo as pessoas com baixo poder aquisitivo procuravam trajar-se dentro dos rigores da moda. Os registros fotográficos da época evidenciam o bem trajar das mulheres e homens negros. Os depoimentos registrados também deixam perceber o valor social de tais questões: Maria do Espírito Santo, ex-rainha do 25, contou que sua mãe gostava de se vestir com veludo, seda e também usava chapéus. Rogério Farias enfatizou a importância do uso do terno como traje convencional masculino: "Nos bailes de gala do clube 25 de Dezembro, só era permitido dançar de terno". ${ }^{14}$ Em relação ao Brinca Quem Pode, Olga (secretária do grêmio feminino) lembrou:

Não era qualquer negro que entrava no Brinca não. Os homens tinham que dançar de sapato engraxado ou envernizado. Não podiam dançar em manga de camisa. Nos bailes, as mulheres só podiam dançar de vestido comprido. Quando não ia de vestido comprido, não dançava. E os homens, de terno azul marinho. ${ }^{15}$

Os valores socioculturais interferem nas relações estabelecidas entre os sujeitos históricos sejam eles identificados como brancos ou afrodescendentes. Adotar valores da elite branca significava, para as populações afrodescendentes, uma estratégia de busca de convivência e sobrevivência. Ainda assim, as relações entre mulheres e homens afrodescendentes e deles na sociedade foram permeadas por muitos conflitos, dentro e fora daqueles territórios. Nas décadas de 1930 e 1940, a censura governamental atuava de forma implacável sobre as mais diferentes atividades culturais. Os afrodescendentes e seus territórios étnicos, pela sua diversidade cultural, tornaram-se o principal alvo de tais políticas reguladoras que, aliadas ao preconceito racial vigente, promoviam a desvalorização social destas populações ao desqualificar as suas práticas culturais. Expressões como algazarra, bagunça, intriga

14 Entrevista concedida à autora por Rogério Farias, em Florianópolis, novembro de 1996.

15 Entrevista concedida à autora por Olga, em Florianópolis, novembro de 1996. 
e embriaguez eram atribuídas às atitudes dos afrodescendentes. A ata de uma reunião da diretoria do 25 de Dezembro em 1949 testemunha essa preocupação: "De pé, com a palavra, o senhor presidente dá ciência à mesa de que havia feito um apelo aos associados e frequentadores desta sociedade sobre o comportamento na saída dos bailes, devido a intrigas e algazarras que perturbam o silêncio público". ${ }^{16}$

Vê-se como as normas reguladoras desses territórios negros eram plenas de ambiguidades, porque, paralelamente ao controle que exerciam sobre os associados, as sociedades recreativas também representavam formas de defesa dos associados contra arbitrariedades e ingerência dos poderes públicos.

\section{Considerações finais}

Os clubes União Recreativa 25 de Dezembro e Brinca Quem Pode, fundados na década de 1930, foram espaços onde as populações afrodescendentes puderam expressar emoções, gestos, ritmos e estabelecer uma diversidade de relações que revelam histórias marcadas por conflitos de gênero, raciais, culturais, políticos e socioeconômicos. Para além da cidade representada nos discursos, imagens e textos oficiais, as populações afrodescendentes construíram outras histórias, definiram outros espaços e revelaram outra imagem de Florianópolis. Os clubes, além de espaço de lazer, foram palco de acontecimentos diversos, como espaço político, de expressão, ressignificação de culturas, construção da identidade e conflitos étnicos. Tais sociedades foram também lugares de memória, nos quais foi estabelecida uma multiplicidade de relações; e nos quais uma pluralidade de poderes e tensões se configurou, a partir do estabelecimento das normas e códigos de "moralidade", que conferiam àqueles territórios perfis muito singulares.

As experiências que alguns segmentos das populações afrodescendentes viveram no interior daquelas entidades constituíram histórias que foram sendo tecidas a cada evento promovido por elas. As atas das reuniões forneceram alguns fragmentos da ação daqueles sujeitos históricos. Os acontecimentos que ficaram registrados na memória oral

16 ATA de reunião da diretoria da União Recreativa 25 de Dezembro; 1949. 
permitiram pensar a composição dos territórios. O clube foi, acima de tudo, um espaço onde as populações afrodescendentes do Morro do 25 ou do Tico-Tico puderam se expressar num contexto urbano específico.

Naqueles territórios, verdadeiros arquivos de história, foi possível perceber uma diversidade de papéis entre as mulheres afrodescendentes, demonstrando que as construções de gênero marcaram as relações sociais no interior dessas comunidades e também das sociedades recreativas. As normas de conduta nos clubes representavam, acima de tudo, as práticas

políticas que nortearam a organização desses lugares e faziam parte das estratégias deluta pela manutenção desses territórios. Alguns deles podem ser configurados como lugar de luta contra a discriminação e o racismo, antes da institucionalização do movimento negro nas décadas posteriores. Que aquele território da antiga Rua Chapecó seja hoje conhecido como Morro do 25 é testemunho da vitória daqueles que, no Natal de 1933, fundaram o clube, e de todos os que lutaram para a consolidação desse e de outros territórios como espaços de recreação, mas também de construção de cidadania, reinvenção de tradições e ressignificação de identidades, das práticas culturais, da luta contra o preconceito racial e a segregação espacial vivida entre as populações afrodescendentes em Florianópolis.

\section{Fontes}

ACERVO DA UNIÃO RECREATIVA 25 DE DEZEMBRO.

Atas da sessão da diretoria da União Recreativa 25 de dezembro, de 1949.

ENTREVISTAS (acervo da autora)

Guilherme Silveira, 70 anos, dezembro de 1995.

Maria do Carmo de Souza, setembro de 1995.

Maria do Espírito Santo Ferreira, dezembro de 1995.

Nicomedes Ferreira, 83 anos, novembro de 1994.

Olga (sobrenome não registrado), novembro de 1996.

Raulina Farias, filha de Ramiro e Marcolina Farias, dezembro de 1995.

Romélio Farias, filho de Ramiro e Marcolina Farias, novembro de 1996.

Silvio de Souza, novembro de 1994. 
CAMPOS, Cynthia Machado. Santa Catarina, 1930: da degenerescência à regeneração. Florianópolis: Editora da UFSC, 2008.

CARDOSO, Fernando Henrique; IANNI, Octávio. Cor e mobilidate social em Florianópolis. São Paulo: Nacional, 1960.

CARDOSO, Paulino de Jesus Francisco. A luta contra a apathia: estudos sobre a instituição do movimento anti-racista na cidade de São Paulo (1915-1931). Dissertação (Mestrado em História) - Pontifícia Universidade Católica, São Paulo, 1993.

CARDOSO, Paulino de Jesus Francisco; MORTARI, Cláudia. Territórios negros em Florianópolis no século XX. In: BRANCHER, Ana. História de Santa Catarina: estudos contemporâneos. Florianópolis: Letras Contemporâneas, 1999.

CORADINI, Lisabete. Praça XV: espaço e sociabilidade. Florianópolis: Letras Contemporâneas, 1995.

CUNHA, Olívia G.; GOMES, Flávio S. (Ed.). Quase Cidadão: histórias e antropologias da pós-emancipação no Brasil. Rio de Janeiro: Editora da FGV, 2007.

MARIA, Maria das Graças. Imagens invisíveis de Áfricas presentes: experiências das populações negras no cotidiano da cidade de Florianópolis (1930-1940). Dissertação (Mestrado em História) - Universidade Federal de Santa Catarina, Florianópolis, 1997.

OLIVEIRA, Fátima et al. A mulher negra na década: a busca de autonomia. Caderno Geledés, n. 05 (1995).

PEDRO, Joana Maria. Mulheres honestas e mulheres faladas: uma questão de classe. Florianópolis: Editora da UFSC, 1994.

. Relações de gênero na pesquisa histórica. Revista Catarinense de História, Florianópolis, v. 2, p. 35-44, 1994.

VEIGA, Eliane Veras da. Florianópolis: memória urbana. Florianópolis: Editora da UFSC/Fundação Franklin Cascaes, 1993. 


\section{Autores e organizadoras}

\section{Ana Carla Bastos}

Bacharel e licenciada em História pela Universidade Federal de Santa Catarina. Foi bolsista do projeto Arranjos de liberdade e de trabalho nos documentos cartoriais da Ilha de Santa Catarina no século XIX e do programa CAPES-FIPSE, pelo qual cursou um semestre na University of North Carolina (Charlotte, EUA). Atualmente, exerce a atividade de Técnica em Assuntos Educacionais na UFSC.

\section{Beatriz Gallotti Mamigonian}

Professora do Departamento de História da Universidade Federal de Santa Catarina. Doutora em História pela University of Waterloo (Canadá), se dedica à pesquisa e ao ensino na área de História da Diáspora Africana, tendo organizado duas coletâneas de biografias em parceria com Karen Racine - The Human Tradition in the Black Atlantic (Rowman and Littlefield, 2009) e The Human Tradition in the Atlantic World (Rowman and Littlefield, 2010) -, e publicado artigos em revistas acadêmicas e capítulos de coletâneas. Coordena, com Andréa Ferreira Delgado, o programa de extensão Santa Afro Catarina: educação patrimonial e a presença de africanos e afrodescendentes na Ilha de Santa Catarina.

\section{Claudia Mortari Malavota}

Professora do Departamento de História da Universidade do Estado de Santa Catarina. Doutora pela Pontifícia Universidade Católica do Rio Grande do Sul; dedica-se à pesquisa sobre a presença de africanos e afrodescendentes em Desterro, tendo publicado capítulos de livro e artigos em revistas acadêmicas.

\section{Elizabete Maria Espíndola}

Professora e vice-coordenadora do curso de História da Universidade do Vale do Sapucaí (Univas) e coordenadora do Laboratório de documentação Cartorial da Univas - LabDoc. Mestre em História Social pela Pontifícia Universidade Católica de São Paulo, atualmente desenvolve pesquisa de doutoramento pela Universidade Federal de Minas Gerais.

\section{Fabiane Popinigis}

Professora do Departamento de História da Universidade Federal Rural do Rio de Janeiro. Concluiu o doutorado na Universidade Estadual de Campinas em 2003 e 
é autora do livro Proletários de casaca - trabalhadores do comércio carioca (Editora da Unicamp, 2007). Concluiu o pós-doutorado na Universidade Federal de Santa Catarina em 2010, onde realizou pesquisa sobre o Primeiro Mercado Público de Desterro. Atualmente, desenvolve o projeto Trabalhadores no comércio ambulante de gêneros em Desterro e no Rio de Janeiro, século XIX.

\section{Fernanda Zimmermann}

Mestre em História pela Universidade Federal de Santa Catarina, tendo se dedicado a pesquisar a escravidão nas armações baleeiras e em regiões de abastecimento, como Ribeirão da Ilha e São Miguel. Foi bolsista do programa CAPES-FIPSE, pelo qual cursou um semestre na University of North Carolina (Charlotte, EUA), e atualmente é professora da educação básica.

\section{Henrique Espada Lima}

Professor do Departamento de História da Universidade Federal de Santa Catarina. Doutor em História pela Universidade Estadual de Campinas, publicou A micro-história italiana: escalas, indícios e singularidades (Civilização Brasileira, 2006), além de artigos e capítulos em coletâneas. Bolsista de Produtividade em Pesquisa (CNPq), atualmente estuda o lugar dos ex-escravos e seus descendentes no mundo do trabalho em Santa Catarina no século XIX.

\section{Jaime José dos Santos Silva}

Historiador, graduado pela Universidade Federal de Santa Catarina, onde cursa atualmente o mestrado em História. Seu texto nesta coletânea se baseia na monografia Sons que ecoavam no passado: as festas de origem africana em Desterro na primeira metade do século XIX, trabalho premiado no Concurso Nacional de Pesquisa sobre Cultura Afro-Brasileira, Comunidades Tradicionais e Cultura AfroLatina, ano de 2010, realizado pela Fundação Cultural Palmares. Atualmente, participa dos projetos Santa Afro Catarina: educação patrimonial e a presença de africanos e afrodescendentes na Ilha de Santa Catarina e Acervo documental de Florianópolis no Banco de Dados Mundial sobre Fortificações.

\section{Joseane Zimmermann Vidal}

Professora de História da Rede Municipal de Florianópolis. Concluiu o Mestrado em História do Brasil na Universidade Federal de Santa Catarina em 1996. Trabalhou como Assessora Pedagógica para a área de História na Secretaria Municipal de Educação, no período de 2006 a 2010. 


\section{Maria das Graças Maria}

Professora aposentada da rede estadual de ensino de Santa Catarina e mestre em História pela Universidade Federal de Santa Catarina. Seu texto nesta coletânea se baseia em sua dissertação Imagens Invisíveis de Áfricas Presentes: Experiências das populações negras no cotidiano da cidade de Florianópolis (1930-1940).

\section{Martha Rebelatto}

Doutora em História pela Universidade Federal de Minas Gerais, com estágio na Stanford University e mestre em História pela Universidade Federal de Santa Catarina. Publicou os artigos Fugas e quilombos na Ilha de Santa Catarina, século XIX, na revista Afro-Ásia (2007) e Uma saída pelo mar: rotas de fuga escrava em Santa Catarina no século XIX, na Revista de Ciências Humanas/UFSC (2006). Atualmente, se dedica ao estudo das atividades econômicas envolvendo trabalhadores escravos no Termo da Vila de Santa Bárbara, Minas Gerais, durante o século XIX.

\section{Maurício Oliveira}

Jornalista formado pela Universidade Federal de Santa Catarina, com mestrado em História Cultural pela mesma instituição. Atuando como freelancer desde 2003, escreve com regularidade para publicações de circulação nacional. Foi coordenador de produção da Editora Contexto, em São Paulo, e é autor dos livros Chacina em Anhatomirim; Ponte Hercílio Luz - Tragédia Anunciada; Patápio Silva - O Sopro da Arte e Amores Proibidos na História do Brasil. É o jornalista responsável pelo texto final das apostilas de História e Geografia da coleção preparatória para o Enem 2012, da Editora Abril.

\section{Rafael da Cunha Scheffer}

Doutor em História Social pela Universidade Estadual de Campinas e mestre em História pela Universidade Federal de Santa Catarina. Publicou A conturbada venda de Cândido: libelo cível de devolução de escravo e ação de um comerciante no oeste paulista (1877), na coletânea Escravidão, mestiçagens, populações e identidades culturais, organizada por Eduardo Paiva, Isnara P. Ivo e Ilton César Martins (Annablume, 2010).

\section{Vitor Hugo Bastos Cardoso}

Licenciado e bacharel em História, cursa o Mestrado em História na Universidade Federal de Santa Catarina. Tem se dedicado a revisitar o período colonial de Santa Catarina à luz das novas historiografias portuguesa e brasileira, concentrando-se nas redes familiares e mercantis. 
Este livro foi editorado com as fontes Chaparral Pro e Din. Publicado on-line em: editora.ufsc.br/estante-aberta 
A história de Santa Catarina valoriza muito a presença europeia, e Florianópolis é conhecida como terra de tradições açorianas. Este livro traz elementos para uma outra história da cidade, que incorpora a presença de africanos e afrodescendentes. Tratase de uma história diversa, em vários sentidos: porque é diferente daquela contada até agora, porque é múltipla e porque está mudada. Diversa, ainda, porque é discordante. 